UNIVERSIDADE DE SÃO PAULO

INSTITUTO DE PSICOLOGIA

DEPARTAMENTO DE PSICOLOGIA CLÍNICA

PSICOTERAPIA ANALÍTICO-COMPORTAMENTAL COM ADOLESCENTES

INFRATORES DE ALTO-RISCO: MODIFICAÇÃO DE PADRÕES

ANTI-SOCIAIS E DIMINUIÇÃO DA REINCIDÊNCIA CRIMINAL

Giovana Veloso Munhoz da Rocha 
UNIVERSIDADE DE SÃO PAULO

INSTITUTO DE PSICOLOGIA

DEPARTAMENTO DE PSICOLOGIA CLÍNICA

PSICOTERAPIA ANALÍTICO-COMPORTAMENTAL COM ADOLESCENTES

INFRATORES DE ALTO-RISCO: MODIFICAÇÃO DE PADRÕES

ANTI-SOCIAIS E DIMINUIÇÃO DA REINCIDÊNCIA CRIMINAL

Giovana Veloso Munhoz da Rocha

Sônia Beatriz Meyer

Tese apresentada ao Instituto de Psicologia da Universidade de São Paulo como requisito para obtenção do grau de Doutoramento em Psicologia Clínica.

Orientadora: Profa. Dra. Sonia Beatriz Meyer

São Paulo, SP

2008 
Catalogação na publicação

Serviço de Biblioteca e Documentação

Instituto de Psicologia da Universidade de São Paulo

Rocha, Giovana Veloso Munhoz da.

Psicoterapia analítico-comportamental com adolescentes infratores de alto-risco: modificação de padrões anti-sociais e diminuição da reincidência criminal / Giovana Veloso Munhoz da Rocha; orientadora Sonia Beatriz Meyer. -- São Paulo, 2008.

$300 \mathrm{p}$.

Tese (Doutorado - Programa de Pós-Graduação em Psicologia. Área de Concentração: Psicologia Clínica) - Instituto de Psicologia da Universidade de São Paulo.

1. Terapia comportamental 2. Análise do comportamento 3. Comportamento anti-social 4. Processos terapêuticos 5. Delinqüência juvenil I. Título.

RC489.B4 


\author{
UNIVERSIDADE DE SÃO PAULO \\ INSTITUTO DE PSICOLOGIA \\ DEPARTAMENTO DE PSICOLOGIA CLÍNICA
}

\title{
PSICOTERAPIA ANALÍTICO-COMPORTAMENTAL COM ADOLESCENTES INFRATORES DE ALTO-RISCO: MODIFICAÇÃO DE PADRÕES ANTI-SOCIAIS E DIMINUIÇÃO DA REINCIDÊNCIA CRIMINAL
}

Candidata: Giovana Veloso Munhoz da Rocha

Data da Defesa:

Resultado:

Banca Examinadora:

$\overline{\text { Profa. Dra. Sonia Beatriz Meyer (USP), Orientadora. }}$

Prof. Dra. Paula Inez Cunha Gomide (FEPAR), Membro.

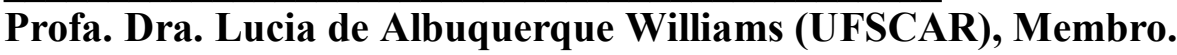

Prof. Dr. Antonio de Pádua Serafim (FMUSP, IPq-HCFMUSP, Faculdade de Psicologia da Universidade Camilo Castelo Branco, International Academy of Law and Mental Health - Canadá ), Membro.

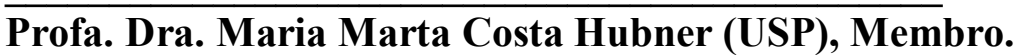


"Perdoem a cara amarrada Perdoem a falta de abraço Perdoem a falta de espaço Os dias eram assim

Perdoem por tantos perigos Perdoem a falta de abrigo Perdoem a falta de amigos Os dias eram assim

Perdoem a falta de folhas Perdoem a falta de ar Perdoem a falta de escolha Os dias eram assim

E quando passarem a limpo E quando cortarem os laços E quando soltarem os cintos Façam a festa por mim

Quando lavarem a mágoa Quando lavarem a alma Quando lavarem a água Lavem os olhos por mim

Quando brotarem as flores Quando crescerem as matas Quando colherem os frutos Digam o gosto pra mim"

(aos nossos filhos - ivan lins e vitor martins)

Aos meninos, obrigada. 


\section{Agradecimentos}

Agradeço, contudo sem encontrar palavras que possam expressar a extensão de minha gratidão, à minha orientadora Professora Doutora Sonia Beatriz Meyer, cuja sabedoria e conhecimento, generosidade e inestimável carinho e tranquilidade tornaram não só possível, mas gratificante, este longo processo de realização profissional e pessoal.

"O mundo é um lugar perigoso de se viver, Não por causa daqueles que fazem o mal, mas sim por causa daqueles que observam e deixam o mal acontecer." (Albert Eisnten) Para Doutora Paula I. C. Gomide: Não existem palavras para lhe agradecer por ter acreditado, confiado, compartilhado e investido neste trabalho como se também fosse seu (e em parte o é, pois sem a oportunidade que me foi ofertada por você, ele não teria acontecido). É muito bom aprender com você.

Sou grata também por todo incentivo, amizade e conhecimento que venho recebendo ao longo de aproximadamente dez anos, de minhas grandes e preciosas amigas, professoras e supervisoras: Roseli Hauer, Yara Kuperstein, Maria da Graça Saldanha Padilha e Denise Heller.

Muito obrigada à amiga Ângela de Loyola e Silva Runnacles pelo suporte que foi determinante para meu ingresso no doutorado, e à amiga Giovana Del Prette pela preciosa companhia na etapa inicial e também mais cansativa deste processo e pela contribuição na formatação do título da tese.

Agradeço aos meus amigos Carolina Sicuro e Adriano Watanabe (e especialmente a seus pais, irmãos e tia), companheiros de estrada, de kombi, de princípio de rebelião, de agonia, de dor, de tristeza, de indignação, de desabafo, e de tudo de bom que vinha depois disso.

Meus agradecimentos vão também para meu alunos, estagiários e voluntários de pesquisa, sem os quais não teria sido possível completar este trabalho: Evelise Galvão de Carvalho, Mariana Moro Ramires, Inoili M. Fortunati, Ligia Gouveia, Rima Awada Zahra, Ana Carla Marcon, Liz T. Hartof, Poliana Rodrigues, Ana Paula Senna, Fernanda Silva, Juliane Muniz, Michele Gouveia, Mariana Ricetti, Luana France, Marcelo Rocha, Ana Claudia Blanchet, Aline Ribeiro Foltran, Andressa Linhares, Fabiele Mentz, Priscila Martins, Paulo Henrique Azevedo Grande e Izabel do Rocio Silva.

Agradeço aos membros da banca Dra. Lucia Williams, Dra. Martha Hubner, Dra. Paula Gomide e Dr. Antonio Serafim, por aceitarem compartilhar seus conhecimentos avaliando este trabalho.

mãe e pai, sempre presentes. Muito obrigada.

... agradecida, sem palavras... 
Rocha, G. V. M. (2008) Psicoterapia analítico-comportamental com adolescentes infratores de alto-risco: modificação de padrões anti-sociais e diminuição da reincidência criminal. Tese de Doutorado, Programa de Pós-graduação em Psicologia Clínica, Universidade de São Paulo.

\section{Resumo}

O presente estudo objetivou verificar se intervenções terapêuticas analíticocomportamentais com adolescentes infratores de alto-risco estariam relacionadas à diminuição dos comportamentos indesejáveis de hostilidade, mentir e culpar o outro e ao aumento de comportamentos adequados de auto-revelação, expressão de sentimentos positivos e expressão de arrependimento. Visou também identificar as intervenções mais utilizadas pelo psicoterapeuta e verificar se as mudanças estariam relacionadas à diminuição da reincidência criminal, permanência na escola, manutenção do trabalho e promoção de auto-sustento. Participaram deste estudo 11 adolescentes infratores internos de uma unidade do estado do Paraná, considerados infratores de alto risco por terem cometido delitos considerados graves. O Inventário de Estilos Parentais foi utilizado para caracterização dos participantes de acordo com as práticas educativas. Para análise das sessões de psicoterapia foi utilizado um instrumento baseado na observação clínica do terapeuta para avaliar mudanças comportamentais do cliente, e um instrumento formado por categorias de comportamentos do terapeuta para conhecer as intervenções do profissional. Após o desinternamento foram coletadas medidas comportamentais sobre a permanência na escola, manutenção do trabalho, manutenção da psicoterapia, promoção de auto-sustento e a não reincidência criminal. Os resultados gerais provenientes da análise de 99 dos atendimentos da mesma psicoterapeuta com 11 diferentes clientes indicaram que a média geral dos comportamentos mais utilizados pelo terapeuta ao longo das sessões foram: solicitar relato $(\bar{x}=40)$, informação $(\bar{x}=24)$, facilitação $(\bar{x}=19)$ e empatia $(\bar{x}=17)$. Os menos utilizados foram reprovação $(\bar{x}=3)$, aprovação $(\bar{x}=4)$ e recomendação $(\bar{x}=6)$. Em nove dos onze casos houve aumento de comportamentos adequados e diminuição de inadequados no repertório comportamental dos adolescentes. Nos dois casos onde esta mudança não ocorreu foi diagnosticado ao longo do processo a existência de transtorno de personalidade anti-social com características psicopáticas. Considerando-se os critérios de reinserção social obtidos no acompanhamento dos casos após desinternamento tem-se que: quatro adolescentes continuaram estudando, um parou temporariamente e retomou, dois continuam estudando no internamento e três não continuaram estudando; quanto à manutenção de trabalho seis participantes estavam no mercado informal, como autônomos, três tinham emprego formal e dois não trabalhavam. Quanto ao auto-sustento foi possível verificar que cinco o tinham alcançado, quatro o tinham parcialmente e ainda necessitavam de ajuda de outros e dois não o tinham. Quanto à continuidade em psicoterapia, dadas as dificuldades de mudança de cidade apenas três delas continuaram nos moldes formais, mas dos onze adolescentes só três cessaram contato com a psicoterapeuta e dois que ainda estavam internados manifestaram desejo de continuidade após o desinternamento.

Palavras-chave: Terapia comportamental, Análise do comportamento, Comportamento anti-social, Processos terapêuticos, Delinqüência juvenil 
Rocha, G. V. M. (2008) Behavior-Analytic Psychotherapy with high-risk juvenile offenders: antisocial patterns modification and criminal recidivism decrease. Doctoral Thesis, Clinical Psychology Postgraduation Program, Universidade de São Paulo, São Paulo, Brazil.

\begin{abstract}
This study aimed to verify whether behavioral analytic therapeutic intervention with high-risk juvenile offenders would be related to the decrease of undesirable behaviors such as hostility, lying, and blaming others, as well as the increase of desirable behaviors like self-disclosure, expression of positive feelings, and regrets. It also aimed to identify which interventions the psychotherapist used, and verify whether changes were related to the following measures of social reintegration: decrease in criminal recidivism, remaining at school, job maintenance, and self-sustenance. Participants were 11 adolescent offenders who were incarcerated in a state facility and considered high-risk offenders due to serious offenses. Parental Styles Inventory was used to classify participants according to parental educational practices. For analysis of psychotherapy sessions, a tool based on clinical observation by the therapist was used to evaluate clients' behavioral changes as well as a tool consisting of therapist's behavior categories for identifying professional interventions. After participants' release, data were collected concerning the above indicators of social reintegration. Results showed that the most frequent behaviors of the therapist across 99 of the sessions with 11 different clients-offenders were: obtaining information $(\bar{x}=40)$, giving information $(\bar{x}=24)$, facilitation $(\bar{x}=19)$ and empathy $(\bar{x}=17)$. The less used were disapproval $(\bar{x}=3)$, approval $(\bar{x}=4)$ and recommendation $(\bar{x}=6)$. In nine of the eleven cases there was an improvement of the desired behaviors and decline of the undesired in the adolescents' behavioral repertory. In two cases in which these changes didn't occur, the presence of antisocial personality disorder with psychopathic traces was diagnosed. Considering the community reintegration criteria obtained during follow-up, it was possible to note that: four boys continued studying, one stopped temporarily and returned later, two remained studying in the facility and three dropped out. Regarding job maintenance, six participants worked without formal registration, three were employed and two were not working at all. Five participants reached self-sustenance, four reached it partially, and still needed family help, and two were unsuccessful. Due to difficulties of geographical nature, only three participants continued formal psychotherapy. Two that were still interned expressed desire to continue after release and only three did not continue contact with the psychotherapist.
\end{abstract}

Key words: Behavior analysis, antisocial behavior, treatments, juvenile delinquents. 


\section{SUMÁRIO}

$\begin{array}{lll}\text { Resumo VII } & \text { VII }\end{array}$

\begin{tabular}{ll}
\hline Abstract & VIII
\end{tabular}

ÍNDICES

Índice de Tabelas $\quad$ X

$\begin{array}{lll}\text { Índice de Figuras } & \mathbf{X I}\end{array}$

Índice de Anexos _ XII

$\begin{array}{ll}\text { APRESENTAÇÃO } & 13\end{array}$

$\begin{array}{ll}\text { INTRODUÇÃO } & 17\end{array}$

$\begin{array}{ll}\mathrm{O} \text { adolescente infrator } & 17\end{array}$

$\begin{array}{ll}\text { Práticas educativas parentais e comportamento anti-social } & \mathbf{2 4}\end{array}$

Unidades de internação para adolescentes em conflito com a lei $\mathbf{3 8}$

Tratamento de comportamento anti-social e infrator $4 \mathbf{4 3}$

Psicoterapia Analítico-comportamental com Adolescentes Infratores $\mathbf{5 1}$

$\begin{array}{ll}\text { Vergonha e Culpa } & 69\end{array}$

$\begin{array}{ll}\text { Mentira } & \mathbf{7 6}\end{array}$

$\begin{array}{lc}\text { Aplicação das Práticas Educativas na Sessão Terapêutica } & \mathbf{8 0}\end{array}$

$\begin{array}{ll}\text { Programa para Adolescentes Infratores de Alto-risco } & \mathbf{8 5}\end{array}$

$\begin{array}{ll}\text { MÉTODO } & 97\end{array}$

$\begin{array}{lr}\text { Participantes } & 97\end{array}$

$\begin{array}{lr}\text { Instrumentos } & 99\end{array}$

$\begin{array}{ll}\text { Procedimento } & 111\end{array}$

$\begin{array}{ll}\text { RESULTADOS E DISCUSSÃO } & 117\end{array}$

Análise Geral do Processo 118

S1: O Bonzinho 126

S2: O Protegido 134

S3: O Malandro $\quad 145$

S4: O Menino e "Snyrf", O Rato

S5: O Solitário 164

S6: O Rejeitado $\quad 170$

S7: O Reclamão 177

S8: O Ator $\quad 185$

S9: O Gladiador $\quad 196$

S10: O Rebelde $\quad 202$

S11: O Líder 211

Resultados dos Indicadores Gerais de Modificação de Padrão Anti-social $\quad 235$

\begin{tabular}{lc}
\hline CONSIDERAÇÕES FINAIS & 240
\end{tabular}

REFERÊNCIAS 244

ANEXOS 259 


\section{ÍNDICES}

\section{Índice de Tabelas}

$\begin{array}{ll}\text { TABELA 1. Participantes do estudo } & 97\end{array}$

TABELA 2. Interpretação dos resultados do IEP $\quad 100$

TABELA 3. Dados normativos indicativos de risco de acordo com cada prática 101 educativa

TABELA 4. Sistema de categorias de registro das verbalizações do terapeuta.

TABELA 5. Práticas Educativas dos Cuidadores de S1 avaliadas através do Inventário 133 de Estilos de Estilos Parentais

TABELA 6. Práticas Educativas dos Cuidadores de S2 avaliadas através do Inventário 142

de Estilos de Estilos Parentais

TABELA 7. Práticas Educativas dos Cuidadores de S3 avaliadas através do Inventário 153

de Estilos de Estilos Parentais

TABELA 8. Práticas Educativas dos Cuidadores de S4 avaliadas através do Inventário 160

de Estilos de Estilos Parentais

TABELA 9. Práticas Educativas dos Cuidadores de S5 avaliadas através do Inventário 169 de Estilos de Estilos Parentais

TABELA 10. Práticas Educativas dos Cuidadores de S6 avaliadas através do 176 Inventário de Estilos de Estilos Parentais

TABELA 11. Práticas Educativas dos Cuidadores de S7 avaliadas através do 183 Inventário de Estilos de Estilos Parentais

TABELA 12. Pontuação da Escala PCL-R de S8

TABELA 13. Práticas Educativas dos Cuidadores de S8 avaliadas através do 194 Inventário de Estilos de Estilos Parentais

TABELA 14. Práticas Educativas dos Cuidadores de S9 avaliadas através do 201 Inventário de Estilos de Estilos Parentais

TABELA 15. Práticas Educativas dos Cuidadores de S10 avaliadas através do 209 Inventário de Estilos de Estilos Parentais

TABELA 16. Práticas Educativas dos Cuidadores de S11 avaliadas através do 227 Inventário de Estilos de Estilos Parentais

TABELA 17. Indicadores de modificação do comportamento infrator 


\section{Índice de Figuras}

Figura 1. Média Geral dos comportamentos do terapeuta. $\quad 119$

Figura 2. Sessões de psicoterapia analisadas do participante S1. 128

Figura 3. Média dos comportamentos inadequados e adequados de $\mathrm{S} 1$ ao longo das $\mathbf{1 3 0}$ sessões.

Figura 4. Média dos comportamentos do terapeuta por sessão no caso S1. 131

Figura 5. Sessões de psicoterapia analisadas do participante S2.

Figura 6. Média dos comportamentos inadequados e adequados de S2 ao longo das $\mathbf{1 3 5}$ sessões.

Figura 7. Média dos comportamentos do terapeuta por sessão no caso S2. 137

Figura 8. Carta de S2 ao padrinho do programa de egressos em abril de 2006.

Figura 9. Carta entregue à terapeuta algumas semanas antes do desinternamento de 141

S2.

Figura 10. Sessões de psicoterapia analisadas do participante S3. 146

Figura 11. Média dos comportamentos inadequados e adequados de S3 ao longo das 146 sessões.

Figura 12. Empatia do terapeuta ao longo das sessões de S3. 147

Figura 13. Média dos comportamentos do terapeuta por sessão no caso S3. $\quad 148$

Figura 14. Registros Diários dos Comportamentos Inadequados de S3. 153

Figura 15. Sessões de psicoterapia analisadas do participante S4. 156

Figura 16. Média dos comportamentos inadequados e adequados de S4 ao longo das 157 sessões.

Figura 17. Média dos comportamentos do terapeuta por sessão no caso S4. 158

Figura 18. Sessões de psicoterapia analisadas do participante S5. 166

Figura 19. Média dos comportamentos inadequados e adequados de S5 ao longo das 166 sessões.

Figura 20. Média dos comportamentos do terapeuta por sessão no caso S5. 167

Figura 21. Sessões de psicoterapia analisadas do participante S6 172

Figura 22. Média dos comportamentos inadequados e adequados de S6 ao longo das 172 sessões.

Figura 23. Média dos comportamentos do terapeuta por sessão no caso S6. 173

Figura 24. Avaliação diária de comportamentos inadequados de S6. 177

Figura 25. Sessões de psicoterapia analisadas do participante S7.

Figura 26. Média dos comportamentos inadequados e adequados de S7 ao longo das $\mathbf{1 8 0}$ sessões.

Figura 27. Média dos comportamentos do terapeuta por sessão no caso S7. $\quad 180$

Figura 28. Registros diários de comportamentos inadequados de S7. 184

Figura 29. Sessões de psicoterapia analisadas do participante S8. $\quad 187$

Figura 30. Média dos comportamentos inadequados e adequados de S8 ao longo das 188 sessões.

Figura 31. Média dos comportamentos do terapeuta por sessão no caso S8. 188

$\begin{array}{ll}\text { Figura 32. Bilhete de S8 para a terapeuta. } & 192\end{array}$

Figura 33. Carta de Natal de S8 para a terapeuta. $\quad 192$

Figura 34. Homenagem de Natal de S8 para todas as mulheres da unidade. 193

Figura 35. Sessões de psicoterapia analisadas do participante S9. 198

Figura 36. Média dos comportamentos inadequados e adequados de S9 ao longo das 198 sessões.

Figura 37. Média dos comportamentos do terapeuta por sessão no caso S9. 199

Figura 38. Sessões de psicoterapia analisadas do participante S10. 204

Figura 39. Média dos comportamentos inadequados e adequados de S10 ao longo 205 das sessões.

Figura 40. Média dos comportamentos do terapeuta por sessão no caso S10. 205

Figura 41. Sessões de psicoterapia analisadas do participante S11. 227

Figura 42. Práticas parentais da mãe e do padrasto. $\quad 228$

Figura 43. Médias dos comportamentos indesejáveis e médias dos comportamentos 230 desejáveis do cliente.

Figura 44. Comportamentos indesejáveis do cliente ao longo das sessões. 231

Figura 45. Comportamentos desejáveis do cliente ao longo das sessões. 231

Figura 46. Porcentagem por categoria de comportamento do terapeuta. 232 


\section{Índice de Anexos}

Anexo 1. Atividades de Escolarização

Anexo 2. Atividades do Programa para adolescentes infratores de alto-risco

Anexo 4. Termo de Consentimento Livre e Esclarecido

Anexo 5.Avaliação de Comportamentos Inadequados

Anexo 6. Instrumento para avaliação de comportamentos do terapeuta: 278 sistema de categorias de registro das verbalizações do terapeuta adaptado do Sistema Multidimensional de categorização de comportamentos da relação terapêutica de Zamignani (2007). 


\section{PSICOTERAPIA ANALÍTICO-COMPORTAMENTAL COM ADOLESCENTES \\ INFRATORES DE ALTO-RISCO: MODIFICAÇÃO DE PADRÕES ANTI- SOCIAIS E DIMINUIÇÃO DA REINCIDÊNCIA CRIMINAL}

\section{APRESENTAÇÃO}

Devido a uma rebelião que aconteceu em um dos maiores educandários do sul do país em setembro de 2004, o Governo do Estado do Paraná, responsável pelas unidades de internamento para cumprimento de medidas sócio-educativas, contratou a psicóloga, docente e pesquisadora Paula Inez Cunha Gomide para apresentar uma nova proposta de tratamento para adolescentes infratores que se mostrasse mais efetiva, principalmente através da redução do número de rebeliões nas unidades de tratamento.

Foi apresentada ao governo uma proposta inédita de uma unidade para o internamento apenas dos adolescentes considerados de alto-risco levando-se em conta a gravidade da infração cometida, comportamentos de liderança negativa dentro das instituições e reincidência. Ou seja, a proposta foi a de reunir adolescentes considerados "irrecuperáveis" em uma mesma unidade, com alojamentos individuais e tratamento personalizado. Esta Unidade-piloto teria como objetivo testar um procedimento em caráter científico, para que verificada sua efetividade, o programa ali implementado pudesse ser descrito e reproduzido em outras instituições.

Aprovada a proposta da pesquisadora, foi reformado um prédio em um complexo penitenciário, ficando este isolado de qualquer outra unidade, e em fevereiro de 2005, 17 jovens infratores passaram a fazer parte deste programa individualizado de recuperação.

O Programa foi composto por atividades básicas, incluindo a escolarização (Anexo 1), pelas quais todos os internos deveriam passar antes de serem 
encaminhados para as atividades terapêuticas. As atividades educativas (Anexo 2) eram todas aquelas que pudessem proporcionar aprendizagem de repertórios necessários à reinserção social do adolescente. Estas atividades consistiam em psicoterapia individual, treino em comportamento moral, treino em habilidades sociais, atividades externas com objetivos terapêuticos (treinar habilidades sociais, etc.) e atendimento a drogaditos. A psicoterapia individual era realizada por voluntárias, com formação em análise do comportamento, na própria unidade no início do internamento e podia se prolongar ao consultório da psicóloga caso o adolescente assim desejasse quando desinternado. Os grupos de comportamento moral e habilidades sociais aconteciam na unidade, com no máximo três adolescentes e as sessões eram semi-estruturadas. Temas específicos deveriam ser trabalhados durantes os encontros e as variações poderiam ocorrer dependendo dos comportamentos que surgissem nas atividades. Nas atividades de comportamento moral o foco eram virtudes tais como: honestidade, justiça, amizade e coragem. No grupo de habilidades sociais trabalhavam-se resolução de problemas, empatia, assertividade, dentre outras. Só iniciava a participação nos grupos o adolescente que já estivesse participando da psicoterapia. Durante o processo de atendimento em grupo o adolescente era avaliado para que pudesse passar à fase das atividades de qualificação profissional ${ }^{1}$ através de cursos profissionalizantes dentro ou fora da unidade, estágios, etc, que precediam seu desinternamento.

Todo o Programa baseava-se em um consistente conjunto de procedimentos de segurança (Anexo 3) e de uma avaliação diária (Anexo 5), individual, de comportamentos inadequados e adequados do adolescente. Os procedimentos de

\footnotetext{
1 A qualificação profissional era feita prioritariamente fora da unidade e passava a fazer parte do cotidiano do adolescente quando as avaliações da equipe técnica e da psicoterapia apontam para a existência de comportamentos necessários a esta atividade. Podiam acontecer na própria unidade através de atividades de trabalho, gradativas, à medida que o adolescente mostrasse responsabilidade e comprometimento com as demais tarefas (ter cumprido em tempo as tarefas iniciais, mostrar-se educado com a equipe. Exemplo: cortar grama, limpar o tanque) $\mathrm{O}$ ingresso em cursos de qualificação profissional fora da unidade se dava na etapa final do internamento, antecedendo o desinternamento.
} 
segurança descreviam a conduta que deveria ser adotada por todas as pessoas que freqüentassem a unidade, bem como as sanções disciplinares cabíveis aos comportamentos inapropriados dos adolescentes, como aplicá-las e quem deveria ou poderia fazê-lo. Já as avaliações diárias de comportamento dos adolescentes eram constituídas por comportamentos abertos que poderiam ser observados por quaisquer profissionais na unidade, como, por exemplo, atirar objetos no educador, cuspir em alguém, ameaçar com palavras (inadequados) e dizer por favor, agradecer, cumprimentar (adequados).

Foi então que, conhecendo meu desejo de trabalhar com casos considerados difíceis, refratários e resistentes à psicoterapia, a doutora Paula Gomide convidou-me a integrar o programa como psicoterapeuta voluntária.

Com pouco conhecimento sobre a clientela, local onde estavam e até mesmo sobre a gravidade dos crimes que cometeram, fui até o local para conhecer as condições de trabalho, que segundo a doutora Paula, eram no mínimo precárias. Naquele dia fui apresentada a quatro adolescentes e em seguida realizei o primeiro atendimento dos mesmos.

Apesar da violência e abuso cometidos por crianças e adolescentes terem cada vez mais espaço na mídia, o contato direto com os agentes de atos infracionais violentos e abusivos mostrou ser uma experiência impactante e reveladora, que possibilitou o vislumbre do complexo sistema coercitivo que favorece a existência dos horrores relatados e vividos por estes jovens.

Durante um ano e meio trabalhei como psicoterapeuta voluntária, atendendo 11 adolescentes, alguns membros familiares, dentro e fora da unidade. Em fevereiro de 2006 fui convidada a exercer a função de diretora da unidade, substituindo a Dra. Paula Gomide, que havia dirigido a unidade até então. Acumulei a função de 
psicoterapeuta (dos adolescentes que já estavam em atendimento) e diretora da unidade por um ano, quando pedi meu afastamento do IASP (Instituto de Assistência Social do Paraná) juntamente com a Dra. Paula Gomide. Nosso afastamento das funções que exercíamos, coordenadora do programa e diretora da unidade, deveu-se às dificuldades instransponíveis entre nosso trabalho e a política da direção do IASP, que atualmente se chama Secretaria de Estado da Criança e da Juventude. 


\section{INTRODUÇÃO}

\section{O Adolescente Infrator}

O adolescente infrator, via de regra, é oriundo de ambientes altamente coercitivos, nos quais a violência física e o abandono são constantes. Desta forma, acabam por reproduzir em sua relação com o mundo um padrão de comportamento conhecido como anti-social. O comportamento anti-social pode ser definido como aquele que viola e desrespeita os direitos alheios, ou seja, aquele que a todo custo busca beneficiar-se, desconsiderando os possíveis danos que isso possa causar a outrem.(Kazdin e Buela-Casal, 1998)

De acordo com a Constituição da República Federativa do Brasil (1988) - Art.227. "É dever da família e do Estado assegurar à criança e ao adolescente, com absoluta prioridade, o direito à vida, à saúde, à alimentação, à educação, ao lazer, à profissionalização, à cultura, à dignidade, ao respeito, à liberdade e à convivência familiar e comunitária, além de colocá-los a salvo de toda forma de negligência, discriminação, exploração, violência, crueldade e opressão".

Porém, na prática, programas que deveriam constituir-se em instrumentos de promoção da saúde, da educação, da alimentação e da convivência familiar parecem não contribuir para que diminua o número de crianças que passam o dia nas ruas ao invés da escola, o que se relaciona às crescentes estatísticas da delinqüência juvenil.

Conhecendo este panorama e a demanda específica das unidades de internamento a Dra. Paula Gomide delineou um programa especifico para os adolescentes infratores. Durante as atividades iniciais do programa para adolescentes infratores de alto-risco da Doutora Paula Gomide foi possível observar que quando estas se davam em grupos, mesmo que pequenos, eram mais difíceis de serem conduzidos em 
termos da manutenção do objetivo da atividade e do cumprimento dos critérios de segurança. Também se observava após as atividades em grupo o fortalecimento de lideranças anti-sociais e o aumento de alguns comportamentos agressivos nos adolescentes. Isto pode ser explicado pelo conceito de "treino anti-social".

O processo chamado de treino anti-social acontece em diversos níveis. Inicialmente ocorre em casa, com os pais e familiares, como descrito por Patterson, Reid e Dishion, (1992). Uma vez instalado no repertório da criança ou do adolescente o comportamento anti-social é um fator predominante no afastamento do indivíduo de grupos não-desviantes e um fator de fortalecimento de seu vínculo com os pares desviantes.

Os pares desviantes podem constituir a principal fonte de treino antisocial, pois proporcionam "atitudes, motivações e racionalizações" (Jolivette, 2002) que favorecem e apóiam o comportamento anti-social, além de fornecer oportunidades de engajamento em atos infracionais específicos. Crianças que se associam com grupos de pares desviantes adentram este processo de especialização desviante, no qual os pares ensinam as normas e valores anti-sociais. Esta relação, segundo Christle, Nelson e Jolivette, (2002) tende a se fortalecer ao longo dos anos e os padrões anti-sociais solidificam-se, tornando-se mais resistentes à modificação. Patterson, DeBaryshe e Ramsey (1989) citam um estudo realizado em uma instituição correcional que demonstrou que os pares infratores provêem reforço positivo considerável para o comportamento desviante, bem como punem comportamentos socialmente aceitos.

Segundo Patterson, Reid e Dishion (1992) demonstrações de comportamento anti-social podem acontecer desde os dois anos de idade, quando as crianças são consideradas de temperamento difícil, forte, com tendência a destruir objetos e agredir seus cuidadores. Pesquisas apontam que este padrão de 
comportamento desobediente, impulsivo, socialmente inadequado e impaciente tende para o estabelecimento do chamado Transtorno Desafiador de Oposição (Capaldi, Chamberlain \& Patterson, 1997; Reppold, Pacheco \& Hutz, 2005), que por sua vez, quando persistente facilita a exclusão do grupo de iguais na adolescência que é um dos critérios diagnósticos para o transtorno de conduta na adolescência e anti-social na vida adulta.

Quando uma conduta recorrente de comportamento negativista, desafiador, desobediente e hostil para com figuras de autoridade, se manifesta antes dos 8 anos de idade é possível que esteja presente o Transtorno Desafiador de Oposição (DSM IV-TR, 2002). Os comportamentos opositivos freqüentemente aparecem em casa, mas também tendem a se manifestar na escola e em outras situações.

Segundo o manual de critérios diagnósticos DSM IV-TR (2002) o transtorno se caracteriza pela ocorrência usual de pelo menos quatro dos seguintes comportamentos: perder a paciência, discutir com adultos, desafiar ativamente ou recusar-se a obedecer a solicitações ou regras dos adultos, deliberadamente fazer coisas que aborrecem outras pessoas, responsabilizar outras pessoas por seus próprios erros ou mau comportamento, ser suscetível ou facilmente aborrecido pelos outros, mostrar-se enraivecido e ressentido ou ser rancoroso ou vingativo. Estes comportamentos devem ocorrer com mais freqüência do que se observa tipicamente em indivíduos de idade e nível de desenvolvimento comparáveis e deve acarretar prejuízo significativo no funcionamento social, acadêmico ou ocupacional. De acordo com o DSM IV-TR (2002):

A hostilidade pode ser dirigida a adultos ou a seus pares, sendo demonstrada ao incomodar deliberadamente ou agredir verbalmente outras pessoas (em geral sem a 
agressão física mais séria vista no Transtorno da Conduta).

As manifestações do transtorno estão quase que invariavelmente presentes no contexto doméstico, mas podem não ser evidentes na escola ou na comunidade (p.126).

De acordo com o DSM IV o Transtorno de Conduta (Código da Cid 10 F 91.8) pode iniciar já aos 5 ou 6 anos de idade, mas habitualmente aparece ao final da infância ou início da adolescência. O início após os 16 anos é raro. Tem como principal característica um padrão repetitivo e persistente de comportamento no qual são violados os direitos básicos dos outros ou normas ou regras sociais importantes apropriadas à idade. Esses comportamentos formam quatro agrupamentos principais: conduta agressiva que causa ou ameaça danos físicos a outras pessoas ou a animais, conduta não-agressiva que causa perdas ou danos a propriedades, defraudação ou furto e sérias violações de regras. Pode ser classificado ainda quanto ao início na infância ou na adolescência, e de intensidade leve, moderada ou severa.

Os jovens com Transtorno da Conduta geralmente apresentam pouca empatia e pouca ou nenhuma preocupação pelos sentimentos, desejos e bem-estar alheios. Justificam a própria agressividade com a suposta hostilidade que percebem nos outros. Podem não possuir sentimentos de culpa ou remorso e alguns aprendem que a expressão de culpa pode reduzir ou evitar punições. Este transtorno freqüentemente está associado com um início precoce de comportamento sexual, consumo de álcool, uso de substâncias ilícitas e atos arriscados. O uso de drogas ilícitas pode aumentar o risco de persistência do transtorno e os comportamentos daí advindos usualmente levam ao fracasso escolar, desemprego, problemas com a justiça, doenças sexualmente 
transmissíveis, gravidez não planejada e ferimentos por acidentes ou lutas corporais (DSM-IV - TR, 2002).

A predisposição ao transtorno pode estar ligada aos seguintes fatores, também descritos na literatura: rejeição e negligência parental, temperamento difícil no bebê, práticas inconsistentes de criação dos filhos com disciplina rígida, abuso físico ou sexual, falta de supervisão, institucionalização nos primeiros anos de vida, mudanças freqüentes dos responsáveis pela criança, família muito numerosa, associação com um grupo de companheiros delinqüentes e certos tipos de psicopatologias em parentes próximos. Os comportamentos típicos do transtorno variam com a idade, à medida que o indivíduo desenvolve maior força física, capacidades cognitivas e maturidade sexual. Ainda segundo o DSM IV - TR (2002):

Comportamentos menos severos (por ex., mentir, furtar em lojas, entrar em lutas corporais) tendem a emergir primeiro, enquanto outros (por ex., roubo) tendem a manifestar-se mais tarde. Entretanto, existem amplas diferenças entre os indivíduos, sendo que alguns se envolvem em comportamentos mais prejudiciais em uma idade precoce (p.123).

O comportamento anti-social, característica do adolescente infrator, é explicado através de diversas abordagens da psicologia e de outras ciências humanas. Um dos modelos explicativos mais divulgados e aceitos na comunidade científica norte americana é o chamado Modelo de Estágios Sócio-interacionista, de Patterson e colegas (1992). O modelo busca descrever o desenvolvimento de comportamento anti-social em quatro estágios, estando na base o ambiente familiar, passando pelo fracasso escolar, associação com pares desviantes e chegando ao encarceramento. 
Este modelo também é conhecido como “A Erva Daninha”. O primeiro e fundamental estágio descreve os elementos-base sobre os quais se fundamentará o desenvolvimento do comportamento anti-social. Este "substrato" é composto por (1) características da família (uso e abuso de substâncias, pouca ou nenhuma presença dos avós, pais ou avós anti-sociais), (2) por estressores sociais (pobreza, desemprego, vizinhança violenta) e (3) pelo temperamento abrasivo da criança (hiperatividade, oposição, insônia) em sua relação com (4) as práticas parentais ineficazes (gritos, surras, superproteção) relacionadas à (5) baixa auto-estima infantil e os primeiros sinais do comportamento anti-social. Nesta fase os pais já descrevem a criança como difícil e diferente dos irmãos e de outras crianças.

O segundo estágio é marcado por acontecimentos relacionados à escola, onde há o entrelaçamento dos seguintes fatores: rejeição pelos pares (pois a criança tem poucas habilidades sociais e baixo rendimento escolar), humor deprimido da criança (a criança fica desanimada, pois dificilmente algum comportamento dela é positivamente reforçado), fracasso escolar e rejeição dos professores e de seus pais (os pais confirmam nesta fase suas idéias negativas acerca da criança que já existiam no primeiro estágio). Aqui se evidenciam reclamações sobre a criança, apontada como pouco capaz de aprender e permanecer em sala de aula. É próprio dos grupos sociais a rejeição do fracassado, logo, a criança rejeitada busca grupos semelhantes que aceitem-na.

Formam-se então os grupos de pares desviantes. Este é o limite da passagem para o terceiro estágio, no qual a criança aprimora suas habilidades antisociais junto com seus pares, experimenta drogas e estabelece um padrão delinqüente de comportamento. Neste estágio costuma acontecer o rompimento com a família.

No quarto estágio observam-se adultos jovens que não possuem habilidades sociais mínimas e não conseguem manter empregos quando os alcançam e 
nem mantêm relacionamentos afetivos estáveis. Geralmente neste estágio se dá a experiência de encarceramento, que usualmente é uma possibilidade de refinamento do comportamento criminoso (Patterson et. al 1992), pois nas prisões acabam por serem constituídas verdadeiras escolas de crime.

Alguns fatores de risco para o desenvolvimento de problemas de comportamento como delinqüência ou distúrbio anti-social foram descritos por Patterson et. al (1992) na "Roda Causal" do comportamento anti-social. Segundo este modelo os fatores de risco são entendidos como variáveis que estão associadas a uma alta probabilidade de ocorrência de resultados negativos ou indesejáveis. Outros autores (Reppold, Pacheco, Bardagi \& Hutz, 2002) selecionaram quatro principais fatores de risco: (1) práticas parentais familiares negativas; (2) presença de problemas de comportamento durante a infância; (3) ocorrência de comportamento anti-social em algum membro da família e (4) abandono ou fracasso escolar. Estes fatores são explicados e explorados originalmente no modelo de Patterson et. al (1992), corroborando para sua validade.

Antes mesmo de engajar-se no comportamento anti-social propriamente dito, o adolescente exposto aos fatores de risco familiares e sociais, tem um outro fator de risco: o fato de não possuir repertório para completar as tarefas desta fase do desenvolvimento. É possível exemplificar tal situação imaginando que o adolescente que abandona a escola adota uma estratégia de fuga e não de enfrentamento das dificuldades, deixando de vivenciar situações que ampliariam seu repertório de resolução de problemas interpessoais, e de oportunidades como, por exemplo, escolher uma ocupação.

O desenvolvimento esperado contempla a vivência de relações interpessoais gratificantes, o aprimoramento das habilidades sociais, a capacidade de 
lidar com situações adversas e estressantes e a ausência de psicopatologias (Kazdin, 1993). Já o adolescente infrator é carente de relações significativas em termos de vínculo afetivo, não possui repertório socialmente habilidoso e tem baixa tolerância à frustração (Gomide, 1998; Kellerman, 2002).

É importante ressaltar que nem todo adolescente infrator encontra-se sob medida socioeducativa, muitos se encontram na sociedade entre as demais crianças e jovens; porém os dados estatísticos e descritivos desta população referem-se aos adolescentes privados de liberdade, em internação provisória ou em semiliberdade e é deles que trata este trabalho.

\section{Práticas educativas parentais e comportamento anti-social}

A fim de orientar os comportamentos dos filhos, cumprindo a tarefa de agentes de sua socialização, os pais utilizam estratégias denominadas práticas educativas parentais. Gomide (2003) afirma que as práticas educativas podem fomentar tanto comportamentos pró-sociais quanto anti-sociais, "dependendo da freqüência e intensidade que o casal parental utilize determinadas estratégias educativas” (p. 21).

As práticas parentais são específicas, direcionadas a um comportamentoalvo. Bater numa criança para que ela obedeça ou elogiá-la para fazer sentir-se bem são exemplos de práticas parentais (Fox \& Brenner, 1999). No modelo de Steinberg e Darling (1993), as práticas parentais têm um efeito direto sobre as respostas da criança.

Sete variáveis foram selecionadas a partir do modelo de estilos parentais de Gomide (2006), cinco delas que devem ser evitadas pelo psicoterapeuta e que estão relacionadas ao desenvolvimento do comportamento anti-social: negligência, abuso físico, disciplina relaxada, punição inconsistente e monitoria negativa; e duas que devem ser privilegiadas durante o processo terapêutico e que facilitam a aprendizagem do comportamento socialmente adequado: monitoria positiva e comportamento moral. 
Segundo Gomide (2006, p.9) a Monitoria Positiva "envolve o uso adequado da atenção e distribuição de privilégios, o adequado estabelecimento de regras, a distribuição contínua e segura do afeto, o acompanhamento e supervisão das atividades escolares e de lazer" e o Comportamento Moral "implica no desenvolvimento da empatia, do senso de justiça, da responsabilidade, do trabalho, da generosidade e do conhecimento do certo e do errado quanto a uso de drogas e álcool e sexo seguro sempre seguido de exemplo dos pais" e neste caso especificamente, do psicoterapeuta que serve como modelo para o adolescente. As Práticas Educativas Negativas compreendem:

Negligência, ausência de atenção e de afeto; o Abuso Físico e Psicológico, caracterizado pela disciplina através de práticas corporais negativas e ameaça e chantagem de abandono e de humilhação do filho; a Disciplina Relaxada que compreende o relaxamento das regras estabelecidas; a Punição Inconsistente onde os pais se orientam pelo seu humor na hora de punir ou reforçar e não pelo ato praticado e a Monitoria Negativa caracterizada pelo excesso de instruções independentemente do seu cumprimento e conseqüentemente pela geração de um ambiente de convivência hostil (Gomide, 2006, p.8).

Comportamentos indicados pela literatura como de risco para o desenvolvimento de conduta infratora (agressividade, dificuldade escolar, problemas de relacionamento, rejeição social na infância), encontram solo fértil para se desenvolverem em famílias com pais que possuem dificuldade em manter a disciplina e em estabelecer e manter regras. Alguns teóricos descrevem variáveis do temperamento 
dos pais e das crianças que em interação dificultam a manutenção destas normas e limites, ou seja, o padrão comportamental da criança também interfere na maneira como os pais irão lidar com ela (Snyder \& Patterson, 1987; Kupersmidt, Coie \& Dodge, 1990; Patterson, Reid \& Dishion, 1992; Dodge, Pettit \& Battes, 1994).

O determinismo recíproco entre os comportamentos dos pais e do filho o comportamento parental afeta a criança, assim como o comportamento da criança provoca algumas respostas dos pais - descrito por Maccoby e Martin (1983) está diretamente relacionado às práticas parentais. As práticas parentais, por sua vez, podem ser determinadas por fatores tais como: satisfação conjugal, crenças acerca da disciplina, história de abuso parental, depressão parental, nível de suporte dado pelo cônjuge, idade e nível de escolaridade dos pais e situação econômica precária (Fox \& Brenner, 1999).

Costa et. al (2000) realizaram uma revisão de literatura através da qual perceberam vários estudos que demonstram a importante influência que o estilo parental tem sobre várias áreas do desenvolvimento psicossocial de crianças e adolescentes, dentre as quais o ajustamento social, a psicopatologia e desempenho escolar. Na mesma linha de pensamento, Marinho (2001) afirma que quanto menos conhecimento e habilidades os pais têm para educar seus filhos, mais eles utilizam disciplina severa e inconsistente, promovendo assim o aparecimento do comportamento anti-social.

Gomide $(2003,2004)$ parte do pressuposto de que o estilo parental é o resultado da confluência de forças das práticas educativas parentais, o que equivale dizer que em um estilo parental positivo as práticas educativas positivas prevalecem sobre as negativas. A autora selecionou sete variáveis para classificar as práticas educativas, dentre as quais cinco estão relacionadas ao comportamento anti-social: negligência, abuso físico, disciplina relaxada, punição inconsistente e monitoria 
negativa. O comportamento pró-social é promovido por duas delas: monitoria positiva e comportamento moral.

Empatia, justiça, generosidade, amizade, solidariedade, respeito são valores que transparecem através de práticas educativas, especialmente da monitoria positiva e do comportamento moral, e se correlacionam positivamente com o comportamento pró-social, menor vulnerabilidade ao uso de drogas, níveis elevados de raciocínio e comportamentos morais pró-sociais, segurança em relação ao próprio bemestar e habilidade empática da criança e do adolescente ( Hoffmann, 1994 apud Gomide, 2006; Nurco \& Lerner, 1996).

Um pobre julgamento moral foi encontrado por vários pesquisadores em um levantamento realizado por Gomide (2006), sob as seguintes condições: adolescentes infratores, não-escolarizados, criados em lares autoritários, dependentes de álcool e drogas (Bzuneck, 1979; Freitag, 1984; Menin, 1985; Araújo, 1999; Nurco \& Lerner, 1996). Panorama grave, tendo-se em vista que crianças que não vivenciaram modelos morais na própria família estão mais propensas a cometerem infrações na vida adulta, bem como não aprendem a ser solidários ou a sentir culpa quando cometem algum ato que prejudique o outro (Loos, Ferreira \& Vasconcelos, 1999; Hughes \& Dunn, 2000).

Cada prática educativa pode ser descrita separadamente de acordo com seus efeitos sobre o comportamento da criança. A punição inconsistente, por exemplo,interfere na percepção do indivíduo, prejudicando a sua avaliação no que se refere aos efeitos que suas ações têm sobre os outros e sobre o meio (Gomide, 1998). Quando a mãe pune a criança algumas vezes e outras não, pelo mesmo comportamento, o que está determinando sua conduta não é a ação da criança, mas sim seu estado emocional. Desta forma prejudica-se a aprendizagem de valores morais; a criança não 
aprende o que é certo ou errado, mas aprende a discriminar o humor parental. Passa a comportar-se de forma a evitar os "maus humores" dos pais, afastando-se até que o ambiente "melhore". Nesta caminhada, muitas vezes, procura grupos desviantes. A baixa auto-estima causada por esta prática educativa - na qual a criança é punida por algo independente de sua conduta - permite que ela seja mais facilmente conduzida a cometer atos criminosos, por estar fragilizada (Feldman, 1979).

Também a monitoria negativa, ou supervisão estressante, é uma prática educativa que precede a insegurança infantil relativa à baixa auto-estima. Outros efeitos comportamentais decorrentes desta prática educativa são: a não obediência, tendência de associar-se a pares anti-sociais, risco aumentado para a delinqüência (Patterson et al., 1992; Barber, 1996; Pettit, Laird, Dodge, Bates \& Criss, 2001), problemas externalizantes precoces (Pettit et al., 2001), conflitos sobre a autonomia do adolescente, comportamentos ansiosos e de medo excessivo. (Barber, 1996; Steinberg, 1990).

Práticas educativas parentais coercitivas utilizadas para monitorar e controlar os comportamentos dos filhos fazem com que crianças e adolescentes não aprendam sobre as conseqüências de seus comportamentos e se comportem de maneira inadequada na ausência do controle externo.

Não menos importante é o impacto negativo da negligência no desenvolvimento infantil. Crittenden (1985) descreve os pais negligentes como não responsivos e que se retiram das situações difíceis; as mães não aceitam suas responsabilidades e são limitadas em competências gerais. Ignoram a maioria dos comportamentos da criança e respondem muito pouco às iniciativas de comunicação das crianças. As crianças submetidas a esta prática são passivas e sofrem com déficits comportamentais. 
Os comportamentos anti-sociais juvenis são mais comumente observados em famílias com baixo nível de interação entre seus membros e um alto nível de negligência (Reppold, Pacheco \& Hutz, 2005). Segundo os autores, a família ao invés de proteger, acaba expondo emocionalmente seus filhos, destacando um padrão de interação inadequado que certamente será reproduzido.

A negligência inclui-se no conceito de maus-tratos amplamente divulgado pela mídia e veículos de comunicação em massa. O conceito atual de maustratos infantis inclui abuso físico, abuso psicológico, abuso sexual e negligência.

Gershoff (2002) apresentou cinco subitens para classificar maus-tratos: abuso físico, abuso sexual, negligência física (falha em fornecer cuidados básicos e ausência de supervisão), maus-tratos emocionais e maus-tratos morais, legais e educacionais. $O$ subitem de negligência pode incluir ainda negligência física, emocional, médica, de saúde mental e educacional. O mesmo autor faz uma distinção entre punição corporal e abuso físico. Define punição corporal como a utilização da força física intencionando provocar dor, mas não machucar ou ferir, com o propósito de corrigir ou controlar a criança. $\mathrm{O}$ abuso físico é definido como o resultado potencial da punição corporal, caracterizado pelo socar, espancar, chutar, morder, queimar, sacudir ou por simplesmente machucar a criança. Comportamentos que não machucam fisicamente, como as palmadas e tapas, são considerados punição corporal e comumente são administrados em crianças até cinco anos, com freqüência de uma ou duas vezes ao mês.

A punição corporal e o abuso físico são pontos em continuidade, sendo que se a punição for administrada muito severa ou freqüentemente ela atravessa a linha para o abuso físico. Os pais abusivos relatam que os incidentes abusivos começaram 
com punição corporal instrumental ${ }^{2}$. Os fatores precipitadores para a passagem da punição ao abuso podem ser o estresse, a falta de apoio e sustento, e hostilidade. Pais que administram punição corporal tendem a ser abusivos verbalmente com seus filhos, através de insultos, xingamentos e ameaças. Essa combinação pode promover o desenvolvimento da agressão, delinqüência e comportamento anti-social nas crianças. (Gomide, 2006)

Para Haapasotoa e Pokelaa (1998) práticas parentais violentas têm sido consideradas como fatores etiológicos de problemas sociais e psicológicos como comportamentos criminosos e distúrbios psiquiátricos em adultos. Espancamentos, atitudes autoritárias, disciplina severa, rejeição, falta de monitoria e supervisão, separação, divórcios, instabilidade, conflitos conjugais e características parentais de comportamentos desviantes tais como criminalidade, abuso de substâncias psicoativas são algumas das variáveis apontadas pelas pesquisas mais recentes. Isso demonstra que embora a violência seja causada por múltiplos fatores, sua trajetória normalmente é cíclica.

Strauss (1994) acredita que a violência em uma esfera da vida de uma pessoa pode desencadear violência em outras esferas, confirmando o que já foi postulado pelo senso comum: violência gera violência, muitas vezes em proporções crescentes. É a chamada transmissão intergeracional da violência

Moran, Vuchinich e Hall, (2004) em uma pesquisa que visava relacionar maus-tratos ao abuso de substâncias na adolescência encontraram através de seus resultados a sugestão de que todos os tipos de maus-tratos, incluindo abuso emocional, estão relacionados a níveis significativamente mais altos de abuso de substâncias e deveriam ser considerados sérios fatores de risco para o uso de substâncias durante a

\footnotetext{
${ }^{2}$ Gershoff (2002) classifica a punição em dois tipos: quando é planejada, controlada, e não acompanhada de emoções fortes por parte dos pais, é dita Instrumental e quando é derivada do momento, acompanhada de sentimentos de raiva e possivelmente de estar fora do controle, é chamada de Impulsiva.
} 
adolescência. Os resultados também indicaram que a força da associação entre maustratos e uso de substâncias varia de acordo com o tipo de maus-tratos. Jovens que experienciaram tanto abuso físico quanto sexual estão sob um risco especialmente maior de abuso de substâncias.

Em outro estudo sobre o mesmo tema Rodgers et al. (2004), consideram como maus-tratos o abuso físico, o abuso sexual, o abuso emocional, a negligência física e a negligência emocional, e concluem que quanto mais tipos de maus-tratos na infância os participantes relatavam, maior a probabilidade de que tivessem problemas com abuso de substâncias e comportamentos sexuais de risco na vida adulta. Estes dados são relevantes, pois é sabido que há uma alta correlação entre comportamento anti-social e abuso de substâncias. Fica marcante então a necessidade, mais uma vez, de se atentar no processo de tratamento para aqueles que cometiam os maus-tratos, quase sempre os pais.

Huesmann e Eron (1984) através de um estudo longitudinal acompanharam sujeitos dos oito aos 30 anos e concluíram que crianças rejeitadas que não se identificaram com os pais e foram severamente punidas, aprenderam a usar a agressão como alternativa para se expressar. Encontraram também que quanto mais severamente as meninas eram punidas, mais abusivas com seus filhos e maridos se tornavam. Estes dados apóiam a hipótese da transmissão intergeracional da violência (Widom, 1989).

Agressividade em adolescentes e histórico infantil de abuso estão intimamente relacionados. Barnow, Lucht e Freyberger (2001) demonstraram em estudo que adolescentes agressivos diferiam de um grupo de controle de adolescentes nãoagressivos em uma elevada exposição a eventos traumáticos prévios, tais como abuso sexual, abuso físico e lares desfeitos. O comportamento parental, que inclui punição 
severa e rejeição emocional, bem como a separação prematura dos pais, também são importantes fatores na determinação do comportamento agressivo.

Um dos maiores estudiosos do comportamento anti-social, Patterson (1986, 1992), resume e afirma que as famílias de adolescentes anti-sociais são menos afetivas, têm mais conflitos e poucas habilidades sociais. Pesquisas realizadas no Oregon Social Learning Center ressaltam que pais de jovens infratores fazem pouca monitoria eficaz e usam práticas disciplinares que acabam modelando comportamentos inadequados (Patterson, DeBaryshe \& Ramsey, 1989).

Importante citar que se as práticas negativas têm efeitos definitivos sobre o desenvolvimento de condutas anti-sociais, a ausência das mesmas pela perda real ou a ausência afetiva dos pais é um dos preditores mais efetivos do comportamento infrator. Aqui define-se a disponibilidade parental (Duncan \& Mueller, 2002 apud Reppold, Pacheco e Hutz, 2005), que se refere ao apoio efetivo e emocional, à presença de comportamentos assertivos que modelam repertórios adequados, estabelecem limites e proporcionam um ambiente afetivo e seguro no qual a criança é educada para solucionar problemas.

Então, a falta de disponibilidade parental e o uso indiscriminado de estratégias de reforçamento negativo e punição na educação dos filhos, encontram-se na base do estabelecimento do padrão de comportamento anti-social. (Patterson et al, 1992).

As práticas educativas parentais que promovem comportamentos prósociais podem ser aprendidas pelos pais, rompendo a transmissão intergeracional de comportamentos anti-sociais. De acordo com Gomide (2003, 2004) o desenvolvimento de práticas educativas parentais de monitoria positiva e de comportamento moral são especialmente importantes. Em um estudo sobre comportamentos altamente desejáveis 
em crianças, Waxler e Yarrow (1979) demonstraram como a consciência de reações maternas frente aos comportamentos da criança podem ser facilitadores de atitudes prósociais. Os autores descrevem as mães cujos filhos são reparadores e altruístas como sendo aquelas que emitem reações cognitivas e afetivas congruentes com as transgressões dos filhos.

Bolsoni-Silva (2003) em um estudo sobre habilidades sociais educativas parentais encontrou que tanto o grupo de crianças com indicativos escolares de comportamentos socialmente adequados como o grupo de crianças com comportamentos socialmente indesejados recebem limites dos pais através de estratégias semelhantes, o que parece ser determinante para as diferenças comportamentais das crianças são os comportamentos de interação positivos dos pais para com os filhos.

Além das práticas educativas positivas e da afetividade dos pais como fator determinante para o desenvolvimento pró-social da criança, estudos têm focalizado a questão da resiliência, enfatizando que nem todas crianças expostas a fatores de risco tornam-se crianças anti-sociais. Fergusson, Horwood e Lynskey (1994) estudaram 942 crianças do nascimento aos 15 anos e identificaram que algumas cresceram em lares com sérios problemas, no entanto não exibiram problemas comportamentais na adolescência. Eles oferecem duas explicações possíveis para o fato: 1) a criança resiliente foi exposta a vários fatores protetivos; 2) a criança expressa outros problemas, tais como, atividade sexual precoce, uso de drogas, desordem de conduta, "passagem pela polícia", não medidos neste estudo. Eles encontraram que $50 \%$ dos que tiveram famílias disruptivas tiveram problemas na adolescência contra $13 \%$ que não tiveram. Também relataram que a prática parental violenta está diretamente relacionada com várias síndromes infantis, como distúrbios psiquiátricos e que podem levar a 
comportamento criminoso violento mais tarde. Espancamentos que resultaram em fraturas, contusões, queimaduras foram correlacionados a infratores e delinqüentes. Os meninos apanham mais que as meninas e isto pode estar relacionado com a maior violência masculina.

Podem ser três os grupos de fatores protetores para comportamentos de risco e de abuso físico: (1) características individuais, (2) processos familiares e (3) fatores extra-familiares (Perkins \& Jones, 2004).

Os pesquisadores (Perkins \& Jones, 2004) realizaram um estudo no qual esperavam encontrar que índices altos de fatores protetores reduziriam o engajamento em comportamentos de risco (ex.: consumo de álcool, uso de drogas, atividade sexual, comportamento anti-social, tentativa de suicídio e bulimia entre adolescentes abusados.

Entre os resultados encontrados por Perkins e Jones (2004), as características do grupo de pares constituíram um preditor significativo para a diminuição no engajamento em comportamentos de risco, seguidas pelo clima positivo da escola, religiosidade, suporte de outro adulto, suporte familiar, expectativa de futuro e envolvimento em atividades extra-curriculares. A maioria dos adolescentes do estudo não estavam engajados em comportamentos de risco, contudo um número significativamente maior de adolescentes abusados, quando comparados com os não abusados, estavam engajados em comportamentos de risco.

Perkins e Jones (2004) concluíram também que os fatores protetores existem em vários níveis de desenvolvimento dos adolescentes, o que parece ter fortes implicações para o trabalho com esta população. Ou seja, ampliar o número de fatores protetores disponíveis para o jovem é parte importante do tratamento que visa afastá-lo de comportamento anti-sociais. 
Portanto, a psicoterapia poderia ser incluída como um fator protetivo se for considerado seu caráter relacional que inclui situações citadas, tais como: clima positivo, suporte de outro adulto, expectativa de futuro e envolvimento em uma atividades não-escolar que proporciona autoconhecimento e bem-estar.

Ainda, explicitando a relação entre as práticas educativas negativas e o estabelecimento da conduta infratora, Gomide (2001) analisou o modelo sóciointeracionista de Patterson e elencou uma série de características comuns dos pais de crianças e adolescentes anti-sociais.

Estes pais são contingentes em suas interações com os filhos problemas, de forma que, (1) sempre falham em usar efetivamente punições para comportamentos desviantes e (2) não usam reforçamento para comportamento pró-social; (3) existe uma grande diferença entre o que os pais dizem fazer e o que de fato fazem; (4) tendem a estar irritados em suas interrelações familiares; (5) usam a disciplina inefetiva, que consiste em repreensão e apoquentação por questões triviais e ameaça de usar punição, sem concretização para fatos graves; (6) falham na monitoria ou supervisão. (7) favorecem o aprendizado da criança, onde comportamento agressivo e choro exagerado, birra são efetivos no sentido de evitar comportamentos punitivos e são, simultaneamente, capazes de produzir reforçadores; (8) permitem que estes comportamentos se fortaleçam (resistência à extinção por extinção incompleta) e que a criança literalmente coaja a família no sentido de obter permissão para permanecer nas ruas e, conseqüentemente, se engajar em grupos desviantes; (9) a disciplina relaxada é uma prática educativa altamente utilizada por estes pais e em 
decorrência do estilo abrasivo destas crianças seus pais evitam colocar limites, contingenciar os comportamentos inadequados, anti-sociais. Utilizam-se basicamente de ameaças e não cumprem as regras estabelecidas; (10) O temperamento explosivo da criança e a sua recusa em aceitar feedback negativo podem levar os pais a agirem como espectadores e não participantes da educação, passando inclusive, a rejeitar suas crianças. Esquivam-se da tarefa por terem baixa habilidade para tal; (11) usam constantemente punição física - abuso físico - de maneira inconsistente, dependendo do humor do agente punidor e não do comportamento emitido e (12) finalmente, permitem o desenvolvimento da chantagem emocional, pois as crianças choram, fazem birra, fingem sofrimento, atribuem culpa aos pais, tudo isto somente para obter concessões.(Gomide, 2001, p.47).

Na mesma linha, Hoffmann (1994 apud Gomide, 2006) aponta que pais coercitivos, cujas ações eliciam medo e raiva na criança quando ela transgride uma norma que causou dano a alguém, podem fazer com que ela deixe de focalizar as conseqüências que seu ato causou na vítima para focalizar as conseqüências que a transgressão da regra causou a si mesma. Este estilo é facilmente observável em pais de adolescentes infratores que não conseguem se colocar no lugar de suas vítimas e constantemente reclamam da medida socioeducativa recebida, considerando-a injusta, muito longa ou muito rigorosa.

Também Cavell (2000) observou que falhas por parte dos pais no estabelecimento de práticas de disciplina e monitoria levam ao comportamento antisocial, bem como a disciplina demasiadamente severa. Ele concluiu através de estudos que há correlação entre pais que exerciam monitoria fraca com os filhos e 
comportamento de risco em adolescentes: baixa freqüência de uso de preservativos ou outros contraceptivos nas relações sexuais, multiplicidade de parceiros sexuais, uso de maconha, álcool, experiência de ter sido preso e maior incidência de doenças sexualmente transmissíveis.

A ligação entre a carência afetiva e o crime, assertiva esta baseada na proposição de que a carência prejudica fortemente a capacidade para constituir relações afetivas com os outros, leva, segundo Feldman (1979), ao desenvolvimento de comportamento infrator futuro, ou seja, o jovem que viveu em ambiente com carência ou ausência de relações afetivas consistentes poderá prejudicar o outro (a vítima) sem remorsos. A vítima potencial é o indivíduo que representa o algoz do adolescente ou que, simplesmente, nada significa. Isto porque os vínculos afetivos que, sequer foram desenvolvidos com os pais, não poderão, portanto, ser generalizados para estranhos.

As práticas educativas são definidas como estratégias específicas utilizadas pelos pais ou cuidadores em diferentes contextos (Reppold, Pacheco, Bardagi \& Hutz, 2002). Uma vez que parece existir significativa relação entre a predominância da utilização de práticas negativas na educação de crianças e adolescentes anti-sociais e infratores, é possível supor que o psicoterapeuta deva trabalhar utilizando práticas educativas positivas, possibilitando aprendizagem de novos repertórios comportamentais e fornecendo ao jovem um modelo de relacionamento não-coercitivo. 


\section{Unidades de internação para adolescentes em conflito com a lei}

As intervenções e sanções relativas aos adolescentes com menos de 18 anos que cometem atos infracionais são regidas pelo Estatuto da Criança e do Adolescente (ECA, 1990). O Estatuto considera que sua prioridade é a questão da criança e do adolescente, sua proteção integral como dever da família, da sociedade e do Estado.

As medidas socioeducativas ${ }^{3}$ previstas no Estatuto da Criança e do Adolescente são: advertência (Art. 115), reparação de danos (Art. 116), prestação de serviços à comunidade (Art. 117), liberdade assistida (Art. 118), regime de semiliberdade (Art. 119) ou internação em estabelecimento educacional com privação de liberdade (Arts. 121 a 125). As instituições de internamento devem oferecer atividades pedagógicas, de escolarização e profissionalização, atividades culturais, esportivas e de lazer e assistência religiosa (caso o adolescente deseje). Também é obrigação da instituição zelar pela integridade física e mental dos internos, adotando medidas adequadas de contenção e segurança; é dever da instituição providenciar os documentos pessoais indispensáveis para que na ocasião do desinternamento o jovem tenha condições de desempenhar o papel de cidadão, reintegrando-se à sociedade (Arts.124 e $125)$.

No final de 2002 existiam cerca de 10.000 adolescentes em instituições de privação de liberdade no Brasil, dos quais $90 \%$ eram do sexo masculino, mais de $60 \%$ negros e $76 \%$ com idades entre 16 e 18 anos. As infrações cometidas por estes adolescentes eram: roubo $(29,5 \%)$, homicídio $(18,6 \%)$, furto $(14,8 \%)$ e tráfico de entorpecentes $(8,7 \%)$. Destes jovens $51 \%$ não freqüentavam mais a escola quando cometeram o delito, $49 \%$ não trabalhavam e quase $50 \%$ não chegaram a completar o

\footnotetext{
${ }^{3}$ Capítulo IV "Das Medidas Socioeducativas"
} 
ensino fundamental. $\mathrm{O}$ uso de drogas era comum a 85,6\% dos adolescentes (Ministério da Justiça, 2002).

Sposato e Pereira (2004) citam um levantamento realizado em janeiro de 2004 pela Secretaria Especial de Direitos Humanos, que mostra a existência de 19.747 jovens inseridos em medidas socioeducativas no estado de São Paulo, sendo estas medidas de internamento, internamento provisório e semi-liberdade. $\mathrm{O}$ mesmo levantamento mostrou o impressionante número de 39.578 jovens no sistema socioeducativo brasileiro; destes 18.618 encontravam-se em liberdade assistida, 9.591 em internação, 7.471 prestavam serviços à comunidade, 2.807 estavam em internação provisória e 1.091 em semi-liberdade.

Na medida de liberdade assistida o jovem é supervisionado mensalmente por um profissional do estado ou do município para que certifique-se que o mesmo está estudando, trabalhando e cumprindo os termos da sentença proferida pelo juiz. A prestação de serviços à comunidade pode ocorrer em conjunto com a liberdade assistida ou separadamente, e usualmente solicita-se ao jovem que realize trabalhos que o façam refletir sobre o comportamento inadequado que o levou a cumprir tal medida. Em caso de atividade remunerada, o salário é revertido para repara danos que possivelmente tenham sido causados pelo adolescente. Na medida de semi-liberdade os jovens residem em unidades próprias e recebem acompanhamento para estudar e trabalhar, retornando no final do dia e permanecendo no local aos finais de semana. No decorrer do processo o jovem poderá ser liberado para passar os finais de semana em casa, retornando para o semi-internato nos dias de semana. A internação provisória tem o prazo máximo de 30 dias, acontece geralmente em delegacias especializadas e antecede o recebimento da medida socioeducativa, 
No mesmo levantamento de janeiro de 2004, de acordo com a Subsecretaria de promoção dos Direitos da Criança e do Adolescente (SEDH) havia um déficit de 1.488 vagas de internação provisória, déficit de 1.499 vagas de internação e sobravam cerca de 700 vagas no sistema de semi-liberdade, principalmente no estado do Rio de Janeiro.

Segundo a Human Rights Watch, no Rio de Janeiro, em janeiro de 2004 o sistema de justiça daquele estado tinha sob custódia mais de 1700 jovens, dos quais aproximadamente 900 estavam detidos provisoriamente ou em medida de internamento, enquanto os demais cumpriam liberdade assistida ou prestavam serviços comunitários (HRW, 2004).

De acordo com as Diretrizes de Riad (1990), os Princípios Orientadores das Nações Unidas para a Prevenção da Delinqüência Juvenil têm como um de seus princípios fundamentais a prevenção. Hutz (2002) ressalta que a agressão e a violência apresentadas pelos jovens infratores podem ser entendidas como um sinal de má adaptação perante circunstâncias e desafios de vida. Então, a prevenção deveria se dar tão logo se manifestassem as primeiras dificuldades de adaptação da criança.

Segundo dados fornecidos pelo IASP-PR (Instituto de Ação Social do Paraná), em agosto de 2006, ${ }^{4} 416$ adolescentes encontrava-se cumprindo medida socioeducativa no estado, dentre os quais 129 por homicidio (31\%).

Quando o ECA estabelece as medidas socioeducativas, tem como objetivo reeducar e reintegrar o jovem à família e à sociedade. Contudo, Macagnan da Silva (1999), descreve em sua dissertação de mestrado um índice de 61,8\% na reincidência na internação privativa de liberdade (que é uma das possíveis medidas), indicando a pequena eficácia dos tratamentos ofertados pelas instituições

\footnotetext{
${ }^{4}$ Levantamento obtido no mês de agosto de 2006.
} 
governamentais responsáveis, apesar de não fornecer dados acerca da metodologia para o cálculo deste índice.

As unidades de internamento frequentemente têm problemas em gerenciar comportamentos violentos e disruptivos dos adolescentes. O relatório da OAB construído com base na vistoria realizada em 2006 nas unidades de internamento por todo o país mostra que não apenas inexistem programas na maior parte delas, como em alguns locais os profissionais temem os adolescentes (OAB e Conselho Federal de Psicologia, 2006).

No ano de 2006 (no dia 15 de março) uma inspeção organizada conjuntamente pela Ordem dos Advogados do Brasil e Conselho Federal de Psicologia, foi realizada concomitantemente em 30 unidades de internamento em 21 estados brasileiros e no Distrito Federal. O relatório (OAB e Conselho Federal de Psicologia, 2006), fruto das visitas que aconteceram simultaneamente, denuncia um panorama precário na maioria das unidades. A comissão recebeu queixas de espancamentos em $56,66 \%$ das unidades e puderam observar as lesões provocadas nos adolescentes. Em $17 \%$ não havia nenhum tipo de escolarização, $50 \%$ não possuíam atividades de profissionalização e $80 \%$ possuíam estrutura física inadequada. Quanto à assistência jurídica, 56,66\% não a oferecia aos internos e em 18 das 30 unidades houve denúncias acerca das condições de higiene e precariedade ou inexistência do atendimento à saúde. Porém, ainda mais alarmante foi que em nenhuma unidade visitada, foram disponibilizados qualquer tipo de Programa Socioeducativo para atingir os objetivos definidos pelo ECA - o de reeducar e reintegrar o jovem à família e à sociedade Portanto, frente a este quadro percebe-se o despreparo, descaso e ineficácia das políticas estaduais para efetivamente cumprirem o que determina a lei. 
Um trabalho realizado em um centro de socioeducação no Paraná (Menezes, 2006) utilizou a observação direta da rotina das atividades e apontou que a atuação de educadores sociais, principais responsáveis pela execução das medidas socioeducativas, não corresponde aos preceitos do ECA, sendo que os mesmos atuam majoritariamente de forma coercitiva, servindo como agentes punitivos ao invés de educadores.

São escassas, inclusive, as unidades que possuem tratamentos especializados para comportamentos violentos e hostis, na maior parte delas os métodos para se lidar com a agressividade limita-se ao procedimento de isolamento e restrições de atividades.

Gomide (1998) também demonstrou que a realidade das unidades de internamento não está próxima das premissas do ECA. Em uma instituição na qual implementou um programa que encaminhava adolescentes para trabalhar em uma estatal conveniada, dos 12 adolescentes selecionados apenas seis iniciaram o processo de integração. Uma hipótese para explicar o resultado pouco promissor foi que o despreparo e a falta de habilidades e conhecimento que poderia ter sido adquirido pelos adolescentes durante o internamento tivesse sido uma das causas do não engajamento. Gomide (1998) relatou ainda que as escolhas dos adolescentes pelas oficinas de profissionalização se davam na grande maioria pelo instrutor que fosse mais permissivo e tratasse os adolescentes como "camaradas" (p.67).

Em um estudo preliminar sobre o nível do desempenho acadêmico, Gomide, Rocha e Watanabe (2005) levantaram que entre 17 adolescentes infratores, com tempo médio da atual internação de 14 meses e todos reincidentes, nenhum se encontrava no nível de escolarização esperado, tendo déficit escolar de sete anos em média, apesar das atividades escolares existentes na instituição, sugerindo o não 
cumprimento do objetivo da medida socioeducativa como proposta pelo Estatuto. E sobre a questão do desenvolvimento pessoal afetivo que deveria ser promovido dentro das instituições correcionais através da figura do educador, Assis (1999) afirmou que a ausência de afeto e confiança com o mundo exterior se mantém dentro das instituições, dificultando a aprendizagem de novos padrões de relacionamento necessários à reinserção social.

Poucos estudos (ex.: OAB e Conselho Federal de Psicologia, 2006; Gomide, Rocha e Watanabe, 2005; Menezes, 2006) mostram que na realidade brasileira as intervenções com adolescentes infratores que sofreram abuso na infância são ineficazes na promoção do desenvolvimento social e emocional destes jovens (Hutz, 2002). Este autor levanta dois principais fatores como impeditivos da modificação do comportamento infrator nas instituições de internamento: a conduta inadequada dos trabalhadores das unidades e o treino na delinqüência que acontece entre o grupo de iguais. Os trabalhadores deveriam apresentar modelos adequados de comportamento, inclusive daqueles alternativos à violência, bem como deveriam reforçar, além de facilitar o aparecimento, de comportamentos adequados e de ligação afetiva com os adolescentes. Porém, os grandes grupos de adolescentes acabam servindo para reforçar e ensinar comportamentos agressivos que deveriam ser eliminados.

\section{Tratamento de comportamento anti-social e infrator}

Gerald R. Patterson e John B. Reid são pioneiros ao delinear tratamentos e programas preventivos para comportamentos de risco e anti-sociais. Juntos fundaram o OSLC (Oregon Social Learning Center) em 1977 com alguns colegas que já trabalhavam nesta linha na Universidade do Oregon e mais tarde no Instituto de Pesquisa do Oregon. Este é hoje um pólo mundial na produção de pesquisa e dados científicos sobre diagnóstico, intervenção e prevenção de problemas comportamentais 
de crianças, adolescentes e famílias em situação de risco (ver www.oslc.org). As publicações de seus profissionais estão presentes em grande parte da literatura de referência nesta área (Stoff, Breiling \& Maser, 1997; Patterson et. al 1992; Reid, Patterson \& Snyder, 2002). Inicialmente o trabalho do OSLC enfocava o desenvolvimento e a avaliação de programas educativos de treino parental baseados em pesquisa e programas de treinamento para o contexto clínico. Na década de 80 este trabalho continuou e outro foco foi adicionado: estudar o desenvolvimento da criança e da família ao longo do tempo. Foi em 1990 que o OSLC recebeu o título de Centro de Pesquisa Preventiva fundado pelo Instituto de Saúde Mental. O norte do Centro de Pesquisa Preventiva do Oregon é a prevenção de problemas de comportamentos antisociais e a delinqüência durante a infância, os chamados distúrbios de comportamento. O Centro também promove programas de atendimento clínico. O OSLC, desde o início da década de 80 tem desenvolvido e pesquisado o que se chama de Multidimensional Treatment Foster Care Program ${ }^{5}$, um tratamento custeado pelo estado para adolescentes com problemas de conduta, bem como tem realizado várias experiências de treino de habilidades parentais tais como o "Linking the Interests of Families and Teachers" (LIFT) e o "Marriage and Parenting in Stepfamilies"” (MAPS).

De acordo com relatório do SINASE (Sistema Nacional de Atendimento Socioeducativo, 2006) em 2002 havia quase dez mil adolescentes cumprindo medida socioeducativa de internação e internação provisória. Destes, levantou-se que:

- $90 \%$ eram do sexo masculino,

- $76 \%$ tinham entre 16 e 18 anos,

- $63 \%$ eram pardos ou afrodescendentes,

\footnotetext{
${ }^{5}$ Programa de Tratamento com pais adotivos

${ }^{6}$ Conectando os Interesses de Famílias e Professores

${ }^{7}$ Casamento e Parentalidade em Famílias Substitutas
} 
- $51 \%$ não freqüentavam a escola,

- 90\% não concluíram o Ensino Fundamental,

- $49 \%$ não trabalhavam,

- $85,6 \%$ eram usuários de drogas,

- $81 \%$ viviam com a família quando praticaram o ato infracional que levou ao internamento,

- $12,7 \%$ viviam em famílias que não possuíam renda mensal,

- $66 \%$ viviam em famílias com renda mensal de até dois salários mínimos.

É importante frisar que estes dados se aplicam a adolescentes com idades entre 12 e 21 anos. O ECA (1990) estabelece em seu segundo artigo, que são considerados adolescentes as pessoas entre 12 e 18 anos, porém em parágrafo único complementa que nos casos expressos em lei, o estatuto se aplica excepcionalmente às pessoas entre 18 e 21 anos de idade. Isto ocorre porque alguns jovens que cometem atos infracionais são apreendidos pouco antes de completarem dezoito anos. Quando isto ocorre, ele responde à medida prevista de acordo com o estatuto, podendo permanecer sob esta lei específica até no máximo os 21 anos.

Os pais são importantes modelos para seus filhos e as práticas parentais, que são os comportamentos dos pais em relação aos filhos, influenciam os padrões comportamentais observados nas crianças. É importante desenvolver estratégias de trabalho e intervenções com os pais para que estes possam desenvolver atitudes adequadas com seus filhos, já que as práticas educativas exercem influências sobre a formação e desenvolvimento da criança. 
Porém muitos dos jovens descritos acima não contam com a rede de apoio familiar, de forma que seus pais, ou qualquer outro parente próximo, dificilmente ou pouco provavelmente participariam de programas preventivos e nem participariam do tratamento para aprendizagem de outros padrões comportamentais que não o antisocial; como então deveria ser constituído um processo de recuperação para adolescentes infratores, sem a participação e suporte familiar, tendo como base princípios da análise do comportamento?

A análise do comportamento parece ser uma abordagem apropriada para programas de intervenção com adolescentes infratores, pois trabalhos que efetivamente modificam arranjos de contingências sociais são descritos na literatura (Teixeira, 2002; Chequer \& Martinelli, 2004a; Chequer \& Martinelli, 2004, b; Cirino, 2005; Goyos \& Rossit, 2005), possibilitando sua réplica e utilização em outros ambientes. Contudo pouquíssimos destes trabalhos referem-se à população de adolescentes infratores de alto-risco. Logo, parece que quando se utiliza uma abordagem calcada em princípios científicos, os benefícios de uma intervenção podem ser mais facilmente divulgados e compreendidos por um maior número de pessoas, aumentando sua aplicabilidade.

Hutz (2002) sugeriu intervenções, tanto de prevenção quanto de tratamento, para crianças e jovens autores de atos infracionais, baseadas sempre na importância do contexto. “(...) contexto deve ser compreendido em termos de oportunidades e experiências que ele oferece para que determinado comportamento problemático se repita e, conseqüentemente, se mantenha e fortaleça ou para que ele se elimine e seja substituído por outro mais adaptativo. Contexto, então pode ser a casa, a escola, a casa dos parentes, vizinhos e amigos, os locais de lazer e de trabalho, as instituições que executam medidas de proteção ou socioeducativas e o setting terapêutico" (pp.170-171). 
É fundamental que se diga que a literatura científica na área aponta para as interações entre pais e filhos como principal meio de estabelecimento e manutenção dos comportamentos infantis (Patterson et. al 1992), o que explica o amplo uso de treinamentos parentais tanto em âmbito preventivo quanto em tratamento de comportamentos anti-sociais.

Nesta área inúmeros trabalhos têm sido elaborados, sobre o que se chama orientação para pais e treino parental, sobretudo visando pais de crianças e adolescentes internados ou sob um tipo de medida restritiva e famílias em situação de risco (Berri, 2004; Chamberlain, Fisher \& Moore, 2002; Dishion \& Kavanagh, 2002; Patterson, 2002; Snyder \& Stoolmiller, 2002; Thornberry \& Krohn, 1997; Cairns, Cadwallader, Estell, \& Neckerman, 1997; Reid \& Eddy, 1997; Reid \& Eddy, 2002; Reid \& Eddy, 2002b; Offord, 1997; Hawkins, Arthur \& Olson, 1997; Southam-Gerow \& Kendall, 1997; e Tolan \& Gorman-Smith, 1997).

A literatura também descreve programas comunitários, treino para pais, psicoterapia individual, de grupo e familiar e programas de manejo da raiva, todos como intervenções psicológicas (Tolan \& Gorman-Smith, 1997; Rosenblat \& Rosenblat, 1998; Thompson, 1998; Wood, 1998; Vien \& Beech, 2006). Feldman (1993) diz que dois grandes marcos podem ser observados na literatura sobre o tratamento de infratores: um acentuado declínio nas abordagens amplamente psicodinâmicas e um aumento concomitante na ênfase comportamental; e paralelamente a isto um aumento na qualidade metodológica das pesquisas divulgadas - "embora ainda haja um longo caminho até que o nível ideal da literatura sobre tratamentos clínicos seja atingido" (p.380). Afirma ainda que a esmagadora maioria de programas de tratamento refere-se a infratores adolescentes ou pré-infratores, ou seja, muitos dos programas descritos são preventivos. 
Florsheim, Behling, South, Fowles e DeWitt (2004) em um estudo que partia da dúvida quanto à eficácia dos tratamentos oferecidos nos centros de recuperação para adolescentes infratores nos Estados Unidos, apresentam dados relevantes para a discussão quanto ao tipo de programa e avaliação das atividades realizadas nas instituições correcionais. Os autores dizem que muito se sabe através de pesquisas sobre o desenvolvimento de criminosos juvenis perigosos, mas que pouco se sabe cientificamente sobre quais os componentes do atual sistema de tratamento e recuperação destes jovens são mais efetivos. O curso do tratamento de cada jovem, o que significa dizer que muitos desses jovens passam por vários programas de recuperação, deve-se a vários fatores incluindo o contexto familiar, as necessidades de cada etapa do desenvolvimento humano, os resultados em programas anteriores e o quanto ele, o jovem, pode ser uma ameaça para a comunidade. A Divisão de Prevenção da Delinqüência e Justiça Juvenil (Office of Juvenile Justice and Delinquency Prevention) chama de "estratégia compreensiva" a mudança de jovens de um programa para outro dependendo das necessidades de cada momento. Esta estratégia baseia-se no princípio de sanções gradativas, através do qual as atividades oferecidas aos jovens dependem dos níveis individuais de funcionamento e grau de ameaça à sociedade e podem ser: tratamento, supervisão, desenvolvimento de habilidades e oportunidades para reparação de danos. Na medida em que adolescente vai se recuperando o nível de envolvimento do sistema diminui. Este tipo de estratégia configura um desafio para a avaliação do programa de recuperação como um todo, pois não é possível separar os efeitos de um programa dos de outro e os efeitos dos programas provavelmente são cumulativos ao longo do tempo.

Cowles e Washburn (2005) apontam que as abordagens nas quais se baseiam os programas de tratamento das instituições para adolescentes infratores variam 
muito e podem incluir intervenções cognitivo-comportamentais, atividades recreativas terapêuticas, treino de desenvolvimento moral, treino de habilidades específicas e psicoterapia tradicional. Os autores apontam ainda que várias entidades americanas têm contratado assessoramento para reestruturar suas unidades de manejo intensivo e disciplinar. Esta assessoria psicológica e comportamental visa implementar procedimentos para a modificação do padrão comportamental ao invés de isolar ou apenas punir o adolescente.

Um exemplo importante citado por Cowles e Wasburn (2005) são as duas Unidades de Manejo Intensivo ligadas a Washington State JRA (Administração de Reabilitação Juvenil do Estado de Washington), nas quais encontram-se os adolescentes infratores com crimes mais graves do estado de Washington. Os internos do sistema de recuperação que se engajam em comportamentos disruptivos, violentos ou de não cumprimento substancial das regras são enviados às Unidades de Manejo Intensivo, nas quais uma das atividades das quais participam é a psicoterapia. Os autores não apresentam dados quanto aos resultados dos programas, mas descrevem: 45\% dos adolescentes do JRA foram condenados devido a crimes violentos, $18 \%$ por crimes sexuais e $5 \%$ a crimes relacionados a entorpecentes. A média de idade é de 16 anos e a grande maioria é do sexo masculino (92,3\%). Quando ingressam no programa os adolescentes são avaliados quanto ao nível de periculosidade para que possam ser direcionados à programação e nível de segurança adequados. Aproximadamente $30 \%$ deles têm sido classificados como de "risco de segurança mínimo", enquanto que 58\% são considerados de risco médio e $12 \%$ de "risco de segurança máximo". Do total de adolescentes considerados de alto risco 55\% apresentam algum tipo de abuso de drogas e $21 \%$ apresentam alguma deficiência cognitiva (ex.: retardo mental leve). A média de tempo de internamento nestas unidades é de 320 dias (Cowles \& Washburn, 2005). 
As intervenções, sobretudo as preventivas, sejam elas grupos de treinamento ou psicoterapia familiar (ex. Tratamento Multi-sistêmico de Henggeler et al., 1992) devem instrumentalizar os adultos e familiares envolvidos no processo ao invés de simplesmente culpá-los pela manutenção do comportamento anti-social do jovem ou da criança. Trazer estes adultos para o processo é de fundamental importância e se constitui em difícil tarefa terapêutica, pois padrões de interação coercitivos do qual eles fazem parte devem ser modificados, requerendo que seus comportamentos sejam modificados.

O sucesso da intervenção depende em grande parte do envolvimento e do compromisso assumido pelos adultos que formarão a rede de apoio ao adolescente antisocial (Reid \& Eddy, 2002). Feldman (1993) descreve diversos estudos (Gottschalk, Davidson, Gensheimer \& Mayer, 1987; Garret, 1985) que realizaram levantamento bibliográfico sobre tipos e resultados dos tratamentos para infratores. Ele destaca que a maioria dos estudos trata de programas para adolescentes, muitos deles, e inclusive os mais eficazes, com a presença da psicoterapia comportamental (ou modificação do comportamento) individual. Ele reconhece a importância do envolvimento dos pais no tratamento, mas ressalta que raramente estes estão disponíveis para tratamento, ao contrário dos programas preventivos.

No Brasil, a existência de redes de apoio, sejam elas familiares ou sociais/ governamentais são precárias. Este fato fez com que neste estudo fosse dada prioridade às alternativas que não envolvem, principalmente, a participação da família. Consequentemente, se torna de grande relevância dar atenção às intervenções utilizadas durante os internamentos, nas quais não se prescinde da presença de familiares.

Em estudos sobre os resultados de intervenções em ambientes onde há restrição de liberdade, a abordagem cognitivo-comportamental apresenta os melhores 
resultados na redução da reincidência (Alen, MacKenzie \& Hickman, 2001; Andrews et al., 1990). Andrews et al. (1990) ressalta que além da abordagem teórica adequada, deve ser cuidadosamente considerada a estrutura de intervenção em grupo, pois o diálogo aberto em grupos formados por infratores graves é um fator criminogênico.

Estas informações levaram à busca de estudos que descrevessem a utilização de estratégias individualizadas de tratamento para adolescentes anti-sociais. Um dos estudos encontrados (Timmerman \& Emmelkamp, 2005), apesar de não se referir a adolescentes, relata uma experiência bem sucedida de tratamento individualizado com infratores graves em uma prisão especial na Holanda. A importância de tratamentos individuais, segundo Feldman (1993), reside na evidência empírica de que a psicoterapia de grupo pode aumentar os níveis de reincidência criminal (ex. Adams \& Vetter, 1981), pois seria uma situação onde se promovem relações entre os pares além de ser uma forma na qual a interação com o profissional segue com o estigma carregado há anos pelas histórias das instituições correcionais.

\section{PSICOTERAPIA ANALÍTICO-COMPORTAMENTAL COM ADOLESCENTES INFRATORES}

A psicoterapia é uma atividade realizada por um profissional especialmente habilitado que faz uso da relação interpessoal para ajudar as pessoas a desenvolver uma compreensão sobre elas mesmas, possibilitando que façam modificações em suas vidas. Deve consistir em uma relação claramente contratada e que segue princípios a fim de permitir às pessoas obterem ajuda para analisar e solucionar questões interpessoais e intrapessoais (Castonguay \& Beutler, 2006; Grant, 1997).

Teoricamente, são inegáveis os benefícios que a psicoterapia pode oferecer aos indivíduos que não se adaptam às normas sociais e vivem à margem dos grupos. Autores como Feldman (1993), Reid, Patterson e Snyder (2002) destacam a 
abordagem comportamental como a psicoterapia mais adequada para infratores encarcerados. Hutz (2002) concorda que o adolescente com histórico infracional deve aprender novos repertórios comportamentais sobre ele mesmo e sobre o mundo, desenvolvendo novas maneiras de se relacionar e beneficiando-se das situações de aprendizagem ofertadas pelo ambiente, e não apenas aprender através de métodos coercitivos aquilo que não deve fazer. "Uma forma de fornecer esta base é a implementação de psicoterapias cognitivo-comportamentais dentro das instituições, durante o período no qual o jovem cumpre sua medida socioeducativa" (p.178).

A psicoterapia analítico-comportamental, adotada no presente trabalho, difere da psicoterapia cognitivo-comportamental, embora ambas sejam comportamentais. As especificidades da psicoterapia analítico-comportamental podem ser descritas em termos de quatro níveis de análise: o tecnológico, o metodológico, o conceitual e o filosófico. O nível tecnológico caracteriza-se pela utilização de procedimentos derivados da pesquisa experimental; o metodológico, pela análise de contingências; o conceitual, pela adoção dos princípios do comportamento; e o filosófico, pela rejeição ao mentalismo (Meyer, 1995).

O objetivo geral da psicoterapia analítico-comportamental é o de criar novas condições de aprendizagem de estratégias de ação, avaliação e modificação, buscando alterar o comportamento desajustado. Compreende a identificação e a análise das funções que os comportamentos ditos problemáticos têm, a fim de que sejam estabelecidos objetivos de aprendizagem de novos comportamentos que possam ser implementadas e treinadas (Sénéchal-Machado, 2002).

O terapeuta analítico-comportamental deve se apresentar como audiência não-punitiva a fim de minimizar o sofrimento do cliente. Ele deve ser um agente reforçador, que proporciona situações nas quais o cliente pode aumentar sua tolerância a 
emoções aversivas (Cordova \& Kohlenberg, 1994). Isso está de acordo com Skinner (1974/1953) que definiu a terapia como uma situação cuja função maior seria reduzir os efeitos gerados pela punição. Dentre estes efeitos estariam reações emocionais de revolta, resistência, medo, ansiedade, raiva e depressão, decorrentes das principais agências controladoras: escola, governo, religião e família.

A interação com o terapeuta constitui-se em uma oportunidade para que o cliente reproduza o padrão que tem lhe trazido problemas. Desta forma o terapeuta proporciona interações que ajudem o cliente a aprender formas mais efetivas de responder (Cahill, Carrigan, \& Evans, 1998; Follette, Naugle \& Callaghan, 1996; Kohlenberg \& Tsai, 2001; Rosenfarb, 1992). O terapeuta deve apresentar diante das formas problemáticas de interação, conseqüências diferentes daquelas apresentadas no ambiente natural do cliente já que estas têm mantido seus comportamentos-problema (Follette et. al 1996; Rosenfarb, 1992).

Skinner (1974/ 1953) disse que a psicoterapia era uma agência controladora diferenciada, pois além de não utilizar controle aversivo deveria lidar com os efeitos deste tipo de controle sobre o indivíduo.

Pesquisas apontam que um dos preditores mais fortes dos resultados do tratamento é a qualidade da aliança terapêutica entre o cliente e o terapeuta (Follette, Naugle \& Callaghan, 1996; Kohlenberg \& Tsai, 2001; Rosenfarb, 1992). Aliança terapêutica é definida como a relação colaborativa que se desenvolve entre o cliente e o terapeuta facilitando a ocorrência de mudanças comportamentais. Depende de alguns aspectos, dentre eles: o nível de concordância quanto aos objetivos terapêuticos, a habilidade de se engajar colaborativamente em tarefas mutuamente negociadas com o objetivo de alcançar esses resultados e o estabelecimento de uma relação de confiança e 
respeito mútuo que proporcione ao cliente um contexto seguro para explorar suas dificuldades interpessoais.

Com infratores ocorre da mesma forma. Marshall e Serran (2004) realizaram um estudo de levantamento bibliográfico acerca da importância dos comportamentos do terapeuta nas estratégias de psicoterapia com criminosos, especialmente com abusadores e concluíram que a relação terapêutica pode ser utilizada pelo terapeuta, também com os criminosos, para construir aproximação e confiança. Ressaltou a importância destas habilidades do terapeuta serem especialmente desenvolvidas durante a formação profissional.

Em uma pesquisa com homens encarcerados (Florsheim, Shotorbani, Guest-Warnick, Barrat e Hwang, 2000) os resultados mostram que uma aliança terapêutica positiva, avaliada três meses depois do inicio do procedimento, está relacionada a mudanças psicológicas positivas e predisseram taxas mais baixas de reincidência.

Entretanto, outras pesquisas encontraram resultados que indicam necessidade de cautela ao se afirmar que a aliança terpêutica é um forte preditor de resultados com determinadas populações. De acordo com as afirmações de Castonguay e Beutler (2006), clientes com um alto nível de comprometimento provavelmente se beneficiarão menos da terapia do que aqueles com um melhor nível de funcionamento no pré-tratamento, e clientes que enfrentam dificuldades financeiras ou ocupacionais podem beneficiar-se menos do tratamento e ainda, clientes que viveram problemas interpessoais significativos durante o desenvolvimento inicial podem ter dificuldade para responder à psicoterapia. Para estes autores, os resultados obtidos com adolescentes infratores não têm sido muito promissores, pois estes são clientes que atendem a vários critérios que dificultam o processo terapêutico. 
Na mesma linha, há evidências de que dependendo do grupo específico do adolescente a natureza da relação entre a aliança terapêutica e o resultado do tratamento pode variar, sendo que o desenvolvimento da aliança terapêutica em um grupo de adolescentes internados foi mais preditiva do progresso do tratamento do que em um grupo de adolescentes que sofreram abuso (Horvath \& Luborsky, 1993).

Garotos com desordens comportamentais, com história de abuso de substâncias e que estão engajados com grupos de pares desviantes ou que possuem extenso registro de comportamento infrator estão sob maior risco de fracassar nos processos de recuperação e reinserção social, portanto parece coerente admitir que também estão sob maior risco de fracassar na psicoterapia. $O$ infrator não possui habilidades de relacionamento interpessoal e de resolução de problemas fora do grupo desviante (Feldman, 1993), estes fatores podem de fato dificultar a formação de uma aliança terapêutica necessária ao sucesso da psicoterapia e devem ser objeto de atenção extra dos profissionais que trabalham com estas populações.

$\mathrm{Na}$ mesma direção, apontando as dificuldades da psicoterapia com infratores, Florsheim et al (2000) afirmaram que quase metade de todos os infratores colocados em programas sociais não completa o tratamento e aqueles que completam geralmente fracassam ao demonstrar mudanças psicológicas ou comportamentais clinicamente significantes. Para os autores, uma das maiores dificuldades encontradas é a resistência ao tratamento por parte dos adolescentes mais agressivos e anti-sociais. Esta resistência pode ser compreendida em termos dos efeitos do controle aversivo exercido através da punição pelas agências controladoras, como foi descrito por Skinner (1974/ 1953). De acordo com este autor o indivíduo que fica demasiado exposto ao controle aversivo das agências governamentais, por exemplo, pode responder a este 
controle através da resistência passiva que "consiste em simplesmente não se comportar de conformidade com os procedimentos controladores"(Skinner, 1974/ 1953, p. 392).

Um dos indicadores de que a psicoterapia teve efeitos satisfatórios é a diminuição ou a não-reincidência criminal. Reduzir reincidência é tarefa complexa e segundo McNeill, Batchelor, Burnet e Knox (2005) diz respeito essencialmente à aquisição de mudanças positivas na vida dos infratores. $O$ ponto de partida para a mudança é demonstrado através de resultados de pesquisas recentes sobre as necessidades, realizações e características demográficas do infrator sob supervisão especializada. Sendo que os infratores têm altos níveis de necessidades, isto significa que além de trabalhar com o cliente-infrator e seu comportamento socialmente inadequado, os profissionais freqüentemente têm que lidar com problemas relacionados a práticas parentais deficitárias, de abuso, de negligência, relações danificadas, pares anti-sociais e criminosos, baixo nível de escolaridade, pobreza, situação de moradia precária ou falta de moradia.

A tarefa do psicoterapeuta ao tratar do adolescente infrator tem características que diferem do trabalho com outros clientes em consultório. $\mathrm{O}$ envolvimento do psicoterapeuta não ficará restrito ao consultório e nem ao adolescente ou criança, o que deixa evidente a primeira característica necessária para trabalhar com o comportamento anti-social do adolescente infrator: a disponibilidade do psicoterapeuta. Quando se tratam de clientes considerados "desafios clínicos", Beck (2007) aponta que o psicoterapeuta geralmente se sente sobrecarregado porque tenta se responsabilizar e (ou) então não consegue estabelecer limites apropriados. Ou seja, esta clientela demanda comportamentos diferenciados se comparada às demais. É importantíssima a capacidade do psicoterapeuta de modular o grau de empatia, por exemplo, de acordo com o cliente, de forma que a empatia seja uma facilitadora para o 
fortalecimento da aliança terapêutica e não um obstáculo à mesma se for confundida pelo indivíduo com pouco repertório pró-social como permissividade ou fraqueza.

No ambiente restrito de atendimento a adolescentes infratores cumprindo medida socioeducativa de internamento, o psicoterapeuta rapidamente pode se tornar figura de referência no dia a dia do adolescente. Vários fatores parecem contribuir para isso. Primeiro, a aversividade do ambiente de internação representada pela instituição que tem a função de manter a ordem e o seguimento de regras leva o jovem a perceber o ambiente da psicoterapia como um momento privilegiado no qual ele pode se expressar de maneira franca e aberta sem a presença de outras pessoas da instituição.

Segundo, em unidades nas quais os alojamentos limitam a interação entre os adolescentes (seja por comportarem um número reduzido de jovens ou até por serem individuais) a oportunidade de deixar o alojamento já é algo que pode ser reforçador. Portanto, como a psicoterapia acontece em locais reservados, afastados dos alojamentos, este já pode ser um fator que faz com que o adolescente "deseje” fazer psicoterapia. Feldman (1993) afirma: “É questionável se muitos dos infratores privados de liberdade compartilham dos objetivos com o psicoterapeuta, ou ao invés disso têm um outro tipo de desejo (por exemplo, no contexto da prisão) por um ambiente tranqüilo e bem organizado no qual ninguém causa problemas para ninguém” (p. 402).

Terceiro, o uso de técnicas e atividades que estejam de acordo com as preferências do adolescente facilita a percepção de que o profissional constitui-se em uma audiência não-punitiva e os efeitos disso são claros: sem o receio de ser punido o adolescente apresenta seus comportamentos inadequados e possibilita ao psicoterapeuta trabalhá-los no momento em que ocorrem, de forma que o jovem sente-se aceito e percebe que de fato tem mais um indicativo de que pode confiar no psicoterapeuta. $\mathrm{O}$ 
vínculo é fundamental para que o objetivo global da psicoterapia como diminuição da reincidência criminal seja atingido.

Portanto, o psicoterapeuta adquire uma função importante na educação do adolescente infrator e por isso pode ser considerado um cuidador. Um estudo sobre uma unidade americana de manejo intensivo (Inderbitzin, 2007) que abriga apenas infratores graves mostra que os profissionais que lá trabalham possuem características peculiares quanto ao valor que o trabalho com aquela população possui para a sociedade, sendo estes valores o que os mantém neste trabalho tão desafiador. A autora descreve que a natureza do trabalho requer que os profissionais desempenhem vários papéis simultâneos: conselheiro, educador social ${ }^{8}$, treinador e pai substituto. Alguns destes profissionais são psicoterapeutas por formação universitária.

É relevante citar que a maioria dos estudos sobre tratamentos utiliza abordagens multidimensionais (incluem além de psicoterapia, treino em resolução de problemas, manejo da raiva, orientação vocacional, entre outros) (Florsheim et al., 2000). Poucos estudos, porém centralizam-se em fatores específicos que possam predizer resultados positivos no tratamento a infratores resistentes, não deixando claro que variáveis estão mais significativamente relacionadas à mudança (Florsheim et al., 2000). Assim, é importante que pesquisadores clínicos dirijam sua atenção para identificar fatores do tratamento que aumentem a probabilidade de resultados positivos entre adolescentes anti-sociais também em ambientes de intervenção comunitária onde acontece grande parte dos tratamentos.

No trabalho psicoterápico com adolescentes infratores é possível observar padrões de comportamento descritos claramente pela literatura e que diferem dos padrões comportamentais da população não anti-social. Os comportamentos mais

\footnotetext{
${ }^{8}$ A palavra original é "corrections officer”, que no Brasil seria equivalente ao educador social.
} 
emblemáticos desta população são: a hostilidade, a mentira, atribuição de culpa ao outro, a falta de vergonha, falta de autocrítica e a falta de expressão adequada de sentimentos e a dificuldade de estabelecer vínculos.

Com base nesta literatura podem ser construídos dois grupos de comportamentos para futuras análises: um de comportamentos indesejáveis, ou antisociais, que são o alvo da modificação de comportamento, e outro de comportamentos desejáveis ou pró-sociais que são as metas da psicoterapia em termos de aquisição comportamental. No grupo de comportamentos indesejáveis ou inadequados estão a hostilidade, a mentira e atribuição de culpa dos próprios atos aos outros.

A hostilidade é a característica mais marcante e evidente do comportamento anti-social. Pode ser verbal vocal ou gestual, e pode em algumas situações ser acompanhada pela agressão física. No dicionário o verbo hostilizar definese como: tratar com agressividade ou inimizade; trocar agressão; opor-se a ou opor-se mutuamente, revelar hostilidade para com alguém ou algo; acolher mal; fazer guerra a; provocar dano; guerrear, prejudicar (Houaiss, 2001). Segundo autores que estudam relações interpessoais (ex.: Del Prette e Del Prette, 2001; Caballo, 1993) indivíduos considerados hostis têm relacionamentos superficiais, menos satisfação profissional e altos níveis de estresse. O padrão de comportamento hostil é uma constante nas descrições de estudiosos do comportamento anti-social e portanto precisa ser compreendido sob a ótica da função que adquiriu na vida do indivíduo e quais reforços são seus mantenedores, para que então possa ser trabalhado.

O segundo comportamento indesejável sobre o qual é preciso discorrer é o de mentir. Para que se entenda o comportamento de mentir é preciso falar da vergonha, pois quem mente, como os infratores de alto-risco, não sente vergonha. A vergonha é um sentimento humano básico, atualmente abordado com um sentimento 
moral (Araújo, 1999). Possui papel regulador nas relações interpessoais e intrapessoais e segundo Araújo (1999) pode ser considerada como um dos sentimentos mais relevantes para nossa experiência com o mundo. A vergonha pode se refletir sobre o corpo do sujeito, dependendo da situação em que surge, se na interrupção de uma relação interpessoal ou se em uma exposição pública. Nos infratores raramente estas reações corporais de vergonha são observadas.

Araújo (1999) cita Darwin como sendo o pioneiro no estudo científico da vergonha no comportamento humano. Segundo Darwin (1872 apud Araújo, 1999) a vergonha é uma característica da espécie humana, representada pelo rubor da face; ele acreditava ser este sentimento o mais peculiar e mais humano de todas as expressões e que seu surgimento depende de dois elementos: a reflexão sobre si mesmo de alguma característica de aparência pessoal e o pensamento sobre o que os outros pensam de nós. Se então os infratores não parecem expressar este sentimento, é possível supor que não procedem a estas avaliações sobre eles mesmos ou de como parecem aos olhos de outras pessoas, o que impele a refletir sobre como chegaram a este padrão de comportamento.

A vergonha geralmente é vista como um sentimento atrelado à culpa, mas alguns autores declaram que embora muitas vezes possam se manifestar juntos são sentimentos de natureza distinta e não podem ser confundidos. Hultberg (1988 apud Araújo, 1999) afirma que esses sentimentos não podem ser vistos como opostos, uma vez que são constantemente experienciados juntos, mas a culpa pode ser vista como uma reação a uma ação, enquanto a vergonha como reação a um modelo existencial.

Boonin (1983, apud Araújo, 1999) define que a culpa tem um papel fundamental na tarefa de regulação das condutas humanas pelas regras, enquanto que a vergonha desempenha um papel correspondente em regular a existência humana em 
termos de valores e ideais. A culpa é fundamentalmente relacionada a transgressões e violações, a vergonha relaciona-se a fracassos, imperfeições, inadequações e fraquezas.

Partindo destas definições e conhecendo o que a literatura aponta como sendo os padrões de comportamento do infrator, bem como o padrão de comportamento das famílias anti-sociais, é possível sustentar que se a culpa relaciona-se à transgressão e estes jovens não tem suas condutas guiadas por regras e normas, pois não aprenderam este comportamento em suas famílias ou núcleos cuidadores, é compreensível que não sintam culpa. Também se pode imaginar, de acordo com o mesmo pensamento, que se uma pessoa não sente culpa porque não aprendeu a discriminar as contingências necessárias para tal, é possível que ela aprenda a discriminar as contingências e passe a nomear o sentimento de culpa, que pode ser um inibidor para comportamentos que prejudiquem outras pessoas por exemplo. O processo semelhante poderia explicar o não reconhecimento da vergonha e conseqüente expressão, bem como a maneira como poderia ser aprendida por indivíduos cuja falta de vergonha implica em prejuízo àqueles que o cercam.

Lewis (1993) define que a culpa é um estado emocional que ocorre quando a pessoa avalia negativamente seu comportamento, mas pode livrar-se desse sentimento se realizar uma ação que repare a ação negativa. Isto se chama de reparação. Já a vergonha não é produzida por nenhum evento específico, mas pela interpretação que o indivíduo faz de uma situação e por isso uma vez que sinta vergonha, a pessoa não pode reverter este sentimento.

De La Taille (1997) explica que na culpa, o lugar do outro é de vítima, a pessoa sente culpa perante as pessoas que foram alvo do comportamento condenável. Estas vítimas, caso ofereçam perdão serão as pessoas que aliviarão o sentimento de 
culpa. No caso da vergonha, o lugar do outro é de julgar. A pessoa sente vergonha diante dos olhos que a avaliam e julgam. Não há equivalente ao perdão para a vergonha.

Feldman (1979) diz haver evidência de que os julgamentos morais não são estáveis não dependem apenas do estágio de desenvolvimento alcançado; eles são alteráveis através de técnicas e situações padronizadas. Concluiu Feldman (1979) sobre o desenvolvimento moral que os estágios podem ser sucessivos, mas são adquiridos através da aprendizagem, e pode-se também alterar a direção do desenvolvimento por meio de experiências de aprendizagem adequadas. Tanto o ritmo quanto $o$ acontecimento de mudança não são imutáveis, dependem de experiências específicas. Sendo assim, torna-se possível acreditar que é aprendida, e portanto passível de ser ensinada, a capacidade de realizar julgamentos morais no repertório de um individuo.

Estando claro que é possível observar que os adolescentes infratores de alto-risco não apresentam julgamento moral que os leve a sentir vergonha e culpa, é possível também supor que o processo de psicoterapia no qual o psicoterapeuta munido da análise funcional e do conhecimento desta teoria acerca do desenvolvimento moral poderá modificar esta falta de julgamento moral do infrator. A aquisição da capacidade de reconhecer estes sentimentos de vergonha e culpa e a sua expressão certamente são objetivos de uma psicoterapia com infratores.

Sobre o comportamento inadequado do infrator de culpar outras pessoas pelos próprios atos, livrando-se da responsabilidade, Gibbs (1991) relata que o adolescente típico com uma desordem de conduta anti-social possui falhas no desenvolvimento sócio-moral de forma que torna evidente um grau desordenado de tendência hedonista e um julgamento moral imaturo. $\mathrm{Na}$ base do atraso de desenvolvimento sócio-moral estão certas distorções cognitivas, especialmente a externalização (atribuição) da culpa e a rotulação errônea. Esta característica é bastante 
observada em adolescentes infratores de alto-risco: não se responsabilizam pelos próprios atos, culpando os outros pelas próprias infrações, por exemplo, matou determinada pessoa porque ela merecia, a culpa era da vítima porque ela fez alguma coisa que não era para fazer.

Passando para os comportamentos desejáveis ou adequados, o grupo de comportamentos pró-sociais são objetivos da ressocialização por serem incompatíveis com os comportamentos ligados à reincidência criminal. São eles: auto-revelação, expressões de arrependimento e expressão de sentimentos positivos.

Para que qualquer um destes comportamentos possa aparecer no processo terapêutico é preciso que se estabeleça o sentimento de confiança na relação terapêutica. Confiança é um sentimento que está ligado aos conceitos de vínculo e apego.

Bowlby (1984) descreve que a ligação entre falta de vínculo e crime é proporcionada pelo fato de que a falta de apego prejudica a capacidade para constituir relações afetivas com os outros. Desta forma, os outros podem ser prejudicados sem remorso, ou culpa.

Para Feldman (1979) em linguagem operante, a falta de apego equivale à ausência de reforços positivos e é sentida como algo aversivo. Quanto mais constante e regular for a falta de vínculos afetivos, mais aversiva se tornam as possibilidades de apego. Isto explicaria a dificuldade marcante de fazer e manter vínculo no processo terap6eutico com infratores.

O papel do vínculo com o psicoterapeuta no processo de ressocialização do adolescente é inicialmente de um lócus de controle externo. "Em qualquer tipo de sociedade, quando há pouco vínculo, não há afeto a perder, de forma que não há 
sustentação para que a carência afetiva exerça uma influência controladora sobre o comportamento" (Feldman, 1979, p.83). Ou seja, quando há afeto através do vínculo o adolescente infrator pode não se comportar de forma anti-social afim de preservar esta relação, o que significa dizer que o comportamento dele ainda está sob controle de contingências externas (aprovação do outro). Porém desta vez contingências que não estão ligadas ao crime. Este seria um dos primeiros passos no caminho da ressocialização.

Mas como de fato é bastante presente esta dificuldade em formar vínculos de afeto, o infrator dificilmente terá aprendido a fazer a leitura dos sinais sociais de desconforto, por exemplo, o que mostra que não adquiriram em seu desenvolvimento o sentimento de empatia, além dos já citados de vergonha e culpa. Hoffman e Satzstein (1967 apud Feldman 1979) enfatizam a importância da empatia como recurso emocional, o que acrescenta a dor que se sente quando se faz mal a outra pessoa à necessidade de amor, aumentando assim a urgência da aprendizagem de regras e de controle do comportamento. "As técnicas de educar pelo afeto, enfatizando respostas positivas, substituem mais eficazmente as transgressões por respostas alternativas socialmente desejáveis. As pessoas treinadas através do afeto mostram-se mais inclinadas a assumir responsabilidade tanto por redimir-se das transgressões como por evitá-las no futuro" (Feldman, 1979, p.87).

Quando Feldman (1979) descreve o processo de socialização como uma reação à transgressão, ou seja, como forma de tratamento para o comportamento infrator, ele explica as três reações contingentes aos comportamentos sociais e de aprendizagem que são relevantes para o desenvolvimento de um repertório incompatível com o infrator: a autocrítica, a reparação e a confissão (nesta ordem). 
A autocrítica é adquirida pela criança através das associações vivenciadas entre o elemento verbal de uma punição e a terminação de sua ansiedade antecipatória através de uma resposta verbal pronta e desejável. "Em igualdade de condições, um relacionamento afeiçoado resulta em maior associação de ansiedade com a punição pela transgressão - daí uma redução maior de ansiedade pela autocrítica. Assim, um relacionamento afeiçoado, incentiva indiretamente o desenvolvimento de reações de autocrítica" (Feldman, 1979, p.80-81).

A reparação é de natureza corretiva e está relacionada à percepção do efeito de uma transgressão sobre os outros. Fica mais evidenciada quando há restituição por dano material. Porém, na base da reparação estão o afeto ou a preocupação pela vítima. Segundo Wallace e Sadalla (1966 apud Feldman, 1979) a reparação por vezes toma a forma de comportamentos irrelevantes para a infração em si, como, por exemplo, realizar uma tarefa desagradável determinada pelo juiz.

A confissão ou revelação do crime é um informe verbal do próprio feito infrator. Para Feldman (1979) é possível que um relacionamento afeiçoado, uma declaração de intenção de não repetir o ato, e a apresentação de respostas alternativas, assim como os reforços positivos para a adoção de tais alternativas, sejam todas condições necessárias e desejáveis para uma confissão com vistas à redução da reincidência. A revelação pode produzir ou evita um castigo, dependendo da resposta da pessoa a quem a confissão for feita. Se for seguida apenas por castigo exterior, parece menos provável que seja usada futuramente, diferentemente de se o castigo conseqüente for menos grave do que a punição final após a descoberta de uma infração nãoconfessada. 
$\mathrm{Na}$ experiência com adolescentes infratores de alto-risco no programa da Dra. Paula Gomide a sucessão destas reações parecia iniciar com a revelação ou confissão, seguida da autocrítica verbalizada e então a reparação, quando possível.

Jovens anti-sociais possuem uma orientação autocentrada típica que deve ser compreendida primariamente em termos do atraso no desenvolvimento sócio-moral ou se já, persiste para além da infầncia um pronunciado grau de "tudo-eu" ou tendência egocêntrica, bem como um julgamento imoral imaturo. A tendência egocêntrica é uma marca natural do pensamento e do comportamento na tenra infância.

Na medida em que a atenção situacional social da criança se torna mais extensiva, igualmente distribuída e balanceada, ou seja, na medida em que a descentralização social vai aparecendo, a tendência egocêntrica tende a declinar. Prescrições de justiça ou reciprocidade surgem, primeiramente em termos pragmáticos.

Saindo do estágio do egocentrismo, a criança adentra uma nova etapa onde valoriza normas e leis de propriedades. Nesta etapa aprende-se por exemplo a não roubar ou tirar alguma coisa de alguém que é considerado legal, ou que poderá descobrir esse vingar.

O estágio três de julgamento moral é menos submetido a tendência egocêntrica. Neste e no próximo estágio de desenvolvimento, características considerando os sentimentos de outras pessoas e expectativas legítimas no contexto de relacionamentos valorosos e mútuos. Nestes estágios considera-se errado tirar vantagem de outras pessoas.

Comparando infratores a adolescentes "normais" encontram-se porcentagens significativamente mais altas de infratores no segundo estágio de julgamento moral do que em estágios mais maduros. 
Particularmente quando a ameaça aos outros é óbvia e difícil de ignorar o jovem engajado em comportamento anti-social pode encontrar a tensão psicológica de: a) culpa incipiente a partir da empatia gerada por dicas de expressão da vítima, e b) dissonância cognitiva entre um comportamento que é injustificavelmente prejudicial aos outros e um autoconceito de quem não prejudica os outros injustificadamente. O jovem anti-social frequentemente solidifica seu atraso de desenvolvimento sócio-moral com certas distorções cognitivas auto-atribuíveis, pelo menos parcialmente como uma defesa contra estes problemas e potenciais inibidores do comportamento anti-social.

Quando associados com comportamento anti-social grave então o atraso de desenvolvimento sócio-moral é tipicamente mantido por distorções cognitivas. As distorções cognitivas são falsas atitudes ou crenças geralmente autoconstruídas relacionadas à própria pessoa e a seu comportamento social. A tendência egocêntrica por si só em efeito constitui uma postura de ação distorcida no meio social. Desde que as distorções cognitivas autocentradas relacionam-se diretamente com a tendência egocêntrica e podem anteceder outras distorções; podem ser chamadas de distorções primárias.

As distorções cognitivas secundárias são chamadas de racionalizações e servem a uma função defensiva. Estas racionalizações neutralizam a empatia e a dissonância e desvinculam o ato anti- social realizado de conseqüências autoavaliativas. Como resultado, o julgamento imoral imaturo, a tendência egocêntrica e o egoísmo podem continuar a desencadear comportamento anti-social.

No trabalho com adolescentes anti-sociais, Gibbs (1991) se deparou principalmente com duas categorias de racionalização: a externalização (atribuição da culpa) e a rotulação equivocada. Também verificou que antes de um ato hostil o jovem aparentemente se engajava em um pensamento distorcido, atribuindo gratuitamente 
intenções hostis à outra pessoa, ou seja o adolescente justificava através do outro a agressão que ele mesmo cometia.

Indivíduos anti-sociais tendem a se considerar mais como vítimas do que como vitimizadores. Infratores podem ver seus crimes como a correção de uma injustiça infligida à eles, a correção de uma desigualdade ou algo merecido de fato ou em sua imaginação. As distorções cognitivas destes jovens também acabam por protegê-los de uma culpa baseada na empatia por ter prejudicado a vítima.

A rotulação equivocada é uma construção tendenciosa de representações ou interpretações a cerca do comportamento de alguém e de seus efeitos. Tal como na atribuição da culpa a rotulação equivocada permite ao jovem anti-social escapar psicologicamente da responsabilidade ou pelo menos reduzir a dissonância cognitiva e a neutralizar a culpa com base na empatia.

Então de maneira geral o atraso no desenvolvimento sócio-moral característico do jovem infrator está frequentemente associado com sua forma distorcida de pensar. Quando este atraso está associado com comportamento anti-social grave é provável que a atribuição da culpa e os erros $\mathrm{d}$ interpretação tenham protegido $\mathrm{o}$ indivíduo de forma bem sucedida $\mathrm{d}$ alguns potenciais estresses inibidores gerados pelas antecipações ou pelas conseqüências do comportamento infrator (empatia pela vítima, dissonância com o autoconceito).

Em termos teóricos o atraso no julgamento moral pode ser suprido por uma concentração de oportunidades programadas para estimular o desenvolvimento a níveis apropriados de julgamento moral. Aos adolescentes é dada a oportunidade de considerar as perspectivas alheias frente às próprias perspectivas, seja num contexto de intervenção de grupo ou em uma estratégia individual. Tanto em uma quanto em outra o foco são os dilemas morais. Os participantes devem relatar e justificar sua resolução de 
problemas face aos desafios. As discussões não devem apenas ser de cunho moral, abordagens terapêuticas que facilitam a coesão de grupo, a empatia e as habilidades sociais também devem ser utilizadas.

Pra se tratar a atribuição da culpa poderá ser utilizada a técnica de reversão que implica em devolver a responsabilidade pelo ato a quem necessita de mudança, ao invés de projetá-lo para outras pessoas. Outra técnica é a de confrontar, tornando o jovem consciente dos efeitos de suas ações sobre os outros. Confrontar direciona a tensão do adolescente para compreensão da ameaça aos outros como resultante de suas próprias ações e portanto é uma técnica que desencadeia e fortalece resposta empáticas.

\section{Vergonha e Culpa}

Vergonha e Culpa são nomes dados aos relatos de comportamentos verbais encobertos, chamados de sentimentos, que estão associados ao desenvolvimento do comportamento moral. Ambos estão relacionados à apresentação ou à ausência de comportamentos anti-sociais, pois servem como fortes inibidores de atos inadequados, refreando a emissão de comportamentos que foram no passado correlacionados a conseqüências punitivas.

Em Beyond Freedom and Dignity, Skinner criticou o conceito mentalista de culpa, porém se faz necessário tentar compreender este termo de um ponto de vista analítico-comportamental devido à sua relevância nas relações humanas.

Se uma criança pega escondido dinheiro da carteira da mãe e este ato quando descoberto for consequenciado pelos pais com a proibição de brincar no playground com os amigos por uma semana. E ainda, se esta proibição for associada com uma preleção que favoreça a autocrítica da criança, mostrando-lhe que enganou os 
pais, lhes causando desgosto, provavelmente a estimulação aversiva ligada à culpa e à vergonha será suficiente para que a criança evite passar pela mesma situação no futuro.

Os seres humanos aprendem desde cedo a discriminar estados corporais próprios da interação do organismo com eventos ambientais. Aprendem com a comunidade verbal a nomear esses estados com nomes de sentimentos. Vistos desta forma, os sentimentos, tal como os comportamentos, são funções das contingências de reforçamento em operação.

Seguindo esta linha de pensamento, Skinner (1953) afirma que aquilo que chamamos de vergonha e culpa são produtos resultantes do controle comportamental exercido pelas agências controladoras (governo e educação, por exemplo) e seus representantes (lei e família, respectivamente).

Este controle, chamado de "controle ético" define comportamentos em termos de certo e errado, bom e mau, legal e ilegal. Os grupos sociais tornam punições contingentes a determinados comportamentos com o objetivo de reduzir a probabilidade de nova ocorrência do mesmo, porém, como explica Skinner (1953), é improvável que a punição per se enfraqueça o comportamento. O que ocorre é a produção de estímulos aversivos condicionados, dos quais alguns efeitos serão associados pelo sujeito à vergonha, por exemplo, de algo com significado para aquele grupo social.

Charles Darwin (1872 apud Araújo, 1999) é considerado o pioneiro no estudo científico da vergonha no comportamento humano. O biólogo acreditava ser este sentimento "o mais peculiar e o mais humano de todas as expressões, e que seu surgimento dependia de dois elementos: a reflexão sobre si mesmo de alguma característica de aparência pessoal; e o pensamento sobre o que os outros pensam de nós". Da mesma forma, Araújo (1999), diz que se pode considerar a vergonha um dos 
sentimentos mais relevantes para a experiência humana com o mundo, sendo ela um regulador nas relações interpessoais e intrapessoais.

La Taille (2002b) procura explicar que a vergonha pressupõe também um controle dito interno: quem sente vergonha julga a si próprio. O que pode ser descrito em termos de estímulos aversivos condicionados pela comunidade verbal com a qual o indivíduo interage. Wilson, Drozdek e Turkovic (2006) também reconhecem os aspectos interno e externo da vergonha. Eles dizem que, a vergonha externa está associada com uma ansiedade social e relacionada com uma preocupação do sujeito de como os outros julgarão seus atos. Já a vergonha interna vem acompanhada de sentimentos de inferioridade, desgosto, invalidação, fraqueza e inadequação.

A experiência da vergonha está relacionada a uma auto-avaliação sobre o comportamento que é considerado desonroso.

Araújo (1999) expõe que, na psicologia, quando a vergonha não é desconsiderada, ela é geralmente vista como um sentimento acoplado à culpa. Apesar de poderem se manifestar juntos, são sentimentos de natureza distinta. La Taille (2002a) coloca que a culpa, por ser um sentimento interno por excelência, no sentido de não ser desencadeado pelo julgar do outro, é um sentimento moral básico.

A culpa é uma forma de mal-estar ou desconforto emocional baseado em relações interpessoais que motivam e encorajam comportamentos pró-sociais. É um estado emocional provocado e desprazeroso que origina-se a partir de uma crença de que a pessoa está se comportando incorretamente ou de que a estão julgando como se ela estivesse agindo erroneamente (Lazarus, 1991; O’Keefe, 2000; Baumeister, Stillwell \& Heatherton, 1994 apud Lindsey et al., 2007). 
Guilhardi (2002) considera que a culpa envolve uma poderosa comunidade formada pelos pais, professores, governo, sistema judiciário, entre outros, que categoriza um dado comportamento como ilegal e o pune de acordo com as regras do grupo social ou com a lei. Desta forma, quase sempre se desvia o foco do comportamento e considera-se a pessoa, ao invés do comportamento, culpada. Sendo assim, as contingências de reforçamento são estabelecidas de forma que, caso a pessoa emita um "comportamento aversivo para a comunidade, os membros desta, sob controle aversivo", julgam, avaliam "o comportamento do indivíduo como inadequado e o consequenciam emitindo comportamentos funcionalmente aversivos para o indivíduo. (...) Responsabilizam a pessoa pelo que ela fez. (...) Assim, o pai (juiz) avalia (julga) o filho como responsável (culpado) pelo comportamento que é aversivo ao pai (delito)" (p. 178).

Ingberman e Machado (2003) diferenciam o culpar-se e o sentir-se culpado. O culpar-se implica no reconhecimento da infração de uma regra previamente estabelecida em uma relação e na provável punição subseqüente, pública ou privada. Já o sentir-se culpado abrange processos respondentes condicionados na história de aprendizagem do indivíduo, que explicam a variedade de sensações associadas ao relato do sentimento de culpa, como vontade de chorar, tristeza, ansiedade, aperto no peito, fadiga, enfraquecimento das pernas, apatia, dor de cabeça, entre outros.

La Taille (2002a) também faz a diferenciação das expressões "culpar-se" e "sentir-se culpado". Segundo ele, atribuir a culpa a alguém é dizer que esta pessoa é responsável por um evento considerado negativo, por exemplo, o treinador teve culpa pela derrota do time, e não é dito que ele foi culpado por evento positivo, comopor exemplo uma vitória do time. Apesar de se reconhecer como responsável pelo evento, a 
pessoa pode não sentir-se culpada. Para sentir-se culpada, a pessoa deve não apenas reconhecer que foi autora de uma ação, mas sentir-se mal por tê-la realizado.

As ações reparativas ocorrem quando o culpar-se "é evocado por contingências punitivas arranjadas pela sociedade" (p.243), ou seja, gastar dinheiro usufruindo de bens que os outros não podem ter, é um comportamento que pode ser reprovado pelo contexto, fazendo com que o indivíduo que se culpa empreenda situações reparativas, eliminando os estímulos aversivos ligados à situação. Nas respostas de desculpabilização a responsabilidade é atribuída ao ambiente, sendo reforçada por evitar a punição. E as ações autopunitivas se dão quando o sujeito infringe a si próprio uma condição aversiva “como forma de quitar uma 'divida pendente' por um erro" (Ingberman \& Machado, 2003, p.243).

Ingberman e Machado (2003) explicam o condicionamento dos comportamentos aversivos, tanto de sentir culpa quanto do culpar-se, expondo que estes fazem parte de aprendizagens relacionadas às condições pelas quais o indivíduo passou durante a infância. Por exemplo, quando a criança comete um erro, os pais a punem exageradamente no que diz respeito à relação adequada entre o comportamento e a conseqüência diante da situação. Outra forma de aprendizagem destes comportamentos são os princípios morais injetados no mundo da criança através das histórias infantis que projetam padrões ideais de valores, muitas vezes impróprios ao cotidiano, sendo que, nestas estórias, fazer a escolha errada significa ser severamente punido. De modo semelhante, para Yau-Fai Ho, Fu e Ng (2004), a culpa é acompanhada do medo de punição de figuras de autoridade ou por retaliação de adversários mais poderosos.

Segundo Baum (1999), atribuir a culpa ao ambiente é um comportamento operante, principalmente verbal, que é reforçado por evitar punição. Ele diz que as pessoas inventam vários tipos de desculpa para seus atos vergonhosos com o 
objetivo de atribuir a culpa a alguma outra coisa, ou seja, atribuem causas do comportamento ao ambiente. Para ele, a culpa é uma outra forma de se falar em causas como o componente adicional da desaprovação. As ações censuráveis são punidas (p.193).

Tracy e Robins (2006) diferenciam vergonha e culpa explicando que esta acontece quando o foco está sobre aspectos negativos do comportamento, e aquela é experienciada quando o foco incide sobre o indivíduo. Ambas seriam causados por atribuições internas, mas a culpa aparece quando comportamentos são acusados, e a vergonha quando a pessoa é acusada.

As atribuições referem-se aos valores e regras aprendidas pelos indivíduos. De acordo com Araújo (1999), é nas interações sociais da criança com o mundo, principalmente com a família, que os valores e regras vão sendo construídos e internalizados. A família, além de estabelecer as regras para os comportamentos, atribui uma valoração para estas, e através do vínculo e/ou pela identificação estabelecida entre as pessoas envolvidas, a transgressão dessas regras, ou as ações contrárias aos valores estabelecidos podem eliciar o sentimento de vergonha, caracterizado como uma vergonha moral. Portanto, o sentimento de vergonha pode ser compreendido como um sentimento moral quando estiver relacionado com a regulação intra e interpessoal estabelecida a partir de conteúdos de natureza moral.

A literatura vigente apresenta várias pesquisas realizadas sobre os sentimentos de vergonha e culpa e sua relação com o comportamento moral (Tracy \& Robins, 2006; Lindsey et al., 2007; Stuewig e McCloskey, 2005; Ahmed \& Braithwaite, 2006) .

Tracy e Robins (2006) fizeram uma avaliação dos antecedentes da vergonha e da culpa. O estudo foi dividido em quatro partes. Na primeira parte foram 
testadas três hipóteses examinando a relação entre as diferenças individuais crônicas em estilos característicos, a tendência à vergonha e a tendência à culpa. Participaram deste estudo 153 indivíduos, sendo 70\% mulheres. Os resultados mostraram que a tendência à culpa está associada às atribuições internas da pessoa, enquanto que a tendência à vergonha tem correlação tanto com as atribuições internas quando com as externas, isto porque, segundo os autores, as atribuições internas têm antecedentes cognitivos para a vergonha e as atribuições externas são os componentes cognitivos usados para regular este sentimento. Também foi possível observar que a vergonha está positivamente correlacionada com fatores ambientais estáveis e incontroláveis, enquanto que a culpa relaciona-se positivamente com fatores instáveis e controláveis.

As descobertas feitas por Tracy e Robins (2006) sustentam três pontos derivados do modelo teórico do conhecimento dos sentimentos de vergonha e culpa. Todos os estudos destes autores mostraram que as atribuições internas guiam o reconhecimento das emoções. Ou seja, quando as pessoas culpam-se por um fracasso (atribuição interna), elas experienciam vergonha. Os estudos mostraram que a tendência à vergonha regula esta dolorosa emoção através da culpabilização do outro pelo fracasso. Eles também têm implicações na maneira que a culpa é regulada, eles sugerem que os indivíduos não regulam sentimentos de culpa através de fatores externos. A culpa é considerada mais eficiente através da regulação do comportamento do que pela cognição. Foi possível concluir também que quando o fracasso tem causa interna e incontrolável como a habilidade, ele tem relação com a vergonha e quando este fracasso tem causa interna e controlável, como o esforço, está relacionado com a culpa. Com isso os autores mostraram que tanto a vergonha quanto a culpa relacionamse com atribuições internas feitas pelo indivíduo em relação ao evento eliciador do 
sentimento, porém, a vergonha surge quando a pessoa não tem o controle sobre a situação, e a culpa quando a situação poderia ser controlada, mas não foi.

O sentimento de vergonha não é produzido por um evento específico, mas por uma interpretação que o individuo faz da situação vivida, sendo que uma vez sentida a vergonha não há possibilidade de revertê-la. Já a culpa é um estado emocional relacionado a uma avaliação negativa que o individuo faz do seu comportamento.

\section{Mentira}

A mentira tem sido estudada por analistas do comportamento como um comportamento operante verbal.

Segundo definição do dicionário Houaiss a palavra mentira refere-se ao ato ou efeito de mentir; "engano, falsidade, fraude; hábito de mentir; afirmação contrária à verdade a fim de induzir a erro; qualquer coisa feita na intenção de enganar ou de transmitir falsa impressão; pensamento, opinião ou juízo falso; aquilo que é enganador, que ilude, que se aproxima da verdade ou é real apenas na aparência; ilusão, fábula, ficção".

A mentira é parte do cotidiano da sociedade e está presente desde os mais altos escalões governamentais até as mais retiradas tribos. Neste capitulo será descrito e discutido o conceito de mentira, analisando seus possíveis antecedentes comportamentais e as conseqüências de sua utilização, bem como os tipos, os aspectos fisiológicos e psicológicos, a mentira na infância, a aprendizagem por meio de modelos e as patologias associadas à mentira.

Para Smith (1953) a mentira é qualquer comportamento que tenha a intenção de fornecer às pessoas informações falsas ou privá-las das verdadeiras. Já para 
Ballone (2006), a mentira é mais uma maneira de enganar alguém, não contando para isso o teor e a amplitude da deturpação da verdade. Juridicamente, é ligada ao dolo (intenção) de prejudicar alguém com tal informação, como o falso testemunho.

Como definido por Ballone (2006) a mentira não é apenas uma invenção ou criação, pois nem toda invenção ou criação é uma mentira, como nos casos da literatura, da arte ou até mesmo da demência. O que define se algo é mentira, é o dano ou dolo. Segundo o autor, a mentira não é apenas uma invenção deliberada, pois não podemos considerar mentira a arte e os filmes apenas porque não são verídicos; para ele a mentira seria dirigir a alguém algo falso, desde que quem a conta saiba que é falso.

Seguindo esse raciocínio, vale ressaltar o pensamento de Santo Agostinho citado por Ballone (2006) que disse que quem anuncia algo que the parece verdade ou que realmente acredita, não está mentindo, mesmo que aquilo não seja verdadeiro.

Partindo da citação agostiniana é possível expor uma definição analíticocomportamental de mentira tal como um comportamento operante verbal que não possui correspondência com as contingências de fato compreendidas no fato descrito.

Pergher e Sadi (2003) explicam que sob a perspectiva da análise do comportamento o que uma pessoa fala não condiz necessariamente com os eventos que supostamente estão sendo descritos. Isto significa que aquilo que é dito pode ou não estar de acordo com os estímulos antecedentes (Skinner, 1978) Para uma compreensão dos conceitos de verdade e mentira sob uma ótica analítico-comportamental, há que se definir alguns conceitos skinnerianos relacionados aos operantes verbais.

Para Skinner (1978) um tato é um operante verbal no qual uma resposta de certa maneira é evocada por um objeto ou evento particular, ou por uma propriedade de um objeto ou evento. E o mando é um operante verbal no qual a resposta é reforçada 
por uma conseqüência própria e está sob controle funcional de condições relevantes de privação ou estimulação aversiva.

"Quando o que se fala condiz com o que se faz, dizemos que o relato verbal está sob controle dos estímulos antecedentes e que o comportamento verbal corresponde ao comportamento não verbal. Mas quando o que se fala não condiz parcial ou totalmente - com o que se faz, dizemos que o relato verbal está sob controle de conseqüências especiais e que o comportamento verbal não corresponde ao comportamento não verbal (Pergher e Sadi, 2003, p.148).

Desta forma, pode-se definir a mentira como um operante verbal que não corresponde com o comportamento não verbal, o evento. Já a verdade seria a relação de correspondência entre o comportamento verbal e o evento ocorrido.

Já em seus primeiros escritos sobre o comportamento verbal Skinner $(1957,1978)$ alertava para o fato de que o controle de estímulos sobre o comportamento verbal muitas vezes não é ideal, e que o relato verbal pode ser aumentado, distorcido ou exagerado. Nos interessa saber portanto o que mantem este operante verbal no sentido de alterar a correspondência entre o que de fato ocorreu e o que é relatado.

Conseqüências reforçadoras especificas (receber atenção, evitar punição) podem controlar o relato, mais especificamente, o comportamento de mentir pode estar sob controle de conseqüências que o individuo visa.

Portanto, uma análise da mentira deve envolver a investigação de conseqüências reforçadoras positivas que possam estar sendo contingentes a determinadas respostas verbais, ocasionando com isso a não correspondência"(Pergher e Sadi, 2003, p.149).

Os mesmos autores exemplificam descrevendo que quando um pescador superestima o tamanho do peixe apanhado, o relato não está sob controle de eventos 
antecedentes (o tamanho real do peixe), mas de consequencias reforçadoras especificas, por exemplo, o pescador passa a ser admirado. Neste caso o relato verbal assume função de mando, "pois pescar peixes grandes é uma tarefa para um pescador experiente e habilidoso"(p.149), e desta forma ele adquire maior admiração e status em seu grupo.

Um interessante estudo sobre as mentiras presentes diariamente em nossas vidas foi realizado por DePaulo e Kashy (1998). Nesse estudo, eles encontraram que a mentira é usada como ferramenta para mostrar confiabilidade, preocupação e respeito. Os autores citam que para demonstrar sua preocupação e amor, as pessoas elogiam seus amados, concordam com suas intenções (mesmo que não concordem realmente) e afirmam ter entendido um ponto de vista, com o qual não concordam. A meta-mensagem (como definida pelos autores) passada por aqueles que mentem é a de que eles se importam mais com os sentimentos daqueles com quem interagem, do que propriamente com a verdade. DePaulo e Kashy (1996) também afirmam que a mentira pode ser utilizada para conseguir objetivos sociais, tais como adquirir amigos ou uma maior influência sobre as pessoas.

DeFraine (1997) encontrou que muitos casos do que ela chamou de Mentira Pessoal têm base na infância das pessoas. Quando crianças buscavam atenção dos pais com manhas e atitudes chamativas. Nesse cenário, os pais cediam às atitudes das crianças. Isso em longo prazo influenciou essas crianças a tornarem-se pessoas que necessitam de atenção para se sentirem bem, utilizando-se das mentiras pessoais para tanto. Essas mentiras foram separadas em dois grupos, as que tentavam engrandecer a pessoa do mentiroso (contando fatos como prêmios, conquistas que na realidade não tinham alcançado) e aquelas que fragilizavam a figura do mentiroso (doenças, falta de recursos, dentre outros). Desse estudo pode-se extrair que, diferente do que se imagina, as mentiras contadas podem não ter relevância, pois no que foi demonstrado, as 
mentiras podem ter caráter ligado à aprendizagem da pessoa, inclusive, em sua necessidade por atenção e o sentimento de inferioridade que possuem.

Para Ballone (2006) o quadro mais grave em que a mentira aparece como sintoma é o Transtorno Anti-Social da Personalidade (T.A.S.P.). O autor difere a mentira banal da psicopática, sendo que o psicopata (termo popularmente utilizado para o T.A.S.P.) usa a mentira como uma ferramenta. De tão habituado a mentir, é difícil a detecção de suas falsidades, inclusive, ele mente olhando nos olhos das pessoas, neutra e relaxadamente. Destaca ainda que o psicopata sabe que está mentindo, não se importando, tendo vergonha ou qualquer arrependimento. Usualmente, segundo Ballone (2006) a pessoa portadora do T.A.S.P. diz o que é perfeitamente conveniente e adequado para uma circunstância. O autor ressalta ainda a habilidade do psicopata em mentir com o corpo, teatralizando algumas situações favoráveis a ele, mascarando ou simulando sentimentos e situações, que podem chegar à insinuação de um suicídio.

\section{Aplicação das Práticas Educativas na Sessão Terapêutica}

Uma avaliação cuidadosa do adolescente e quando possível de sua família, proporcionará ao psicoterapeuta informações relevantes e necessárias para a escolha dos componentes apropriados para o plano terapêutico (Southam-Gerow \& Kendall, 1997). A absoluta maioria das famílias de adolescentes infratores demonstram padrões de interação coercitivos, violentos e/ou negligentes (Patterson et al, 1992; Tolan e Gorman-Smith, 1997; Southam-Gerow \& Kendall, 1997; Reid e Eddy, 1997). Este padrão de comportamento não pode se repetir nas interações entre psicoterapeuta e cliente-adolescente infrator. 
A literatura discute a importância do comportamento do psicoterapeuta focalizando variáveis em termos de características possíveis de se inferir a partir da relação terapêutica (Meyer \& Vermes, 2001; Kohlenberg e Tsai, 2001; Beck, 2007).

Adolescentes infratores apresentam dificuldades claras de submeter-se a regras e respeitar limites (Patterson et. al 1992; Gomide, 1999). É certo que o déficit de supervisão está relacionado ao desenvolvimento de comportamento anti-social (Reid \& Patterson, 1989; Snyder \& Patterson, 1987; Gomide, 2003a), logo, o uso desta prática se faz imprescindível no manejo com o adolescente, inclusive sendo possível fazer uso de medidas disciplinares previamente estabelecidas quando regras e combinados não são cumpridos. Isto é particularmente importante no trabalho com infratores institucionalizados, pois demonstra claramente a consistência do comportamento do psicoterapeuta em especial, mas de todos os profissionais que ali trabalham, em relação ao seguimento de regras, fornece modelo adequado sinalizando que uma relação de respeito e afeto também requer estabelecimento de limites claros. Esta situação pode ser ilustrada imaginando-se uma situação na qual um adolescente se negasse a ir para a psicoterapia. Como todas as negativas de comparecer a uma atividade, esta também seria sancionada com a perda de todas as atividades durante vinte e quatro horas, seguindo as normas disciplinares da instituição. Porém, quando o adolescente retornasse para o processo, sua negativa, ao invés de questionada, deveria ser acolhida pelo psicoterapeuta que deveria mostrar querer compreender a função da não vinda à terapia. $\mathrm{Na}$ tentativa de fortalecer o vínculo terapêutico há o risco de que o psicoterapeuta incorra em práticas inconsistentes, fazendo concessões ou "deixando passar" determinadas condutas inadequadas do adolescente. Esta prática pode até contribuir momentaneamente para a relação terapêutica, mas tem os efeitos colaterais 
próprios do esquema de reforçamento intermitente para o comportamento inadequado, além de sobrepujar o modelo moral que deveria ser qualificado.

$\mathrm{Na}$ medida em que o adolescente possa contar coisas e falar espontaneamente ao cuidador sem que este precise persuadi-lo, ele tende a engajar-se menos em comportamentos de risco e conseqüentemente diminui-se a escalada rumo ao comportamento delinqüente (Cernkovich \& Giordano, 1987), sendo reconhecido que infratores têm pobre comunicação e pouca confiança e intimidade com seus pais ou cuidadores. Ainda no que tange à obtenção de informações, o ideal é que elas sejam solicitadas, especialmente quando se referem às amizades. Desta forma é possível colocar regras e descrever contingências sobre as companhias do jovem, diminuindo a necessidade de controle aversivo por parte do cuidador (Wright \& Cullen, 2001; Gomide, 2006). Estes comportamentos de um cuidador aplicam-se especialmente ao psicoterapeuta na situação de internamento de infratores. O profissional possui um momento privilegiado de escuta e obtenção de informações, que além de contribuírem para a compreensão funcional do caso, servem também como matéria prima de autoconhecimento para o cliente.

Outro comportamento que faz parte da prática adequada da monitoria positiva é que o psicoterapeuta aprenda a perceber e interpretar os sinais emitidos pelo adolescente para que possa emitir respostas imediatas e contingentes, facilitando a construção e o fortalecimento de autoconceito do jovem. A literatura do apego (Benda \& Whiteside, 1995; Sokol, Ktaz, Dunham, \& Zimmerman, 1997) indica que mães inábeis em estabelecer o apego seguro estão relacionadas a filhos infratores com baixo autoconceito, logo a ausência do apego é um dos preditores da delinqüência e o estabelecimento de vínculo com o psicoterapeuta pode ajudar na obtenção de resultados positivos. 
Para Gomide (2003) a relação entre monitoria positiva e comportamento anti-social existe não porque a vigilância reduz o comportamento anti-social, como sugerem alguns autores, mas porque a revelação do jovem é representada como "monitoria", e o jovem que fala abertamente e conta com o afeto e compreensão de seus pais tende a cometer menos atos anti-sociais, além de existirem indicativos de que também se diminuem os índices de hábito de fumar, uso de drogas e comportamentos infratores (Cavell, 2000; Stattin \& Kerr, 2000; Pettit \& Bates, 1989). Desta forma, a monitoria positiva na psicoterapia parece promover a auto-revelação ao mesmo tempo em que inibe comportamentos indesejados.

O comportamento moral relaciona-se aos comportamentos participantes na transmissão de valores, tais como: honestidade, generosidade, justiça, compaixão, amizade entre outros, para a inibição do comportamento anti-social (Gomide, 2003). O adolescente infrator pode encontrar estes modelos de valoração no psicoterapeuta, que pode inclusive fazer uso da auto-revelação para ensinar valores socialmente esperados do adolescente e que contribuirão para a construção de um repertório comportamental pró-social.

Schlinger (1995) define que para a análise do comportamento a moralidade é um comportamento que depende das contingências de reforçamento e punição em dada circunstância social, sob determinadas variáveis. Esta definição deixa claro que o psicoterapeuta não deverá apenas mostrar reconhecimento ou auto-revelarse para fornecer modelos morais ao adolescente, mas o seguimento de regras e estabelecimento de limites são também representativos de comportamentos morais.

Se as práticas educativas negativas dos pais possuem efeitos sobre o desenvolvimento de comportamentos anti-sociais, parece razoável entender que da mesma forma, se utilizadas pelo psicoterapeuta, podem fomentar ou manter padrões de 
comportamentos indesejáveis. A prática educativa "disciplina relaxada" é caracterizada pelo não cumprimento de regras estabelecidas (Gomide, 2006). Os pais estabelecem as regras, ameaçam e quando se confrontam com comportamentos opositores e agressivos dos filhos abrem mão de seu papel educativo, retirando-se da situação conflituosa (Gomide, 2003, 2004).

Estabelecer um contrato terapêutico e não cumpri-lo, solicitar tarefas e esquecer de cobrá-las, definir metas terapêuticas e não se reportar às mesmas, prometer algo e não cumprir e até mesmo acobertar comportamentos passíveis de sanções disciplinares do adolescente interno são sinais da prática da disciplina relaxada pelo psicoterapeuta. Os efeitos sobre o comportamento do adolescente poderão ser os mesmos descritos na literatura que trata dos cuidadores que utilizam a disciplina relaxada, e é importante salientar que neste caso especificamente já se tratam de jovens com condutas anti-sociais sérias em seus repertórios. Desta forma deixa-se claro ao adolescente que as regras devem ser cumpridas, que deve-se respeitar a autoridade e evitar a manipulação amocional.

Logo, o contrário da prática de disciplina relaxada o psicoterapeuta deverá abordar a orientação e a supervisão que levam a comportamentos pró-sociais do adolescente, que são incompatíveis com uso e abuso de substâncias e comportamentos sexuais inadequados (sem uso de preservativo, etc).

Se por um lado o psicoterapeuta deve se mostrar interessado, e de fato sê-lo, deve ter o cuidado aumentado de manifestar-se de forma adequada, pois facilmente poderá fazer uso da prática chamada monitoria negativa. A utilização desta prática, ao contrário da monitoria positiva, poderia fazer com que o cliente omitisse informações, mentisse e até não viesse às sessões. Esta prática pode gerar uma relação de dependência e fomentar a insegurança das pessoas envolvidas. 
A monitoria negativa também pode ser chamada de supervisão estressante (Gomide, 2004) e é caracterizada pela excessiva fiscalização e quantidade de ordens dadas aos filhos. Conseqüentemente grande parte dessas normas não é seguida facilitando uma relação hostil, insegura e até falsa entre cuidador-criança/adolescente.

No contexto da relação terapêutica, variáveis importantes para o desenvolvimento e manutenção de modelos morais sólidos estão presentes: o calor humano e a afetividade (Kellerman, 2002), importantes variáveis que devem ser foco do psicoterapeuta no estabelecimento do vínculo necessário para o trabalho (Kohlenberg \& Tsai, 2001, Meyer \& Vermes, 2001, Garfield, 1995). Além disso, o modelo de empatia e solidariedade é fornecido constantemente através de comportamentos do psicoterapeuta presentes possivelmente em todas as sessões da psicoterapia.

\section{Programa para Adolescentes Infratores de Alto-risco}

Este programa foi criado pela Doutora Paula I. Cunha Gomide no ano de 2004 para atender adolescentes infratores de alto-risco, com idade entre 14 e 21 anos que estiveram internados na unidade onde se realizou o programa. O programa ocorreu de fevereiro de 2005 a fevereiro de 2007 e atendeu a 37 adolescentes no total.

$\mathrm{O}$ adolescente infrator de alto-risco era assim considerado se fosse de alta periculosidade, ou seja, praticara atos de extrema gravidade (homicídios, latrocínios, patricidios, chefes de gangs, integrantes de facções criminosas), se tivesse se mostrado resistente ao atendimento nas demais unidades do Estado (agressão a funcionários ou outros adolescentes; destruição de celas, liderança em rebeliões) e também se houvesse suspeita de diagnóstico de psicopatia. 
Estes adolescentes infratores foram criados em famílias de risco, que são aquelas nas quais prevalecem as práticas educativas negativas na educação dos filhos, em detrimento das positivas. Também são aquelas que vivem em condições adversas tais como família monoparental, pais usuários de álcool e/ou drogas, pais portadores de doença mental, pais e/ou parentes envolvidos com o crime e pobreza extrema.

O programa desenvolvido para atender estes jovens era composto por diversas atividades que iam desde a recepção diferenciada do jovem na unidade de internamento até atividades específicas para treinar educadores sociais. Eram as atividades que compunham o programa:

- Recepção

- Medidas Disciplinares

- Atividade: Fábula

- Leitura de Livro

- Videoterapia

- Grupo de Habilidades Sociais

- Grupo de Comportamento Moral

- Psicoterapia com especialista

- Escolarização individualizada

- Atividades externas

- Qualificação Profissional

- Grupo para Controle do Estresse do Educador

- Acompanhamento de Egresso.

A seguir serão descritas aquelas estiveram diretamente relacionadas com a atividade de psicoterapia, objeto de estudo do presente trabalho.

\section{Recepção para ingresso no programa}


Era composta por um conjunto de atividades necessárias para a elaboração do plano individual de atendimento do adolescente recém ingresso. Nesta atividade cada membro da equipe da unidade deveria coletar dados específicos e executar tarefas diferenciadas. Abaixo se encontram listadas as tarefas de cada profissional neste procedimento.

- Educadores: Verificar existência de lesões, corte de cabelos e unha; entregar roupas e proceder à leitura de normas da unidade.

- Setor de Psicologia: Coletar dados de histórico pessoal e familiar, infracional, aplicar IEP para avaliar as práticas educativas parentais, e fazer análise da vizinhança onde vivia o adolescente.

- Serviço Social: Verificar situação processual, listar contatos e endereços de familiares e rever as normas da unidade, esclarecendo possíveis dúvidas.

- Setor de Pedagogia: Proceder à avaliação básica e histórico acadêmico.

- Setor de Terapia Ocupacional: Levantar histórico laboral e interesses ocupacionais do jovem.

- Serviço de Saúde: Verificar doenças atuais e histórico, uso de medicamentos e uso de drogas, álcool; conhecer doenças familiares (depressão, alcoolismo, drogadição).

De posse de todos estes dados era construído o Plano de Atendimento do Adolescente, discutido semanalmente na reunião de equipe.

\section{Medidas Disciplinares}

Eram medidas educativas adotadas pela unidade em decorrência de comportamentos inadequados apresentados pelo adolescente, prejudiciais ao seu 
convívio na unidade. Estas medidas se caracterizavam pela restrição do adolescente ao seu alojamento individual. Durante a execução da medida disciplinar o adolescente podia sair apenas para o atendimento psicológico e para atendimento médico ou odontológico emergenciais. A medida disciplinar deve ser diferenciada da contenção, que era um procedimento físico que visava cessar, interromper um comportamento agressivo do adolescente.

Dividiam-se em:

- Medidas Disciplinares Leves (chutar a porta, xingar funcionários - 24 no alojamento sem atividades),

- Medidas Disciplinares Médias (jogar objetos ou líquidos na equipe - alojamento por 7 dias),

- Medidas Disciplinares Graves (quebrar paredes ou depredar patrimônio da unidade, estar com estoque -15 dias ) e

- Medidas Disciplinares Gravíssimas (agredir fisicamente alguém provocando lesão - 21 dias).

As medidas disciplinares passaram a incluir após um ano de funcionamento do programa as Normas para Visitas, que consistiam em procedimentos que compreendiam: cadastro de pessoas, tempo de visita, normas para revista, alimentos permitidos, visitas e telefonemas assistidos, dentre outros.

\section{Fábulas}

Esta atividade tinha como objetivo utilizar as Fábulas para propiciar situações imaginárias onde as Virtudes ou Valores Morais poderiam ser objeto de reflexão. Acontecia em sessões individuais e semanais, a partir da seleção de virtudes especificas a serem trabalhadas. O responsável lia a fábula ou pedia ao adolescente que o fizesse e em seguida discutiam a moral da história. Caso o adolescente tivesse 
dificuldades com a compreensão, outra fábula com a mesma virtude deveria ser lida na semana seguinte. Eram utilizadas por exemplo as fábulas: A lebre e a tartaruga (trabalhar a persistência), A formiga e a cigarra(o valor do trabalho), entre outras. Os responsáveis por esta atividade podiam ser educadores, estagiários ou técnicos.

\section{Leitura de Livros}

Tinha como objetivo estimular o gosto pela leitura, desenvolver vocabulário e estabelecer regras de convivência (ouvir, falar, bons modos, etc). Acontecia em sessões individuais, cerca de três vezes na semana. O livro era préselecionado pela coordenação do programa e deveria ser lido em capítulos. Ao final de cada capítulo o responsável pedia ao adolescente que fizesse a síntese do capítulo e o interpretasse. As sessões eram interrompidas mediante comportamento inadequado do adolescente (xingamento, cobranças, desatenção, etc). O responsável por esta atividade poderia ser o educador, um estagiário ou o técnico.

\section{Videoterapia}

Objetivava utilizar o entretenimento com filmes para reflexão de valores morais e éticos. Os filmes eram selecionados pela equipe técnica e deveriam obrigatoriamente ter valores explícitos e exemplos de comportamento moral. Filmes com conteúdos violentos somente podiam ser usados em sessões de psicoterapia caso necessário, como por exemplo o filme "Voltando a Viver".

Eram exibidos individualmente ou para dois adolescentes, aos finais de semana, ou à noite. Interessante lembrar que os adolescentes não assistiam à programação de TV nesta unidade.

Alguns filmes utilizados nesta atividade foram: Dois Filhos de Francisco, Coach Carter, O encantador de cavalos, Desafiando os Limites, Diários de Motocicleta, A luta pela esperança, A corrente do bem, De repente 30, Redenção, entre outros. 


\section{Desenvolvimento de Habilidades Sociais}

As atividades de desenvolvimento de habilidades sociais tinham como objetivo desenvolver habilidades não-infratoras de interação social que facilitassem as relações pessoais, escolares e de trabalho. Também eram proporcionados momentos para a aprendizagem de habilidades para lidar com as emoções positivas e negativas, especialmente a raiva.

O procedimento propriamente dito era composto por 12 sessões com aproximadamente duas horas de duração cada. Nestas sessões eram utilizados filmes, ensaios comportamentais, músicas, pinturas, desenhos, argila e colagens, em atividades individuais, em duplas ou trios.

Os responsáveis pelas atividades podiam ser o próprio psicoterapeuta, estagiários de psicologia treinados ou técnicos da unidade especialmente treinados.

\section{Desenvolvimento de Comportamento Moral}

Com o objetivo de desenvolver algumas das principais virtudes (polidez, honestidade, obediência, justiça, empatia, solidariedade, generosidade, amizade, sinceridade) e sentimentos de arrependimento, culpa e vergonha em relação aos crimes cometidos, eram realizadas atividades para o desenvolvimento de comportamento moral.

O procedimento era composto por 12 sessões nas quais eram utilizados filmes, ensaios comportamentais, músicas e desenhos. Podia acontecer individualmente ou em duplas e eram conduzidas por estagiários de psicologia treinados ou técnicos da unidade. 


\section{Escolarização Individualizada}

Visava promover o aumento da escolaridade do adolescente, tendo em vista que estes chegavam na unidade com déficit médio de 7 anos e que para aquisição de um primeiro emprego, este exigiria minimamente o ensino fundamental completo.

As aulas eram individualizadas ou em dupla e ocorriam três ou quatro vezes por semana. Acontecia o estudo programado que era acompanhado por um educador em contra-turno.

O programa atingiu resultados satisfatórios, pois quando foi encerrado $40 \%$ dos jovens internos estavam no ensino médio e tinha sido realizada a formatura de 5 adolescentes no Ensino Fundamental.

\section{Atividades Externas}

Tinham como meta preparar o adolescente para o reingresso ao meio social, treinando, em vivo, habilidades básicas de convivência (esperar na fila, comprar bilhetes, pedir licença, etc). Eram realizadas em teatros, cinemas, zoológicos, museus, estação de águas, lanchonetes, agências de emprego, bancos, faculdades, etc. Os responsáveis poe estas atividades eram a terapeuta ocupacional, educadores sociais, psicólogos e estagiários.

\section{Qualificação Profissional}

Tinha como objetivo preparar o adolescente para a reinserção social através do trabalho. Foram firmados convênios com escolas profissionalizantes, para as quais os adolescentes eram levados assim que fosse avaliada sua prontidão.

Os educadores sociais e terapeuta ocupacional acompanhavam o adolescente ao local do estágio/ atividade e avaliavam diariamente seu comportamento em relação ao trabalho, chefia e aos colegas. 


\section{Acompanhamento de egressos}

Este trabalho consistia em auxiliar os adolescentes egressos da unidade em atividades cotidianas, além de providenciar as condições necessárias de moradia, estudo e emprego dos adolescentes.

Uma das primeiras atividades realizadas era providenciar um local de moradia para os adolescentes. Junto com os mesmos, através de anúncios em jornais e outras indicações, eram selecionados possíveis locais para eles morarem. Após esta préseleção, estes locais eram visitados e avaliados pela equipe formada pela psicoterapeuta, estagiários de psicologia e técnicos da unidade. Analisavam-se condições do local (localização, higiene, demais moradores, privacidade, espaços de convivência), valor do aluguel, e aceitação dos locatários. Definido o local, procurava-se um padrinho, que era alguém que conhecendo o programa oferecia o pagamento do aluguel e ajuda de custos básicos (como alimentação e produtos de higiene pessoal), até que o adolescente conseguisse pagar o próprio aluguel. Os egressos eram auxiliados na mudança e também na organização do local.

Outra atividade realizada, era a procura e a matricula do adolescente em escolas, preferencialmente na proximidade do local de moradia. Os acompanhantes auxiliavam o adolescente com os documentos necessários para a matricula, organização dos horários além de os acompanharem para a realização da matricula e para o primeiro dia de aula. Caso necessário, também era providenciado reforço escolar para suprir as deficiências de aprendizado dos adolescentes.

Os egressos também recebiam auxílio na procura de emprego. Recebiam treinamento de habilidades sociais para as entrevistas ainda quando internados, depois eram acompanhados até as agências de emprego e eram ensinados a procurar vagas em anúncios de jornais. 
Os adolescentes egressos também eram auxiliados na procura, escolha e matricula em cursos técnicos de seu interesse. Através de informativos dos locais que ofereciam estes cursos, os adolescentes discutiam com a equipe seus interesses, habilidades, ofertas de empregos e conhecimentos prévios a respeito dos cursos, para assim decidir qual eles iriam cursar. Resolvido isto, eram acompanhados até o local do curso para a realização da matricula, e também no seu primeiro dia de aula, para facilitar o trajeto da sua moradia até a instituição e solucionar possíveis duvidas que pudessem aparecer.

Como a maioria dos egressos não possuía nenhuma documentação, com o auxilio dos acompanhantes era providenciado toda a documentação necessária. Desde as fotografias até o preenchimento das requisições e formulários, os adolescentes eram acompanhados e auxiliados para providenciar documentos de identidade, titulo de eleitor, certificado de reservista, CPF e histórico escolar. Além de providenciar os documentos, os adolescentes eram instruídos da importância dos mesmos e suas funções.

Depois de providenciado a documentação necessária os adolescentes eram acompanhados até uma agência bancária, para a abertura de uma conta, que possibilitava a eles receber dinheiro que eles haviam acumulado durante seu período de internamento e também para receber seus salários quando empregados. Era ressaltada a importância de guardar o dinheiro recebido assim como planejar seus orçamentos mensalmente.

Os egressos também eram auxiliados na compra de roupas e calçados adequados para sua nova realidade de estudo e trabalho, que incluía calças, camisas e sapatos. Também eram orientados de como se vestir para entrevistas e para o dia a dia de seus empregos. Além disso eram auxiliados na compra de artigos de higiene pessoal, 
como sabonete, xampu, condicionador, desodorante, pasta e escova dental; eram fornecidas instruções de uso e conservação dos mesmos.

Os adolescentes eram acompanhados até um supermercado para comprar alimentos e produtos necessário em seu dia a dia. Eram instruídos a pesquisar preços, avaliar o custo/beneficio dos produtos e também avaliar as reais necessidades de cada um, adequando seus gastos a seus orçamentos.

Como parte do programa a continuidade da terapia após sua desinternação era ofertada ao adolescente. Com o auxilio dos acompanhantes eles eram instruídos e acompanhados até o consultório particular de sua terapeuta, mostrando como chegar, seja de transporte publico coletivo ou a pé. Além disso eram instruídos a compartilhar com sua terapeuta as dificuldades encontradas nesta nova rotina, afim de proporcionar um melhor auxilio dos acompanhantes nas novas demandas encontradas.

\section{Psicoterapia Individual ${ }^{9}$}

Tinha como objetivo, em linhas gerais, proporcionar a criação de vínculo através da relação terapêutica e posteriormente reflexão dos atos infracionais, elaboração de planos para o futuro, entre outros. As sessões eram semanais e tinham com responsável uma psicoterapeuta voluntária, com formação em análise do comportamento.

\section{Psicoterapia Familiar}

Tinha como objetivo principal que os familiares compreendessem a função da família no desenvolvimento e manutenção do comportamento anti-social. Em apenas uma caso chegou a ocorrer, pois faz parte do perfil desta população a não adesão

\footnotetext{
${ }^{9}$ Este é o procedimento alvo de estudo neste trabalho, portanto nesta seção ele é brevemente descrito, nas linhas gerais de descrição de todo o programa do qual fazia parte.
} 
da família ao tratamento. Ocorreu nos moldes de uma psicoterapia formal com a mãe e irmãs de um dos adolescentes.

\section{Psicoterapia em Grupo}

Foram assim chamadas sessões que eram programadas para promover a reflexão sobre determinado assunto a partir da discussão do tema em grupo. Permitia ao psicoterapeuta avaliar os comportamentos dos clientes em interação com outros adolescentes, fornecendo material também para a discussão nas sessões individuais. 


\section{Problema e Objetivos de Pesquisa}

Verificar se intervenções terapêuticas analítico-comportamentais com adolescentes infratores de alto-risco produzem melhoras em demonstrações de afeto e expressões adequadas de desagrado, frustração e hostilidade, e diminuição de expressões inadequadas de raiva, hostilidade, culpar o outro e mentir, relatadas ou observadas durante sessões de psicoterapia. Identificar as intervenções mais utilizadas e verificar se as mudanças estão relacionadas à diminuição da reincidência criminal, permanência na escola, manutenção do trabalho, nível de interação satisfatório (menor número de interações coercitivas e maior número de interações de expressão adequada de emoções), e promoção de auto-sustento.

Objetivos:

Avaliar:

1- Aumento de comportamentos desejáveis

a. Expressão de sentimentos positivos

b. Expressão de arrependimento genuíno

c. Auto-revelação

2- Diminuição de comportamentos indesejáveis

a. Hostilidade

b. Mentira

c. Culpar o outro pelos próprios atos. 


\section{MÉTODO}

\section{Participantes}

Participaram deste estudo 11 adolescentes infratores internos da Unidade Fênix (unidade de internamento para adolescentes infratores de alto-risco do IASP-PR), que fizeram parte de um programa individualizado de tratamento para infratores de altorisco, pois cometeram delitos considerados graves. O tempo de internamento variou de poucos meses até no máximo três anos.

TABELA 1

Participantes do estudo

\begin{tabular}{|c|c|c|c|c|}
\hline Adolescente & Idade & Internamentos & $\begin{array}{l}\text { Passagens } \\
\text { em } \\
\text { delegacia }\end{array}$ & Delitos \\
\hline G.F. & $\begin{array}{l}19 \\
\text { anos }\end{array}$ & 2 & 2 & $\begin{array}{l}\text { Assalto/ Líder de gangue/ } \\
\text { Tráfico }\end{array}$ \\
\hline R. & $\begin{array}{l}18 \\
\text { anos }\end{array}$ & 1 & 0 & Assalto/ Seqüestro \\
\hline Mi. & $\begin{array}{l}17 \\
\text { anos }\end{array}$ & 3 & 4 & 2 Homicídios/ Assalto \\
\hline E. & $\begin{array}{l}18 \\
\text { anos }\end{array}$ & 1 & 8 & $\begin{array}{l}\text { Tráfico/ Tentativa de } \\
\text { homicídio/ Furto/ Atentado } \\
\text { violento ao pudor }\end{array}$ \\
\hline G. & $\begin{array}{l}18 \\
\text { anos }\end{array}$ & 7 & 19 & Assalto/ Homicídio \\
\hline A. & $\begin{array}{l}15 \\
\text { anos }\end{array}$ & 1 & 3 & $\begin{array}{l}\text { Homicídio / Tráfico/ } \\
\text { Receptação }\end{array}$ \\
\hline C. & $\begin{array}{l}16 \\
\text { anos }\end{array}$ & 1 & 2 & 2 Latrocínios/ Homicídio \\
\hline $\mathrm{Ce}$ & $\begin{array}{l}17 \\
\text { anos }\end{array}$ & 2 & 6 & Furto qualificado/ Homicídio \\
\hline M & $\begin{array}{l}17 \\
\text { anos }\end{array}$ & 1 & 0 & 2 Homicídios \\
\hline MM & $\begin{array}{l}14 \\
\text { anos }\end{array}$ & 3 & 5 & Homicídio \\
\hline $\mathrm{JC}$ & $\begin{array}{l}17 \\
\text { anos }\end{array}$ & 3 & 4 & $\begin{array}{l}\text { Tentativa de homicídio, } \\
\text { Homicídio }\end{array}$ \\
\hline
\end{tabular}

Até a presente data passaram pelo internamento no referido centro, 34 adolescentes. Destes 17 ainda se encontram internados.

As infrações, que apenas em dois dos casos eram episódios únicos (ambos cometeram parricídio), comumente são de múltipla ocorrência para cada adolescente, ou seja, 32 adolescentes cometeram mais de um delito em suas breves carreiras infracionais. 
$65 \%$ dos adolescentes cometeram homicídio, sendo que destes dois são parricidas e um latrocida. As tentativas de homicídios estavam presentes em $27 \%$ dos prontuários, sendo que as sucedem $18 \%$ de casos de roubo e $15 \%$ de autuações que incluem porte ilegal de armas de uso restrito. Furto está presente na história de $15 \%$ dos adolescentes, assim como o tráfico de entorpecentes, com a mesma porcentagem. Há 9\% de casos de atentado violento ao pudor e $6 \%$ de estupros. Em menor porcentagem, porém também de alta gravidade, se apresentam 3\% de casos de lesões corporais e $1 \%$ de seqüestro, receptação, formação de quadrilha e falsa identidade. Do número total seis foram considerados líderes da rebelião de setembro de 2004 no Educandário São Francisco, na qual sete jovens foram mortos.

Os adolescentes encontravam-se internados em regime fechado em um centro de socioeducação na cidade de Piraquara, Paraná. O centro é uma instituição do governo do estado do Paraná e recebe adolescentes do sexo masculino autores de ato infracional, de 14 a 18 anos, encaminhados mediante decisão judicial para cumprimento de medida sócio-educativa de internação, procedentes das diversas Comarcas do Estado do Paraná. O objetivo do centro de socioeducação é atender o adolescente autor de ato infracional, contribuindo para ações de caráter emancipador, promovendo sua mudança de forma crítica e reflexiva em busca da cidadania. Eram desenvolvidos nesta unidade programas específicos de Educação Escolar, Ensino Profissionalizante, Atendimento Técnico, Assistência Médico-Odontológica, Atividades Religiosas e Programa de Disciplina e Segurança.

Fisicamente, a Unidade consistia em dois prédios. Um com 17 alojamentos individuais, um banheiro com ducha para os adolescentes, uma sala de atividades, uma sala que funcionava como refeitório para os funcionários, um banheiro para os funcionários, uma cozinha e uma quadra para atividades físicas. O outro prédio possuía 
um espaço administrativo, uma recepção, uma copa, quatro banheiros, uma sala de medicações, uma sala de visitas, duas salas para o corpo técnico e pedagógico e quatro salas de atividades (utilizadas para aulas, atendimento psicvológico, cursos profissionalizantes, videoteca, grupos terapêuticos) . O espaço foi sendo gradativamente modificado e passando por reformas para melhor atender às necessidades do programa que lá havia. A equipe multidisciplinar era formada por médico psiquiatra (que visitava esporadicamente a unidade), psicóloga, assistente social, terapeuta ocupacional e pedagoga. Os educadores sociais eram os responsáveis pela segurança e trabalhavam em

turnos diurnos com grupos de três ou quatro e noturnos em duplas. A unidade possuía um programa próprio e suas atividades eram planejadas e supervisionadas por uma psicóloga especialista contratada pelo estado como assessora governamental para assuntos relacionados aos jovens infratores.

\section{Instrumentos}

\section{I - Diagnóstico: IEP e história familiar, Ficha de Recepção}

II- Acompanhamento na Unidade (instrumentos utilizados no dia a dia, avaliação de comportamento diária,quem ia para grupo de hs, comportamento moral, etc)

\section{III - Instrumentos Clínicos}

Foi utilizado (1) um instrumento para caracterização dos participantes (IEP); (2) uma medida de comportamentos inadequados realizadas diariamente por técnicos e educadores da unidade; (3) um instrumento baseado na observação clínica do terapeuta para avaliar mudanças comportamentais do cliente, e (4) um instrumento formado por categorias de comportamentos do terapeuta para conhecer as intervenções utilizadas nas sessões. Além destas, foram coletadas medidas comportamentais sobre a permanência na escola, manutenção do trabalho, nível de interação familiar, 
manutenção individual ou familiar em psicoterapia até a alta e promoção de autosustento, e conseqüentemente a não reincidência criminal.

1- Inventário de Estilos Parentais (IEP) (Gomide, 2006).

Objetivo: avaliar os estilos parentais. É um instrumento que possui três versões. Uma é aplicada nos pais, é chamada IEP auto-aplicação, ou seja, os próprios pais respondem sobre seus comportamentos. As outras duas formas quem responde é o filho (a partir de nove anos, aproximadamente); uma versão é sobre as práticas maternas e outra sobre as práticas paternas. Neste estudo foi utilizada a versão na qual o próprio adolescente responde. O Inventário é composto por 42 questões relativas às sete práticas parentais: monitoria positiva, comportamento moral, punição inconsistente, negligência, disciplina relaxada, monitoria negativa e abuso físico. As questões devem ser respondidas de acordo com uma escala: sempre, às vezes e nunca. A pontuação final total indica quatro tipos de estilos parentais: estilo parental ótimo; bom - acima da média; bom - abaixo da média e estilo parental de risco (Tabela 2).

TABELA 2

Interpretação dos resultados do IEP

\begin{tabular}{l|l}
\hline Percentuais do IEP & Interpretação do Resultado \\
\hline De 80 a 99 & Estilo parental ótimo, com presença marcante das práticas
\end{tabular}
parentais positivas e ausência das práticas negativas.

De 55 a 75

Estilo parental regular, acima da média, porém aconselha-se a leitura de livros de orientação para pais para aprimoramento das práticas parentais.

De 30 a 50

Estilo parental regular, porém abaixo da média. Aconselhase a participação em grupos de treinamento de pais.

De 1 a 25

Estilo parental de risco. Aconselha-se a participação em programas de intervenção terapêutica, em grupo, de casal ou individualmente, especialmente desenvolvidos para pais com dificuldades em práticas educativas nas quais possam ser enfocadas as conseqüências do uso de práticas negativas em detrimento das positivas. 
É possível realizar a análise individual de cada um dos estilos parentais citados (Tabela 2) e indicar o tipo de procedimento clínico que deverá ser utilizado com a família, orientação, treinamento e intervenção.

Tabela 3. Dados normativos Indicativos de Risco de acordo com cada prática educativa.

\begin{tabular}{l|l|l}
\hline Práticas Educativas & Materna & Paterna \\
\hline Monitoria Positiva & $\mathrm{N} \leq 8$ & $\mathrm{~N} \leq 7$ \\
Comportamento Moral & $\mathrm{N} \leq 7$ & $\mathrm{~N} \leq 6$ \\
Punição Inconsistente & $\mathrm{N} \geq 5$ & $\mathrm{~N} \geq 5$ \\
Negligência & $\mathrm{N} \geq 3$ & $\mathrm{~N} \geq 4$ \\
Disciplina Relaxada & $\mathrm{N} \geq 4$ & $\mathrm{~N} \geq 4$ \\
Monitoria Negativa & $\mathrm{N} \geq 7$ & $\mathrm{~N} \geq 6$ \\
Abuso Físico & $\mathrm{N} \geq 1$ & $\mathrm{~N} \geq 2$ \\
\hline
\end{tabular}

2- Avaliação comportamental diária

Foram construídas duas planilhas mensais, uma de comportamentos adequados e outra de inadequados, para cada adolescente. Todos os dias os educadores e técnicos (cada um destes possuía um número de identificação) deveriam anotar seu número na coluna do comportamento observado de cada adolescente. Efetivamente foi utilizada apenas a de comportamentos inadequados, já que a de comportamentos adequados não era preenchida com a mesma freqüência.

Os comportamentos inadequados observados da lista são:

1. Xingou o educador

2. Esmurrou/ chutou porta

3. Recusou-se a fazer atividade

4. Recusou-se a voltar para cela

5. Foi devolvido para a cela por mau comportamento

6. Pegou objetos sem autorização

7. Brigou

8. Ameaçou alguém com objetos

9. Ameaçou com palavras 


\section{Reclamou excessivamente}

11. Quebrou coisas ou objetos

12. Deixou de fazer alguma refeição

13. Estava com "estoque ${ }^{10 ", ~}$

14. Recusou-se a fechar a portinhola

3- Sistema de Avaliação de Comportamentos-alvo do Cliente - SACC (Yano \& Meyer, 2003, Yano, 2003)

É um instrumento que se baseia na observação clínica do terapeuta, explicitando os critérios utilizados e que pode ser aplicado de forma contínua para analisar tendências dos comportamentos. Categorias de comportamento são criadas com base em relatos verbais do cliente e o terapeuta pontua os comportamentos em uma escala de 0 a 2.

Com base na literatura sobre adolescentes anti-sociais foram construídos dois grupos de comportamentos para análise, um de comportamentos indesejáveis, ou anti-sociais, que são o alvo da modificação de comportamento (no sentido de redução ou de eliminação de tais comportamentos), e outro de comportamentos desejáveis ou pró-sociais que são as metas da psicoterapia, buscando elevar ou introduzir no repertório dos clientes tais condutas. No grupo de comportamentos indesejáveis estão a hostilidade, a mentira e atribuição de culpa pelos atos aos outros. Os comportamentos desejáveis ou pró-sociais são objetivos da ressocialização por serem incompatíveis com os comportamentos ligados à reincidência criminal. São eles: auto-revelação, expressões de arrependimento (culpa e vergonha), e expressão de sentimentos positivos.

\footnotetext{
${ }^{10}$ Estoque é qualquer objeto perfurante, feito a partir de plástico, metal, madeira, vidro, usado como arma, faca, pelos adolescentes. Exemplo comum são cabos de escova de dentes que lixados se transformam em objetos cortantes como facas.
} 
No trabalho psicoterápico com adolescentes infratores é possível observar padrões de comportamento descritos claramente pela literatura e que diferem dos padrões comportamentais da população não anti-social. Os comportamentos mais emblemáticos desta população são: a hostilidade, a mentira, atribuição de culpa ao outro, a falta de vergonha, falta de autocrítica e a falta de expressão adequada de sentimentos e a dificuldade de estabelecer vínculos.

Com base nesta literatura podem ser construídos dois grupos de comportamentos para futuras análises: um de comportamentos indesejáveis, ou antisociais, que são o alvo da modificação de comportamento, e outro de comportamentos desejáveis ou pró-sociais que são as metas da psicoterapia. No grupo de comportamentos indesejáveis estão a hostilidade, a mentira e atribuição de culpa pelos atos aos outros.

Ainda no grupo de comportamentos desejáveis deve ser incluído um subgrupo de comportamentos sociais dos mais complexos, segundo Del Prette e Del Prette (2001), a expressão de sentimentos positivos.

Neste trabalho optou-se por apresentar uma operacionalização dos comportamentos do psicoterapeuta com base nas práticas parentais relacionadas ao desenvolvimento ou inibição do comportamento anti-social de Gomide (2006).

Em cada categoria foi utilizado um sistema de pontuação, variando de zero a dois pontos (pior avaliação $=0$ a melhor avaliação $=2$ nos comportamentos desejáveis, e melhor avaliação ou não ocorrência $=0$ a pior avaliação ou ocorrência $=2$ nos comportamentos indesejáveis, respectivamente). Esse sistema de pontuação tem por objetivo permitir comparações entre categorias e participantes. 


\section{Comportamentos indesejáveis}

\section{Hostilidade}

2 Se expressa com hostilidade: Cliente relata ou terapeuta observa que não se expressou assertivamente frente ao outro demonstrando hostilidade. Cliente relatou ações agressivas contra patrimônio ou pessoas na unidade ou fora dela. A hostilidade envolve sentimentos de raiva, descontentamento e agressividade em vários níveis.

1 Incipiente ou Expressou-se com dificuldade: Cliente relata ou terapeuta observa que o cliente percebeu que seria hostil em se expressar, porém não deixou de fazê-lo ou que se expressou com hostilidade, mas ficou preocupado como o efeito de seu comportamento sobre o outro. Se contradiz, relata de forma amena e também agressiva para o mesmo ato.

o Expressou-se sem hostilidade: Cliente relata ou terapeuta observa que o cliente se expressou (não verbalizou apenas) sem hostilidade (avaliada pelo tom de voz, postura relaxada e olhar "relaxado") mesmo em assuntos que discordava, não se sentia bem ou não queria falar.

\section{Mentira}

2 Várias: Observou-se ou cliente relatou três ou mais comportamentos de inventar fatos, ou omiti-los na semana, ou durante a sessão de psicoterapia. Diante dos fatos conhecidos o cliente nega, inventa.

1 Poucos: Observou-se ou cliente relatou que apresentou até dois comportamentos de inventar fatos, ou omiti-los na semana (ou durante a sessão) ou não chegou a apresentar o comportamento, mas relatou situações passadas ou possíveis ocorrências 
de conduta anti-social que envolviam mentiras. Ex.: "Eu falei pra professora que tava com dor de cabeça, por isso que não fiz nada." Discriminar mentira branca da prejudicial.

0 Nenhum: Observou-se ou cliente relatou que não apresentou comportamentos de mentir, inventar ou omitir e nem os relatou em sessão. Ex.: "Eu fiz como você sugeriu. Falei que não fiz porque não entendi porra nenhuma”. Assumir responsabilidade pelos erros e déficits. Falar a verdade sobre fatos que antes omitia ou mentia sobre.

\section{Culpar o outro}

2 Muitas atribuições de culpa e reclamações: Relatos ou observações de que culpou outros, apresentou queixas das pessoas na sessão (ex. não se sente compreendido pelo outro, não recebeu ajuda ou apoio porque o outro não fez, sente-se discriminado pelas atitudes dos outros). Estas reclamações devem estar relacionadas a comportamentos dos outros que supodtamente interferem no comportamento do adolescente. Ex.1: Referindo-se ao abuso cometido contra um adolescente que possuía um severo retardo mental, tendo comportamentos de uma criança de seis anos: "Foi isso mesmo. Pior pra ele que é retardado. Ele que quer jogar com nós. Daí ele apostou o ânus com o F. e comigo um oral. Ela sabia o que estava fazendo. Perdeu tem que pagar". Diz que a vítima mereceu ser roubada, "deu mole”, estava na rua escura, ou era cagueta, mereceu morrer. Ex.2: “Aquela professora é muito mole, daí eu não tenho vontade de estudar porque ela muito ruim de dar a matéria."

1 Poucas atribuições de culpa aos outros e reclamações: Relatos ou observações de melhorias no relacionamento, mudanças no seu comportamento assim como no comportamento dos outros, com poucas atribuições de culpa aos outros e 
reclamações acerca dos outros (ex. responsabiliza-se mais pelos acontecimentos, reconhece sua participação nas situações, dá menor importância ao que o outro diz, é ouvido com menos críticas, sente-se mais compreendido). Ex.: "Eu errei tudo lá na hora de preencher a ficha na agência. Eu tava nervoso e deu um branco. Daí eu pensei que devia ter estudado nessa vida mesmo. Mas vô falar, a lazarenta da mulher nem pra me ajudar a desgraçada! Ela piorou a situação, ficou me apressando e nem ofereceu ajuda. Também não pedi, mas ela tinha que ter oferecido! É o trabalho dela!" Ainda há ausência de autocrítica.

O Sem atribuições de culpa aos outros e reclamações: Responsabilização pelos próprios atos. Relatos ou observações de que se responsabilizou por atitudes em situações de relacionamento, mudou na relação com os outros, não apresentou queixas e nem culpou ninguém por seus problemas (ex. responsabilizou-se pelas próprias dificuldades, faz e recebe elogios, refere ter bom relacionamento, sente-se mais compreendido, recebeu ajuda, conversou mais). Ex.: "Eu não vim porque gastei o dinheiro de vir com lanche e fiquei sem jeito de pedir emprestado. Eu não sei cuidar de dinheiro. Sempre veio fácil, ia fácil. Agora preciso aprender a me controlar, mas é muito difícil”.

\section{Comportamentos Desejáveis}

\section{Auto-revelação}

0 Nenhuma: não fez relatos sobre si mesmo e nem revelou infrações ou atitudes moralmente reprováveis que possa ter cometido ao longo de sua vida, abusos sofridos ou perpetrados. 
1 Alguma revelação: quando questionado fez relatos sobre si mesmo e nem revelou infrações ou atitudes moralmente reprováveis que possa ter cometido ao longo de sua vida, bem como abusos sofridos ou perpetrados. Ex.: “Ah... eu usava um pouco, só nos finais de semana, mas era pouco, nunca fui viciado."

2 Revelação espontânea: fez relatos sobre si mesmo e revelou sem questionamento imediato, infrações ou atitudes moralmente reprováveis que possa ter cometido ao longo de sua vida, bem como abusos sofridos ou perpetrados. Ex.: "Esta noite tive sonhos medonhos de novo. Acho que eu preciso falar uma coisa... Sabe aquela treta lá da delegacia... pois é... eu fiz sexo com o maluco mesmo. Mas não foi como disseram. Foi $\operatorname{assim}(\ldots) . "$

\section{Expressão de arrependimento}

0 Nenhum: não fez relatos característicos de arrependimento, tampouco apresentou expressões verbais ou gestuais indicativas de culpa, vergonha ou empatia.

1 Algum arrependimento: fez relatos pouco característicos de arrependimento, ou apresentou expressões verbais ou gestuais empobrecidas ou confusas indicando sentimento de culpa, vergonha ou empatia. Ex.: Com a cabeça baixa, olha intermitentemente na direção do psicoterapeuta, esfrega as mãos, leva a mão à boca enquanto diz: "É...talvez eu não devia ter feito... hoje pensando eu não sinto bem, mas na hora pá! Ou é ou não é, daí já viu. Mas não dá nada, vamo fala de outras parada vai."

2 Arrependimento: fez relatos característicos de arrependimento, apresentou expressões verbais ou gestuais congruentes e indicativas de culpa, vergonha ou empatia. Ex.: Com a cabeça baixa, não olha na direção do psicoterapeuta, cobre a 
face com as mãos e com a voz embargada diz: "Eu podia ter parado tudo aquilo, eu podia ter dito pare, eu não falei nada pra não matarem... Eu fui muito ruim, o filho do demônio mesmo".

\section{Expressão de sentimento positivo}

O Não consegue se expressar: Não expressou sentimentos de afeto indicadores de apego e vínculo em situações narradas e nem durante a psicoterapia.

1 Incipiente ou Expressou-se com dificuldade: O cliente diz ter pensado em expressar sentimentos de afeto indicadores de apego e vínculo, porém não teve coragem ou expressou-se, mas ainda ficou preocupado com a reação do outro. Ex.: "Você viaja bastante hein, os piá aí reclamaram de ficar sem terapia”.

2: Expressou-se sem dificuldade: Relato ou observação de expressão de sentimentos de afeto indicadores de apego e vínculo. Ex.: "É muito ruim ficar sem terapia porque não tenho ninguém como você para conversar. Você é gente fina, eu gosto muito".

4- Instrumento para avaliação de comportamentos do terapeuta: sistema de categorias de registro das verbalizações do terapeuta adaptado do sistema desenvolvido por Zamignani e Meyer (2007, em elaboração) como parte da tese de doutorado do primeiro autor.

Objetivo: caracterização e análise de comportamentos na interação terapeutacliente. Para tanto são utilizados critérios de categorização das sessões gravadas em áudio ou vídeo a fim de normatizar o processo e evitar diferenças entre observadores devido a escolhas divergentes relativas a esse processo. Os observadores recebem uma lista de categorias com os devidos critérios e a cada fala do terapeuta escutada na fita de 
áudio devem fazer a categorização utilizando as siglas correspondentes. Em cada uma destas categorias estão presentes a definição, a forma, o contexto (precedente e subseqüente) e critérios de inclusão ou exclusão, com seus respectivos exemplos. São as categorias para análise do comportamento do terapeuta: 
TABELA 4

Sistema de categorias de registro das verbalizações do terapeuta (Zamignani e Meyer, 2007, em elaboração)

\begin{tabular}{|c|c|}
\hline \multicolumn{2}{|c|}{ CATEGORIAS DO TERAPEUTA } \\
\hline \multirow[t]{2}{*}{ 1. Terapeuta solicita relato - SRE (Relato) } & 1.1. SRE: Solicitação de informações sobre eventos \\
\hline & $\begin{array}{l}\text { 1.2. SRE: Solicitação de relatos de sentimentos ou relato de } \\
\text { eventos relacionados a sentimentos }\end{array}$ \\
\hline 2. Terapeuta facilita o relato do cliente - FAC (Facilitação) & 2.1. FAC: verbalizações mínimas \\
\hline \multirow[t]{7}{*}{ 3. Terapeuta demonstra empatia - EMP (Empatia) } & 3.1. EMP: nomeação de sentimentos \\
\hline & 3.2. EMP: exclamações empáticas \\
\hline & 3.4. EMP: validação de discordância ou críticas do cliente \\
\hline & 3.5. EMP: humor \\
\hline & 3.6. EMP: apoio \\
\hline & 3.7. EMP: comentários de entendimento \\
\hline & 3.8. EMP: paráfrases \\
\hline \multirow[t]{5}{*}{ 4. Terapeuta fornece informações - INF (Informação) } & 4.1. INFO: Informações factuais \\
\hline & 4.6. INFO: Qualificação de eventos \\
\hline & 4.7. INF: Justificativas de intervenções \\
\hline & 4.8. INFO: Descrição do programa terapêutico \\
\hline & 4.9. INFO: Contrato terapêutico \\
\hline \multirow[t]{4}{*}{ 5. Solicitação de reflexão (SRF) } & 5.1. SRF: Solicitação de reflexão \\
\hline & 5.2. SRF: Solicitação de explicação ou interpretação \\
\hline & 5.3. SRF: Solicitação de avaliação \\
\hline & 5.4. SRF: Solicitação de previsão \\
\hline \multirow{4}{*}{$\begin{array}{l}\text { 6. Terapeuta recomenda ou solicita a execução de ações, } \\
\text { tarefas ou técnicas - REC (Recomendação) }\end{array}$} & 6.1. REC: Conselhos \\
\hline & 6.2. REC: Modelo \\
\hline & 6.3. REC: Incentivo \\
\hline & 6.4. REC: Estruturação de atividade \\
\hline \multirow{8}{*}{ 7. Terapeuta interpreta - INT (Interpretação) } & 7.4. INT: Diagnóstico \\
\hline & 7.5. INT: Devolutiva de avaliação padronizada \\
\hline & 7.6. INT: Estabelecimento de síntese \\
\hline & 7.7. INT: Metáforas ou analogias explicativas \\
\hline & 7.8. INT: Inferências \\
\hline & 7.9. INT: Previsões \\
\hline & 7.10. INT: Confrontação \\
\hline & 7.11. INT: Normalização \\
\hline \multirow{9}{*}{$\begin{array}{l}\text { 8. Terapeuta aprova ou concorda com ações ou avaliação do } \\
\text { cliente - APR (Aprovação) }\end{array}$} & 8.1. APR: Avaliação positiva sobre o cliente \\
\hline & 8.2. APR: Elogios \\
\hline & 8.3. APR: Descrição de ganhos terapêuticos \\
\hline & 8.4. APR: Verbalizações de concordâncias \\
\hline & 8.5. APR: Pseudo-discordância \\
\hline & 8.6. APR: Relato de sentimentos positivos \\
\hline & 8.7. APR: Exclamações de aprovação \\
\hline & 8.8. APR: Sorrisos de aprovação \\
\hline & 8.9. APR: Agradecimentos \\
\hline \multirow{6}{*}{$\begin{array}{l}\text { 9. Terapeuta reprova ou discorda com ações ou avaliação do } \\
\text { cliente - REP (Reprovação) }\end{array}$} & 9.1. REP: Discordância \\
\hline & 9.2. REP: Crítica \\
\hline & 9.3. REP: Ironia \\
\hline & 9.4. REP: Ameaça \\
\hline & 9.5. REP: Paráfrase crítica \\
\hline & 9.6. REP: Auto-revelações desafiadoras \\
\hline
\end{tabular}




\section{Procedimento}

Para que esta pesquisa iniciasse foi solicitada autorização à direção da instituição responsável pelos adolescentes. Os participantes, selecionados em um centro de socioeducação específico para adolescentes de alto risco, primeiramente foram esclarecidos sobre os procedimentos da pesquisa e da intervenção. Quando concordavam em participar o responsável legal durante sua internação, ou seja, o diretor da unidade onde estava internado assinava o Termo de Consentimento Livre e Esclarecido (Anexo 4). Inicialmente, os adolescentes e quando possível seus pais eram solicitados a responder o IEP para que a pesquisadora pudesse se certificar de que se encontravam na faixa de classificação de Estilos Parentais de Risco, pois era de interesse da mesma que os adolescentes atendidos viessem de famílias com práticas educativas negativas. O IEP era aplicado em qualquer espaço autorizado pela equipe de segurança onde pudesse ser colocada uma mesa e duas cadeiras. A pesquisadora procedia à aplicação explicando o que era o questionário, qual o objetivo, e lia as questões uma a uma, explicando-as em linguagem acessível e dando exemplos plausíveis para aquela população ${ }^{11}$. O adolescente podia questionar caso não compreendesse e respondia oralmente. Caso fornecesse dados adicionais, estes eram registrados em uma folha à parte. A aplicação deste instrumento, se não fosse realizada antes do inicio da psicoterapia, deveria ser realizada durante a sessão tão logo quanto fosse possível. Foi feita a designação aleatória dos participantes para a ordem de início do atendimento, pois existiam no começo quatro adolescentes disponíveis para atendimento, solicitando-se para a equipe de segurança que fosse trazido um dos quatro. Dava-se início à intervenção psicoterápica com o adolescente na própria unidade, enquanto que as sessões com familiares também podiam ser agendadas no consultório

\footnotetext{
${ }^{11}$ Uma versão adaptada do instrumento para adolescentes infratores está em desenvolvimento.
} 
da terapeuta. A psicoterapia foi conduzida pela pesquisadora, que tem formação e prática profissional psicoterápica há 10 anos em análise do comportamento. A profissional é mestre em psicologia da infância e da adolescência e cursa doutorado em psicologia clínica. As sessões foram dirigidas com base nos princípios behavioristas, considerando os principais instrumentos para condução das mesmas a análise funcional do comportamento dos participantes e a relação terapêutica. As sessões com o grupo familiar, quando ocorreram, seguiram os mesmos moldes da análise do comportamento, tal como as sessões individuais. Quando chegava na unidade a pesquisadora primeiramente segundo orientações de segurança lia o livro de ocorrências, dando especial atenção aos fatos que envolviam seus clientes. Dados desta leitura não eram discutidos em sessão com os adolescentes. Em seguida verificava as fichas de Avaliação Comportamental Diárias (Anexo 6) dos clientes. Todos os dias os educadores e técnicos anotavam seu número na coluna do comportamento inadequado observado de cada adolescente. Estes comportamentos tinham conseqüências em termos de sanções disciplinares e através deste registro a psicoterapeuta sabia em que condições trabalharia naquele dia, quem poderia atender no tempo adequado, quem estava de medida disciplinar e o que havia feito. Os adolescentes sabiam dos procedimentos que envolviam a liberação ou não da atividade de psicoterapia, pois havia sido explicitado no contrato de terapia. As sessões dos quatro primeiros participantes aconteceram na instituição em locais improvisados (ex.: corredor de passagem adaptado com mesa e cadeiras para atendimento, sala de aula com grades na porta e sem janela, pátio externo de atividade, em baixo de uma escada-caracol num espaço destinado a uma futura lavanderia, dentro de um veículo kombi estacionado dentro do pátio da unidade). A partir do quinto cliente-participante outras salas foram disponibilizadas, uma na própria unidade e outra em um educandário a quatro quilômetros dali, para o qual era feito o 
transporte da terapeuta e do adolescente (que fazia o percurso algemado nos punhos e nos tornozelos), em um veiculo do tipo kombi, acompanhados por seguranças. No final do oitavo mês das atividades da pesquisadora, o espaço físico destinado a atividades escolares, médicas e psicológicas, entre outras, ficou pronto. Desta forma algumas sessões puderam ser realizadas em local adequado, arejado, iluminado, com silêncio, privacidade e segurança. No início das primeiras sessões a psicoterapeuta mostrava o gravador, lembrando ao adolescente do procedimento. Ela então pedia ao agente de segurança que retirasse as algemas do adolescente, desde que o mesmo não estivesse cumprindo medida disciplinar por descumprimento de normas da unidade. Quando o adolescente estava cumprindo uma medida disciplinar, além de ter que permanecer algemado, a sessão era mais curta que o habitual e o tema era direcionado para análise da situação/ comportamento que teve como conseqüência a medida disciplinar. As normas disciplinares determinavam a suspensão de todas as atividades com exceção da psicoterapia. Usualmente, no término das sessões o adolescente permanecia sentado e a psicóloga autorizava a entrada dos agentes de segurança para condução do adolescente de volta para o alojamento ou para outras atividades. Quando outros instrumentos de medida em forma de inventários eram utilizados, isto ocorria como recurso dentro da própria sessão de psicoterapia, foi o caso da aplicação do IHS (Inventário de Habilidades Sociais) em alguns adolescentes. A psicoterapeuta apresentava o instrumento, explicava os objetivos e lia as questões para o adolescente, explicando e exemplificando sempre que necessário. Na medida em que alguns participantes foram desinternados, foi feito o recontrato, através do qual o adolescente e sua família puderam optar pela continuidade da psicoterapia como parte do Programa de Egressos implementado pelo grupo de pesquisa sobre comportamentos anti-sociais do qual esta pesquisadora também faz parte. A psicoterapia do egresso, e de seu grupo familiar 
quando possível, era realizada no consultório da terapeuta, sem custos para o mesmo e seguindo os mesmos procedimentos de registro das sessões utilizados enquanto o adolescente estava internado. A continuidade da psicoterapia foi oferecida a todos os adolescentes que a iniciaram na unidade e foram desinternados.

Para proceder à análise dos dados obtidos algumas categorias de comportamentos dos participantes foram formuladas. Algumas delas foram criadas a partir da literatura na área de adolescentes infratores e outras a partir do registro das sessões quando um tema era recorrente para o cliente. Tais categorias, apesar de encontrarem respaldo na literatura existente, podem ser consideradas subjetivas, por isso houve esforço a fim de tornar as descrições operacionais e assim, serem passíveis de replicação e haver concordância entre observadores.

As sessões de psicoterapia foram gravadas em áudio e analisadas, os conteúdos foram agrupados por temas considerados (a) comportamentos indesejáveis, ou anti-sociais e (b) comportamentos desejáveis, ou pró-sociais. Foi utilizado um sistema de pontuação, variando de zero a dois pontos (pior avaliação $=0 \mathrm{a}$ melhor avaliação $=2$ nos comportamentos desejáveis, e melhor avaliação ou não ocorrência $=0$ a pior avaliação ou ocorrência $=2$ nos comportamentos indesejáveis, respectivamente).

Os comportamentos indesejáveis avaliados relacionam-se à expressão de repertório anti-social do adolescente e foram: a hostilidade, a mentira e a atribuição de culpa. Os comportamentos desejáveis relacionam-se aos pró-sociais e foram: autorevelação, expressão de arrependimento e expressão de sentimento positivo. 
No caso modelo utilizado neste trabalho foi aplicado o IEP e no decorrer das sessões o IHS. A análise dos comportamentos do cliente nas sessões de foi realizada pela pesquisadora utilizando o Sistema de Avaliação de Comportamentos-alvo (SACC) do Cliente com as categorias de comportamentos desejáveis e indesejáveis criadas para o estudo. As sessões terapêuticas foram analisadas para os comportamentos do cliente em função de categorias que permitem analisar as variações de demonstração de afeto e expressão adequada de desagrado e frustração dos clientes, com a finalidade de observar se houve aumento e melhoria da qualidade dos comportamentos de demonstração de afeto e expressão adequada de desagrado e frustração, bem como de diminuição da expressão inadequada de sentimentos ligados à raiva e a frustração. Os comportamentos do psicoterapeuta foram analisados de acordo com o sistema de classificação de Zamignani(2007), mas há também a possibilidade se analisar os comportamentos de acordo com as práticas educativas empregadas pelo terapeuta.

No primeiro caso analisado (S11) a pesquisadora escutou as sessões gravadas em áudio e pontuou os comportamentos do cliente de acordo com o SACC. Os comportamentos do terapeuta foram levantados por estagiários voluntários de psicologia treinados para utilizar o sistema de categorias de registro das verbalizações do terapeuta adaptado do sistema desenvolvido por Zamignani (2007). Os voluntários, após receber treino, recebiam uma fita de áudio com a sessão para ser analisada. Eles tiveram em média quatro horas para realizar a análise de cada fita de áudio. Os dados obtidos foram analisados e comparados pela pesquisadora, que optou por associar a esta apresentação uma descrição breve das sessões e do contexto na qual ocorreram, relacionando alguns dados com acontecimentos que não poderiam ser inferidos apenas a partir das análises quantitativas realizadas. Também foram considerados e alguns dos casos os dados relativos às avaliações comportamentais diárias e as variáveis: permanência na escola, 
manutenção do trabalho, promoção de auto-sustento e consequentemente, a reincidência criminal.

A partir da discussão ${ }^{12}$ do caso 11 foram determinados os critérios para análise dos demais casos.

${ }^{12}$ Em banca de qualificação, para a qual se destinava a confecção deste trabalho. 


\section{RESULTADOS E DISCUSSÃO}

Para proceder à análise de dados das sessões de psicoterapia foram selecionados quatro alunos do último ano do curso de psicologia de uma faculdade particular da cidade de Curitiba que tinham interesse em participar voluntariamente como juizes de pesquisa. Optou-se por alunos que realizavam a formação clínica em análise do comportamento.

Quatro sessões de treinamento, com duração aproximada de quatro horas, foram realizadas. Nestas ocasiões os alunos receberam instruções sobre como utilizar o Sistema de Avaliação de Comportamentos-alvo do Cliente - SACC (Yano \& Meyer, 2003, Yano, 2003) e o Instrumento para avaliação de comportamentos do terapeuta: sistema de categorias de registro das verbalizações do terapeuta adaptado do Sistema Multidimensional de categorização de comportamentos da relação terapêutica de Zamignani (2007).

Depois que lhes eram explicados os instrumentos, de posse da cópia de cada um deles, os alunos recebiam também uma sessão de psicoterapia transcrita para avaliar na presença da pesquisadora. Desta forma, assim que as dúvidas apareciam eram sanadas pela pesquisadora. $\mathrm{Na}$ etapa seguinte os alunos levavam uma cópia de uma transcrição para fazer em casa. Esta cópia deveria ser entregue assim que completada, possibilitando que a pesquisadora a corrigisse para estabelecer a prontidão do juiz. Quando o aluno atingisse um índice de concordância de no mínimo $70 \%$ ele passava a receber sessões gravadas para analisar. A pesquisadora fazia um controle da qualidade do trabalho escolhendo trechos de sessões para conferir e indagando os alunos sempre que algum resultado parecia fora do padrão geral (por exemplo, números muito elevados ou baixos de determinado comportamento). 
Depois de conferir as análises, a pesquisadora passava os dados para planilhas nos programas Excel e SPSS.

Como o número de sessões era substancial optou-se por escolher algumas sessões do início, do meio e do fim do processo, sendo que aqueles casos que tiveram processos mais longos de psicoterapia deveriam ter mais sessões analisadas. Um fator de exclusão de sessões foi a qualidade de algumas gravações que impossibilitava a compreensão de grandes trechos.

Individualmente os casos foram analisados através do programa SPSS. Utilizou-se o teste de correlação de Spearman para identificar possíveis relações entre os comportamentos do terapeuta e os comportamentos do cliente.

Os dados de todas as sessões analisadas foram conjuntamente analisados através do teste de Correlação de Spearman, a fim de identificar padrões consistentes de relacionamento das variáveis dentre todos os processos.

\section{ANÁLISE GERAL DO PROCESSO}

Foram analisados os dados de 11 clientes num total de 99 clientes da mesma psicoterapeuta.

Quanto aos comportamentos da terapeuta (Figura 1) verificou-se através das médias de ocorrências por sessão de psicoterapia que ao longo de todos os processos o comportamento mais presente nas sessões foi o de solicitar relato (SRE) com média de 40 ocorrências por sessões e o que menos apareceu teve média de três ocorrências por sessão e é o comportamento de reprovação (REP). 


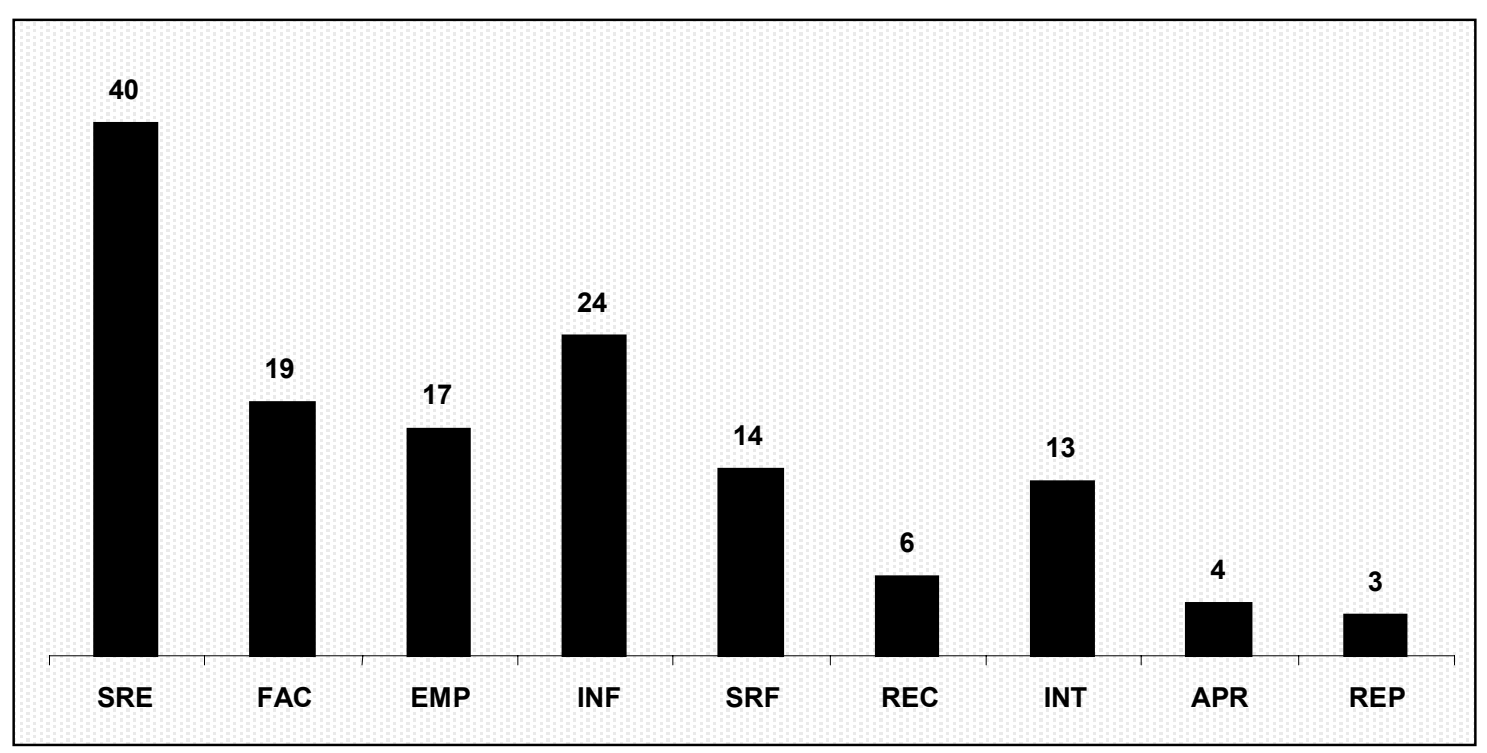

Figura 1. Média geral dos comportamentos do terapeuta.

Utilizando o teste não-paramétrico de Spearman foram encontradas correlações significativas entre alguns comportamentos do terapeuta e do cliente nas sessões de psicoterapia dos 11 clientes:

- Solicitação de relato do terapeuta e mentira do cliente $(\rho=.249)$

- Solicitação de relato do terapeuta e culpar do cliente $(\rho=.284)$

- Facilitação do terapeuta e culpar do cliente $(\rho=.295)$

- Recomendação do terapeuta e culpar do cliente $(\rho=239)$

- Informação do terapeuta e expressão de sentimento positivo do cliente ( $\rho=$ $.206)$

- Solicitação de reflexão do terapeuta e culpar do cliente $(\rho=.254)$

- Solicitação de reflexão do terapeuta e expressão de sentimento positivo do cliente $(\rho=-.224)$

- Reprovação do terapeuta e culpar do cliente $(\rho=.232)$

- Reprovação do terapeuta e expressão de sentimento positivo do cliente ( $\rho$ = $.347)$ 
É preciso retomar algumas características típicas da população atendida para que se construa uma discussão. Infratores possuem repertório do comportamento de mentir altamente desenvolvido, o que equivale dizer que mesmo que estejam conversando em situação não-terapêutica este comportamento terá uma alta taxa de ocorrência. Portanto, quando se obtém o dado de que há uma correlação positiva entre a solicitação de relato do terapeuta e a mentira (.250) e o culpar do cliente (.288) confirma-se estes padrões comportamentais.

Culpar terceiros e mentira do cliente estão correlacionados com vários comportamentos do terapeuta, o que pode indicar sua força, independentemente do comportamento do terapeuta.

A categoria de análise do comportamento do terapeuta de "Solicitação de relato" (Zamignani, 2007) compreende as verbalizações nas quais ele solicita ao cliente descrições de eventos, sentimentos ou pensamentos; pode também acontecer quando ao cliente é solicitado que registre informações. Os relatos solicitados incluíam ações do cliente bem como de outras pessoas, relatos de sentimentos e pensamentos, perguntas de como o cliente agiu ou agiria em determinadas situações, questões sobre história de vida do cliente e situações relacionadas com o comportamento infrator. Nas sessões iniciais, onde havia maior ocorrência de solicitação de relato pelo terapeuta, era também onde ainda não se tinha construído vínculo. Com a existência de uma fraca aliança terapêutica, somada à importância de se obter dados nesta fase do processo e ainda ao comportamento típico do infrator (de mentir e culpar os outros pelos próprios atos), a correlação da solicitação de relato com mentira e com culpar outros faz sentido.

A categoria de comportamento do terapeuta "Solicitação de Reflexão" compreende verbalizações nas quais ele solicita ao cliente qualificações, explicações, interpretações, reflexões ou previsões a respeito de qualquer tipo de evento. Estes 
eventos ou situações podem ser sobre comportamentos do cliente ou de outras pessoas, sentimentos, pensamentos ou tendências de ação do cliente, aspectos da história de vida e situações relacionadas ou não ao comportamento do cliente (Zamignani, 2007). Ressaltando esta última parte da definição da categoria "situações relacionadas ou não ao comportamento do cliente" é possível apontar que provavelmente nas sessões iniciais o cliente principalmente respondesse a este tipo de comportamento do terapeuta relatando situações relacionadas a outras pessoas, responsabilizando-as pelos atos que na verdade eram de sua alçada. Este é um dos exemplos claros do comportamento de culpar o outro, típico dos infratores e um dos alvos de modificação em psicoterapia.

Outra importante correlação encontrada que deve ser discutida é entre os comportamentos de reprovação do terapeuta, culpar e expressão de sentimento positivo do cliente. A categoria Reprovação é descrita por Zamignani (2007) como composta por verbalizações do terapeuta que sugerem um julgamento desfavorável a diferentes tipos de ações ou verbalizações do cliente, tais como discordar, criticar, ironizar, ameaçar, parafrasear criticamente, auto-revelar-se de forma desafiadora, relatar sentimentos negativos e advertir.

Cabe frisar aqui que se no processo psicoterápico de populações nãoinfratoras este tipo de comportamento do terapeuta pode criar um ambiente altamente desfavorável para a construção da aliança terapêutica por tornar este ambiente aversivo, no processo junto a infratores este tipo de comportamento é imprescindível para demonstrar a consistência e genuinidade dos comportamentos do terapeuta. $\mathrm{Na}$ realidade parece que este tipo de comportamento não torna o ambiente da psicoterapia aversivo para os infratores, tendo em vista que o ambiente em que estes jovens cresceram era altamente coercitivo e violento. 
Partindo das definições operacionais de Zamignani (2007) para os tipos de reprovação é possível compreender a relação destes comportamentos do terapeuta com os comportamentos do cliente.

"Discordância: Verbalizações nas quais o terapeuta discorda ou expressa julgamento desfavorável sobre ações, avaliações afirmações propostas ou características do cliente, sejam estas relatadas pelo cliente ou observadas pelo terapeuta."

Quando o terapeuta discordava contingentemente a comportamentos que os próprios adolescentes sabiam ser inadequados (ex.: chutar a porta) de acordo com as regras da unidade, por exemplo, o comportamento do terapeuta provavelmente era percebido pelos jovens como a prática educativa de monitoria positiva. Ou seja: a partir de regras claras o comportamento do adolescente é consequenciado de forma contingente. Logo, quando o adolescente culpava outros pelos próprios atos o terapeuta apontava os comportamentos e dava as conseqüências previamente combinadas, como, por exemplo, mudar o assunto em questão, ou até mesmo encerrar o atendimento.

"Crítica: Verbalizações nas quais o terapeuta descreve falhas do cliente ou critica suas ações, características ou aparência."

Também com o comportamento de crítica pode-se justificar que dentro de uma perspectiva de proporcionar modelo e ampliar repertório não infrator $\mathrm{o}$ psicoterapeuta o fizesse com a finalidade principal de descrever o comportamento inadequado para que em seguida fosse possível discutir comportamentos mais adequados para dada situação. Por exemplo, quando os jovens diziam que não estudavam porque as professoras eram ruins, a terapeuta dizia que eles não precisavam responsabilizar os outros, pois isso não resolveria o problema de não estudar. Que este era um comportamento que naquele caso poderia ser substituído por uma conversa franca na qual os adolescentes ao invés de culpar as professoras por não ensinarem, 
solicitariam às mesmas que explicassem novamente, ou de outra maneira àquilo que não tinham entendido. Pode-se supor então que este comportamento de reprovação através de crítica fosse seguido por fornecer modelo e propor resolução de problemas.

"Ironia: Comentários de qualquer natureza feitos em tom sarcástico ou hostil com relação ao cliente. Comentários do terapeuta que sugerem incredulidade a respeito de relatos do cliente sobre o que disse ou fez ou terapeuta ri de algo que o cliente disse ou fez."

Já o comportamento de ironizar deve ser evitado no manejo com infratores, pois dele pode-se inferir a desvalorização dos comportamentos do outro, este sim um comportamento bastante aversivo para infratores, e porque não dizer para qualquer cliente em psicoterapia.

Faz-se necessário considerar o comportamento de ameaçar tal como descrito nesta categoria e através de um dos exemplos fornecido pelos autores:

"Ameaça: Verbalizações nas quais o terapeuta prevê conseqüências negativas ou aversivas para uma ação (ou pela não ação) do cliente em forma de ameaça. (...) Ex: $>$ T: Você pode escolher fazer isto deste modo ou ser miserável o resto de sua vida. [REP]"

Este tipo de comportamento do terapeuta durante o processo de psicoterapia dos adolescentes infratores objetivava descrever contingência e estabelecer relação entre os comportamentos dos adolescentes e as possíveis conseqüências. A terapeuta diria ao cliente, por exemplo, "Você está recebendo uma oportunidade para ter uma profissão e poder sair do crime, se você fugir estará demonstrando que na verdade não estava comprometido com a mudança e estará escolhendo viver como um criminoso." Contudo, apesar de encaixar-se na descrição de "Ameaça” não parece que a função deste comportamento seja de ameaçar, mas sim de descrever as conseqüências de um comportamento. 
Especialmente quando os clientes culpavam outros pelos atos que tinham cometido, o comportamento de reprovação através da Paráfrase Crítica se fazia presente.

"Paráfrase crítica: Paráfrase de verbalização anterior do cliente que explicita uma crítica ou aponta uma falta ou erro do cliente."

A seguinte passagem ocorreu entre a terapeuta e S1 na ocasião de uma "greve" que os adolescentes tentaram realizar e retrata o uso da paráfrase crítica relacionada com o culpar o outro.

S1: Esses educador pilantra fica tirando os piá. Os piá não fez nada. Nóis não faz nada e eles fica tirando nóis.

T: Então a culpa de você não vir para terapia foi dos educadores?

S1: É uai... Pior... Não, não é que seje culpa deles... ehhhh... assim né... Eles treta com os irmão, daí nóis escolhe o lado dos irmão de caminhada. Os irmão falaram que ninguém ia sair pra atividade, então eu não sai ara, eu não ia ser pilantra de forga com os irmão.

T: Entendi. Os irmãos, que não têm terapia, têm um problema com os educadores e exigem que você, que não tem problemas com os educadores, deixe de vir para a sua atividade. E você obedece os irmãos de crime... Entendi. E você está entendendo?

"Auto-revelações desafiadoras: Verbalizações nas quais o terapeuta relata sua experiência com relação a um evento do qual o cliente se queixa, sugerindo que sua atuação foi melhor que a do cliente ou que, se ele conseguiu solucionar o problema, o cliente também deveria conseguir."

As auto-revelações desafiadoras foram utilizadas pela psicoterapeuta quando já se avaliava a existência de vínculo com os adolescentes, pressupondo que dar exemplos da própria vida não seria desqualificado por parte dos jovens. Em situações nas quais os clientes justificavam comportamentos inadequados ou a não realização de atividades culpando outras pessoas e sendo hostis, fazia-se necessário que a terapeuta interviesse de forma incisiva, deixando claro para o cliente que a responsabilidade pelos próprios comportamentos, bem como a persistência, eram importantes comportamentos a serem aprendidos. 
"Relato de sentimentos negativos: Relato de sentimentos que o cliente desperta no terapeuta que indicam que não gosta dele ou de algo que ele faça ou que não está sentindo-se bem com algum aspecto relativo ao comportamento do cliente."

Já na próxima subcategoria, relatos de sentimentos negativos do terapeuta, podem ser compreendidos os comportamentos do terapeuta que tinham como objetivo sensibilizar o cliente para os sentimentos do outro, desenvolvendo assim sua empatia. Obviamente que este tipo de intervenção somente possui validade se há vínculo formado entre terapeuta e cliente. Além disso, relatar para o cliente como estava se sentindo também tinha a função de dar modelo e explicitar o que estava desencadeando determinados comportamentos, como por exemplo, encerrar o atendimento por ter sido ofendida e ficado magoada.

Muito se fez uso dos comportamentos de advertência conforme descrito a seguir:

"Advertência: Verbalizações nas quais o terapeuta diz ao cliente que ele está impedindo o progresso terapêutico ou o andamento da sessão."

O contexto no qual isso ocorria geralmente visava apontar para o cliente como as mentiras, a hostilidade e o culpar os outros dificultavam o andamento das sessões e a evolução do processo psicoterápico.

Da mesma forma que os comportamentos descritos acima se relacionam positivamente na análise estatística, sugerindo a existência da co-ocorrência entre eles, é preciso então apontar a relação negativa entre os comportamentos do terapeuta na categoria de reprovação e a expressão de sentimento positivo do cliente, também ressaltada pelo teste estatístico. Ou seja, fica claro que quando o terapeuta reprova não há por parte do cliente apresentação de expressão de sentimentos positivos, e vice-versa, o que pode ser explicado pela incompatibilidade da ocorrência de comportamentos 
inadequados (dentre os quais temos a mentira, hostilidade e culpar) e comportamentos adequados (entre os quais, a expressão de sentimentos positivos). Então, se o que se espera do infrator é que ao longo de sua psicoterapia aprenda a expressar sentimentos positivos, não havia por que reprovar o aparecimento deste comportamento.

Para aprofundar a discussão serão apresentadas as análises individuais de cada caso, destacando as semelhanças e diferenças encontradas nos processos.

Com objetivo de esclarecer e facilitar a leitura dos resultados de cada participante será apresentado um resumo do histórico de vida de cada um deles. Desta maneira, a análise e discussão possivelmente ficarão mais claras.

\section{S1: O BONZINHO}

Filho mais novo de uma família com nove filhos S1 descrevia a si mesmo como o queridinho da mamãe, sendo que as irmãs mais velhas também ajudaram a criá-lo. A mãe sempre foi dona de casa e o pai agricultor sempre nutriu apreço por armas. Apesar de S1 relatar que os pais possuíam práticas educativas adequadas (Tabela 5), o relato das irmãs dizia que ele teve uma educação permissiva, que fazia o que queria, na hora que queria e tudo o que fazia era aprovado e festejado. Quando seus pais eram solicitados a se manifestar sobre o histórico infracional do filho, o pai omitia-se e a mãe chorava. Porém nenhum dos dois repreendia S1. A primeira vez que S1 usou drogas foi para fazer parte turma de um dos irmãos, que não o aceitou no grupo mesmo assim. Desta forma ele fez novas amizades e como era respeitado por ser irmão de X, ele obteve crédito com o traficante. Passou então a revender drogas para os amigos e em poucos meses já tinha seu ponto de vendas; isso com pouco mais de 10 anos. Das drogas para as armas e para os acertos de contas foi uma passagem muito rápida. Aos 12 anos $\mathrm{S} 1$ participou de um homicídio, aos 14 recebeu a medida 
socioeducativa de internamento por duplo homicídio. Dono de grandes olhos azuis, S1 facilmente cativava amigos e profissionais. Foi dos adolescentes mais resistentes à aliança terapêutica, tendo um comportamento de mentir aprimoradíssimo e praticamente nenhuma hostilidade expressa. Quando foi desinternado participou de um programa de primeiro emprego do governo do estado e morou em um quarto alugado de uma casa de família. Enquanto aguardava uma vaga na escola devido ao período do ano, S1 foi visitar a família em um feriado e não retornou. Tentou na cidade natal matricular-se em duas escolas e foi recusado. Mais de uma vez foi abordado por policiais que queriam saber como andavam suas atividades criminais; apesar dele afirmar que estava fora do tráfico, os policiais não acreditavam. Arrumou uma namorada e certa noite ao brigar com a mesma foi para uma festa e cheirou cocaína. Relatou ter tido a pior paranóia de sua vida, sentindo que o colega que estava com ele iria puxar a arma e matá-lo a qualquer momento. Depois deste dia nunca mais usou o entorpecente. Aproximadamente depois de seis meses em liberdade, fazendo bicos, S1 foi preso por receptação de toca-cds roubado. Ao reencontrar a psicoterapeuta não negou; contou que havia cedido seu ponto de drogas para um colega e que tinha que tirar um troco, pois a namorada estava grávida. Afirmou que não voltara a traficar e achava ser incapaz de voltar a matar uma pessoa.

O participante 1 (S1) passou por 22 sessões de psicoterapia, das quais nove foram analisadas. O processo teve inicio no mês de maio de 2005 .

$$
\text { Solicitado a escrever uma redação intitulada "Meus Amigos" o }
$$
adolescente escreve um texto que demonstra claramente seu comprometimento infracional. Esta redação foi escrita no mês de abril de 2005 em uma atividade escolar e segue na íntegra, inclusive com erros gramaticais e gírias. 


Meus amigos
Eu tenho varios amigos, tanto na rua e na cadeia
Gosto muito deles, porque amigo de verdade não
deixa você falando, meus amigos de rua são muito
legais, tem um que se chama [X], ele
mora perto da minha casa, nois ia junto para
a escola, eu e ele estudava na mesma sala,
eu treinava futebol e ele treinava também,
poriço nois sempre andava junto, os meus outros
amigos eu andava junto bastante ia em
altos festeiros junto com eles, era
muito gostoso porque só tinha amigo na
festa, não tinha briga nas festa, era raro
alguém se desentender, mais
logo pregava a paz de novo todo o
ano nois ia para a esposicão curti
um pouco, é craro que todos os meus
amigos era que nem eu gostava de
beber um pouco de cerveja, ums
ficava muito loco, e tinha que leva
ele embora, mais era de mil.
Meus amigos da cadeia são gente fina eles
são lado a lado comigo na caminhada
e bom ter amigo na cadeia porque você
não fica sozinho tem um parceiro
para segui junto com você, não importa
o crime que eles cometeu, crime por crime
eu também fiz, importa a pessoa deles
como eles são com você, poriço eu sou
lado a lado com eles e eles é lado a lado
com migo.
FIM

A Figura 2 abaixo mostra na distribuição linear das sessões, quais as analisadas.

\begin{tabular}{|l|l|l|l|l|l|l|l|l|l|l|l|l|l|l|l|l|l|l|l|l|l|l|}
\hline Sessões & 1 & 2 & 3 & 4 & 5 & 6 & 7 & 8 & 9 & 10 & 11 & 12 & 13 & 14 & 15 & 16 & 17 & 18 & 19 & 20 & 21 & 22 \\
\hline Analisadas & \multicolumn{1}{|c|}{} & & & & & & & & & & & & & & & & & & & \\
\hline
\end{tabular}

Figura 2. Sessões de psicoterapia analisadas do participante S1.

A Figura 3 apresenta as médias dos comportamentos inadequados e adequados do cliente S1 ao longo das sessões analisadas. Importante destacar algumas informações quanto às sessões em questão, tal como a sessão 6 (dia 17 de junho de 
2005) na qual pela primeira vez não ocorrem comportamentos inadequados. Nesta sessão o cliente foi confrontado por ter aderido a uma manifestação negativa na instituição, o que ia contra algumas coisas que ele havia relatado anteriormente em terapia. Porém a terapeuta o faz sinalizando compreender a necessidade de se manter fiel aos colegas naquele contexto, mesmo quando sabe que está errado. Já na sessão 8 (dia 27 de julho) há um aumento expressivo de comportamentos inadequados e nenhuma emissão de comportamentos desejáveis, pois o tema discutido foi $o$ comportamento de mentir do cliente, que confirmou ter ainda envolvimento com o crime, mesmo estando preso. Na sessão 10 (dia 5 de setembro) o cliente demonstrou vários comportamentos de afeto, pois havia recebido um rato albino para tratar como animal de estimação. Falaram sobre a visita do irmão e pai, sobre os delitos cometidos e sobre os outros meninos da unidade. S1 contou as histórias de tentativas de homicídio e sobre as possibilidades de sair da facção criminosa. Falou também sobre como estava sempre junto com outros jovens delinqüentes para matar pessoas seguindo as determinações da "lei" do crime.

Na oitava sessão analisada (n¹5 - dia 8 de novembro de 2005) já não há mais ocorrências de comportamentos inadequados, o cliente encontrava-se em processo de atividades externas, convivendo com pessoas fora da unidade de internamento e relatava apreciar este fato. 


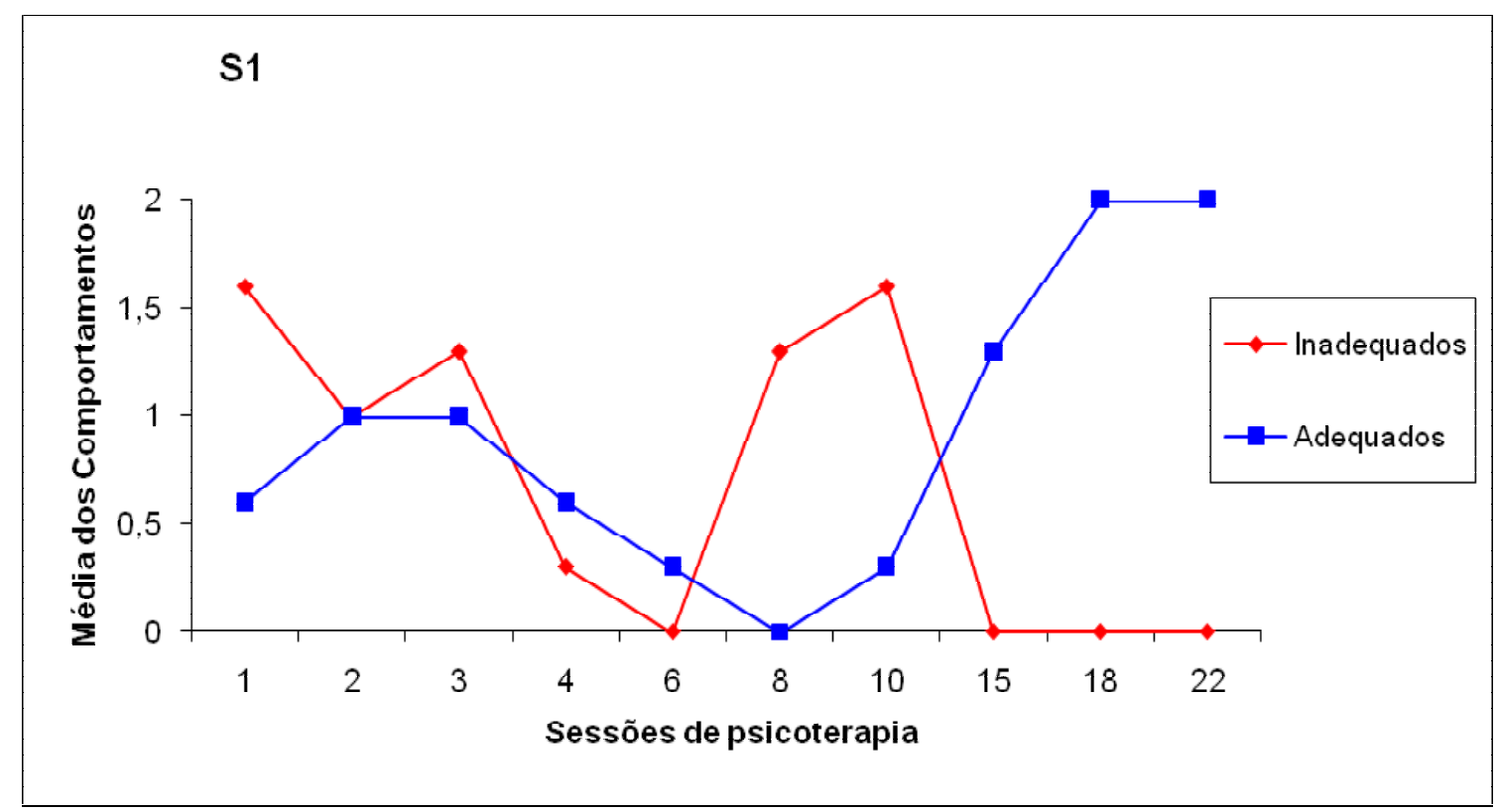

Figura 3. Média dos Comportamentos Inadequados e Adequados de S1 ao longo das sessões.

Ainda na Figura 3 observa-se a aparente presença de comportamentos adequados (pois S1 representava-os) até a oitava sessão, quando foi "desmacarado". Ao mesmo tempo na oitava sessão há ocorrência de comportamentos inadequados, que passam a inexistir a partir da $15^{\mathrm{a}}$ sessão, quando se atinge a pontuação ideal de comportamentos inadequados.

Na Figura 4 é possível observar através das médias dos comportamentos do terapeuta por sessão que a maior média é de solicitação de relatos (SRE).

As menores médias, indicando a menor ocorrência ao longo do processo de S1., são respectivamente as de reprovação (REP), aprovação (APR) e recomendação (REC) do terapeuta. 


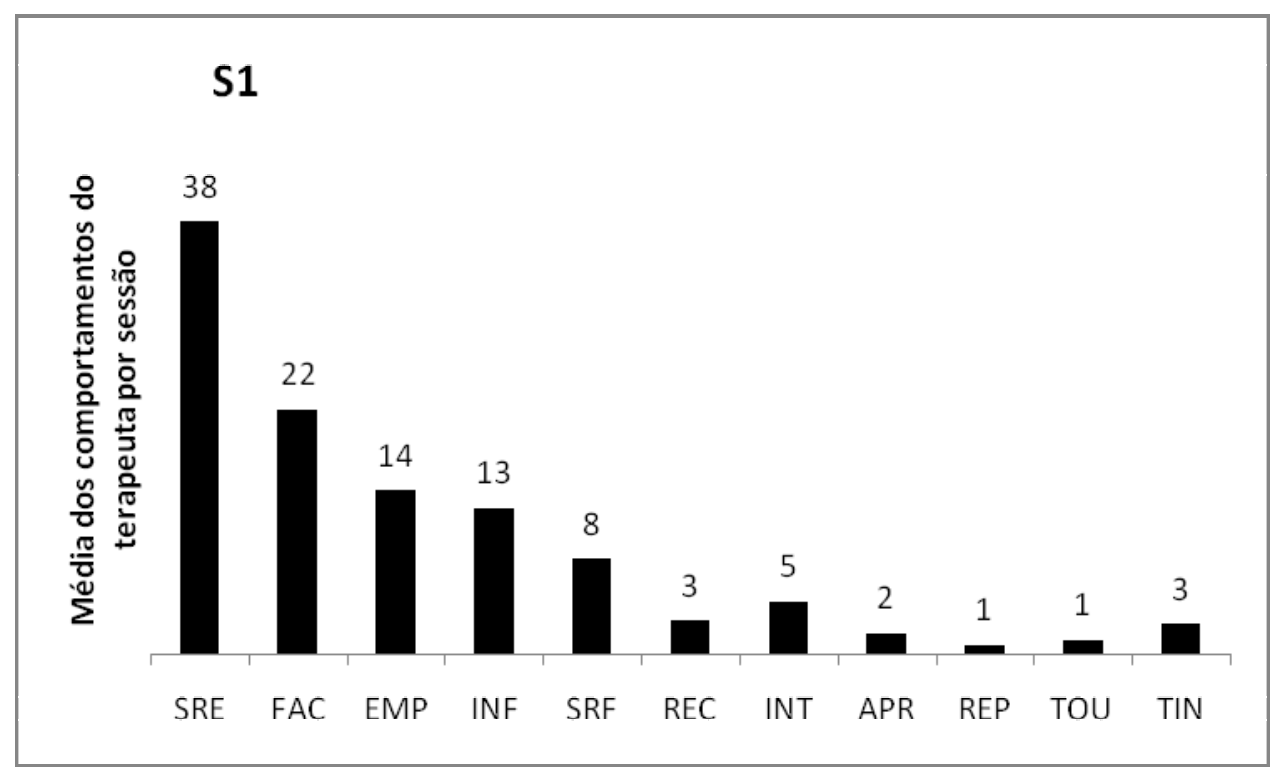

Figura 4. Média dos comportamentos do terapeuta por sessão no caso S1.

Utilizando o teste não-paramétrico de Spearman foram encontradas correlações positivas entre alguns comportamentos do terapeuta e do cliente nas sessões de psicoterapia:

- Facilitação do terapeuta e Hostilidade do Cliente $(\rho=.646)$

- Facilitação do terapeuta e Culpar do Cliente $(\rho=.704)$

- Recomendação do Terapeuta e Expressão de Sentimento Positivo do cliente ( $\rho=$ $.834)$

- Recomendação do Terapeuta e Expressão de Arrependimento do Cliente $(\rho=$ $.744)$

A categoria de comportamentos de Facilitação do terapeuta é definida por Zamignani (2007) como aquela que compreende vocalizações que indicam que ele está atento ao relato do cliente e sugerem a continuidade da fala do cliente. É constituída por verbalizações mínimas definidas por expressões vocais curtas que sugerem que o terapeuta está prestando atenção e que o cliente deve ou pode continuar falando. Sendo assim, de acordo com a análise estatística a ocorrência destes comportamentos do 
terapeuta relaciona-se positivamente a dois comportamentos inadequados do cliente $\mathrm{S} 1$ : hostilidade e culpar o outro.

Para discutir este dado é importante citar algumas características comportamentais de S1. Este cliente fez inúmeros esforços para ocultar da psicoterapeuta seus comportamentos anti-sociais. Mostrava-se pouco hostil, relatava poucos comportamentos hostis e mentia com tal convicção que se não fosse o ambiente controlado no qual se encontravam seria difícil detectá-las. Desta forma, sempre que surgia algum comportamento indicativo de hostilidade e de culpar o outro a psicoterapeuta procurava facilitar o aparecimento dos mesmos a fim de ter acesso aos comportamentos que de fato faziam parte do repertório infrator de S1. Além disso, facilitar a ocorrência destes comportamentos no início do processo pode ter contribuído para a construção de vínculo com este adolescente, que se sentia acolhido mesmo quando se comportava de forma hostil e culpando os outros. Importante ressaltar que a terapeuta não aprovava estes comportamentos, apenas não os punia e nem os colocava em extinção.

Com o cliente S1 também foram encontradas correlações positivas entre o comportamento do terapeuta de recomendação e comportamentos adequados do adolescente. Segundo Zamignani (2007) a categoria Recomendação agrupa verbalizações do terapeuta nas quais sugere alternativas de ação ao cliente ou solicita o engajamento do cliente em ações ou tarefas, podendo ocorrer na forma de conselhos, modelo, incentivo, estruturação de atividade e solicitação de parada.

O que torna tal relação observável no contexto terapêutico com infratores é que sem a formação de vínculo não é possível utilizar nenhum tipo de recomendação durante o processo. Ora, se esta categoria correlacionou-se com comportamentos adequados, que se espera, tenham sido desenvolvidos ao longo da psicoterapia, parece 
aceitável que tal correlação de fato exista. Sendo assim pode-se supor que a partir da avaliação da terapeuta de que se formava a aliança terapêutica, pois o jovem apresentava já alguns comportamentos adequados, neste caso de expressão de sentimento positivo e expressão de arrependimento, que a mesma fazia maior uso de recomendações.

Tabela 5. Práticas educativas dos cuidadores de S1 avaliadas através do Inventário de Estilos Parentais

\begin{tabular}{|c|c|c|c|c|c|c|c|c|}
\hline S1 IEP & 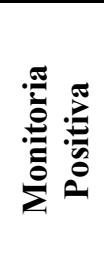 & 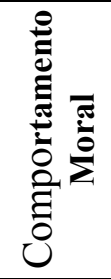 & 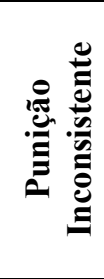 & 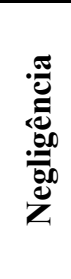 & 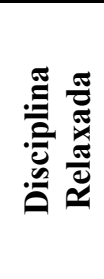 & 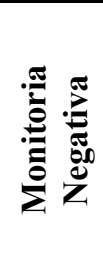 & 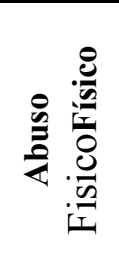 & IEP \\
\hline IEP Materno & 10 & 12 & 1 & 2 & 1 & 7 & 1 & +10 \\
\hline IEP Paterno & 8 & 10 & 4 & 2 & 0 & 7 & 4 & +1 \\
\hline
\end{tabular}

Analisando as práticas educativas dos pais de S1 tendo como referência os valores da Tabela 5 é possível perceber que a mãe possuía melhores práticas positivas do que o pai, contudo ambos utilizam práticas educativas negativas de monitoria negativa e de abuso físico. O índice total do IEP materno e do paterno indicavam Estilo Parental Regular, porém abaixo da média.

Sabe-se que os principais efeitos da utilização da monitoria negativa são comportamentos aprimorados de mentir e enganar, o que se observava claramente no repertório de $\mathrm{S} 1($ monitoria negativa materna e paterna $=7$ ). Outro possível efeito desta prática educativa é a construção de uma frágil auto-imagem e auto-estima, o que pode estar na base da associação a grupos desviantes conforma mostram alguns modelos de desenvolvimento de comportamento anti-social (ex.: Patterson et al., 1992).

O abuso físico está sabidamente relacionado ao desenvolvimento de comportamentos de risco que podem contribuir para o desenvolvimento de comportamento anti-social (abuso físico materno $=1$; abuso físico paterno $=4$ ). Além 
disso, crianças que são punidas fisicamente não aprendem os comportamentos alternativos àqueles que foram punidos, mas aprendem sim estratégias de esquiva do agente da punição.

\section{S2: O PROTEGIDO}

S2 nasceu em uma família ligada ao crime, não sabe dizer quando se envolveu diretamente, mas ele mesmo afirma que "deve ter sido desde sempre". Da relação conturbada de seus pais nasceram três meninos, de outros relacionamentos a mãe teve mais dois e adotou uma moça anos mais tarde. $\mathrm{O}$ pai teve mais dois filhos em outro casamento. O irmão mais velho de S2, com pouco mais de dezoito anos, foi assassinado no final do ano de 2006. A mãe nunca participou diretamente do tráfico ou de roubos, mas sua casa servia como esconderijo e depósito para mercadorias contrabandeadas e drogas. S2 não consegue lembrar-se do ofício do pai, mas a mãe relata que o pai estava ligado ao contrabando na fronteira, inclusive utilizando seus filhos, pequenos na época, para tal. S2 lembrava-se remotamente de situações com o pai que envolviam sexo e festas. A mãe confirmou que o pai levou S2 a prostíbulos quando ele tinha no máximo três ou quatro anos. Aos cinco S2 chorava muito e pedia para não ficar junto com o pai, que já estava separado da mãe. Como a mãe passava por dificuldades financeiras não atendeu aos pedidos do filho, que ficou mais de um ano com o pai, morando dentro de um carro em várias cidades do país. Iniciou o uso de entorpecentes aproximadamente aos onze anos e desta forma aproximou-se do crime, achando muito fácil roubar para comprar drogas, ir a festas e comprar roupas, tênis, etc. Quando tinha treze anos cometeu um crime bastante divulgado pela mídia nacional; durante um assalto em uma cidade turística, matou um senhor que era um turista internacional. Contou que se sentiu como uma celebridade. Recebeu a medida 
socieducativa de internamento e foi internado em uma unidade de sua cidade. Porém esteve envolvido em várias situações de conflito, o que culminou com a transferência de S2 para outra unidade do interior do estado. Foi quando o adolescente cometeu um homicídio, matando outro jovem do mesmo alojamento. Mais tarde soube-se que S2 perdera várias apostas no alojamento e passou a pagá-las com favores sexuais. Quando matou o outro adolescente esperava ser respeitado pelos demais. Devido a este episódio é que veio para a unidade onde era realizado o trabalho com esta pesquisadora.

O participante $2(\mathrm{~S} 2)$ passou por 22 sessões de psicoterapia, das quais 10 foram analisadas. A psicoterapia teve inicio no mês de março de 2005.

A Figura 5 abaixo mostra na distribuição linear das sessões, quais as analisadas.

\begin{tabular}{|l|l|l|l|l|l|l|l|l|l|l|l|l|l|l|l|l|l|l|l|l|l|l|}
\hline Sessões & 1 & 2 & 3 & 4 & 5 & 6 & 7 & 8 & 9 & 10 & 11 & 12 & 13 & 14 & 15 & 16 & 17 & 18 & 19 & 20 & 21 & 22 \\
\hline Analisadas & & & & & & & & & & & & & & & & & & & & & \\
\hline
\end{tabular}

Figura 5. Sessões de psicoterapia analisadas do participante S2.

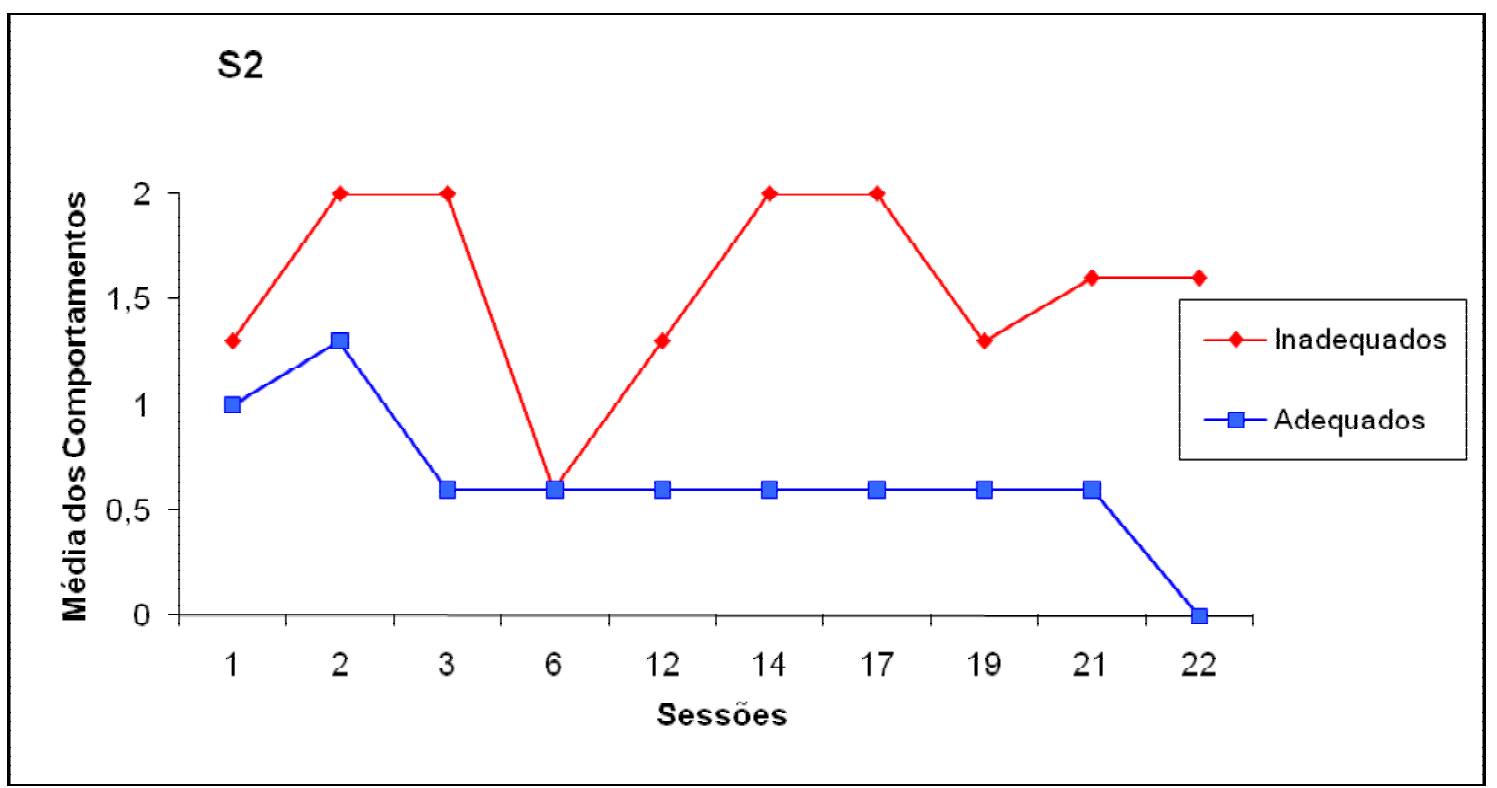

Figura 6. Média dos Comportamentos Inadequados e Adequados de S2 ao longo das sessões. 
A sessão de número 14 (Figura 6) foi a primeira sessão após o início do curso profissionalizante que S2 começou a fazer fora da unidade. Pode-se notar na mesma figura que há um aumento de comportamentos inadequados (Figura 6), mais tarde explicado pelo fato de que o adolescente usou a oportunidade do curso para levar drogas para dentro da unidade, sob ameaça de outro adolescente. Na décima sétima sessão, a psicoterapeuta confrontou S2 sobre a questão da droga e reprovou o comportamento do adolescente, que reagiu com acentuada agressividade e justificou seu comportamento alegando ter medo do rapaz que solicitava a droga. As últimas duas sessões analisadas ocorreram quando S2 encontrava-se já desinternado e estava em uma casa de semi-liberdade. A queda acentuada de comportamento adequados na última sessão analisada (Figura 6) deveu-se ao relato de uma briga com outros adolescentes da casa, na qual S2 esteve envolvido. Apenas após o desligamento do mesmo da psicoterapia e da ocorrência de novos atos infracionais é que se pôde determinar que o adolescente é possivelmente portador de distúrbio de personalidade anti-social (F 60.2) (DSM-IV-TR, 2002) com características psicopáticas (Hare, 1991). Em maio de 2008 este adolescente encontrava-se novamente preso por suposto latrocínio, que segundo técnicos forenses parece ter sido na verdade um crime encomendado de "queima de arquivo". 


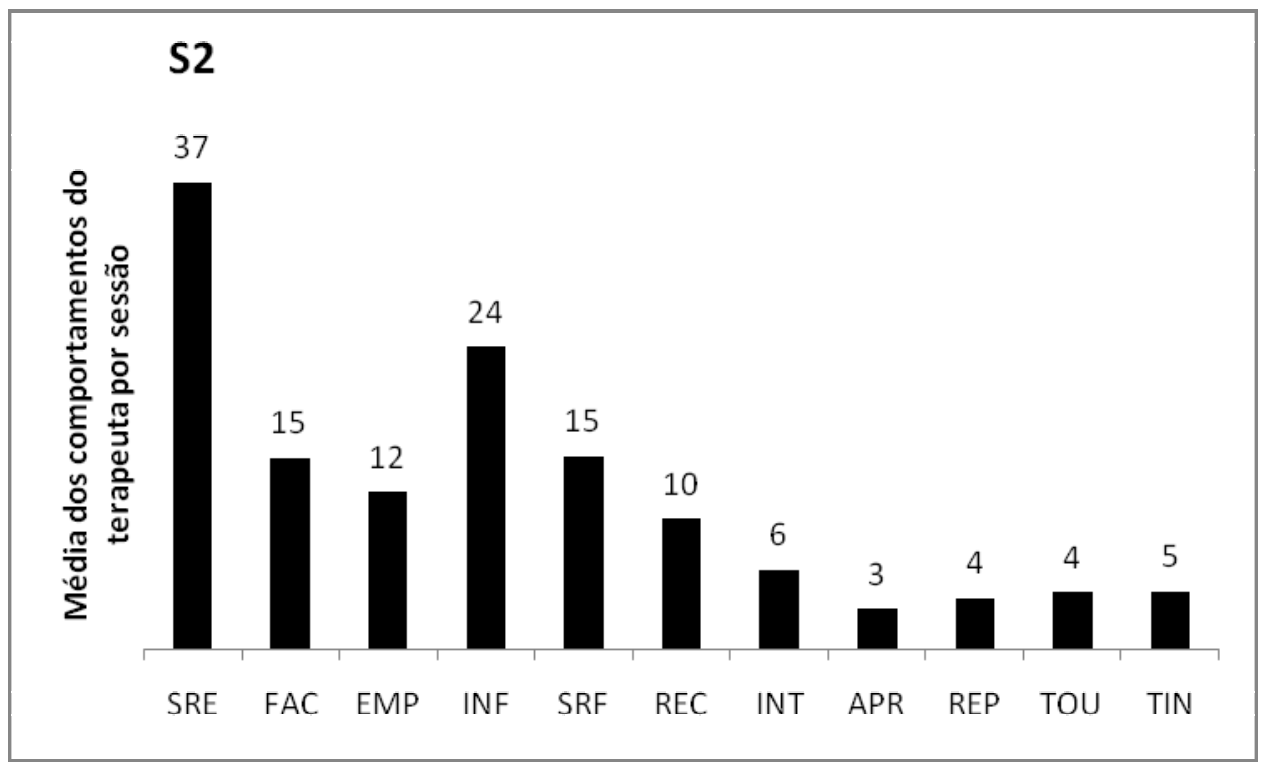

Figura 7. Média dos Comportamentos do Terapeuta por Sessão no Caso S2

A elevada média de comportamentos de informação do terapeuta (Figura 7), se comparada às médias dos demais comportamentos do terapeuta com este cliente, merece uma análise particular. S2 foi um dos clientes que mais exigiu atenção e demandou preocupação da psicoterapeuta, ao passo que também parecia ser um dos que mais sólido vínculo havia desenvolvido com a mesma. Como em outros casos, as médias mais baixas de comportamento do terapeuta são as de reprovação e aprovação.

O adolescente demonstrava insegurança excessiva, e que a princípio foi associada ao pobre repertório de resolução de problemas do jovem. Então, quando o jovem demonstrava excesso de ansiedade e descontrole emocional a psicoterapeuta procurava fomentar o autocontrole de S2 dando-lhe informações das mais diversas.

De acordo com a categoria de comportamentos do terapeuta, "Fornecer Informação" descrita por Zamignani (2007) estas são as verbalizações nas quais o terapeuta relata eventos ou informa o cliente sobre eventos, que não o comportamento do cliente ou de terceiros, estabelecendo ou não relações causais ou explicativas entre eles. Fazem parte desta categoria: (1) fornecer informações factuais (dados ou fatos relacionados a determinado assunto em discussão); (2) explicação de eventos (descrição 
de relações explicativas ou causais entre eventos - relações do tipo "se... então", quando estas não contém uma análise, descrição ou síntese do comportamento do cliente ou de terceiros); (3) explicação de contigüidade entre eventos (descrição na qual se explica a ocorrência de eventos em termos de relações de contigüidade - relações temporais entre eventos - relações do tipo "o evento $\mathrm{X}$ ocorre quando $\mathrm{Y}$ ocorre...", quando as mesmas não dizem respeito ao comportamento do cliente ou de terceiros); (4) descrição de padrões recorrentes de eventos; (5) explicações teóricas e experimentais de eventos; (6) qualificação de eventos; (7) justificativas de intervenções do terapeuta; (8) descrição do programa terapêutico e (9) contrato terapêutico.

Porém, depois do término do processo com este adolescente e com a reincidência (que será exposta e discutida mais adiante), percebeu-se que a função da suposta insegurança do jovem era desviar atenção da psicoterapeuta de outros comportamentos de S2. Então, quando ela apresentava este tipo de comportamento de fornecer informações, ela acabava por reforçar o comportamento infrator do adolescente de enganar, manipular, mentir.

A compreensão acerca deste comportamento "manipulador" de S2 é necessária para compreensão dos dados encontrados através de testes estatísticos.

Utilizando o teste não-paramétrico de Spearman foram encontradas correlações negativas entre alguns comportamentos do terapeuta e do cliente nas sessões de psicoterapia:

- Informação do terapeuta e Sentimento Positivo do Cliente $(\rho=-.858)$

- Interpretação do terapeuta e Sentimento Positivo do Cliente $(\rho=-.807)$

- Recomendação do terapeuta e Sentimento Positivo do Cliente $(\rho=-.685)$

Encontraram-se as seguintes correlações positivas:

- Informação do terapeuta e culpar do cliente $(\rho=.611)$ 
- Reprovação do terapeuta e culpar do cliente $(\rho=.619)$

Como se tem a hipótese de que S2 tinha seu comportamento infrator reforçado pelo comportamento da terapeuta de fornecer informação, seria difícil que ele apresentasse comportamentos de expressão de sentimento positivo em relação ao mesmo comportamento da terapeuta, especialmente considerando que sentir é, em parte, um comportamento respondente. É pouco provável que sentimentos positivos e comportamento infrator façam parte da mesma classe de respostas. Essa é provavelmente a explicação para a correlação negativa (-.858) encontrada entre informação do terapeuta e sentimento positivo de S2.

Já para a correlação negativa encontrada entre Interpretação do terapeuta e sentimento positivo do cliente existem outras hipóteses. É preciso expor a definição do comportamento do terapeuta de "Interpretação". "Verbalizações nas quais o terapeuta descreve, supõe ou infere relações causais e/ou explicativas (funcionais, correlacionais, ou de contigüidade) a respeito do comportamento do cliente ou de terceiros ou identifica padrões de interação do cliente e/ou de terceiros." (Zamignani, 2007).

Partindo desta definição é possível supor que quando a terapeuta utilizava descrições de relações causais a respeito do comportamento de S2, aproximando-se de fato de seus comportamentos-problema, ele cessava a emissão de comportamentos que julgava serem os esperados, como por exemplo, a expressão de sentimentos positivos que em alguns momentos era reforçada pela terapeuta. Ou seja, ele cessava a emissão de comportamentos quando percebia que poderia ter suas mentiras (fingir expressão de sentimento positivo) descobertas. Poderia assim ser entendida a correlação negativa apontada pelo teste estatístico. 
Seguindo o mesmo padrão comportamental, quando a terapeuta fazia uso de recomendações que não atendessem às expectativas de S2 e pudessem impedir o alcance de seus objetivos de enganar e mentir, o mesmo parava novamente de emitir comportamentos adequados, especificamente o de expressar sentimentos positivos. Mais uma relação negativa apontada pelo teste estatístico (-.685).

Contudo a convicção e genuinidade aparentes com que S2 expressava-se em alguns momentos ofuscou, na época dos atendimentos, esta análise atual. Alguns exemplos destes comportamentos de S2 serão expostos com a finalidade de explicitar a complexidade deste padrão comportamental descrito na literatura forense como psicopatia (Hare, 1991; Caldwell, M. F. et al.,2007; Flight e Forth, 2007). A carta transcrita (Figura 8) destinava-se a um padrinho do programa de egressos que ajudava com os custos de moradia de S2. Surpreendente é saber que na mesma semana que escreveu esta carta S2 entrou em contato com traficantes para vender drogas, pois achava que estava ganhando muito pouco.

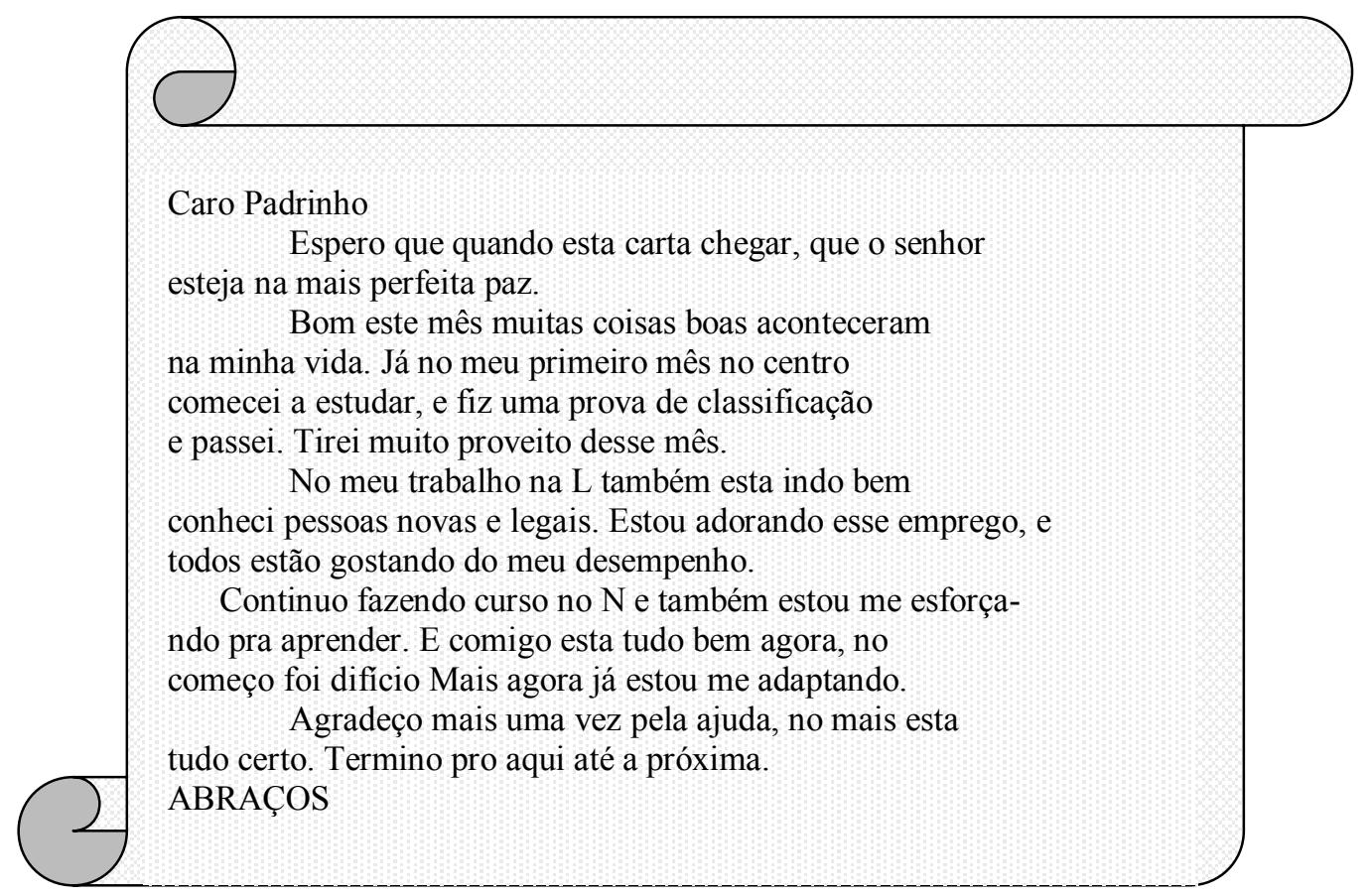

Figura 8. Carta de S2 ao padrinho do programa de egressos em abril de 2006. 
Outro exemplo interessante é uma das cartas de agradecimento entregue para a terapeuta pouco antes do desinternamento de S2 (Figura 9).

\begin{abstract}
S2 Vitória!!! • Para Giovana. Com carinho
Giovana, sei que você esta surpresa! Mas quero aproveitar essa ocasião especial para te omenagiar e agradecer por tudo que você está fasendo por mim. Você pra mim foi uma das poucas pessoas que apareceram em minha vida que se dedicaram a me ajudar nas horas dificeis de tristeza, solidão, sofrimento, até mesmo nas horas de raiva. odio. Enfim de tudo que só me trazia infelicidade. Você apareceu no meu caminho como uma luz libertadora das trevas. Me resgatando da escuridão, me levando para o paíz das maravilhas. Mostrando pra mim o mundo que eu não conhecia. Agora, depois de tudo isso, só me resta te saudar com um forte abraço. Te agradecendo por tudo, e te desejando toda a felicidade do mundo. Felicidade para você! Já não te considero mais como uma .... terapeuta, mas sim como uma AMIGA!
\end{abstract}

Figura 9. Carta entregue para Terapeuta algumas semanas antes do desinternamento de S2.

As correlações positivas indicadas pelo teste estatístico (Informação do terapeuta e culpar do cliente $\rho=.611$; Reprovação do terapeuta e culpar do cliente ( $\rho$ $=.619$ ) indicam comportamentos do terapeuta que aumentavam na medida em que aumentava a ocorrência de comportamentos do cliente de culpar os outros pelos próprios atos, não assumindo responsabilidade sobre os mesmos. Pode-se inferir a existência de duas direções nestas relações, por exemplo, quando o cliente culpava os demais pelos próprios problemas a terapeuta consequenciava reprovando este comportamento ou quando a terapeuta utilizava de reprovações o cliente justificava-se culpando os demais. O mesmo poderia ocorrer com os comportamentos informação do terapeuta e culpar do cliente.

Apesar da existência do diagnóstico psiquiátrico (F 60.2) (DSM-IV-TR, 2002) é possível proceder a uma análise dos comportamentos de S2 partindo de sua história de aprendizagem, mais especificamente compreendendo as práticas educativas com as quais os pais de S2 o criaram. Assim, parece relevante salientar que o pai dele usava-o em contravenções desde os três anos de idade, havendo inclusive relatos de que 
levava o filho para prostíbulos, onde outros homens abusavam sexualmente do menino. Este tipo de abuso infantil também está presente no histórico de S8, outro jovem com o mesmo tipo de diagnóstico de transtorno anti-social de personalidade (F 60.2) (DSMIV-TR, 2002) com características da chamada "psicopatia".

Tabela 6. Práticas educativas dos cuidadores de S2 avaliadas através do Inventário de Estilos Parentais.

\begin{tabular}{|c|c|c|c|c|c|c|c|c|}
\hline IEP S2 & : & 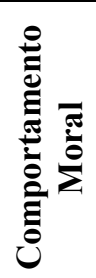 & 兽 & 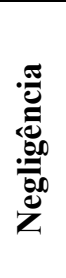 & 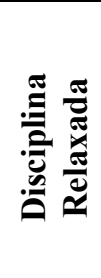 & 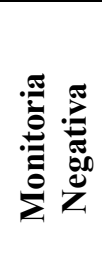 & 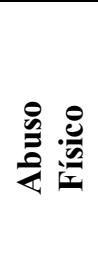 & IEP \\
\hline IEP Materno & 4 & 4 & 6 & 6 & 9 & 7 & 7 & -27 \\
\hline IEP Paterno & 1 & 2 & 8 & 10 & 0 & 3 & 12 & -30 \\
\hline
\end{tabular}

O índice total do IEP materno e do paterno indicavam Estilo Parental de Risco. Sobre as práticas educativas maternas (Tabela 6) é preciso frisar que todas elas são de alto risco. Observando-se a pontuação das práticas positivas, monitoria positiva e comportamento moral, aquelas que contribuem para o desenvolvimento de auto-estima positiva, habilidades pró-sociais, empatia, valores morais e repertório para resolução de problemas, a mãe do adolescente obteve quatro pontos em cada uma delas. Quando se fala de monitoria positiva materna, qualquer valor igual ou abaixo de oito pontos já indica grande risco para o desenvolvimento de comportamentos anti-sociais. O mesmo ocorre para o comportamento moral materno quando obtém sete ou menos pontos.

A Tabela 6 apresenta os valores brutos que indicam risco tanto para práticas maternas quanto para paternas. Observando a coluna referente aos valores de risco para as práticas paternas é possível afirmar que também as práticas do pai de S2 (Tabela 6) estão todas na faixa de risco, exceto a disciplina relaxada e a monitoria negativa.

As práticas educativas negativas possuem efeito direto na contribuição ao desenvolvimento de comportamentos anti-sociais, ao passo que as práticas 
educativas positivas inibem estes comportamentos e proporcionam a aprendizagem de comportamentos pró-sociais (Gomide, 1998, 2001). Sendo assim S2 foi criado em rico substrato para o desenvolvimento de comportamento anti-social.

O que não se pode afirmar, devido à escassez de estudos, são quais práticas contribuem diretamente para o desenvolvimento do transtorno de personalidade anti-social. Alguns estudiosos do tema defendem a existência de um componente neurobiológico na etiologia do quadro (ex.: Morana, 2003; Raine, 1993 apud Vien \& Beech, 2006; Blair, Morris, Frith, Perrett, \& Dolan, 1999 apud Vien \& Beech, 2006; Patrick, 1994 apud Vien \& Beech, 2006), afirmando, portanto que há uma preponderância biológica sobre o aspecto comportamental do transtorno. Contudo, nas histórias de vidas de adolescentes atendidos pelo Programa de Alto-risco, do qual a psicoterapia em discussão fazia parte, foi possível encontrar alguns aspectos comuns quanto às práticas educativas.

Importante frisar que estes dados não se resumem às histórias dos dois participantes deste estudo (S2 e S8) diagnosticados com o transtorno F 60.2 (DSM-IVTR, 2002), mas sim foram aspectos comuns encontrados nos relatos e observações de mais três adolescentes com características comportamentais semelhantes e que estavam internados na mesma unidade, sendo então fatos comuns a cinco histórias de vida.

Todos eles possuíam histórico de práticas educativas maternas com altos índices de negligência e abuso físico, bem como índices elevados de punição inconsistente. Além, disso os relatos destes jovens traziam conteúdo que explicitava a ocorrência de abuso psicológico grave e abuso sexual facilitado pela mãe por omissão e negligência.

Destes cinco jovens é possível afirmar que nenhum teve a presença do pai após os seis anos de idade, e até o ponto em que quatro deles tiveram, todos eles 
sofreram abuso físico combinado ao psicológico configurando verdadeiras situações de tortura por parte destes pais.

É relevante expor que a obtenção deste tipo de dados é dificultada pela vergonha que a humilhação fruto de inúmeros abusos causa. Estes relatos geralmente aconteciam apenas uma vez e depois os adolescentes negavam-se a repeti-los e por vezes até negavam que tivessem feito tais relatos. Outro fator que parece importante é que estes fatos eram relatados apenas em situação terapêutica adequada, ou seja, o mesmo adolescente que já havia passado por diversas psicólogas e não havia contado tais fatos, contava-os para a psicóloga especialista que estava atenta e conhecia o assunto.

Tais relatos geralmente vinham acompanhados de manifestações emocionais e quando isto não ocorria durante a sessão estas emoções se manifestavam após as mesmas de forma agressiva e incontida, provocando na equipe de segurança do local reações de desconfiança quanto aos procedimentos utilizados e o que estavam gerando nos adolescentes. Cabe aqui dizer que esta é uma variável importante, pois os demais membros das equipes que trabalham com esta população e que interagem diretamente com estes jovens precisam ser treinados a fim de agir de maneira contingente ao tratamento realizado, não interferindo negativamente e prejudicando-o.

O que torna essas reações relevantes do ponto de vista do padrão comportamental destes adolescentes deve-se ao fato de que pouco era possível observar respostas emocionais, principalmente àquelas ligas à ansiedade, no repertório comportamental de cada um deles. Serafim (2005) concluiu em uma de suas pesquisas com homicidas psicopatas que estes indivíduos tendem a expressar baixo nível de ansiedade, pois vivenciam de forma reduzida ou indiferente as sensações subjetivas de 
tensão e apreensão percebidas e não percebem como ameaçadoras uma ampla faixa de situações ambientais, que assim seriam percebidas pelas demais pessoas.

\section{S3: O MALANDRO}

No ano de 2006 o adolescente completou 18 anos. Quando a mãe de S3 estava grávida dele, o pai faleceu em decorrência de um tumor cerebral. Já havia mais dois filhos, duas meninas. A mãe casou mais três vezes e teve mais quatro filhos que foram criados pelas respectivas famílias paternas. Em 2004 quando a mãe passou a apresentar graves problemas de saúde, S3 já morava com uma das irmãs, esta tal como o adolescente sempre foi usuária de maconha. Ambas as irmãs são casadas e ambos os cunhados de S3 possuem histórico infracional. Em 2005, já cumprindo medida socioeducativa de internamento $\mathrm{S} 3$ recebeu autorização para visitar a mãe que estava internada com câncer uterino em fase terminal. Alguns dias depois da visita ela faleceu.

S3 recebeu medida socieducativa de internamento devido a um furto qualificado, porém envolveu-se em tumultos na unidade de origem, sendo transferido para outra unidade. Nesta envolveu-se em um homicídio e então no final de 2005 foi transferido para a unidade onde participou da intervenção descrita neste trabalho.

Convém citar que esta foi a segunda medida de internação que o adolescente cumpriu. A primeira deu-se em 2003 pelo ato infracional de roubo e lesões corporais. Naquela ocasião permaneceu interno por nove meses com substituição por liberdade assistida, a qual não chegou a cumprir.

O participante $3(\mathrm{~S} 3)$ passou por 23 sessões de psicoterapia, das quais 11 foram analisadas. O processo psicoterápico foi iniciado em janeiro de 2006.

A Figura 10 abaixo mostra na distribuição linear das sessões, quais as analisadas. 


\begin{tabular}{|l|l|l|l|l|l|l|l|l|l|l|l|l|l|l|l|l|l|l|l|l|l|l|l|}
\hline Sessões & 1 & 2 & 3 & 4 & 5 & 6 & 7 & 8 & 9 & 10 & 11 & 12 & 13 & 14 & 15 & 16 & 17 & 18 & 19 & 20 & 21 & 22 & 23 \\
\hline Analisadas & & & & & & & & & & & & & & & & & & & & & & & \\
\hline
\end{tabular}

Figura 10. Sessões de psicoterapia analisadas do participante S3.

Sobre a sexta sessão $\left(1^{\circ}\right.$ de março $)$ vale citar que foi iniciada com a psicoterapeuta questionando S3 sobre a tarefa de refletir sobre a continuidade da terapia. Discutiu-se a função e objetivos de uma terapia e o papel da confiança na relação terapêutica. S3 fez o pedido de continuar o processo, com a mesma psicóloga, adicionando que tentaria aprender a confiar em alguém que não era do crime.

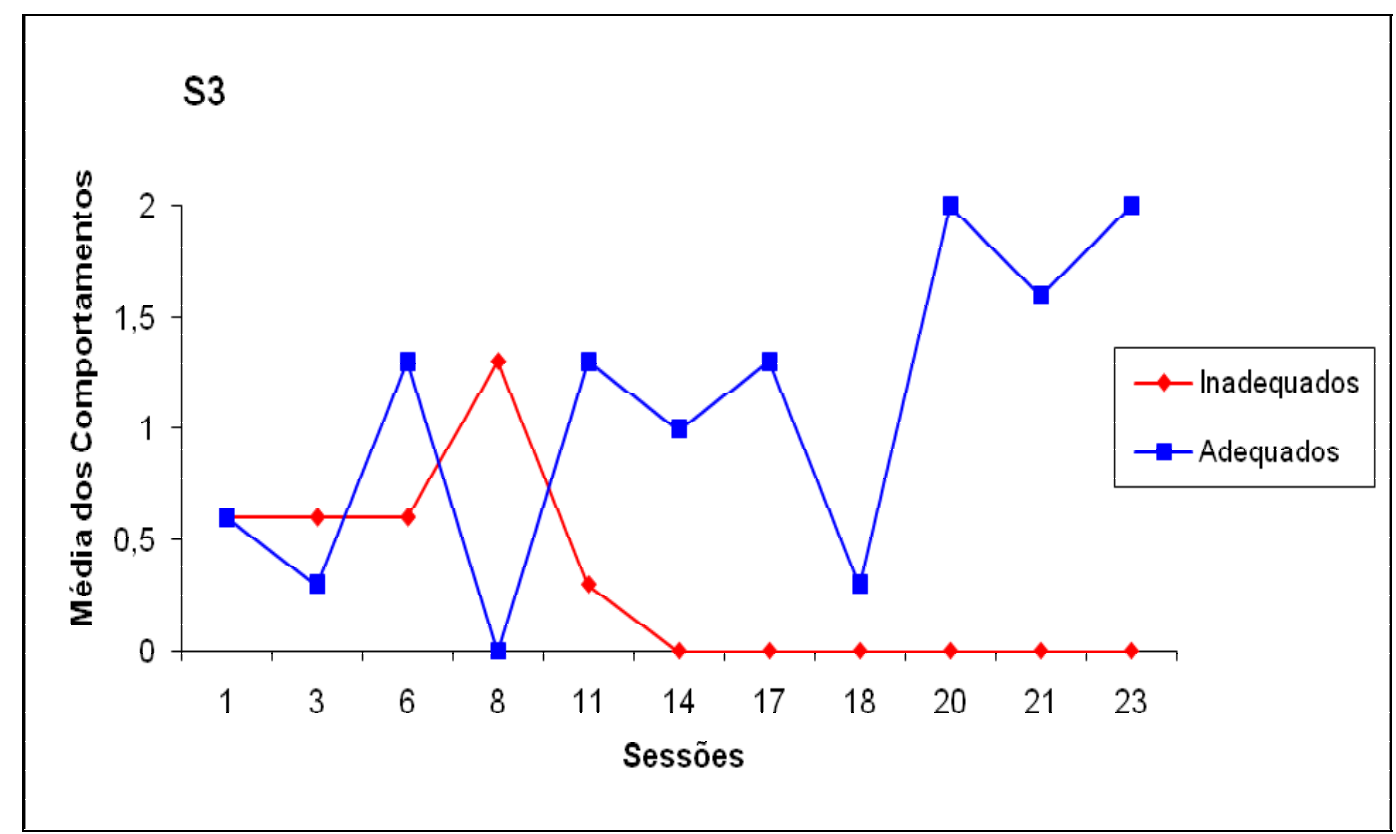

Figura 11. Média dos Comportamentos Inadequados e Adequados de S3 ao longo das sessões.

Com o decorrer do processo S3 passou a demonstrar sentimentos de apreço pela terapeuta, indicativo de vínculo e formação da aliança terapêutica. Então provavelmente o comportamento da terapeuta de Aprovação passa a ter valor reforçador para o cliente. Mais uma vez pode-se inferir uma relação bidirecional entre os comportamentos de aprovação da terapeuta e expressão de arrependimento do cliente, ou seja, quando o cliente demonstra arrependimento este comportamento é seguido pela aprovação do terapeuta e a aprovação do terapeuta sinaliza para o cliente que seu 
comportamento de admitir falhas e erros e arrepender-se por eles seria compreendido e acolhido na sessão de terapia.

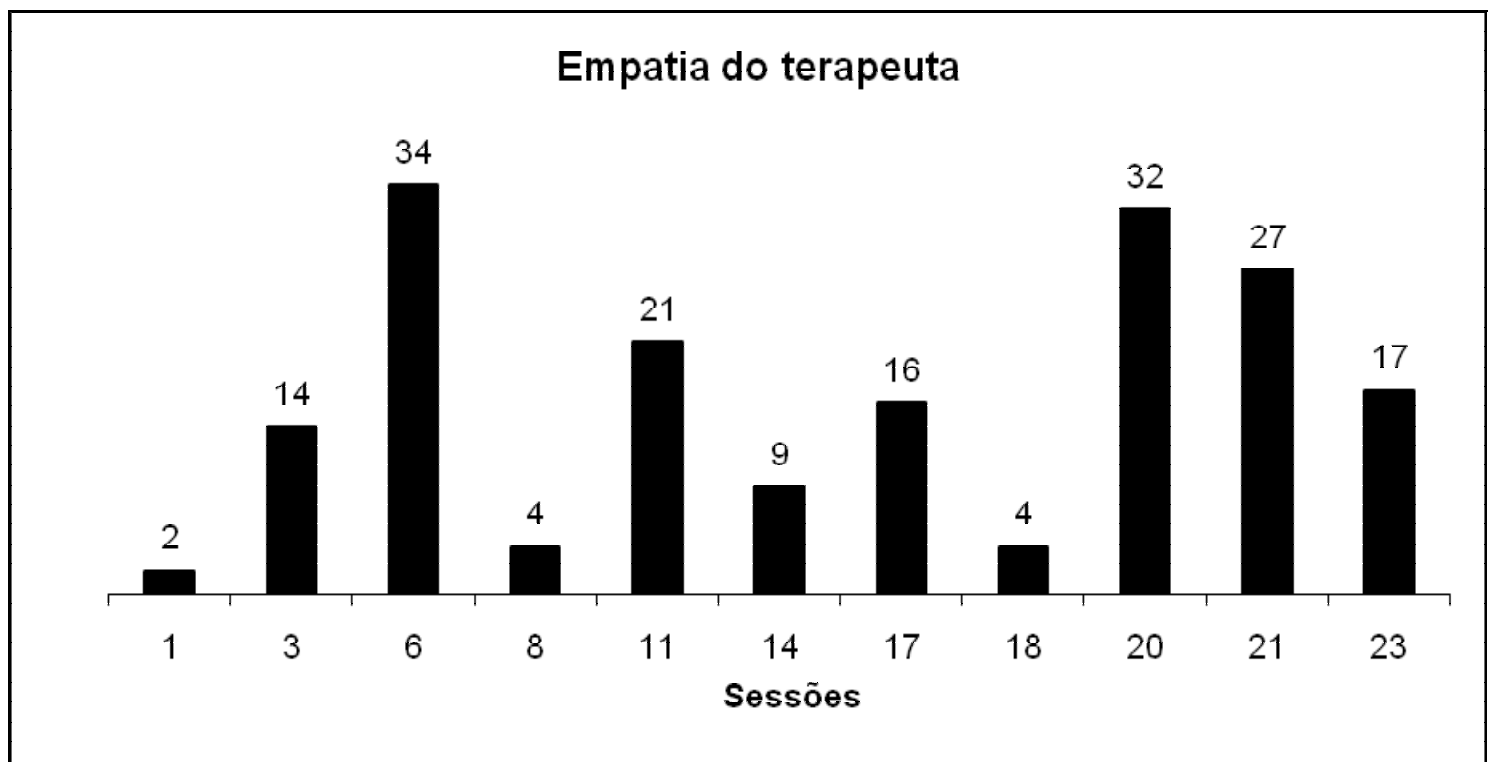

Figura 12. Empatia do Terapeuta ao longo das sessões de S3.

Na sexta sessão (9 de março) (Figura 11), a psicoterapeuta utiliza um número maior de intervenções Empáticas o que possivelmente explica o aumento de comportamentos adequados do cliente naquela sessão. Na sessão seguinte, a oitava, é possível observar (Figura 12) um baixo número de comportamentos de Empatia do psicoterapeuta, que fez mais Solicitações de Relato ao cliente (Figura 13), e diminuíram-se bruscamente os comportamentos adequados do cliente (Figura 10). Na décima primeira sessão, os comportamentos adequados voltam a aumentar, e a taxa de comportamentos Empáticos do terapeuta é mais de quatro vezes maior do que na sessão 8. As sessões 20, 21 e 23, todas com alto número de comportamentos adequados, também apresentam número elevado de comportamentos empáticos do psicoterapeuta (Figura 12). 


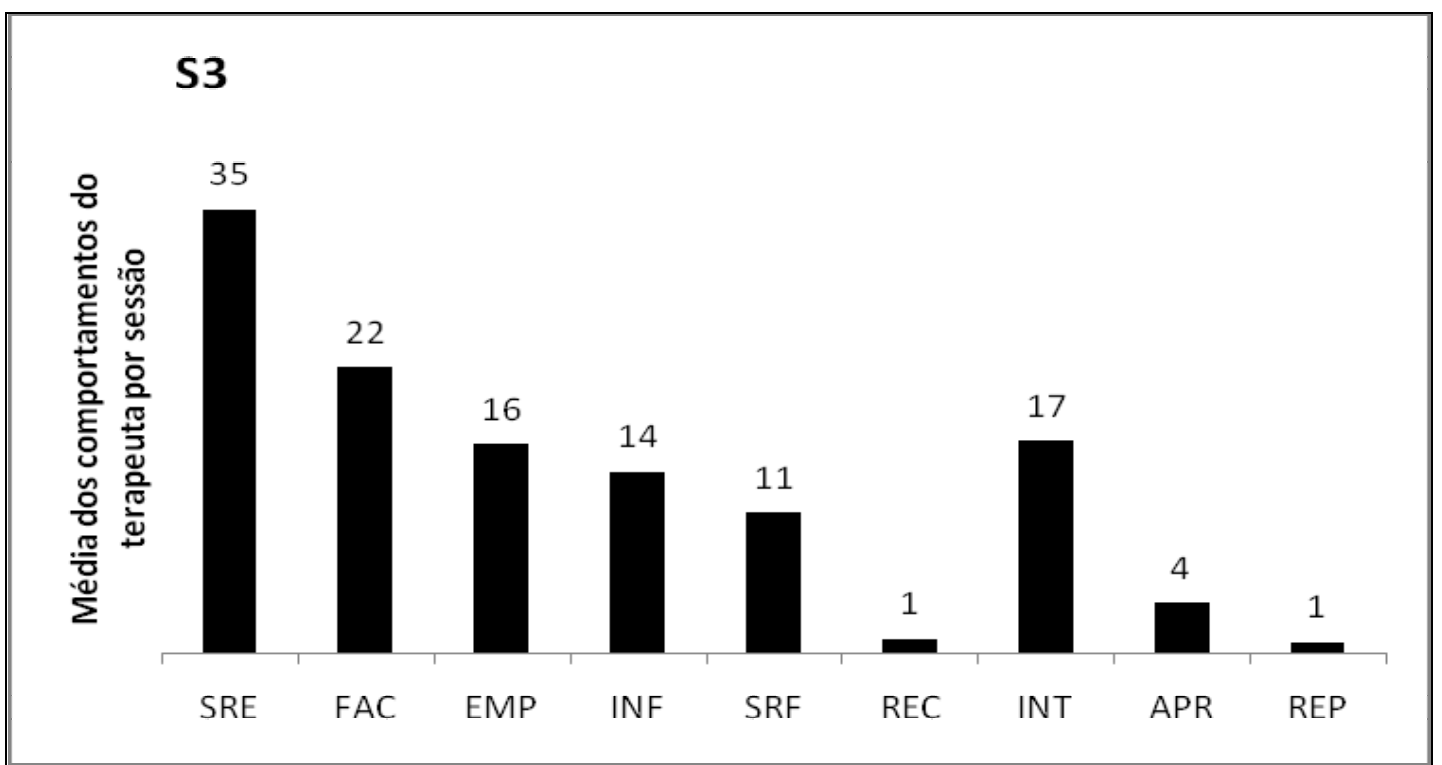

Figura 13. Média dos comportamentos do terapeuta por sessão n processo de S3.

A Figura 13 mostra mais uma vez a alta média de ocorr6encia do comportamento do terapeuta de Solicitar Relato e baixas médias de ocorr6encia de médias de ocorrência de reprovação, recomendação e aprovação. Interessante notar que a média de Interpretação é um pouco mais elevada que a de Empatia e Informação, diferente de outros casos .

Utilizando o teste não-paramétrico de Spearman foram encontradas correlações positivas entre alguns comportamentos do terapeuta e do cliente nas sessões de psicoterapia:

- Empatia do terapeuta e Sentimento Positivo do Cliente $(\rho=.725)$

- Empatia do terapeuta e arrependimento do Cliente $(\rho=.676)$

- Interpretação do terapeuta e sentimento positivo do cliente $(\rho=.679)$

- Aprovação do terapeuta e arrependimento do cliente $(\rho=.786)$

- Reprovação do terapeuta e culpar do cliente $(\rho=.756)$

Também foram encontradas as seguintes correlações negativas:

- Empatia do terapeuta e Hostilidade do Cliente $(\rho=-.642)$

- Solicitação de relato do terapeuta e arrependimento do cliente $(\rho=-.608)$ 
- Interpretação do terapeuta e hostilidade do cliente $(\rho=-.664)$

- Aprovação do terapeuta e hostilidade do cliente $(\rho=-.670)$

A consistência dos comportamentos da terapeuta, descrita em termos de práticas educativas positivas de monitoria positiva e comportamento moral, são evidenciados com a relação positiva encontrada entre o comportamento inadequado do cliente de culpar o outros e a reprovação da terapeuta $(\rho=.756)$. Esta consistência também pode ser inferida a partir de algumas das correlações negativas encontradas através dos testes estatísticos: a empatia do terapeuta e a hostilidade do cliente $(\rho=$ .642) e a interpretação do terapeuta e hostilidade do cliente $(\rho=-.664)$. Em ambas as situações é possível supor que frente à hostilidade do cliente, muitas vezes exacerbada, não era possível a compreensão e interpretação explícitas daquele comportamento no momento em que ocorria, devido às regras de segurança da unidade. Então as sessões eram interrompidas e o assunto era retomado em outra sessão.

As correlações negativas entre solicitação de relato do terapeuta e arrependimento do cliente ( $\rho=-.608)$ e aprovação do terapeuta e hostilidade do cliente $(\rho=-.670)$ podem ser discutidas à luz de características específicas do comportamento de S3 que era um rapaz com baixo repertório de interação social. Portanto, as solicitações de relato da terapeuta inicialmente não eram facilitadoras para comportamentos de S3, mas sim pareciam anteceder longos períodos de silêncio do adolescente. Já a aprovação da terapeuta parece neste caso ter sido um comportamento determinante para a formação de vínculo, pois altos níveis de aceitação se relacionavam com os mais baixos índices de hostilidade deste cliente.

De acordo com o sistema de análise desenvolvido por Zamignani (2007) a categoria de comportamento do terapeuta "Empatia" compreende comportamentos do terapeuta que sugerem expressão de afeto, compreensão e aceitação do cliente. Estes 
comportamentos demonstram que o terapeuta compreendeu os estados internos e/ ou as condições às quais o cliente está exposto, através da validação dos comportamentos do cliente, sejam eles atitudes ou sentimentos, sem julgamento, avaliação ou críticas. Fazem parte desta categoria de comportamento do terapeuta: nomeação de sentimentos, exclamações empáticas com função de denotar interesse do terapeuta, verbalizações de cuidado, auto-revelações empáticas, validação de discordâncias ou críticas do cliente, humor, apoio, comentários de entendimento e paráfrases.

$\mathrm{Na}$ análise estatística do caso S3 é possível notar que a empatia do terapeuta relaciona-se positivamente com expressão de sentimento positivo e expressão de arrependimento, que são comportamentos-alvo no processo, ao passo que possui relação negativa com o comportamento de hostilidade do cliente. Sendo assim é possível presumir que a empatia tem importante papel no processo psicoterápico, seja com estímulo antecedente ou como reforçador para comportamentos adequados do cliente.

Também foram encontradas relações positivas estatisticamente significativas entre outros comportamentos da terapeuta e do cliente que se fazem relevantes discutir. Os comportamentos do terapeuta presentes na categoria "Interpretação" são definidos como verbalizações pelas quais o psicoterapeuta descreve, supõe ou infere relações causais e/ou explicativas (funcionais, correlacionais, ou de contigüidade) a respeito do comportamento do cliente ou de terceiros ou identifica padrões de interação do cliente e/ou de terceiros (Zamignani , 2007).

Vale ainda citar as sub-categorias de Interpretação:

- descrição explicativa de relações entre ações (do cliente e/ou de terceiros) e outros eventos ou ações (se... então...);

- descrição de contigüidade entre ações (do cliente e/ou de terceiros) e outros eventos ou ações ( o evento X ocorre quando Y ocorre...); 
- descrição de regularidades ou padrões recorrentes de ações do cliente e/ou de terceiros;

- diagnóstico;

- devolutiva de avaliação padronizada;

- estabelecimento de síntese ou conclusões;

- descrição por meio de metáforas ou analogias explicativas;

- inferências;

- confrontação.

- normalização

Com o cliente S3 as sub-categorias mais utilizadas foram as de descrição explicativa de relações entre ações, descrição de contigüidade entre ações, descrição de regularidades ou padrões recorrentes de ações do cliente e/ou de terceiros, estabelecimento de sínteses e conclusões, inferências e confrontação, como pode ser observado no seguinte exemplo:

Terapeuta: "Pois é S3, parece que todas as vezes que eu toco nesse assunto você se fecha... então alguns dias depois da tua sessão, às vezes até no mesmo dia, você apronta alguma coisa e recebe uma medida disciplinar. Talvez você não se sinta bem, sei lá, sinta alguma coisa, e ao invés de me dizer isso (S3 balança a cabeça negativamente). Por favor, deixe eu acabar antes de você já dizer que não é isso. Essa é outra coisa que você sempre faz... Quando eu falo alguma coisa sobre você, você nem me escuta e já nega. Bem, então, ao invés de me dizer essas coisas você provoca uma situação porque sabe que desta forma, estando de medida, sua terapia será mais curta e assim não teremos tempo para voltar ao assunto que você parece querer evitar... Imagino que seja bem doloroso mesmo. Agora se você topar poderemos fazer como eu fiz hoje. Sempre que isto estiver acontecendo eu te mostro na hora. Se você não quiser continuar no assunto, você vai me dizer isso e eu vou te respeitar. Tá? (...) Aí o que eu vou fazer é tentar entender como você está se sentindo, e assim você vai deixando eu te conhecer melhor. Se eu não conhecer você, não posso te ajudar.” 
Esta intervenção faz parte de uma sessão realizada no final do mês maio (sessão cujos dados não foram analisados). Através da Figura $14^{13}$ é possível observar que o número de comportamentos inadequados que geravam medidas disciplinares diminuiu após a intervenção. Contudo no mês de Julho a ocorrência destes comportamentos voltou a crescer. Este aumento estava relacionado com o fato de S3 ter conquistado o direito de fazer um curso profissionalizante. Porém, a realização do curso se dava em duplas e S3 deveria fazer o curso com um adolescente (Y) que tinha problemas com outro adolescente que "liderava" a cadeia $(\mathrm{O})$. S3 passou a sofrer pressão de $\mathrm{O}$ para abandonar o curso ou então aproveitar a ocasião e agredir Y durante o curso. Carente de repertório pró-social não infrator, S3 viu-se em situação de impasse: caso contasse à terapeuta o que estava acontecendo e os demais adolescentes descobrissem, ele seria considerado um traidor; caso agredisse $\mathrm{Y}$ também seria prejudicado perdendo o curso; se não atendesse à solicitação de $\mathrm{O}$ também seria considerado um traidor. O que ele fez então foi apresentar vários comportamentos inadequados de pequena gravidade (cantar muito alto, gritar palavras obscenas para as presas da penitenciária feminina que ficava ao lado da unidade, negar-se a tomar banho, negar-se a cortar o cabelo e fazer a barba) que faziam com que ele recebesse medidas disciplinares que o impediam de ir ao curso. Desta forma ele tinha justificado frente aos colegas porque não agredira $\mathrm{Y}$.

Quando a terapeuta percebeu o que estava acontecendo S3 recebeu orientações e fez treino de resolução de problemas, priorizando sempre o próprio crescimento e bem-estar. S3 continuou no curso e em agosto não recebeu nenhuma medida disciplinar até o final do curso.

\footnotetext{
${ }^{13}$ Esta figura é fruto de um registro diário de comportamento inadequados que era realizado por educadores sociais na unidade. Não foi possível obter estes dados de todos os adolescentes, apenas de S3, S6 e S7.
} 


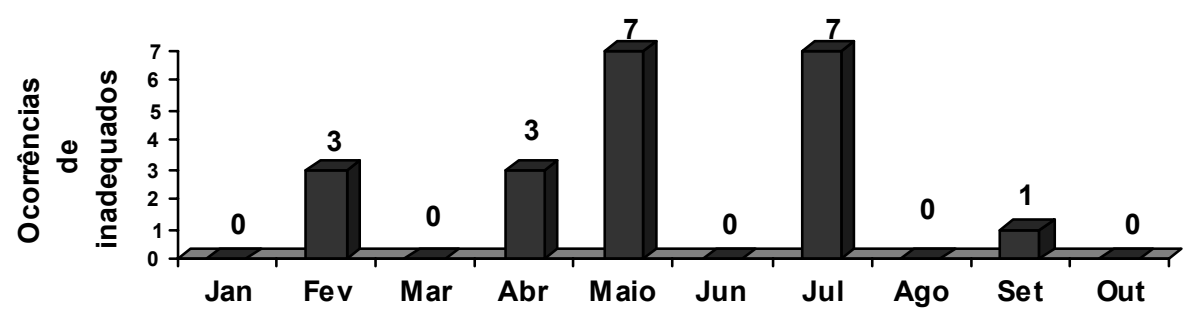

Figura 14. Registros Diários de Comportamentos Inadequados de S3.

Sobre as práticas educativas dos cuidadores de S3, mais uma vez, há a constatação da presença maciça de práticas de risco tendo como índice total Estilo Parental de Risco (Gomide, 2006) (Tabela 7). Ou seja, pouquíssimas práticas educativas positivas, que são aquelas que desenvolvem os comportamentos pró-sociais, valores morais, capacidade de resolução de problemas e auto-estima elevada, e muitas práticas educativas negativas que favorecem o desenvolvimento de comportamentos anti-sociais.

Tabela 7. Práticas educativas dos cuidadores de $\mathrm{S} 3$ avaliadas através do Inventário de Estilos Parentais.

\begin{tabular}{|c|c|c|c|c|c|c|c|c|}
\hline IEP S3 & 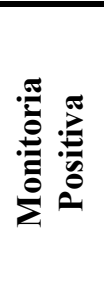 & 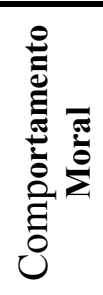 & 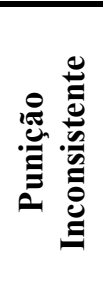 & 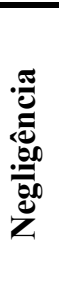 & 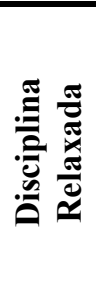 & 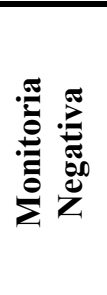 & 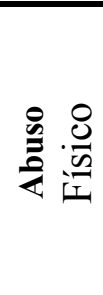 & IEP \\
\hline IEP Materno & 1 & 2 & 0 & 11 & 7 & 2 & 3 & -20 \\
\hline IEP Irmã & 3 & 2 & 2 & 7 & 5 & 3 & 2 & -17 \\
\hline
\end{tabular}

As práticas educativas tanto da mãe quanto da irmã do adolescente evidenciam as bases propicias para o desenvolvimento do comportamento anti-social do mesmo, fundamentando-se principalmente na negligência, na disciplina relaxada e no abuso físico e na ausência de comportamento moral e da monitoria positiva.

A combinação destas práticas resulta em não cumprimento de regras, desrespeito à autoridade, manipulação emocional, auto-estima rebaixada, comprometimento das expectativas de futuro, desmotivação para tarefas complexas, insegurança, falta de confiança nas pessoas e falta de empatia (Gomide, 2004). 


\section{S4: O MENINO E "SNYRF", O RATO}

Este adolescente, que em 2006 tinha 20 anos de idade, foi o que teve o processo de psicoterapia mais longo de todo o trabalho.

Sua apreensão ocorreu em março de 2004 e sobre ele recaíam as seguintes infrações: furto, injúria, ameaça, tentativa de homicídio simples e atentado violento ao pudor.

Dia 11.03.2005
Redação da Minha Familia
A minha familia é bem homilde e além de ser homilde é tudo que eu tenho
apesar de não ter meus pais eu tenho uma querida vó e o meu vô que me
criaram desde pequeno, tenho tambem varias tias e tios nas são poucos que
eu tenho consideração porque eles tambem não me consideram tambem tenho
bastante primeiros e primas eu bolo bastante idéia com quase todos tem só
um primo que eu não se acerto com ele por que já estou a 1 ano preso por
causa dele. tem uma prima minha que eu considero muito igal a minha mãe
ela é casada tem dois filhos e sempre que pressisei ela me ajudo com conselho
e quando eu era pequeno ela sempre me deu a maior força tambem tenho
duas irmãs e um irmão todos eles é mais novo do que eu, tem uma irmã que já
faz uns 10 anos que eu não a vejo. e tem o meu irmão que mora em [C] que a
ultima vez que encontrei com ele foi em 2003 que eu fui lá na casa da minha
tia que cuidou dele desde 1 ano de idade e que ele considera ela igual a mãe e
depois do meu irmão vem a minha irmã mais nova que é irma só por parte de
mãe e esta mora com a avó dela. tem um tio meu que é foragido da policia
que eu bólava algumas ideias com ele só que quando ele tomava uns goró ele
queria quebrar a casa da minha e ai eu dava umas coronha de revolver nele
mas agora desde 2002 que ele esta foragido sem vir na casa da minha vó, só
que a minha vó sofre muito por isso porque ele esta foragido e eu estou preso,
que ele consol de dar conselhos mas não valia nada agora ele diz que tambem

S4 fazia uso de álcool, drogas e tabaco desde aproximadamente os seis anos de idade. Aos nove anos o uso já era freqüente e aos doze seu comportamento já 
indicava dependência. Este severo quadro estava intimamente entrelaçado com a vida infratora do adolescente.

O adolescente foi apreendido em março de 2004 e permaneceu provisoriamente internado até agosto do mesmo ano. Foi liberado com medida socioeducativa de liberdade assistida que não foi cumprida. Após um mês e vinte e quatro dias foi expedido mandado de busca e apreensão revogando a medida de liberdade assistida. S4 foi internado em uma grande unidade do interior do estado e devido à sua participação em uma rebelião foi transferido em fevereiro de 2005 para a unidade onde foi realizado este trabalho.

Os pais de S4 são falecidos. Ambos foram assassinados. O pai faleceu quando S4 tinha oito anos e a mãe um ano depois. Desde a morte do pai S4 residia com os avós maternos, ambos lavradores, que na época moravam em uma casa emprestada juntamente com um tio do adolescente. Este tio abusou sexualmente de S4 e agredia fisicamente a avó do jovem. Os avós relataram que ele sempre fora uma criança difícil de controlar e o uso de álcool e drogas agravou-se após a morte da mãe. S4 conta que seu envolvimento com atos infracionais sempre esteve ligado ao uso de entorpecentes (maconha, cocaína e crack) e ao álcool, bem como às pessoas envolvidas com o tráfico e consumo de drogas. Com pouca instrução e sem orientações sobre como lidar com o neto, os avós não conseguiram fazer com que S4 permanecesse na escola, o que certamente contribuiu para seu histórico infracional. S4 perdeu o contato com os irmãos mais novos, uma menina e um menino, doados a outras pessoas da família na ocasião do falecimento da mãe.

S4 iniciou a psicoterapia em junho de 2005 e durante dois meses disse para a terapeuta que estava ali para agradar à coordenadora do programa e conseguir sua liberdade. Declarava sua vontade de usar drogas e beber, bem como o desejo de acertar 
contas com pessoas ligadas ao crime, o que faria assim que saísse da internação. Três meses depois, depois de vários tumultos na unidade e de inúmeras punições através de medidas disciplinares S4 pediu ajuda para modificar seus comportamentos e valores. $\mathrm{O}$ processo psicoterápico foi marcado por duas fugas de S4 da unidade, sendo que em ambas ele voltou após conversar com a terapeuta, uma vez pessoalmente na rua e outra pelo telefone. Ela explicou para ele quais as possíveis conseqüências da fuga, e, ao mesmo tempo demonstrando preocupação pelo cliente.

Outro fato interessante foi que a sessão na qual S4 pediu ajuda para modificar seus comportamentos, sucedeu à descoberta que ele fizera de que a terapeuta tinha a mesma idade que sua mãe teria caso estivesse viva.

O participante 4 (S4) passou por 39 sessões de psicoterapia, das quais 14 foram analisadas. O processo teve inicio no mês de junho de 2005.

A Figura 15 abaixo mostra na distribuição linear das sessões, quais as analisadas.

\begin{tabular}{|c|c|c|c|c|c|c|c|c|c|c|c|c|c|c|c|c|c|c|c|c|c|c|c|}
\hline Sessões & 1 & 2 & 3 & 4 & 5 & 6 & 7 & 8 & 9 & 10 & 11 & 12 & 13 & 14 & 15 & 16 & 17 & 18 & 19 & 20 & 21 & 22 & 23 \\
\hline Analisadas & & & & & & & & & & & & & & & & & & & & & & & \\
\hline & 24 & 25 & 26 & 27 & 28 & 29 & 30 & 31 & 32 & 33 & 34 & 35 & 36 & 37 & 38 & 39 & & & & & & & \\
\hline
\end{tabular}

Figura 15. Sessões de psicoterapia analisadas do participante S4.

Cabe ressaltar alguns fatos ocorridos entre a sessão 18 e a 29, pois dentre elas não há sessões analisadas. No dia $1^{\circ}$ de março (sessão 19) realizou-se a chamada “terapia em contenção", sessão realizada como única atividade quando os adolescentes encontravam-se em medida disciplinar de contenção. Tinha menor duração e servia para que o jovem realizasse reflexões sobre os comportamentos que tinham levado ao recebimento da medida disciplinar. S4 foi encontrado com um "estoque"14 em seu alojamento, mas não fala do fato e concentra-se em criticar os educadores e expressar

\footnotetext{
${ }^{14}$ Faca rústica, ou qualquer objeto que se adapte para transformá-la em instrumento pontiagudo e cortante. (Houaiss, versão online)
} 
raiva pelos mesmos. A psicoterapeuta insistiu para que ele refletisse sobre a responsabilidade do ocorrido, e como o jovem continuou a hostilizar os educadores, ela encerrou a sessão dizendo: "Você está, como em outras vezes, responsabilizando o outro..."

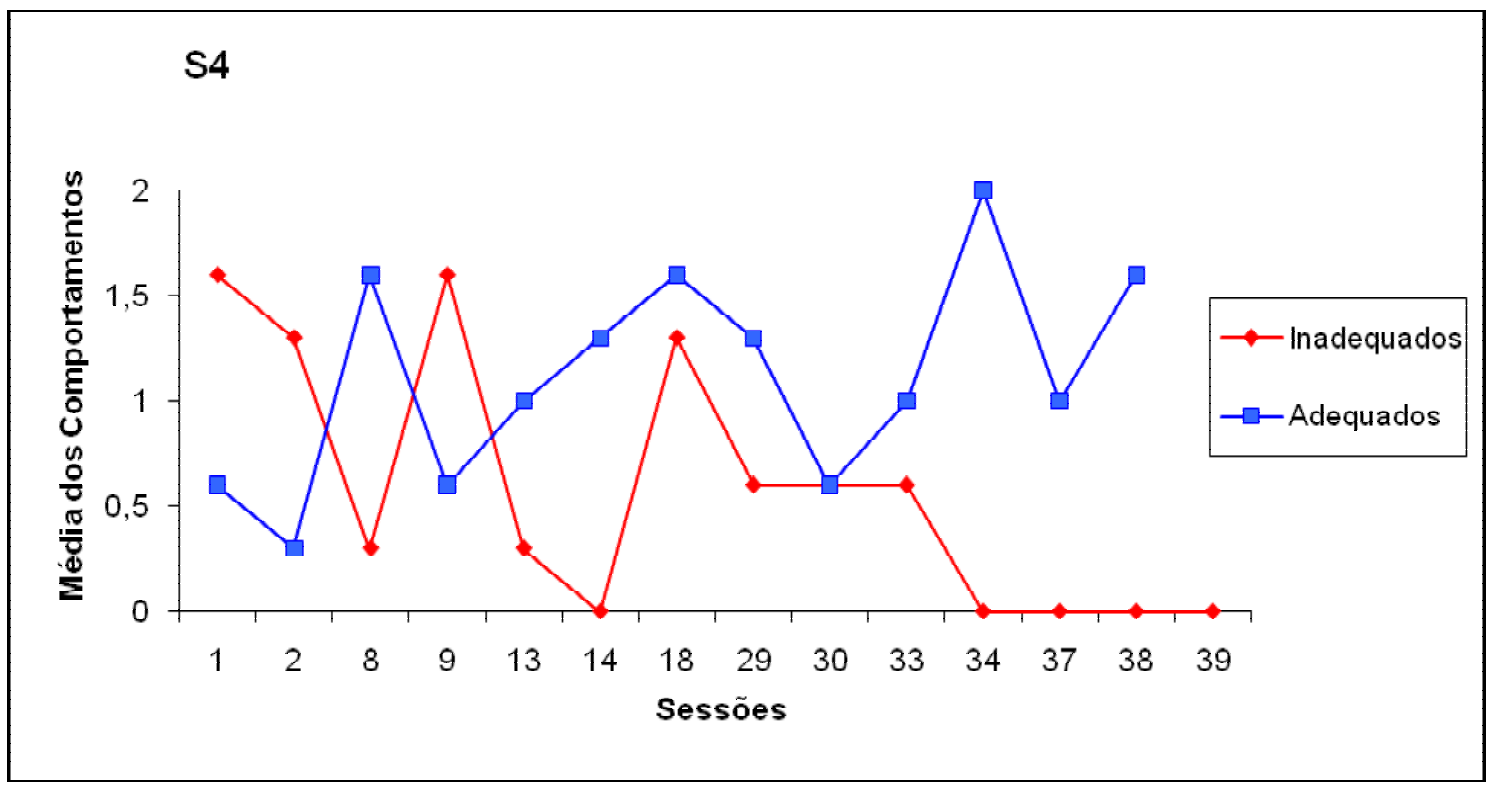

Figura 16. Média dos Comportamentos Inadequados e Adequados de S4 ao longo das sessões.

Na Figura 16 onde estão expostas as médias dos comportamentos adequados e inadequados de S4 ao longo das sessões é possível observar que mesmo os comportamentos adequados oscilavam frequentemente, transparecendo os dilemas que S4 vivia, de acordo com relatos dele mesmo. Tais dilemas referiam-se às situações novas imbuídas de confiança e aceitação pelas quais ele passava, pois na medida em que apresentava os comportamentos adequados em situações cotidianas do internamento S4 conquistava o direito de fazer mais atividades, tinha mais contato com as pessoas e permanecia mais tempo fora do alojamento.

Inicialmente, tanto no processo de S4 como no dos demais adolescentes, a alta ocorrência de solicitações de relato (Figura 17) parece favorecer o aparecimento de comportamentos inadequados de mentir e culpar do cliente, predominantes no início 
das psicoterapias (Figura 15). Já no caso da solicitação de reflexão (Figura 17), ela parece tanto anteceder quanto consequenciar o comportamento de culpar do cliente, já que era preciso solicitar reflexão também sobre o próprio comportamento de culpar para que o jovem aprendesse a discriminar este comportamento.

A relação encontrada entre o comportamento de facilitação da terapeuta e o comportamento de expressão de sentimento positivo do cliente parece evidente uma vez que havia dificuldade nítida do adolescente em externalizar este comportamento.

Estes comportamentos do terapeuta, facilitação e empatia por exemplo, parecem ilustrar o conceito skinneriano de audiência não-punitiva, segundo o qual o terapeuta se constitui em um agente não punidor que frequentemente responde ao cliente de forma incompatível com a punição, proporcionando assim o aparecimento dos comportamentos do cliente punidos pela sociedade e tornando possível um trabalho mais eficaz de modificação comportamental (Skinner, 1953).

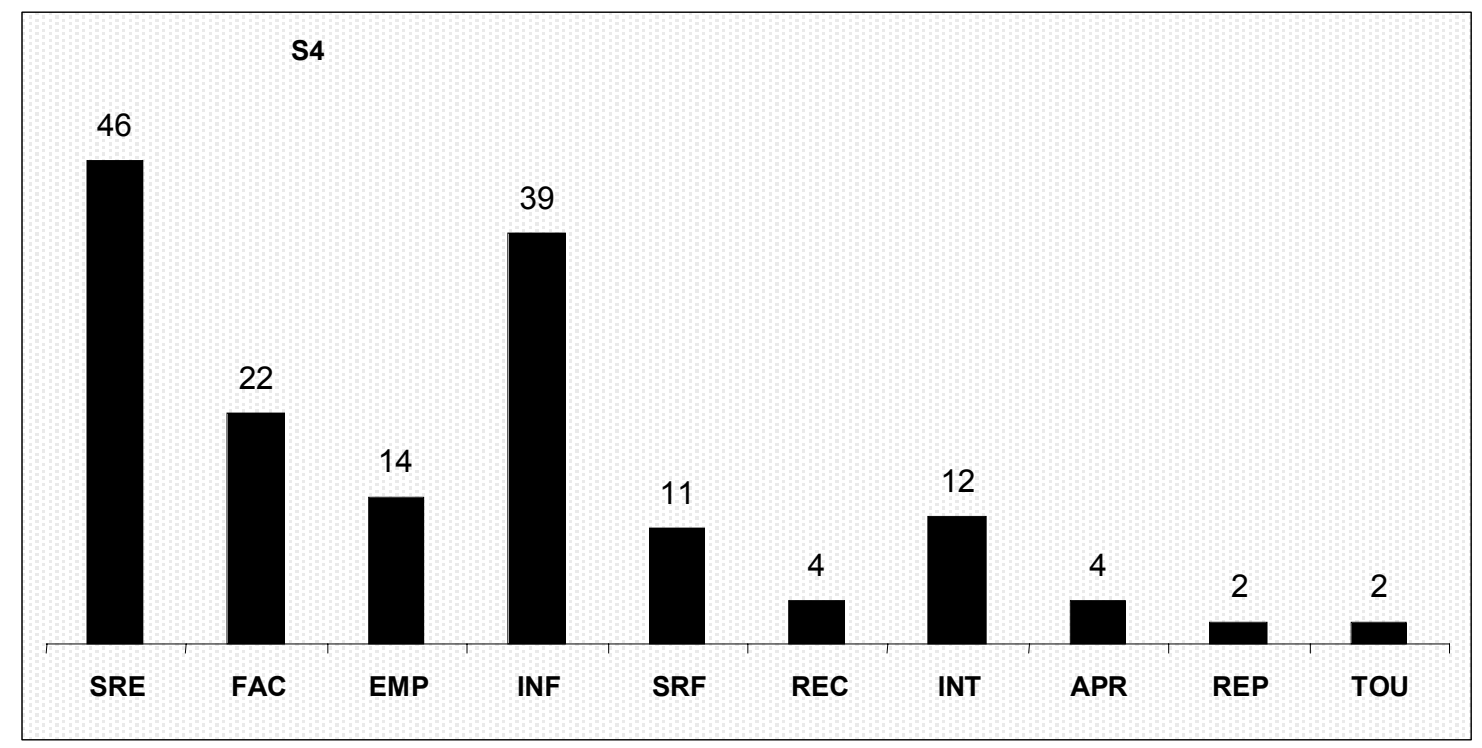

Figura 17. Média dos comportamentos do terapeuta por sessão no caso S4.

Ainda relacionadas a este conceito de Skinner (1953) parecem estar as baixas médias dos comportamentos do terapeuta de reprovar e fazer recomendações (Figura 17), atestando a necessidade de audiência não-punitiva na psicoterapia, 
Utilizando o teste não-paramétrico de Spearman foram encontradas correlações positivas entre alguns comportamentos do terapeuta e do cliente nas sessões de psicoterapia:

- Solicitação de relato do terapeuta e mentira do Cliente $(\rho=.633)$

- Solicitação de relato do terapeuta e culpar do Cliente $(\rho=.641)$

- Facilitação do terapeuta e sentimento positivo do cliente $(\rho=.608)$

- Solicitação de Reflexão do terapeuta e culpar do cliente $(\rho=.668)$

Também foi encontrada a seguinte correlação negativa:

- Recomendação do terapeuta e Sentimento Positivo do Cliente $(\rho=-.608)$.

Esta correlação negativa pode ser explicada pela conduta opositora de S4, que demonstrava irritação e descontentamento sempre que a terapeuta lhe fazia uma recomendação. Contudo, frente à resistência de $\mathrm{S} 4$ em aceitar recomendação, ele ainda assim recebia novas recomendações para que pudesse lidar com este sentimento.

Sobre as correlações positivas que envolvem comportamentos do terapeuta e comportamentos inadequados do cliente é preciso analisar novamente o contexto de não-aversividade no qual deveriam ocorrer as interações entre cliente e terapeuta. A solicitação de relato do terapeuta relaciona-se positivamente com mentira do cliente $(\rho=.633)$ e culpar do Cliente $(\rho=.641)$ e a solicitação de reflexão do terapeuta e o culpar do cliente $(\rho=.668)$.

Diferentemente do que tinha vivido em suas relações com seus pais e avós (Tabela 8), S4 passava a ter oportunidade de vivenciar relações consistentes com alguns educadores, estagiárias e psicoterapeuta. Por outro lado, como em toda unidade de internamento, S4 sofria pressão dos colegas internos e até mesmo de outros educadores que não acreditavam na possível recuperação a que visava o trabalho 
terapêutico. Ainda, muito teve que ser trabalhado no sentido de que S4 aprimorasse suas habilidades de leitura de ambiente e análise de contingências, pois algumas professoras da unidade agiam de forma inconsistente e super-protetora, confundindo a percepção do mesmo sobre confiança e recebimento de afeto. Por exemplo, ao invés de repreender o adolescente quando ele fazia alguma coisa que não estava de acordo com os combinados, estas professoras propunham uma nova chance em termos de um "voto de confiança" não consequenciando corretamente o comportamento inadequado do jovem. Percebia-se que após este tipo de comportamento das professoras, S4 ficava confuso e apresentava comportamentos inadequados em outros contextos, exigindo que as pessoas perdoassem seus erros em nome do afeto que diziam sentir por ele.

Tabela 8. Práticas educativas dos cuidadores de S4 avaliadas através do Inventário de Estilos Parentais.

\begin{tabular}{|c|c|c|c|c|c|c|c|c|}
\hline IEP S4 & 童 & 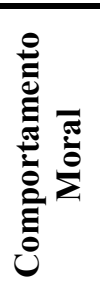 & 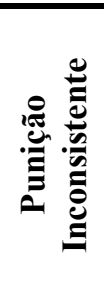 & 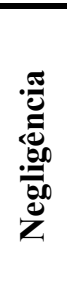 & 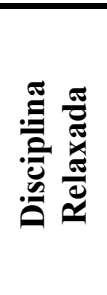 & 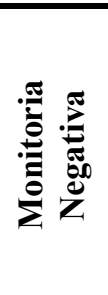 & 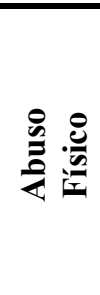 & IEP \\
\hline IEP Materno & 9 & 10 & 7 & 3 & 0 & 11 & 8 & -10 \\
\hline IEP Avó & 8 & 10 & 3 & 2 & 7 & 9 & 3 & -6 \\
\hline IEP Avô & 8 & 7 & 3 & 3 & 4 & 6 & 3 & -4 \\
\hline IEP Paterno & 1 & 2 & 5 & 3 & 0 & 3 & 10 & -18 \\
\hline
\end{tabular}

Além de todos os valores totais do IEP indicarem Estilos Parentais de Risco, em destaque na Tabela 8 encontram-se os valores das práticas educativas indicativos de risco. O pai não utilizava prática positiva de monitoria positiva e comportamento moral e fazia uso acentuado das práticas negativas de punição inconsistente e abuso físico. $\mathrm{O}$ avô apresentava práticas positivas satisfatórias que poderiam ter sido melhoradas através de procedimentos de orientação, porém apresentava acentuadas práticas negativas de disciplina relaxada, monitoria negativa e abuso físico. 
A Mãe tinha práticas positivas que também poderiam ser aprimoradas através de orientações, mas apresentava com proeminência as práticas negativas de punição inconsistente, negligência, monitoria negativa e abuso físico. A avó precisaria ter recebido treinamento e intervenção terapêutica para aprender a prática de monitoria positiva e interromper o uso de disciplina relaxada, monitoria negativa e abuso físico.

A falta de monitoria positiva e comportamento moral está relacionada aos seguintes comportamentos das crianças e dos adolescentes: insegurança e posterior associação a grupos desviantes com possível uso e abuso de substâncias ilícitas e álcool, desconfiança nos relacionamentos, falta de empatia, não reconhecimento das emoções e descontrole das mesmas, desrespeito às regras e normas sociais, desrespeito à autoridade, falta de valores e conduta imoral, egoísmo, falta de solidariedade e compaixão (Gomide, 2004).

A presença maciça de práticas negativas de negligência, punição inconsistente, disciplina relaxada, monitoria negativa e abuso físico estão relacionadas ao desenvolvimento dos seguintes comportamentos: mentira, agressividade, associação com grupo desviante e uso e abuso de drogas e álcool, insegurança, falta de empatia, desafio a regras e normas sociais, baixa auto-estima, baixo auto-conceito, baixo repertório de comportamentos pró-sociais e de comportamentos de ajuda ao próximo, falta de perspectiva de futuro e incapacidade de manter vínculos duradouros (Gomide, 2004).

Todos estes comportamentos citados pela falta das práticas positivas, bem como pelo excesso das negativas, faziam parte do repertório comportamental de S4, que encontrou nas ruas e nas drogas o conforto e aceitação que nunca tivera em casa. 
Foi muito interessante vivenciar junto ao jovem os momentos nos quais ele percebeu as limitações dos avós como seus cuidadores, compreendendo o contexto no qual viviam e o repertório que possuíam devido às próprias histórias de vida, bastante sofridas por sinal.

Significativo avanço foi feito no processo psicoterápico do adolescente quando soube-se que havia uma situação de abuso sexual de um adolescente interno com retardo mental severo (F 72.9) (DSM-IV-TR, 2002) e este adolescente que sofria os abusos contou que um de seus abusadores era S4. À parte das medidas administrativas e jurídicas (o adolescente com retardo mental não deveria estar naquela unidade) S4 confirmou o fato em psicoterapia e declarou não se sentir culpado pois o adolescente abusado era considerado um pilantra e ainda "fazia aquelas coisa porque gostava"(SIC). Quando foi informado de que o adolescente possuía um retardo e sendo assim idade mental equivalente a uma criança de no máximo seis anos, S4 ficou chocado, pois esta deveria ser a idade aproximada de sua irmã. Foi realizado então um processo de empatia com a vítima e S4 pela primeira vez em todo o processo viveu o sentimento de culpa, tendo inclusive comportamentos depressivos acentuados por um período de quinze dias.

Outro grande passo foi dado no trabalho com S4 quando ele recebeu o rato albino para cuidar como animal de estimação e também quando ele, em uma crise de agressividade, alcoolizado, matou o animal.

$\mathrm{S} 4$ relatava com riqueza de detalhes sua vida no campo, contato com animais e paisagens das quais gostava. Em outubro de 2005 resolveu-se em conjunto com a direção da unidade entregar-lhe um rato albino para cuidar. Várias normas foram criadas para este acontecimento, deixando claro os cuidados de higiene, alimentação e manejo que ele deveria ter com o animal e as restrições do que poderia fazer com ele, 
por exemplo, não poderia emprestá-lo para outros adolescentes, sob o risco de perdê-lo, não podia expô-lo ao sol, não podia banhá-lo, etc. A experiência foi significativa revelando a capacidade de S4 de cuidar do animal e de expressar afeto por ele, o que foi generalizado para outras relações.

Porém, meses depois, em janeiro de 2006, durante uma atividade externa S4 fugiu (durante estas atividades o rato ficava em uma caixa-gaiola improvisada, no alojamento do adolescente) e horas mais tarde ligou para a terapeuta, chorando e dizendo estar arrependido, confuso e dizendo que queria voltar para a unidade. A terapeuta, acompanhada por um educador e um motorista da unidade foram buscá-lo em uma praça no centro da cidade. S4 estava alcoolizado e chegando à unidade ficou irritado com a revista de rotina. Não bastasse isso tentou comunicar-se com outros adolescentes pela portinhola das celas e foi impedido, tendo que ser fisicamente contido. Quando entrou em seu alojamento, aos berros, xingando os educadores que o levavam, agarrou o rato que estava dentro da caixa em cima da cama e atirou-o no chão, matandoo. O seguinte bilhete foi escrito no dia seguinte.

\section{Desabafo sozinho...}

Des da primeira vez que eu sai lá do estágio e disse que tinha ido fazer um peão eu estava mentindo por que na realidade eu tinha ido buscar um basiado depois disso eu não me cigurei e queria fumar cada vez mais e ai eu estava enganando todos que queria me ajudar porque quando eu escrevi aquele termo de responsabilidade e todos assinaram isso significa que eu tenho que ficar de boa porque eu não tenho direito de reclamar por que eu tava com tudo na mão e jogei fora agora já era porque ninguem vai acreditar na minha palavra.

Eu não posso dar contra versão no que eu falei um dia que eu estava quase indo pra maior e lembro que falei que puchava meus três aqui mas não queria ir pra cadeia de maior só que eu não cumpri com a minha palavra que não ia fujir nem fazer nada de errado mas eu sei que errei e que não sou digno de ter a confiança da minha terapeuta.

Por exemplo o snyrf quanto tempo que eu cuidei dele era meu ermão e companheiro que eu não sei o que aconteceu só vi que ele estava no chão 
cheio de sangue ai eu chorei um montão mas ai já era tarde porque ele já tinha morrido. Posei só com uma manta e na sexta-feira eu pedi p/ conversar com a Dra: Giovana mas não foi possivel pra minha tristesa porque eu magoei algumas pessoas que só queria o meu bem só que eu vou ficar de boa mas eu jamais vou me perdoa por tudo que eu fiz na quinta-feira.

Hoje sabado 21.01.06

Esse foi um desabafo sozinho...

\section{S5: O SOLITÁRIO}

Talvez o único adolescente cujo histórico infracional não era superado pelo de dependência química. Ao contrário dos outros adolescentes, S5 não fazia parte de nenhum grupo, não respeitava as leis da cadeia e do crime, não utilizava o dinheiro de seus crimes para nada além de comprar e consumir drogas. Com mais de dezenove passagens pela polícia e sete internamentos (sendo três para tratamento da dependência química) S5 recebeu a medida socioeducativa de internamento na qual se encontrava durante este trabalho após ter assaltado um ônibus (de onde subtraiu dois reais!).

Foi internado em uma unidade de sua cidade natal, porém cometeu um homicídio, matando um de seus colegas de cela e foi transferido para a capital do estado. Durante a grande rebelião de 2004 ele era um dos meninos jurados de morte, porém conseguiu fugir. Permaneceu no alojamento chamado "seguro" até que foi transferido para esta unidade.

Seus pais eram separados e ele tinha pouquíssimo contato com o pai, que trabalhava há mais de vinte anos na mesma empresa. A mãe fazia constante consumo de álcool e os dois irmãos mais velhos de S5 passaram por internamentos na adolescência. 
$\mathrm{Na}$ época do atendimento, em 2005, o irmão mais velho estava preso em uma penitenciária estadual.

Usuário de crack, solventes e inalantes, S5 apresentava comportamento agressivo com outros internos, educadores e técnicos. Certa vez, a polícia foi chamada para conter um tumulto iniciado por ele, que tentara agredir um educador. Ele foi despido e ficou no pátio com cerca de doze policiais do batalhão de choque, que tinham inclusive cachorros na operação, enquanto seu alojamento era minimamente organizado e limpo para que pudesse retornar. Quando os policiais ordenaram que se levantasse para ser conduzido até o alojamento, S5 investiu contra os mesmos tentando desarmar um deles. Este fato serve para ilustrar a impulsividade do jovem, que depois chorava e dizia não saber porque fazia aquelas coisas.

Minha, infância
Minha infância foi até os 11 anos, quando tive a infância era muito mais feliz do
que eu sou hoje, se divertia muito, gostava muito de carrinho de rolemã e de
bolinha de gude hoje eu não gosto mais disso,
Eu soltava muito pipa era briguento brigar todos os dias na escola e muitas vezes
na rua também. Não gostava de estudar só ia para a escola para bagunçar depois
que fis 12 anos não quis mas nada, se envolvi com aqueles que diz que é amigo
mas não é nada. Já na minha infância eu já tinha esprementado maconha pelo
menos umas 4 vezes por semana eu uzava maconha escondido dos outros. Depois
parei de usar. E eu andava muito de skate também.
Coisa que eu não gostava era jogar bola e ir para escola mas hoje já é outra coisa
hoje eu estou aprendendo a dar valor.

A psicoterapia do jovem iniciou março de 2005 com o objetivo de ensinar S5 a controlar sua agressividade. Este objetivo foi atingido. O adolescente adequou-se à rotina da unidade, cessaram suas gritarias e ataques de fúria. Em agosto de 2005 o jovem iniciou atividades externas (que eram as últimas etapas antes do 
desinternamento) participando de um grupo de habilidades sociais. No segundo encontro, segundo relato dos educadores devido à pressão de um outro adolescente que constantemente o ameaçava, S5 fugiu do transporte no caminho de volta para a unidade.

O participante 5 (S5) passou por 13 sessões de psicoterapia, das quais 6 foram analisadas. A Figura 18 abaixo mostra na distribuição linear das sessões, quais analisadas.

\begin{tabular}{|l|l|l|l|l|l|l|l|l|l|l|l|l|l|}
\hline Sessões & 1 & 2 & 3 & 4 & 5 & 6 & 7 & 8 & 9 & 10 & 11 & 12 & 13 \\
\hline Analisadas & & & & & & & & & & & & & \\
\hline
\end{tabular}

Figura 18. Sessões de psicoterapia analisadas do participante S5.

Na Figura 19 é possível observar que o objetivo de aumentar a ocorrência de comportamentos adequados e diminuir os inadequados foi atingido. Porém a pressão negativa do grupo e a grave dependência química não foram adequadamente tratadas, o que pode explicar o abandono do tratamento através da fuga de S5.

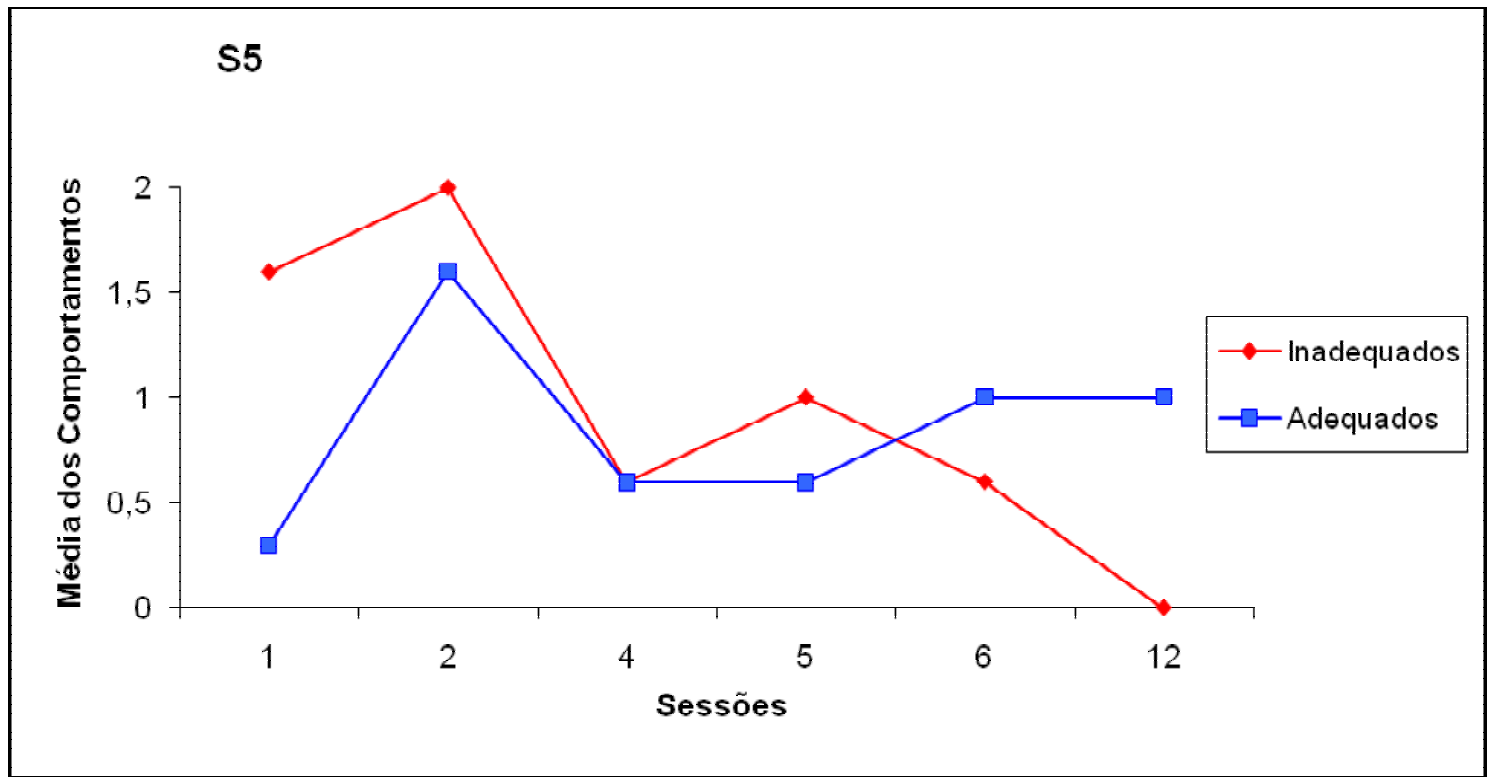

Figura 19. Média dos Comportamentos Inadequados e Adequados de S5 ao longo das sessões. 
Quanto aos comportamentos do terapeuta observa-se na Figura 20 a disparidade entre a média de solicitação de relatos (SRE) e os demais comportamentos do terapeuta. Excetuando-se os comportamentos de informação (INF), facilitação (FAC) e solicitação de reflexão (SRF), todas as demais médias são baixas $(n \leq 9)$ o que pode indicar a baixa interação entre terapeuta e cliente.

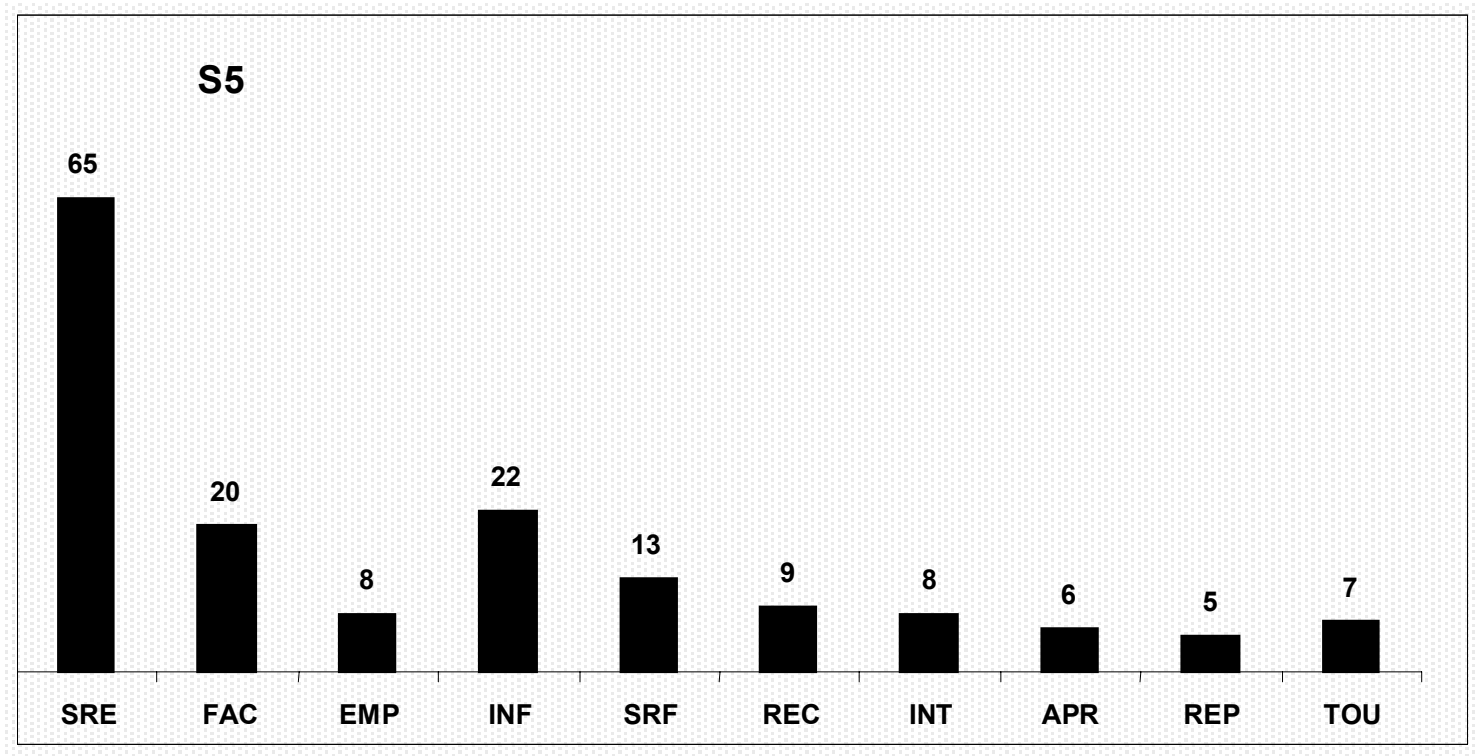

Figura 20. Média dos Comportamentos do Terapeuta por Sessão de S5.

Utilizando o teste não-paramétrico de Spearman foram encontradas correlações positivas entre alguns comportamentos do terapeuta e do cliente nas sessões de psicoterapia:

- Solicitação de relato do terapeuta e hostilidade do cliente $(\rho=.877)$

- Empatia do terapeuta e auto-revelação do cliente $(\rho=.840)$

- Informação do terapeuta e hostilidade do cliente $(\rho=.926)$

- Reprovação do terapeuta e hostilidade do cliente $(\rho=.906)$

Também foi encontrada a seguinte correlação negativa:

- Recomendação do terapeuta e auto-revelação do cliente $(\rho=-.828)$

Foi encontrada correlação positiva, indicando co-ocorrência entre três tipos de comportamento e a hostilidade do cliente, solicitação de relato, informação e 
reprovação do terapeuta. Torna-se possível supor que estes comportamentos do terapeuta ocorressem tanto como antecedentes quanto como conseqüentes ao comportamento de hostilidade. Como antecedentes teria que se compreender a história de vida do adolescente e a passagem do mesmo por pelo menos uma dúzia de trabalhos ditos terapêuticos e que de fato nunca apresentaram resultados. S5 tinha ampla experiência com psicólogos e assistentes sociais, não gostava de responder perguntas e preferia que seus prontuários fossem lidos para que ele não precisasse falar tudo de novo. Da mesma forma, mostrava-se pouco paciente ao receber informações, principalmente sobre o funcionamento da terapia, regras da unidade, combinados, informações sobre dependência química (este sim, certamente seu maior problema).

Porém não seria possível que a terapeuta deixasse de apontar estas percepções frente à hostilidade de S5, portanto, comportamentos hostis poderiam ter como conseqüentes solicitações de relato da terapeuta acerca dos sentimentos do cliente, reprovação e até mesmo informações que mudassem o foco do assunto evitando a escalada da hostilidade (importante estratégia face à agressividade deste cliente).

Este adolescente sentia-se incompreendido por profissionais da unidade, que já não acreditavam mais na sua recuperação, e também pelos demais adolescentes. A terapeuta procurava mostrar empatia com os sentimentos de rejeição do jovem, o que se reflete na relação estatística significativamente positiva encontrada entre a empatia da terapeuta e o comportamento adequado do cliente de auto-revelação. Neste caso pode-se dizer que empatia antecedia e consequenciava comportamentos de auto-revelação do cliente. 
Tabela 9. Práticas educativas dos cuidadores de S5 avaliadas através do Inventário de Estilos Parentais.

\begin{tabular}{|c|c|c|c|c|c|c|c|c|}
\hline IEP S5 & 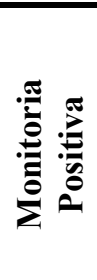 & 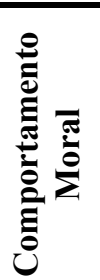 & 总 & 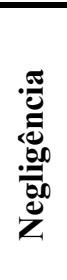 & 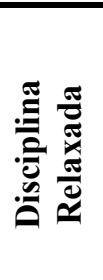 & 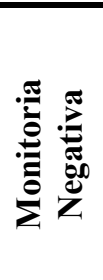 & 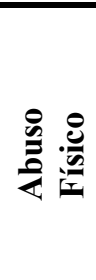 & IEP \\
\hline IEP Materno & 10 & 10 & 7 & 3 & 3 & 7 & 5 & -5 \\
\hline IEP Paterno & 11 & 12 & 3 & 4 & 6 & 7 & 0 & 3 \\
\hline
\end{tabular}

O resultado total do IEP materno de S5 aponta para o Estilo Parental de Risco, e o do pai para Estilo Parental Regular, abaixo da média (Tabela 9). É preciso ressaltar que apesar da melhor avaliação das práticas educativas do pai de S5 em detrimento às da mãe não influenciou de forma significativa os comportamento do jovem, pois seu contato com o pai era mínimo e não se sabe até que ponto esta percepção do jovem não era distorcida. Sendo assim, serão consideradas apenas as práticas maternas para fins de análise e discussão.

A mãe fazia uso das práticas negativas de risco de punição inconsistente, negligência, monitoria negativa e abuso físico. É fato que ela mesma também era usuária de álcool e drogas, alternando períodos de abuso de substâncias com períodos de abstinência e devoção religiosa fanática. Então além das práticas educativas que proporcionaram a S5 uma deterioração de sua auto-imagem e autoconfiança, sua mãe oferecia modelo de comportamento desviante com o uso de drogas. Somando estes fatores entende-se claramente a dependência química grave de S5 que o tinha feito desenvolver repertório infrator principalmente de roubar e enganar, pois era assim que mantinha seu vício.

As cartas de S5 para a mãe deixavam claras as dificuldades que o jovem tinha de perceber a relação entre os comportamentos da mãe e sua história de vida, repleta de abuso e negligência. 
De: seu filho S5 Para: minha mãezinha

Mãe/ Espero que quando esta carta chegar em suas mãos, chegue na mais perfeita paz de Deus.

Mãe como que esta com vocêis ai em casa espero que esteja bem, porque eu não estou bem porque estou longe de vocêis, mas se Deus quiser logo estou do lado de vocêis.

Eu fis uma loucura la nointernamento eu nem pensei na hora que eu fis aquilo ele tinha falado que veio me matar e ai foi o alcontrario. mas eu tenho fé em Deus que vou sair logo eu não guento mais ficar longe de vocêis, e a C como que esta fala que mando beijos e abraços e o mesmo para o R e a A, fala pra eles escreve para mim estou com muita saudades.

Mãe te amo $D^{+}$

\section{S6: O REJEITADO}

S6 foi admitido na unidade de internamento em março de 2006, com dezoito anos e setes meses de idade, devido às infrações de homicídio e tentativa de homicídio. Antes de ser preso residia com a mãe e um dos irmãos. Tem outros irmãos mas não sabe exatamente quantos. Até onde sabe sua mãe teve mais ou menos seis filhos, as primeiras eram gêmeas, mas por problemas de saúde vieram a falecer dias depois do parto; o terceiro filho vive com a mãe, o quarto filho, que tinha o mesmo nome que S6, foi entregue para adoção. O quinto irmão foi adotado pela tia materna, e o sexto é S6. Logo que nasceu sua avó materna o escondeu, pois, sua mãe também o entregaria para adoção. Seu pai já é falecido e o jovem não o conheceu. Foi criado de fato pela avó materna que faleceu em 2003. A mãe tem problemas de saúde desde que ele nasceu, fora atropelada alguns anos antes do internamento do filho e tem seqüelas físicas e motoras, além disso é alcoolista. Conviveu mais com a avó, sua casa ficava nos fundos da casa dela. A mãe não costumava brincar nem sentar para conversar, pois tem problemas com bebida desde sua mocidade. Ele mesmo concluiu que esta situação 
o distanciara da mãe e o aproximara da avó. S6 relata que já na creche era "judiado", que batiam nele e ele se acostumou; foi expulso de escolas três vezes durante o ciclo básico do ensino fundamental. Era muito indisciplinado na escola e parou de estudar na época em que começou a usar maconha, aos 12 anos. Como dava muito trabalho a mãe solicitou ao conselho tutelar que ele fosse internado em um colégio, do qual ele constantemente fugia.

A mãe xingava e batia muito em S6. Apanhava de mangueira, cinta, chicote e o que mais estivesse à disposição para ser usado como objeto de espancamento. A avó era quem interrompia as surras quando estava por perto. Dizia que apanhava por que fazia coisas erradas "acho que eu era um demoninho". Chegava a apanhar duas vezes por dia, já estava acostumado, a mãe batia por qualquer coisa. S6 chorava e esperava passar a dor. A única vez que sentiu vergonha de apanhar foi quando a mãe foi buscá-lo na casa de vizinhos onde passou a noite usando drogas pela primeira vez; desta vez ficou muito machucado e fugiu.

O seu primeiro ato infracional foi o roubo de um toca $\mathrm{CD}$, para comprar Crack, tinha aproximadamente 14 anos e estava com outro adolescente. Ia armado muitas vezes com faca, até adquirir uma arma. Não sentia culpa e fazia para comprar droga. O próprio adolescente sinalizava que esta vida começou logo que a avó faleceu. Utilizava diariamente crack, maconha e solventes.

Não tinha sido detido até cometer um latrocínio. Cumpriu a medida socieducativa de internamento em sua cidade natal por seis meses e então foi transferido para uma casa de semi-liberdade, onde permaneceu por uma semana e depois fugiu. Passado mais de um ano em liberdade cometendo vários atos infracionais, S6 envolveuse em uma briga de gangues e cometeu um homicídio e tentou outro. Permaneceu escondido por dois meses até que foi apreendido durante um assalto. A nova medida de 
internação proferida dizia que ele deveria ser internado em outra cidade. Sendo assim foi transferido, porém após poucos meses nova transferência foi solicitada pois S6 participou de uma agressão a educadores sociais e constantemente ameaçava outros adolescentes. Então o adolescente chegou na unidade de internamento onde realizou-se este trabalho. Permaneceu internado até fevereiro de 2007 quando foi solicitado seu desinternamento.

O participante 6 (S6) passou por 10 sessões de psicoterapia, das quais 6 foram analisadas.

A Figura 21 abaixo mostra na distribuição linear das sessões, quais as analisadas.

\begin{tabular}{|l|l|l|l|l|l|l|l|l|l|l|}
\hline Sessões & 1 & 2 & 3 & 4 & 5 & 6 & 7 & 8 & 9 & 10 \\
\hline Analisadas & & & & & & & & & & \\
\hline
\end{tabular}

Figura 21. Sessões de psicoterapia analisadas do participante S6.

O processo terapêutico de S6 foi marcado pela coerência da diminuição de comportamentos inadequados concomitante ao aumento de comportamentos adequados, como se observa na Figura 22.

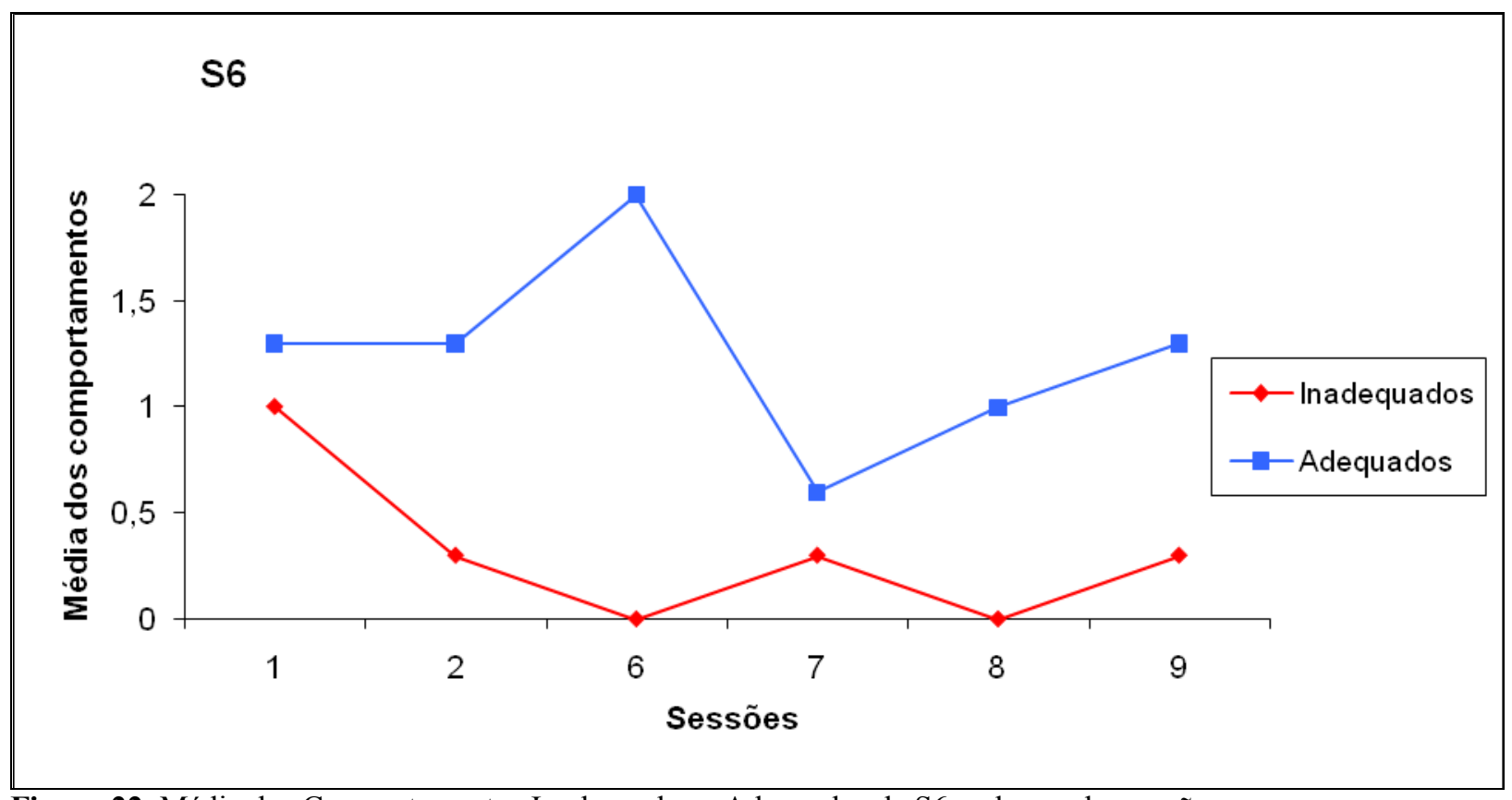

Figura 22. Média dos Comportamentos Inadequados e Adequados de S6 ao longo das sessões. 
$\mathrm{Na}$ Figura 23 observa-se novamente as baixas médias dos comportamentos do terapeuta de reprovação (REP), aprovação (APR) e recomendação (REC). A alta média de comportamento do terapeuta de informação (INF) pode estar relacionada ao fato de que muito se discutiu o alcoolismo e seus efeitos. O adolescente sabia pouco sobre o problema e tinha grande interesse, pois além de ser acometido pelo problema, também o era sua mãe.

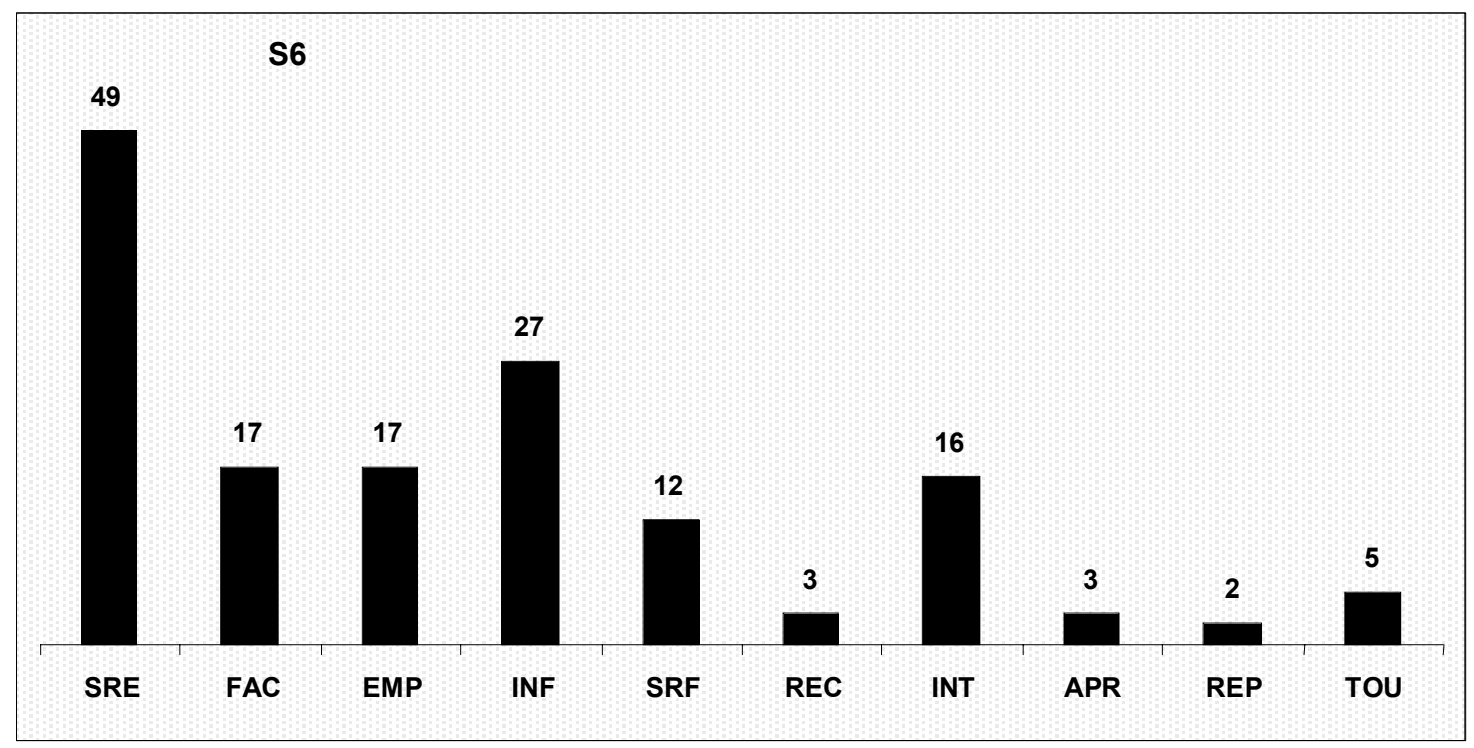

Figura 23. Média dos comportamentos do terapeuta por sessão Caso S6

Utilizando o teste não-paramétrico de Spearman foram encontradas correlações positivas entre alguns comportamentos do terapeuta e do cliente nas sessões de psicoterapia:

- Recomendação do terapeuta e mentira do cliente $(\rho=.980)$

- Interpretação do terapeuta e mentira do cliente $(\rho=.828)$

- Interpretação do terapeuta e auto-revelação do cliente $(\rho=.828)$ 
- Aprovação do cliente e hostilidade do cliente $(\rho=.905)$

Estas correlações indicam que os comportamentos variavam conjuntamente, mas não indicam uma única direção no sentido de causa. Sendo assim a recomendação do terapeuta pode ter ocorrido em função das mentiras do cliente, mas também se poderia dizer o contrário, ou seja, não seguindo as recomendações o cliente mentia para o terapeuta, ao invés de admitir não ter seguido a recomendação.

Quanto às interpretações do terapeuta, importante estratégia de trabalho dos analistas do comportamento, pois proporciona ao cliente identificar as relações existentes entre contingências presentes nas situações, é possível observar que se correlacionaram positivamente com comportamentos de mentir do cliente, mas também com comportamentos de auto-revelação do mesmo cliente. Várias hipóteses podem ser levantadas nestes casos. É possível que interpretações seguissem comportamentos de mentira do cliente identificados pela terapeuta, como no seguinte exemplo: "S3, quando você mente para mim não posso ajudá-lo, pois sem saber de fato como as coisas aconteceram nada do que eu fale será útil. Mentira não constrói confiança. Enquanto você não confiar, as mentiras continuarão, e eu continuarei sem poder ajudar.”

Outra possibilidade é que S6 não admitisse algumas análises feitas pela terapeuta, por falta de repertório, ou de vínculo, etc, mas o fato é que caso isso ocorresse ele poderia consequenciar as interpretações negando-as fazendo para isso uso da mentira, como no exemplo, "S6 você afasta as pessoas com a sua agressividade e desta forma não faz vínculos. Não fazendo vínculos não corre o risco de perdê-los ou de se sentir abandonado novamente..." ao que S6 responde "Nada disso não. Não tenho problema em ser sozinho. Esse meu jeito brabo é de família, assim ninguém manga de mim." 
Quanto à correlação positiva encontrada entre interpretação do terapeuta e auto-revelação do cliente, parece ser algo que acontece em um estágio do processo terapêutico no qual o cliente participava mais ativamente sendo beneficiado e facilitando a ocorrência de interpretações do terapeuta. Desta forma ambos comportamentos podem se alternar, ora servindo um ao outro com estímulo discriminativo, ora como estímulo reforçador.

A forte correlação encontrada entre aprovação do terapeuta e hostilidade remete imediatamente à capacidade de aceitação necessária ao profissional neste tipo de processo terapêutico. Sendo assim é preciso citar que a dificuldade dos infratores em lidar com situações para as quais não possuem repertório, e a aceitação é uma delas, pode ser expressa através da hostilidade. Porém, no caso de S6 a terapeuta levou em consideração os fatos relacionados à saúde precária da mãe do jovem e pôde através da aprovação consequenciar a hostilidade como uma manifestação de raiva $\mathrm{e}$ desapontamento pertinentes à situação.

Conforme se observa na Tabela 10 as práticas educativas da mãe de S6 eram principalmente negativas. O índice total do IEP da mãe indicava Estilo Parental de Risco e o da avó indicava Estilo Parental Regular, abaixo da média. Durante o processo terapêutico S6 compreendeu o comprometimento do alcoolismo da mãe na forma como ela o criou. Ele passou então a cobrar da mãe que se tratasse, mas a saúde dela vinha piorando acentuadamente. A falta de cuidado que a mãe tinha com ela mesma passou a gerar sentimentos de raiva e preocupação em S6, que apareciam como hostilidade nas interações do adolescente. Ao mesmo tempo isso proporcionou situações nas quais S6 falou de seu amor pela mãe (não correspondido por ela), de como ele se arrependia por não tê-la ajudado antes porque também estava envolvido com drogas e álcool, e de 
como pretendia modificar seus comportamentos para poder ajudar a si mesmo e também a mãe doente.

É típico dos infratores desconsiderar os abusos e a negligência materna ao mesmo tempo que se consideram culpados pela "infelicidade" da genitora e pelos comportamentos de bater, espancar e abandonar, pois justificam que mereciam ser tratados assim. Isto também acontecia com S6 apesar de ter sofrido a falta de monitoria positiva e ausência de comportamento moral da mãe, e além de ter vivenciado a punição inconsistente, negligência, monitoria positiva e abuso físico por parte de sua mãe.

Tabela 10. Práticas educativas dos cuidadores de S6 avaliadas através do Inventário de Estilos Parentais.

\begin{tabular}{|c|c|c|c|c|c|c|c|c|}
\hline IEP S6 & 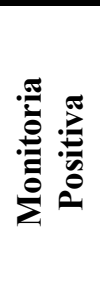 & 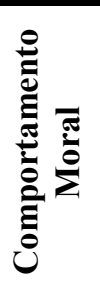 & 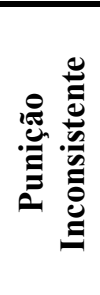 & 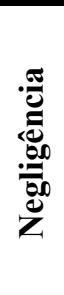 & 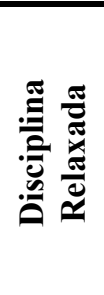 & 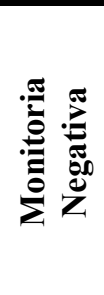 & $\begin{array}{l}\frac{8}{0} \\
\frac{0}{2} \\
\frac{0}{4}\end{array}$ & IEP \\
\hline IEP Materno & 6 & 1 & 3 & 4 & 1 & 7 & 11 & -19 \\
\hline IEP Avó & 11 & 10 & 2 & 2 & 2 & 5 & 0 & 10 \\
\hline
\end{tabular}

A avó de S6 fez uma tentativa de cuidar do neto rejeitado pela mãe e protegê-lo do modelo de abuso de álcool e drogas da mãe, além das surras que ela, a mãe, aplicava nele quando chegava alcoolizada em casa. Porém, esta avó faleceu precocemente, fato que fortaleceu a sensação de inadequação e de abandono de S6.

Estes aspectos da história de vida do adolescente foram importantes assuntos discutidos em psicoterapia para que ele pudesse compreender o papel que o abandono e a rejeição tinham em seus comportamentos. 


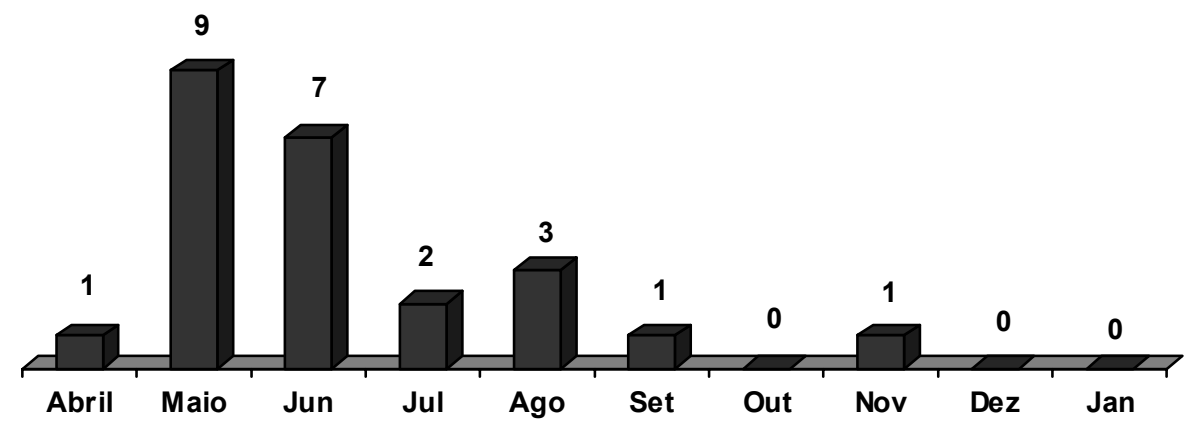

Figura 24. Avaliação Diária de Comportamentos Inadequados de S6.

A Figura 24 demonstra os resultados das avaliações diárias de comportamentos inadequados que era realizada na unidade de internamento. A diminuição de comportamentos inadequados na rotina de S6 pode demonstrar a generalização de mudanças ocorridas também em ambiente terapêutico.

\section{S7: O RECLAMÃO}

Este adolescente tinha quinze anos no início de sua psicoterapia em 2005. Foi preso no interior do estado em janeiro de 2005 devido a um homicídio. Esta já era sua segunda apreensão por homicídio. Foi transferido para esta unidade em setembro de 2005 devido às inúmeras situações de indisciplina, agressão e rebeldia na unidade de internamento na qual se encontrava. Fugiu de atividade externa em fevereiro de 2006 e foi reaprendido em abril do mesmo ano.

Iniciou uso de drogas aos onze anos (cola de sapateiro, tinner, crack, cocaína, tabaco e álcool). Relatou ter uma infância tranqüila até o falecimento do pai, no ano de 1993, quando ele tinha apenas três anos. O pai era traficante e morreu vítima das complicações advindas da AIDS. A mãe, também portadora do vírus, assumiu as 
atividades ilícitas do marido, sendo presa por tráfico internacional de drogas seis anos mais tarde. Quando presa, em 1994 teve mais uma filha, que com ela permaneceu até os três anos de idade. Permaneceu presa até o ano de 2001 quando teve sérias complicações de saúde devido à AIDS e ficou internada por mais de seis meses. Em 2005 passou vários dias em coma, vindo a falecer naquele mesmo ano. S7 tinha um irmão mais velho, do primeiro casamento da mãe, e mais quatro biológicos. O mais velho nunca residiu com eles e não possuía histórico infracional. O biológico mais velho estava preso. A irmã mais velha é adotada, dependente química, não estudava e nem trabalha. As duas irmãs mais novas são portadoras do HIV e moram cada uma com uma tia.

No período em que a mãe esteve presa S7 e os irmãos residiram com uma tia que os maltratava. $\mathrm{O}$ adolescente tinha péssimas lembranças desta época e considerava que muitos de seus problemas eram frutos desse tempo. Contou que passava fome, frio, sentia solidão, tristeza e era espancado e ridicularizado. Na escola era temido por professores e outros alunos; foi expulso várias vezes.

O participante 7 (S7) iniciou a terapia em outubro de 2005 e passou por 28 sessões de psicoterapia, das quais 10 foram analisadas. A Figura 25 abaixo mostra na distribuição linear das sessões, quais as analisadas.

\begin{tabular}{|c|c|c|c|c|c|c|c|c|c|c|c|c|c|c|c|c|c|c|c|c|c|c|c|}
\hline Sessões & 1 & 2 & 3 & 4 & 5 & 6 & 7 & 8 & 9 & 10 & 11 & 12 & 13 & 14 & 15 & 16 & 17 & 18 & 19 & 20 & 21 & 22 & 23 \\
\hline Analisadas & & & & & & & & & & & & & & & & & & & & & & & \\
\hline & 24 & 25 & 26 & 27 & 28 & & & & & & & & & & & & & & & & & & \\
\hline
\end{tabular}

Figura 25. Sessões de psicoterapia analisadas do participante S7.

Em fevereiro de 2005 (após a sessão 13 que foi no dia 8 de fevereiro) o adolescente S7 empreendeu fuga durante a realização de uma atividade externa de profissionalização. Alguns dias depois telefonou para a psicoterapeuta dizendo que sabia que a decepcionou, mas que estava insuportável viver preso e que não tinha 
agüentado a "tentação da liberdade". Solicitou que a psicoterapeuta continuasse a terapia dele, ao que ela respondeu que não seria possível porque ele estava foragido da justiça. Nos meses em que passou evadido da unidade o adolescente telefonava constantemente para a psicoterapeuta e assegurava que estava bem, que não estava "aprontando muito" e que um dia voltaria para cumprir o que devia pra justiça. Nestes telefonemas dizia que gostava muito da psicoterapeuta por ela ser a única pessoa que se preocupava de verdade com ele.

No início de junho do mesmo ano S7 estava com dois adultos em um veículo com a placa adulterada e foi apreendido. Já na delegacia o adolescente, quando estava sendo liberado horas depois, solicitou a presença da delegada e contou ser interno evadido da unidade de internamento. A delegada estranhando o fato telefonou para a direção para confirmar a informação. S7 permaneceu dois dias na Delegacia do Adolescente e então retornou para a unidade.

Na retomada da psicoterapia, no dia 30 de junho (sessão 14), a sessão teve como objetivo além de reiniciar o contato, relembrar os combinados da terapia, regras, funcionamento, etc. Quando entrou na sala, S7 sorriu e expressou estar alegre. O adolescente solicitou que a psicoterapeuta ouvisse-o no relato de coisas negativas sobre a "cadeia", comportando-se como um porta-voz dos demais jovens. Foi interrompido e lembrado pela mesma de que o papel do psicólogo não era este. O adolescente falou sobre lembranças da mãe, contou que estava namorando uma moça no período em que estava foragido e disse que não havia matado ninguém naquele período, atribuindo isto à terapia. Conversaram também sobre músicas e as emoções que são sentidas enquanto as escutamos. 


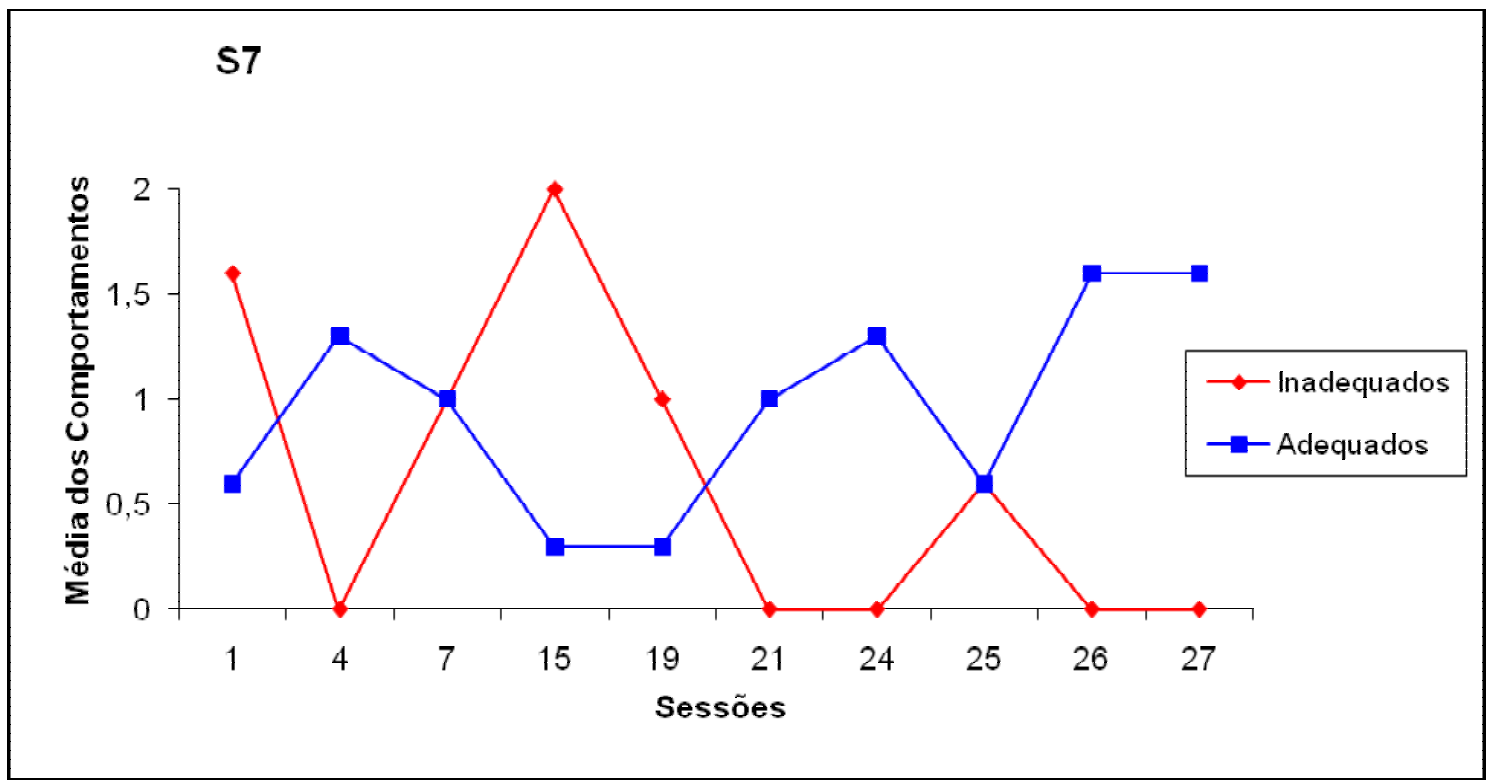

Figura 26. Média dos Comportamentos Inadequados e Adequados de S7 ao longo das sessões.

No decorrer do processo psicoterápico de S7 é possível notar oscilações bruscas no aumento e diminuição da ocorrência de comportamentos inadequados (Figura 26). Os comportamentos adequados eram mais presentes nas próprias sessões do que fora delas e talvez seja por isso que pouco alcançou avaliação máxima $(\mathrm{N}=2)$ de ocorrência. Ou seja, S7 desenvolveu repertório de comportamentos adequados na interação com a terapeuta, mas não chegou a generalizá-los da maneira esperada em outros ambientes.

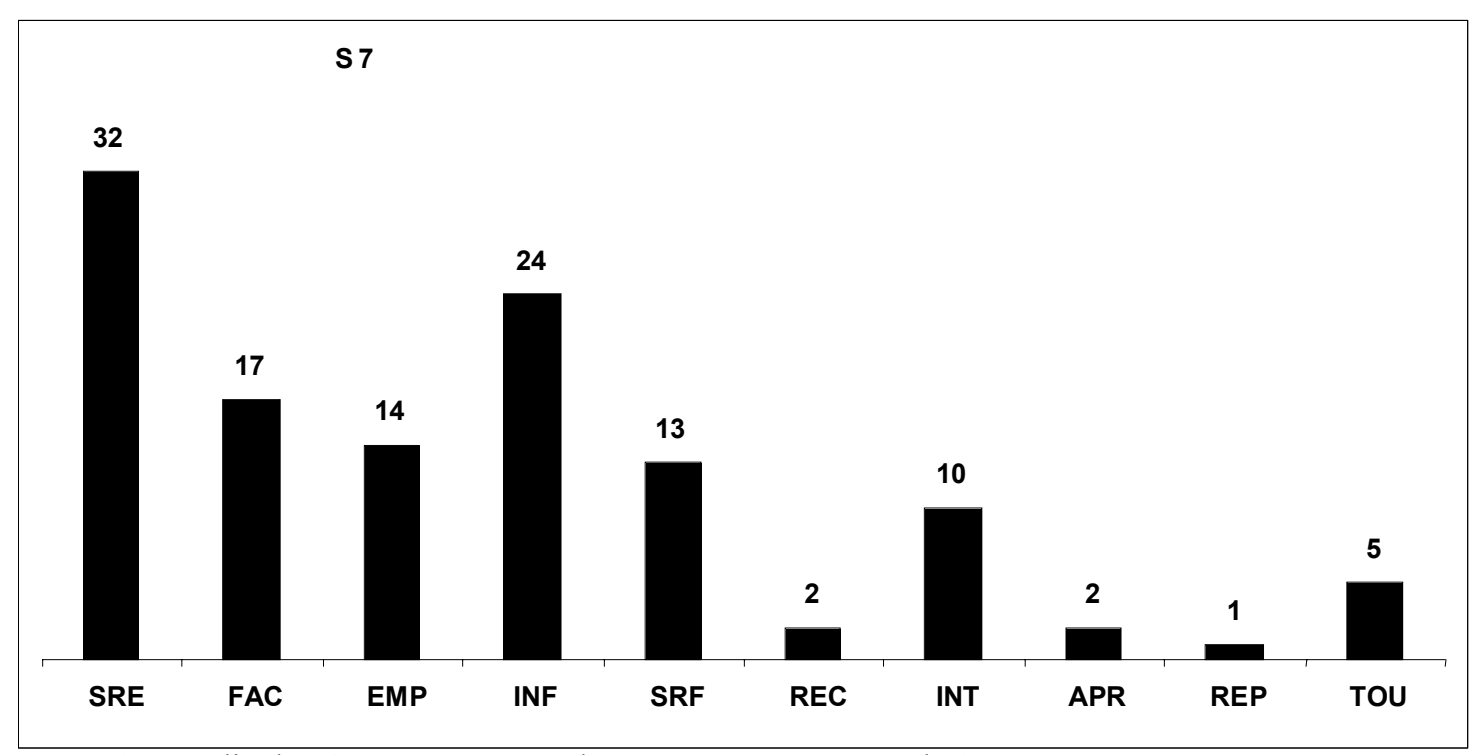

Figura 27. Média dos Comportamentos do Terapeuta por sessão de S7. 
Sobre os comportamentos da terapeuta neste processo (Figura 27) é possível verificar que mais uma vez a maior média é a de solicitação de relatos (SRE) e as mais baixas são as de reprovação (REP), aprovação (APR) e recomendação (REC). Médias elevadas, indicando considerável ocorrência, também foram encontradas para informação (INF), facilitação (FAC), empatia (EMP), solicitação de reflexão (SRF) e interpretação (INT).

Utilizando o teste não-paramétrico de Spearman foram encontradas correlações positivas entre alguns comportamentos do terapeuta e do cliente nas sessões de psicoterapia:

- Facilitação do terapeuta e hostilidade do Cliente $(\rho=.758)$

- Empatia do terapeuta e hostilidade do Cliente $(\rho=.820)$

- Solicitação de reflexão terapeuta e culpar do cliente $(\rho=.686)$

Também foram encontradas as seguintes correlações negativas:

- Facilitação do terapeuta e sentimento positivo do Cliente $(\rho=-.891)$

- Empatia do terapeuta e sentimento positivo do cliente $(\rho=-.847)$

- Solicitação de reflexão do terapeuta e autorevelação do cliente $(\rho=-.664)$

- Interpretação do terapeuta e sentimento positivo do cliente $(\rho=-.717)$

- Outras verbalizações do terapeuta e arrependimento $(\rho=-.869)$

Neste caso a correlação encontrada entre empatia do terapeuta e hostilidade do cliente parece indicar claramente a importância que teve neste processo a terapeuta compreender as reações hostis do cliente S7. A despeito de todas as manifestações hostis ela continuava manifestando compreensão de que não havia por parte do cliente possibilidade de agir de outra maneira por falta de repertório. Esta falta de repertório explicava-se por vários fatos da história de vida do jovem. Neste caso 
parece que a empatia não era um estímulo antecedente para a hostilidade do cliente, pois este comportamento dele ocorria indiferenciadamente, com alta freqüência no início da psicoterapia. Mais tarde foi possível observar mudanças, mas a hostilidade persistiu por muito tempo em outros ambientes que não a terapia.

O mesmo pode se dizer para a correlação positiva entre facilitação do terapeuta e hostilidade do cliente e a correlação negativa entre facilitação do terapeuta e sentimento positivo do cliente. O cliente possuía repertório de interação limitado, desta maneira era preciso aproveitar o repertório do qual ele dispunha para estabelecer uma comunicação que proporcionasse quaisquer possibilidades de obtenção de dados e estabelecimento de relação terapêutica. Sendo assim, comportamentos do terapeuta que esperava-se poderiam anteceder respostas adequadas do cliente não possuíam esta função, principalmente no início do processo. Não adiantava quão facilitadora ou empática a terapeuta era, as respostas inadequadas eram emitidas e as adequadas não.

Justificada também pela falta de comportamentos pró-sociais básicos do cliente, a correlação positiva encontrada entre a solicitação de reflexão do terapeuta e o culpar do cliente parece adequada ao caso. O repertório de resolução de problemas de S7 era muito baixo, as respostas iniciais a qualquer situação de conflito ou dificuldade eram de culpar o outro, fossem estas situações propostas para reflexão pela terapeuta ou fosse a reflexão solicitada após a emissão do comportamento de narrar um fato culpando outrem. Seguindo a mesma linha de raciocínio é possível compreender a correlação negativa encontrada entre a solicitação de reflexão do terapeuta e a autorevelação do cliente $(\rho=-.664)$.

O mesmo tipo de justificativa teria a correlação negativa encontrada entre o comportamento de empatia do terapeuta e sentimento positivo do cliente. 
Enquanto seria de se esperar que ocorressem conjuntamente, não parece ter sido isto que aconteceu $(\rho=-.847)$.

Sobre as práticas educativas das cuidadoras de S7 há que se fazer algumas considerações acerca do contexto real e de como o jovem o percebia. Sabe-se pelos relatos da história de vida de S7 que sua mãe fora sempre associada ao tráfico de drogas, tinha uma grave doença, era viúva e perdera o marido devido à mesma doença que possuía e passou muitos anos presa. Portanto, os índices de práticas educativas tais como avaliados pelo adolescente, após a morte da mãe, devem ser considerados sob perspectiva de uma possível idealização ou super-valorização de uma imagem de mãe construída pelo jovem, que há muitos anos não convivia com ela, ou seja, ele não respondeu o instrumento com base nas contingências vivenciadas. Resumindo: não parece possível que uma senhora com tal envolvimento criminal, sob o stress de uma doença grave e encarcerada tivesse um "estilo parental ótimo, com presença marcante das práticas parentais positivas e ausência das práticas negativas"(Gomide, 2006) de acordo com a pontuação total obtida no IEP (Tabela 11).

Tabela 11. Práticas educativas dos cuidadores de S7 avaliadas através do Inventário de Estilos Parentais.

\begin{tabular}{|c|c|c|c|c|c|c|c|c|}
\hline IEP S7 & 童 & 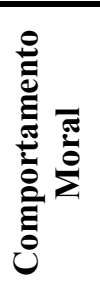 & 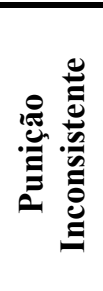 & 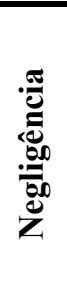 & 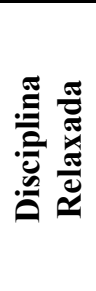 & 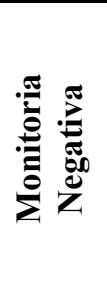 & 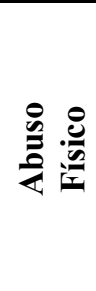 & IEP \\
\hline IEP Materno & 10 & 5 & 0 & 2 & 0 & 6 & 0 & 12 \\
\hline IEP Tia & 2 & 3 & 6 & 8 & 10 & 9 & 9 & -37 \\
\hline
\end{tabular}

As práticas educativas da tia que o criou por vários anos parecem através dos resultados do IEP se relacionar mais coerentemente o comportamento infrator de S7. Destaca-se a falta de monitoria positiva e comportamento moral, que se relacionam à falta de cuidados básicos, atenção positiva e modelos e valores morais ofertados (Tabela 11). Já a presença de risco de todas as práticas educativas negativas explicam 
vários comportamentos do adolescente, dentre os quais: mentira, agressividade, associação com grupo desviante e uso e abuso de drogas e álcool, insegurança, falta de empatia, desafio a regras e normas sociais, baixa auto-estima, baixo auto-conceito, baixo repertório de comportamentos pró-sociais e de comportamentos de ajuda ao próximo, falta de perspectiva de futuro e incapacidade de manter vínculos duradouros (Gomide, 2004).

Os registros diários de comportamentos inadequados de S7 na unidade (Figura 28) denotam claramente a presença maciça de comportamentos inadequados do adolescente no período em que retornou para a unidade após sua fuga no mês de fevereiro.

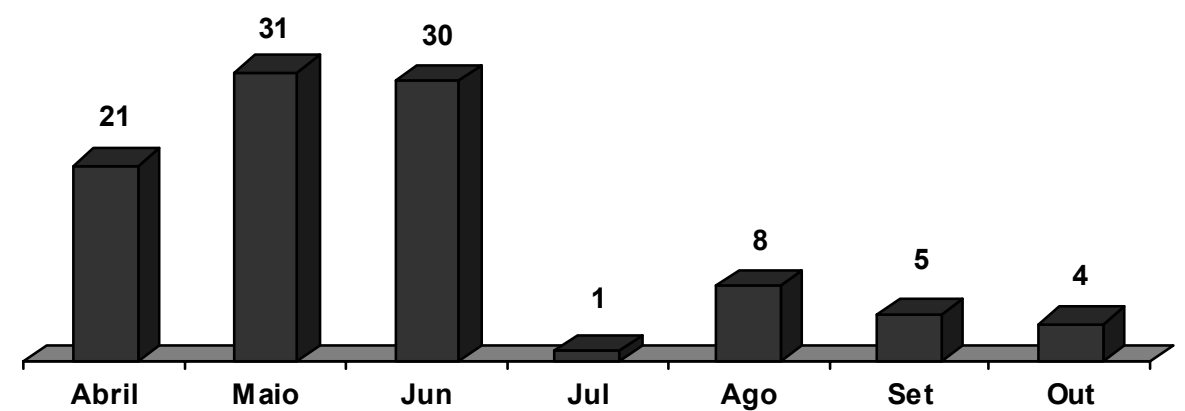

Figura 28. Registros Diários de Comportamentos Inadequados de S7.

Apesar da diminuição dos inadequados a partir do mês de Julho (Figura 28), ainda assim estes ocorriam nas atividades diárias da unidade. Mais uma vez se ressalta que estes comportamentos passaram a ter baixa ocorrência, praticamente não ocorrendo, dentro da sessão de psicoterapia, mas mantinham-se fora dela. 


\section{S8: O ATOR}

Nascido em 1987 este adolescente recebeu altas pontuações na Escala Hare PCL-R (Hare, 1991) indicando a presença de transtorno anti-social de personalidade, com características psicopáticas, de acordo com a terminologia forense. Em sua documentação observava-se o fato do pai não ser declarado, porém o adolescente relatou ter conhecido o mesmo em torno dos quatorze anos e ter se decepcionado com o encontro. A mãe foi expulsa da casa de seus pais assim que soube estar grávida. Com poucas semanas de vida foi entregue pela mãe aos cuidados de uma senhora até que os avós maternos, ao tomarem conhecimento do fato, levaram S8 para casa, lá ele permaneceu até um ano de idade quando a irmã mais velha da mãe assumiu seus cuidados.

Foi então criado pela tia até aproximadamente os seis anos de idade, quando sua mãe começou a participar de sua criação. A mãe tinha uma vida desregrada e sexualmente promíscua, expondo seu filho a situações traumáticas e de risco. S8 passou a conviver alternadamente com a mãe e com a tia materna, mas nas entrevistas referia-se à tia materna como mãe.

No inicio da adolescência de S8 a família da tia materna da qual fazia parte, mudou-se de uma cidade, para outra, para onde também mudou-se sua mãe, porém continuaram residindo em casas separadas. Neste período o adolescente começou a apresentar problemas de comportamento na escola, o que resultou em uma expulsão. A tia voltou para a cidade natal e S8 permaneceu com a mãe. Neste ínterim a mãe do jovem conheceu seu futuro companheiro e pai do irmão de S8. Meses depois, a nova família mudou-se para a cidade de origem da família de S8. Naquele período, anterior à nova mudança de cidades, o adolescente teve seu primeiro e único contato com o pai 
biológico. Segundo relato do jovem o pai bebia todos os dias "mas não ficava bêbado de cair"(SIC) e tiveram um contato frio e distante.

A convivência com a mãe não era harmônica, S8 continuava tendo problemas de indisciplina na escola e exigia da mãe bens materiais que não estavam ao alcance da família. Ela contava que ele, o filho, nunca demonstrara respeito por ela. Em agosto de 2004 depois de uma briga com o padrasto devido a um cheque que S8 havia roubado dele, o adolescente saiu de casa por algumas horas e retornou com uma pistola. Mandou a mãe ficar trancada no banheiro com o irmão pequeno ameaçando-a com a arma. Encontrou o padrasto deitado na rede e disparou vários tiros matando-o imediatamente. Fugiu do local e foi apreendido três dias depois. Em novembro foi transferido da unidade de internamento onde se encontrava por problemas disciplinares. Na nova unidade, em dezembro do mesmo ano, foi um dos líderes de uma rebelião. Como já vinha sendo avaliado por um centro de atendimento psicossocial, e a conclusão do psiquiatra de que o jovem apresentava distúrbio de comportamento grave, personalidade instável e impulsividade, foi solicitado tratamento adequado e avaliação em unidade de internação psiquiátrica, para onde foi transferido ainda naquele mês de dezembro.

Em fevereiro de 2005 a equipe médica da instituição recomendou o encaminhamento de S8 para instituição socioeducativa em "regime fechado", na ocasião ele fazia uso controlado de psicotrópicos. Dois dias depois da recomendação, nas dependências do hospital psiquiátrico, S8 provocou a morte de outro paciente por asfixia. Foi imediatamente levado para a delegacia do adolescente, onde permaneceu por um mês até ser transferido para a unidade onde se realizou este trabalho.

O adolescente iniciou processo de psicoterapia em outubro de 2005. Seus comportamentos oscilavam freqüentemente de acordo com o clima da unidade, 
mostrando que o adolescente sujeitava-se às normas impostas por outros adolescentes, dificultando o processo terapêutico. O processo terapêutico foi interrompido e retomado três vezes devido a comportamentos inadequados do adolescente, que por vezes negavase a participar das sessões.

O participante 8 (S8) iniciou a psicoterapia em outubro de 2005 e passou por 23 sessões de psicoterapia, das quais 7 foram analisadas.

A Figura 29 abaixo mostra na distribuição linear das sessões, quais as analisadas.

\begin{tabular}{|l|l|l|l|l|l|l|l|l|l|l|l|l|l|l|l|l|l|l|l|l|l|l|l|}
\hline Sessões & 1 & 2 & 3 & 4 & 5 & 6 & 7 & 8 & 9 & 10 & 11 & 12 & 13 & 14 & 15 & 16 & 17 & 18 & 19 & 20 & 21 & 22 & 23 \\
\hline Analisadas & & & & & & & & & & & & & & & & & & & & & & & \\
\hline
\end{tabular}

Figura 29. Sessões de psicoterapia analisadas do participante S8.

É interessante notar na Figura 30 que a presença de comportamentos adequados de S2 já ocorria com pontuação máxima na quarta sessão, bem como nesta mesma sessão não há ocorrência de comportamentos inadequados. Porém, quando o adolescente foi confrontado acerca de seus comportamentos "ensaiados" para conquistar a confiança da terapeuta e ludibriá-la a fim de ser indicado para atividades externas, o que ocorre na quinta sessão, diminui a ocorrência dos "falsos" adequados e aparecem os inadequados que de fato faziam parte do repertório comportamental do adolescente. 


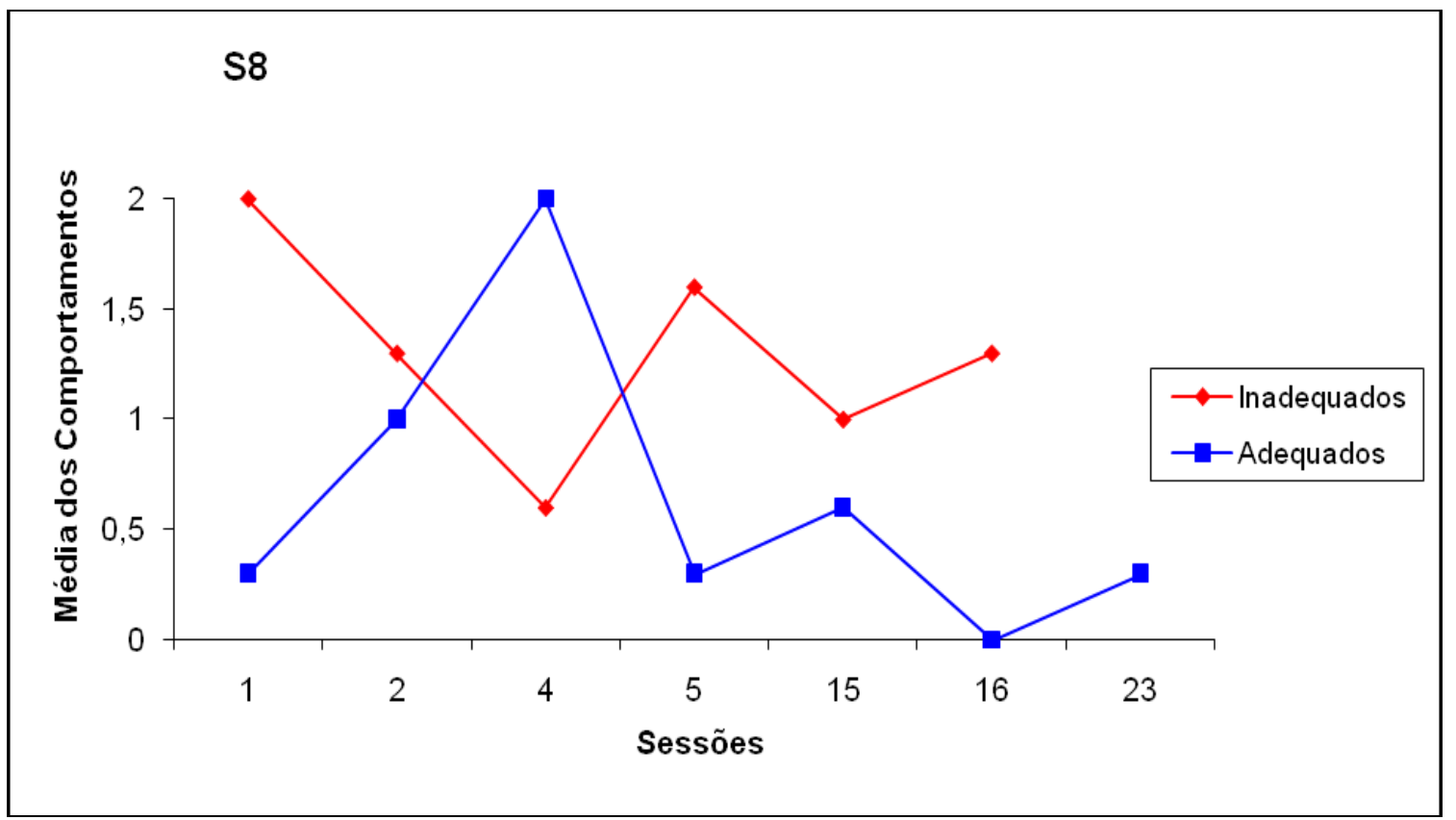

Figura 30. Média dos Comportamentos Inadequados e Adequados de S8 ao longo das sessões.

Observando-se a Figura 31 é possível notar que a média de comportamentos de reprovação (REP) é a mais alta dentre todos os adolescentes, igualando-se à recomendação (REC). Ainda assim são médias baixas se comparadas com informação (INF), empatia (EMP) e facilitação (FAC).

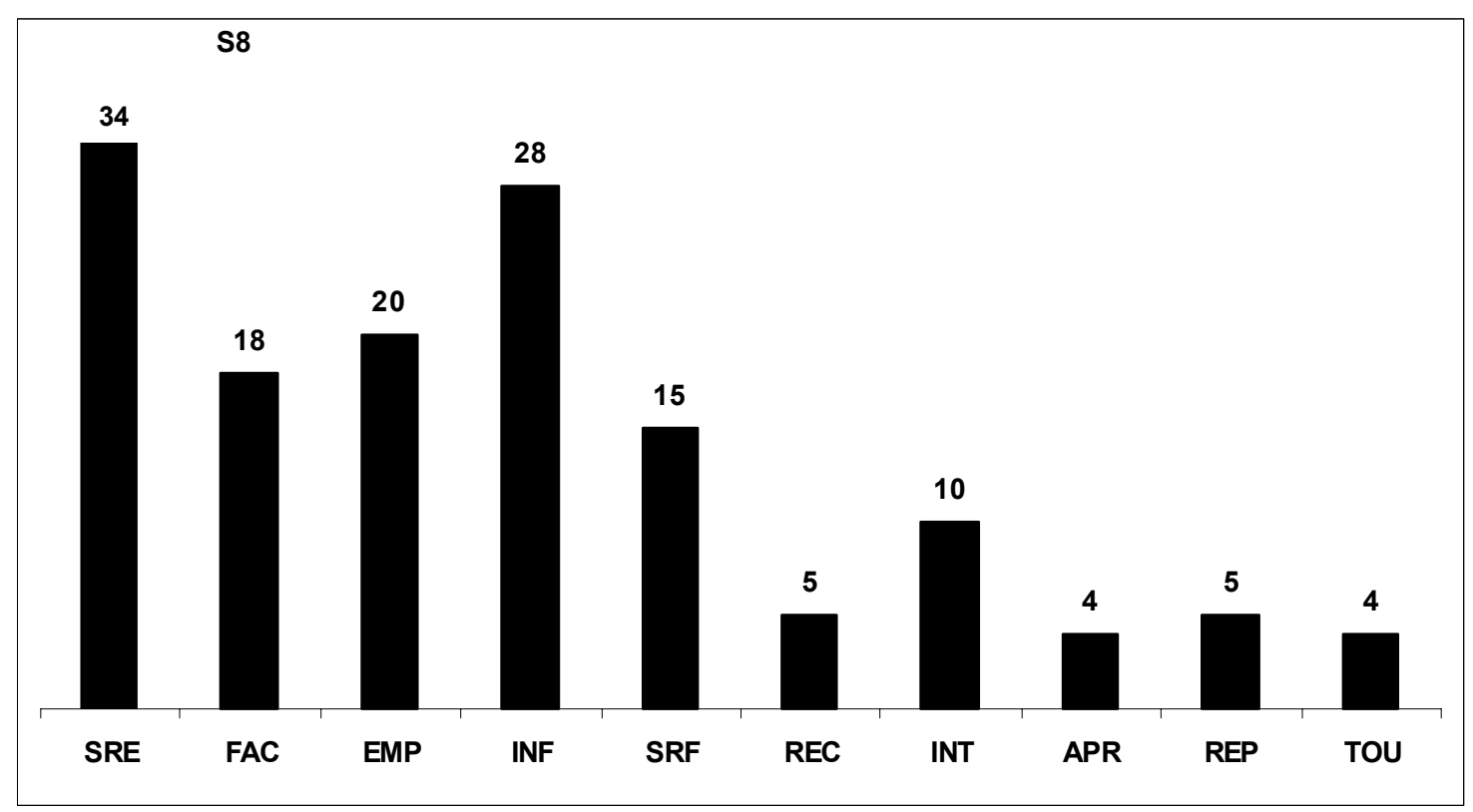

Figura 31. Média dos Comportamentos do Terapeuta nas sessões de S8. 
Uma das estratégias utilizadas nos atendimentos de S8 para interromper a emissão de comportamentos cuja função era manipular ou enganar a terapeuta era mudar de assunto. A terapeuta passava a relatar uma história ou narrar um fato externo à sessão e à unidade (INF) e pedia para S8 refletir sobre aquilo que fora narrado. O diálogo abaixo exemplifica esta estratégia.

S8: Ninguém me entende, eu não sei mais o que fazer para vocês acreditarem que eu quero mudar...

\section{$\mathrm{T}$ : (permanece em silêncio)}

S8: Eu sofro demais, daí fico tão desanimado que quero morrer, não quero mais nada dessa vida não... acho que to com depressão, to muito mal.

T: S8, você conhece a história do Pastorzinho e o Lobo ${ }^{15}$ ?

S8: Não.

T: Então vou contar para você... (conta história - INF)

Quando terminou a história, a terapeuta pediu para que S8 reflita (SRF) sobre porque esta história foi contada na sessão de hoje.

Utilizando o teste não-paramétrico de Spearman foram encontradas correlações positivas entre alguns comportamentos do terapeuta e do cliente nas sessões de psicoterapia:

- Outras verbalizações do terapeuta e sentimento positivo do Cliente $(\rho=.852)$

- Outras verbalizações do terapeuta e arrependimento do Cliente $(\rho=.771)$

Também foram encontradas as seguintes correlações negativas:

\footnotetext{
${ }^{15}$ O Pastorzinho e o Lobo é uma fábula atribuída à Esopo, na qual se conta a história de um menino que por diversão pedia socorro devido à presença de um lobo, mas na verdade não havia lobo e quando os vizinhos paravam seu trabalho e vinham salvar-lhe ficavam desapontados. Isto se repetiu por várias vezes, até o dia em que de fato havia um lobo, porém os vizinhos não mais vieram em socorro do garotinho.
} 
- Facilitação do terapeuta e auto-revelação do Cliente $(\rho=-.756)$

- Reprovação do terapeuta e sentimento positivo do cliente $(\rho=-.868)$

A correlação negativa encontrada entre auto-revelação do cliente provavelmente deva-se ao fato de que a terapeuta não utilizava este comportamento quando o cliente fazia auto-revelações, pois estas frequentemente tinham a função de ludibriar a terapeuta e os demais profissionais da unidade.

Devido ao histórico de vida, histórico infracional e padrões comportamentais de S8 observados pela terapeuta na rotina da unidade e durante as sessões de terapia, em poucos meses foi possível diagnosticá-lo com transtorno antisocial de personalidade (F 60.2) (DSM-IV-TR, 2002) com características psicopáticas. Sendo uma das principais características deste transtorno o padrão de comportamento sedutor e manipulador do individuo, sempre que isto era observado durante as sessões tomava-se o cuidado para não reforçar o comportamento, portanto o mesmo não era consequeciado com facilitações. As auto-revelações de S8 podem ser descritas como expressões verbais e gestuais de fazer-se de vítima de várias situações, com o cuidado de não culpar os outros abertamente, como os demais infratores o faziam.

A partir de várias informações coletadas através de prontuários, entrevistas com familiares e com o próprio adolescente foi possível utilizar a Escala Hare de Avaliação da Psicopatia (PCL-R) (Hare, 1991). Esta escala foi traduzida e validada para a população brasileira em 2004 (Morana, 2004) e oferece centenas de perguntas que devem ser preenchidas pelo próprio entrevistador. A partir dos dados coletados para responder a estas perguntas é possível então proceder à análise de vinte itens que determinarão o diagnóstico e grau de psicopatia em uma escala máxima de 
quarenta pontos. Os itens são pontuados através de uma escala ordinal onde 0 significa "Não", 1 significa "em alguns aspectos" e 2 significa "Sim".

A escala permite avaliar dois fatores da psicopatia, a insensibilidade afetiva (fator 1) e o comportamento anti-social (fator 2), e a maior pontuação em um dos fatores determina o tipo de psicopatia. $\mathrm{O}$ ponto de corte da escala para população brasileira é de 23 para o valor bruto. S8 obteve as pontuações expostas na Tabela 12, sendo portanto confirmado através do instrumento a presença de psicopatia.

Tabela 12. Pontuação da Escala PCL-R de S8.

\begin{tabular}{cccc}
\hline $\begin{array}{c}\text { Fator 1 } \\
\text { Insensibilidade } \\
\text { Afetiva }\end{array}$ & $\begin{array}{c}\text { Fator 2 } \\
\text { Comportamento } \\
\text { Anti-social }\end{array}$ & Total & \\
\hline 13 & 10 & 25 & Bruta \\
14,9 & 11,3 & 26,3 & Ponderada \\
97,6 & 51,1 & 63,5 & Percentil \\
\hline
\end{tabular}

S8 era observador e perspicaz. Quando percebia que a terapeuta reprovava algum comportamento dele ou de outra pessoa, imediatamente agia de forma diferente da reprovada. Sempre que algum comportamento recebia esta conseqüência (reprovação) S8 calava-se, cruzava os braços e baixava a cabeça. Portanto, é possível supor que a correlação negativa encontrada entre expressão de sentimento positivo e reprovação ilustre situações (por exemplo as de reprovação) nas quais o adolescente percebia não ser vantajoso emitir tal comportamento.

Um grave erro cometido com este jovem, mas que de certa forma ajudou a compreender seu padrão comportamental, foi colocá-lo em um grupo para desenvolvimento de habilidades sociais. Ele rapidamente aprimorou estas habilidades, fazendo com que técnicos (professores, médicos e enfermeiros) e educadores da unidade avaliassem positivamente sua capacidade de interação e considerassem-no um dos jovens mais aptos para o desinternamento. Importante ressaltar que nenhum dos 
outros adolescentes implementou estes comportamentos tão rapidamente quanto S8 após a participação neste tipo de atividade.

Portanto, ao contrário do que alguns autores citam como sendo necessário ao tratamento dos indivíduos com este padrão comportamental (Caballo e Torrecillas, 2008), estes não podem ser incluídos neste tipo de atividade, pois utilizam o que deveria ser um benefício para manipular e enganar os demais.

Como exemplo pode-se apresentar alguns escritos (Figuras 32, 33 e 34) de S8 realizados semanas após a participação nas sessões de treino em habilidades sociais no mês de outubro.

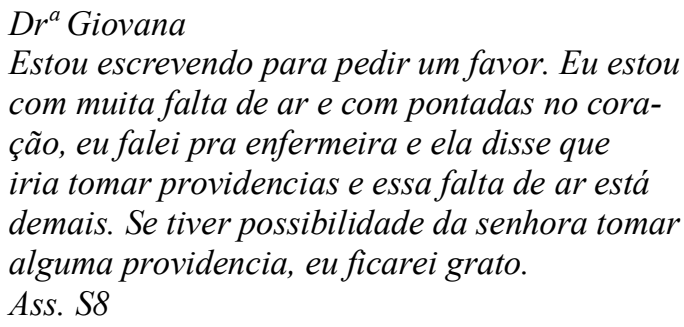

Figura 32. Bilhete de S8 para a terapeuta.

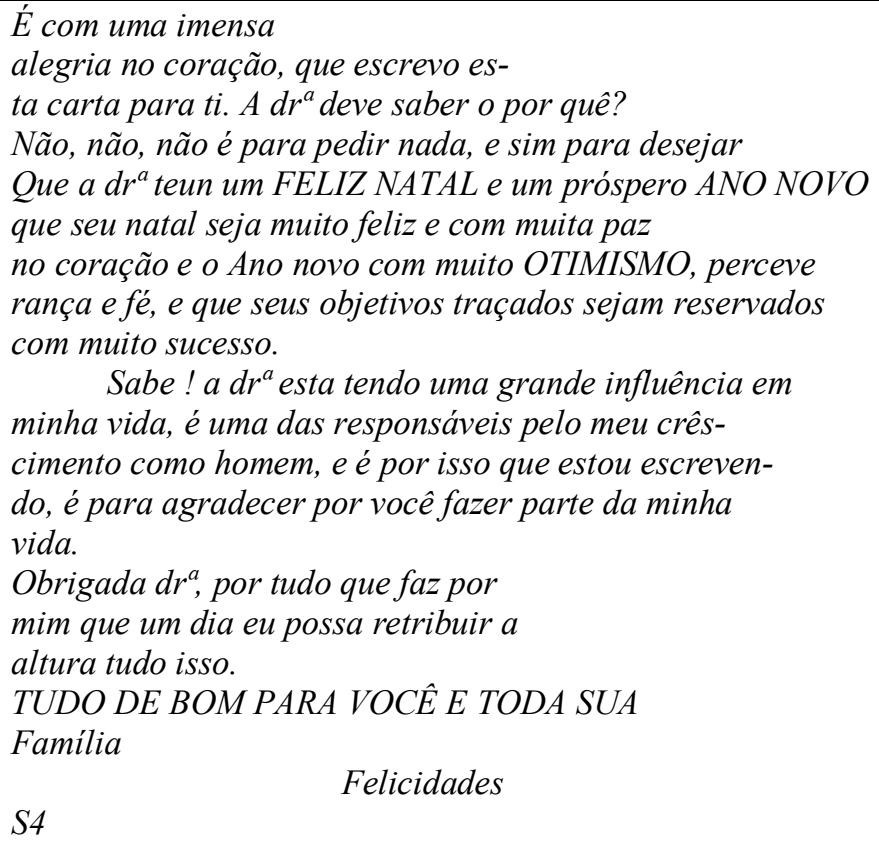

Figura 33. Carta de Natal de S8 para a Terapeuta. 


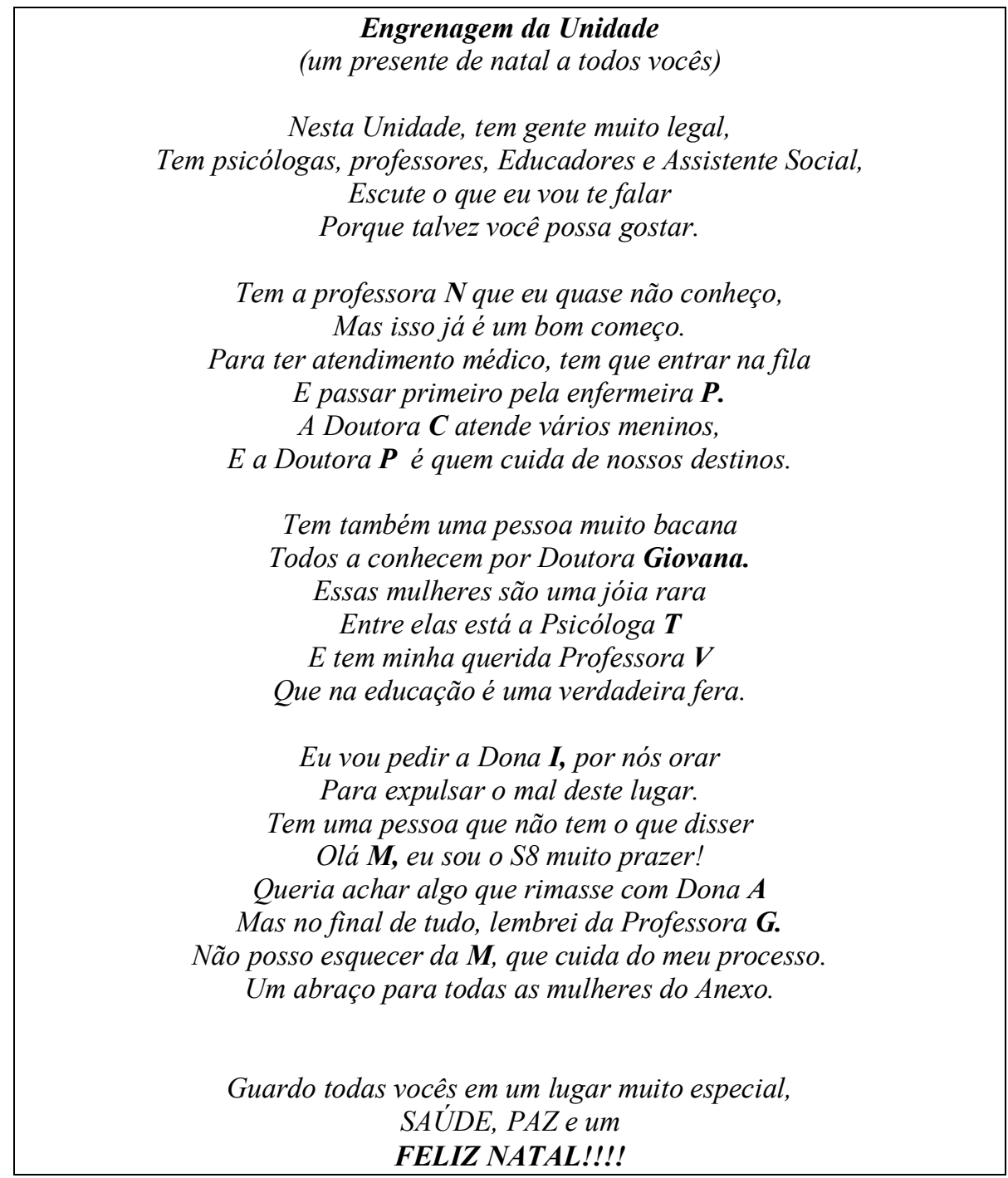

Figura 34. Homenagem de Natal de $\mathrm{S} 8$ para todas as mulheres que trabalhavam na unidade.

Sobre as práticas educativas dos cuidadores de S8 é preciso lembrar que este adolescente respondia a qualquer tipo de inventário ou mesmo a perguntas no contato terapêutico fornecendo informações que ele julgava serem as adequadas ou desejáveis. Portanto foi necessário confrontá-lo durante a aplicação do IEP para obter os resultados expostos na Tabela 13. Ainda assim, principalmente devido às entrevistas realizadas com a mãe e com a tia, foi possível manter o ceticismo quanto às respostas que indicavam haver monitoria positiva e existência de pouca negligência da mãe. 
Dados que corroboram para esta assertiva é de que a mãe primeiramente não desejava manter o filho consigo até que percebeu que havia perdido a possibilidade de receber apoio financeiro dos pais e da irmã não criando o filho e assim não tendo custos que justificassem que eles lhe dessem dinheiro. Foi então que ela tirou o menino do convívio da tia pela primeira vez e o levou com ela. Ela deixava-o sozinho sem comida e higiene por horas, retornava para o quarto alugado alcoolizada e muitas vezes trouxe homens com quem fazia sexo na presença do filho. $\mathrm{Na}$ época em que estes fatos ocorreram, vizinhos da mãe de S8 contaram para a tia dele o que estava acontecendo e ela retirou o menino da situação, ofertando dinheiro para a mãe dele.

Tabela 13. Práticas educativas dos cuidadores de $\mathrm{S} 8$ avaliadas através do Inventário de Estilos Parentais.

\begin{tabular}{|c|c|c|c|c|c|c|c|c|}
\hline IEP S8 & لَّ & 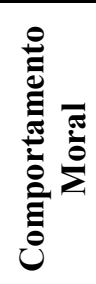 & 导 & 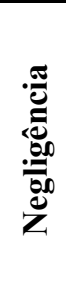 & 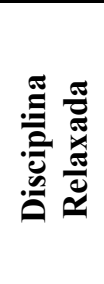 & & 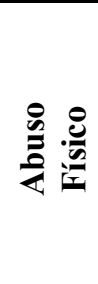 & IEP \\
\hline IEP Tia & 8 & 9 & 5 & 3 & 7 & 10 & 4 & -12 \\
\hline IEP Materno & 11 & 9 & 8 & 2 & 5 & 10 & 5 & -10 \\
\hline IEP Tio & 9 & 11 & 10 & 3 & 1 & 7 & 7 & -10 \\
\hline
\end{tabular}

É possível observar como práticas negativas comuns a todos os que desempenharam função de cuidadores em momentos diferentes da infância de S8 a punição inconsistente, a monitoria negativa e o abuso físico. O resultado total do IEP de todos eles indica Estilo Parental de Risco.

Gomide (2001) aponta que os comportamentos da criança que derivam da utilização de punição inconsistente, ou humor instável dos pais, relacionam-se à manipulação, pois os filhos aprendem a discriminar o humor dos pais e não o que é certo e errado ou valores. Crianças que são educadas com esta prática aprendem a chantagear emocionalmente, o que era visível e constante nos comportamentos de S8. 
A monitoria negativa faz com que a criança fortaleça comportamentos de mentir e enganar, pois é assim que escapam do controle excessivo e punições nãocontingentes que fazem parte desta prática. Outros efeitos relacionam-se ao afastamento que a criança faz de seus cuidadores (Gomide, 2001). Este afastamento se mostra eficaz, pois faz diminuir a aversividade das cobranças excessivas, porém facilita a aproximação da criança de pares desviantes e desta forma a aproximação de drogas, álcool e comportamento anti-social se torna rápida e eficaz. Todos estes efeitos da monitoria negativa foram observados em S8.

O abuso físico, geralmente acompanhado do psicológico, atinge diretamente a formação do autoconceito e da auto-estima da criança, que aprende através da agressão que não presta, não tem valor, não faz nada certo, enfim, que é um fracasso, que é má e um erro (Gomide, 2001). Estes sentimentos de menos valia são as brechas de aproximação do grupo desviante, pois os pares oferecem uma valorização que não era conhecida em casa. Contudo, esta valorização está calcada em comportamentos desviantes, socialmente reprováveis e anti-sociais.

Diferente do adolescente S2, cujo padrão de comportamento é semelhante ao de S8, este mostrava habilidades de manipulação e mentira mais elaboradas e agressividade mais contida. Raramente observava-se alguma agressividade física em S8. No crime cometido no hospital psiquiátrico o adolescente planejou e comandou toda a execução sem tocar na vítima, fazendo com que outros o fizessem por ele. Quando foi retirado do hospital e levado para a delegacia durante todo o trajeto foi cantando cantigas de roda $^{16}$, simulando um quadro psiquiátrico que deixou policiais e técnicos assustados, preocupados e amedrontados. Vários meses depois, já na unidade de internamento onde se realizou este trabalho, S8 orientou um outro adolescente (S3)

\footnotetext{
${ }^{16}$ A música mais cantada e que se tornou marca do adolescente naquela ocasião foi "Quem quer casar com a Dona Baratinha, que tem fita no cabelo e dinheiro na caixinha?"
} 
para que se comportasse de determinada maneira a fim de "conquistar" a confiança da terapeuta. Porém, tal adolescente não suportou a aversividade da situação e revelou este fato para a terapeuta, contando também que S8 declarara ter cantando aquelas músicas na ocasião do homicídio do hospital para botar medo nas pessoas e ganhar respeito dos outros presos.

$\mathrm{O}$ processo de S8 foi interrompido pela psicoterapeuta, que quando vislumbrou possibilidade de retomá-lo não o fez em virtude de sua iminente saída da Unidade (fato descrito na Apresentação deste trabalho).

\section{S9: O GLADIADOR}

Nascido no início de 1988 o jovem S9 apresentou mudanças comportamentais significativas ao longo do processo, sendo um exemplo de que é possível ter recaídas e superá-las.

A mãe de S9 era portadora de transtorno psiquiátrico, provavelmente esquizofrenia, e era alvo de grande preocupação do jovem. Uma das irmãs também tinha o mesmo transtorno, com comportamentos ainda mais desorganizados.

O pai faleceu em 1987 em confronto com a polícia e deixou a viúva e cinco filhos. Era violento, usava maconha, álcool e agredia a mãe de S9. Em 1998 o filho mais velho também morreu em confronto com a polícia. Das três moças, uma vivia com a mãe, outra era casada tinha filhos e residia com o marido, e a última, portadora de distúrbio psiquiátrico, morava sozinha e sobrevivia com a pensão por invalidez que recebia do governo.

S9 iniciou aos nove anos o consumo substâncias entorpecentes e a prática de pequenos furtos para manter o vício. Mais tarde os furtos se tornaram seu sustento. 
S9 encontrava-se cumprindo medida socioeducativa de internamento em função de um homicídio desde abril de 2004. Participou da rebelião de setembro de 2004 e considerado uma das lideranças foi transferido em fevereiro de 2005 para a unidade onde se realizou a pesquisa. Em abril de 2005 (depois de seis sessões de psicoterapia) empreendeu fuga durante uma atividade profissionalizante realizada fora da unidade. Em maio foi aprendido depois de cometer diversos roubos e retornou para a unidade.

S9 iniciou a psicoterapia antes de sua fuga da unidade. Quando retornou (no mês de maio), após uma conversa bastante difícil com a psicóloga, ficou acordado que ele poderia pensar em retomar o processo sem mentiras. Após várias semanas ele solicitou atendimento e a partir de então teve modificações comportamentais importantes. Fez vínculo com a psicoterapeuta e com ela falava de suas dúvidas, medos e dificuldades. Neste processo S9 revelou sua vida infratora, que antes era minimizada em seus relatos. Ele compreendeu os fatores ambientais, tais como a vizinhança, amigos e a própria família, e a influência destes fatores em sua vida infracional. Relatou uma forte ligação com o irmão falecido e uma grande preocupação com a irmã que tem problemas psiquiátricos.

No início do ano de 2006 em seu aniversário ele recebeu dos funcionários da instituição uma festa de aniversário (à qual nenhum familiar seu compareceu). Ele demonstrou emoções condizentes com a situação e solicitou à diretora da unidade que fosse convidada uma antiga assistente social da unidade para que ele se desculpasse com ela. Em novembro de 2005 S9 acertou-a com uma cadeira de plástico durante um atendimento, precipitando a saída da profissional da unidade. 
O participante 9 (S9) iniciou a terapia em março de 2005 e passou por 26 sessões de psicoterapia, das quais 9 foram analisadas.

A Figura 35 abaixo mostra na distribuição linear das sessões, quais as analisadas. Não foi possível analisar sessões do final do processo porque três delas estavam danificadas (21, 22 e 23), duas estavam parcialmente inaudíveis (18 e 19) e não foi feita gravação a pedido do cliente nas sessões realizadas quando ele já estava em liberdade $(24,25$ e 26$)$.

\begin{tabular}{|c|c|c|c|c|c|c|c|c|c|c|c|c|c|c|c|c|c|c|c|c|c|c|c|}
\hline \multirow{2}{*}{$\begin{array}{l}\text { Sessões } \\
\text { Analisadas }\end{array}$} & 1 & 2 & 3 & 4 & 5 & 6 & 7 & 8 & 9 & 10 & 11 & 12 & 13 & 14 & 15 & 16 & 17 & 18 & 19 & 20 & 21 & 22 & 23 \\
\hline & & & & & & & & & & & & & & & & & & & & & & & \\
\hline & 24 & 25 & 26 & & & & & & & & & & & & & & & & & & & & \\
\hline
\end{tabular}

Figura 35. Sessões de psicoterapia analisadas do participante S9.

Na Figura 36 é preciso indicar que a fuga do adolescente aconteceu após a sétima sessão, na sexta sessão deixaram de ocorrer comportamentos inadequados e ocorreram alguns adequados. A oitava sessão ocorreu quando ele foi reaprendido.

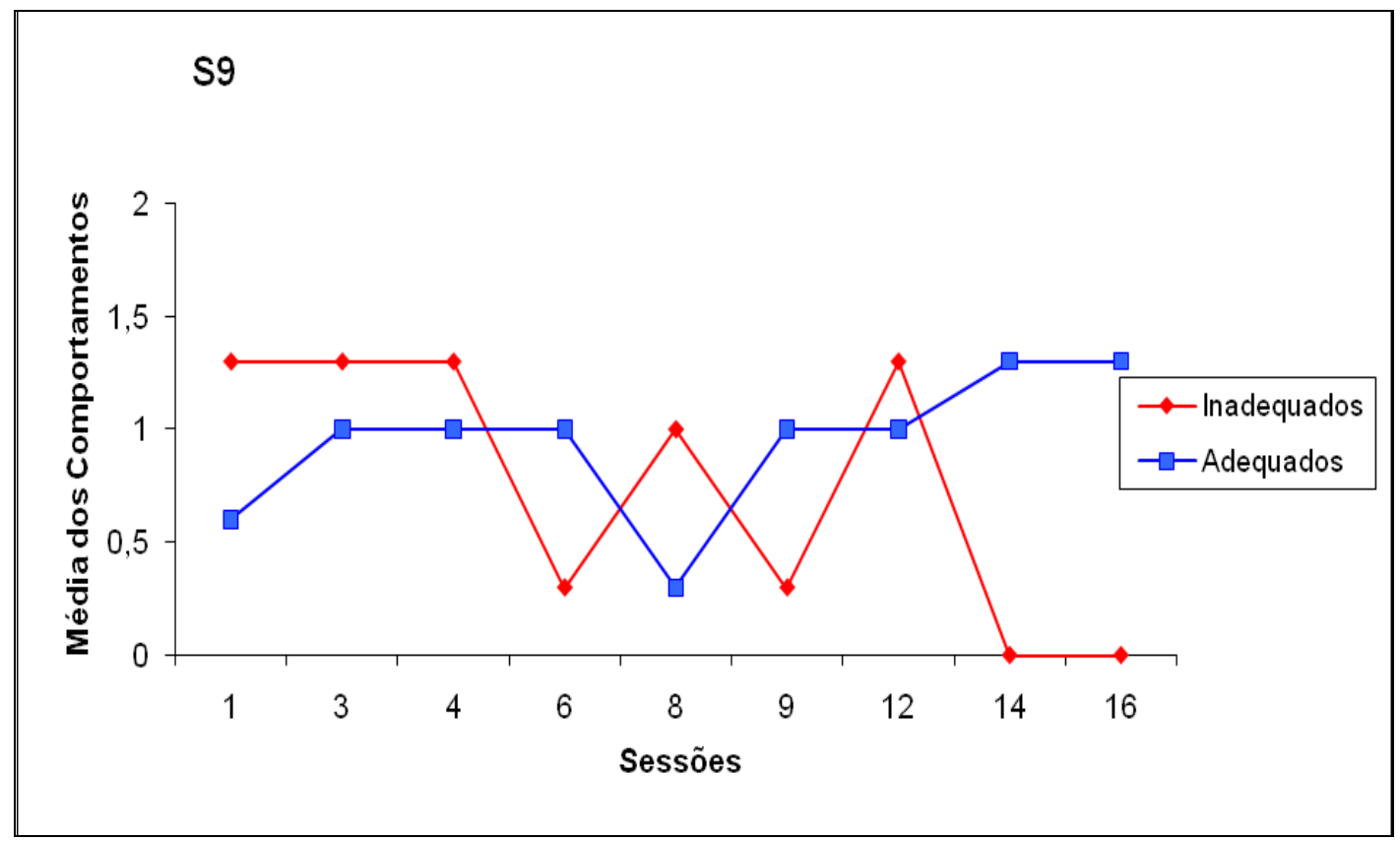

Figura 37. Média dos Comportamentos Inadequados e Adequados de S9 ao longo das sessões.

$\mathrm{Na}$ oitava sessão, dias após seu retorno à unidade, S9 foi duramente confrontado pela psicoterapeuta e então apareceram comportamentos inadequados na 
sessão. Houve então uma interrupção de cinco meses no processo terapêutico, que foi retomado apenas quando o jovem manifestou interesse de voltar a encontrar a terapeuta.

Na Figura 36 é possível notar a presença de comportamentos adequados já na nona sessão, quando o adolescente desculpa-se com a terapeuta e diz que reconhece ter a enganado no início do ano por ocasião da fuga. A décima segunda sessão aponta para um aumento de comportamentos inadequados e faz-se necessário explicar que todos eles foram relativos aos relatos acerca do envolvimento de S9 com o crime. Sendo assim, também foi significativa a presença de comportamentos adequados já que o jovem fez estes relatos espontaneamente em forma de auto-revelações com a finalidade de "não deixar nenhuma mentira entre eu e a senhora"(SIC).

Quanto aos comportamentos da terapeuta é necessário apontar que além das semelhanças com os demais casos quanto aos comportamentos de reprovação (REP), aprovação (APR) e recomendação (REC), há diferenças significativas quanto à média geral de comportamentos emitidos pela terapeuta nos outros casos.

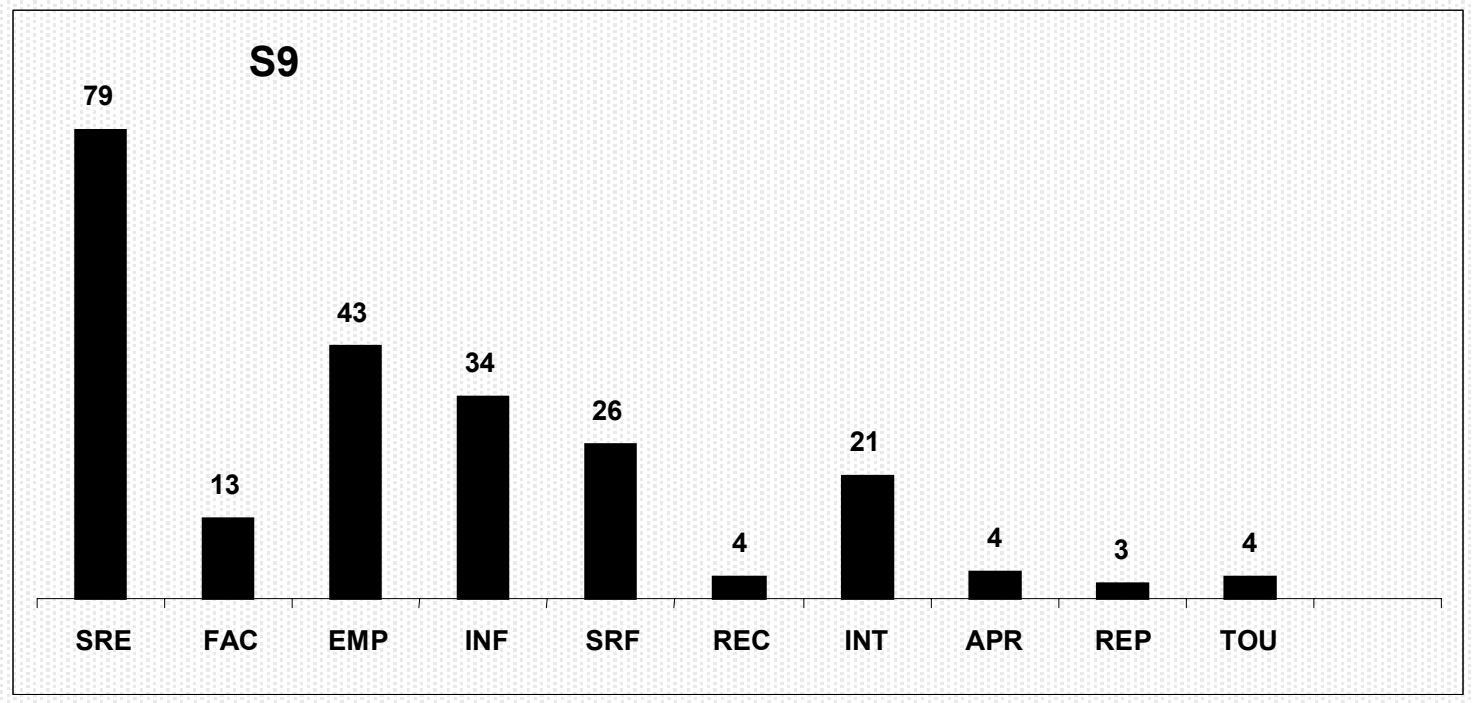

Figura 37. Média dos comportamentos do terapeuta no processo de S9.

Nota-se na Figura 37 a mais elevada média de comportamentos de empatia (EMP) por sessão dentre todos os atendimentos. A média geral deste comportamento da terapeuta ao longo dos atendimentos de todos os adolescentes foi de 
17 registros, enquanto neste caso foi de 43. A média geral de solicitação de relatos (SRE) foi de 40 ocorrências por sessão, neste caso foi de 79. A ocorrência geral de solicitação de reflexão (SRF) foi de 14 e neste caso também foi superior, apresentando média de 26 ocorrências por sessão. Estes dados parecem indicar uma alta interação entre cliente e terapeuta.

Utilizando o teste não-paramétrico de Spearman foram encontradas correlações positivas entre alguns comportamentos do terapeuta e do cliente nas sessões de psicoterapia:

- Solicitação de relato do terapeuta e mentira do Cliente $(\rho=.807)$

- Informações do terapeuta e hostilidade do Cliente $(\rho=.914)$

- Informações do terapeuta e culpar do Cliente $(\rho=.603)$

Mais uma vez, a correlação positiva entre solicitação de relato do terapeuta e mentira do cliente explicita um importante aspecto desta relação terapêutica: o adolescente infrator possui um amplo repertório comportamental baseado na mentira e enquanto não desenvolver repertório não infrator continuará utilizando deste comportamento em suas interações. Como o número de solicitações de relato por parte do terapeuta tende a ser mais elevado no início do processo terapêutico, exatamente quando ainda não se tem vínculo formado, parece lógico que esta relação positiva se estabeleça.

Especialmente com S9, quando a terapeuta apresentava informações, estas eram seguidas por hostilidade do cliente que atribuía, devido à sua história de vida, à explicação dada através da informação o sentido de estar sendo chamado de burro. Quando o mesmo expressou este sentimento a terapeuta explicou que a função do comportamento não era aquela e passou a utilizar este tipo de relato informativo com cautela. Porém, quando S9 apresentava-se hostil ou narrava hostilidade expressa contra 
outras pessoas, a terapeuta ao invés de interpretar o comportamento do cliente consequenciava-o com informações que possibilitassem reflexão sobre o fato, mas que não provocassem a escalada da hostilidade do cliente. O mesmo se aplica ao comportamento do cliente de culpar outras pessoas pelos próprios comportamentos, o que no caso dele, geralmente estava associado à hostilidade $(\rho=.742)$.

O comportamento de hostilidade de S9, expresso por vezes através da violência física, estava relacionado ao repertório comportamental dos pais e às práticas educativas dos mesmos. O pai era infrator, homem temido na região onde moravam pela violência e crueldade com que tratava seus inimigos. Pouco agredia fisicamente o filho, mas agredia a esposa na presença dos filhos. Esta por sua vez era instável e agressiva devido a um quadro psiquiátrico grave. S9 relata que a mãe brigava com as panelas e atirava-as longe quando alguma coisa queimava ou saia errada na cozinha. Ele também presenciou discussões da mãe na rua, no supermercado e na igreja, sempre com o tema religião, e nestas situações relatou que ficava com medo e assustado pois a mãe "virava num bicho" pregando para aqueles que estavam associados ou possuídos pelo demônio.

Tabela 14. Práticas educativas dos cuidadores de S9 avaliadas através do Inventário de Estilos Parentais.

\begin{tabular}{|c|c|c|c|c|c|c|c|c|}
\hline IEP S9 & 竧 & 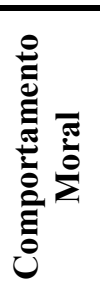 & 总 & 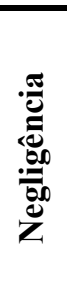 & 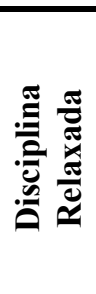 & 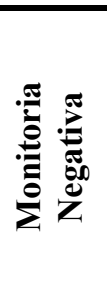 & 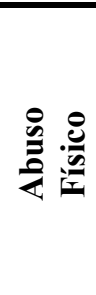 & IEP \\
\hline IEP Materno & 9 & 11 & 5 & 0 & 7 & 9 & 1 & -2 \\
\hline IEP Paterno & 9 & 8 & 4 & 5 & 6 & 9 & 1 & -8 \\
\hline
\end{tabular}

Tanto as práticas educativas totais do pai quanto as da mãe de S9 encontravam-se na faixa que Gomide (2006) classifica como "Estilo Parental de Risco".

Observando a Tabela 14 é facilmente compreensível, devido às histórias de vida dos pais de S9, que ambos os cuidadores fizeram uso excessivo de disciplina relaxada e monitoria negativa. A punição inconsistente da mãe explica-se pelo humor 
instável devido ao comprometimento psiquiátrico. Além do modelo fornecido pelo pai, que possuía um rico repertório infrator, bem como o irmão mais velho de $\mathrm{S} 9$, estas práticas contribuíram para o envolvimento dele com drogas, tráfico e posteriormente com roubos e homicídio.

S9 era respeitado no mundo do crime, possuía uma liderança natural, era considerado pelos demais adolescentes como uma pessoa de palavra, leal e "honesto". Sendo assim é possível notar que S9 possuía autoconceito construído com base nos comportamentos anti-sociais e seus valores eram aqueles da "lei do crime". Estes valores foram mais fortes do que os religiosos pregados pela mãe através da monitoria negativa e sem consistência, como é típico da disciplina relaxada.

Era evidente que o repertório do qual este jovem dispunha era apenas o infrator. Utilizando-se de práticas educativas adequadas e consistentes na psicoterapia, a terapeuta ofertou novos modelos de comportamento e resoluções de problemas, que eram rapidamente compreendidos pelo jovem que era dotado de ótima capacidade cognitiva. S9 inclusive concluiu o ensino fundamental na unidade e iniciou o ensino médio. Completou o curso de padeiro e confeiteiro e era elogiado pelos professores.

\section{S10: O REBELDE}

Nascido no ano de 1987 este adolescente sempre fora considerado uma criança de temperamento difícil e hiperativo. Não possuía extenso histórico infracional como os demais participantes deste estudo. Sua família também não possuía antecedentes criminais. S10 era filho adotivo, o mais novo de uma prole de oito. Sua família vivia da agricultura e este também era o ofício realizado pelo rapaz nas horas em que não se encontrava na escola. Com o dinheiro de seu trabalho S10 comprou uma motocicleta no ano de 2004. Desinformado sobre questões de impostos relativos ao 
veículo perdeu-a em uma apreensão da policia rodoviária. Os impostos somavam o dobro do valor da motocicleta. Curioso é que os mesmos policiais não o autuaram pela falta de documentação para conduzir o veículo, uma vez que ele era menor de idade. Numa última tentativa de reaver o bem, S10 dirigiu-se à delegacia com todos os documentos de compra tentando argumentar que comprou a motocicleta e que aqueles valores eram devidos pelo proprietário anterior. O jovem sentiu-se humilhado pelos oficiais que riram dele e disseram que se ele pagasse uma quantia determinada a eles, em forma de propina, a moto seria liberada rapidamente.

O adolescente contou que sentiu uma raiva muito grande e decidiu que arranjaria dinheiro para comprar outra moto, mas que não daria dinheiro para aqueles "vermes". Lembrou-se que sentiu muita tristeza e desânimo e que pensou que teria que trabalhar mais uns quatro anos para juntar dinheiro novamente.

Certa noite estava em um bar jogando pebolim quando uns rapazes da escola perguntaram se ele queria ganhar um dinheiro extra. S10 aceitou, combinando que sua função seria dirigir um carro que havia sido roubado em uma cidade próxima, até uma outra cidade da região. Disse que ficou com medo, mas que bebeu bastante e pensava somente em comprar a motocicleta. O carro a ser roubado estava em lugar ermo da cidade, onde jovens estacionavam para namorar. Quando abordaram o casal S10 percebeu que era um primo seu com a namorada e a moça estava nua. Um dos colegas do jovem sinalizou que iria aproveitar a situação e transar com a moça. S10 reagiu e disse que isso não aconteceria, foi aí que mesmo usando uma máscara ele foi reconhecido pelo primo. O casal foi amarrado e levado até um matagal onde foram deixados. Porém, o assalto configurou-se como seqüestro pois um dos rapazes voltou ao local onde havia abandonado o casal e levou-os para uma casa. O casal conseguiu fugir e quando chegaram à delegacia S10 foi denunciado. 
O adolescente foi apreendido em outubro de 2004 e recebeu medida de internamento em novembro de 2004. Devido a seu temperamento difícil, tipicamente opositor, S10 foi avaliado como um jovem perigoso e foi transferido em fevereiro de 2005 para a unidade onde este trabalho aconteceu.

O participante 10 ( $\mathrm{S} 10)$ passou por 10 sessões de psicoterapia, que iniciaram em junho de 2005 e das quais sete foram analisadas.

A Figura 38 abaixo mostra na distribuição linear das sessões, quais as analisadas.

\begin{tabular}{|l|l|l|l|l|l|l|l|l|l|}
\hline Sessões & 1 & 2 & 3 & 4 & 5 & 6 & 7 & 8 & 9 \\
\hline Analisadas & & & & & & & & & \\
\hline
\end{tabular}

Figura 38. Sessões de psicoterapia analisadas do participante S10.

Conforme é possível identificar na Figura 39 este adolescente sempre apresentou mais comportamentos adequados do que inadequados. Apesar dos adequados permanecerem mais altos que os inadequados, é importante descrever o contexto das últimas sessões analisadas. S10 já estava em liberdade a partir da sexta sessão e além de toda ansiedade decorrente de estar morando em lugar diferente, conhecendo novas pessoas e trabalhando, o jovem mostrava-se constantemente descontente com as dificuldades com as quais se deparava. Então ele reclamava em demasia de situações que eram reais, mas para as quais ele ainda não tinha repertório para encarar. Isto ocorreu principalmente no período em que S10 morou em uma casa de semi-liberdade do governo e lá vivenciou várias situações de injustiça, perseguição e descaso por parte de técnicos, adolescentes traficando e consumindo drogas, dentre outras situações absurdas se for pensado que ocorriam em uma ambiente que deveria ser de reinserção social. 


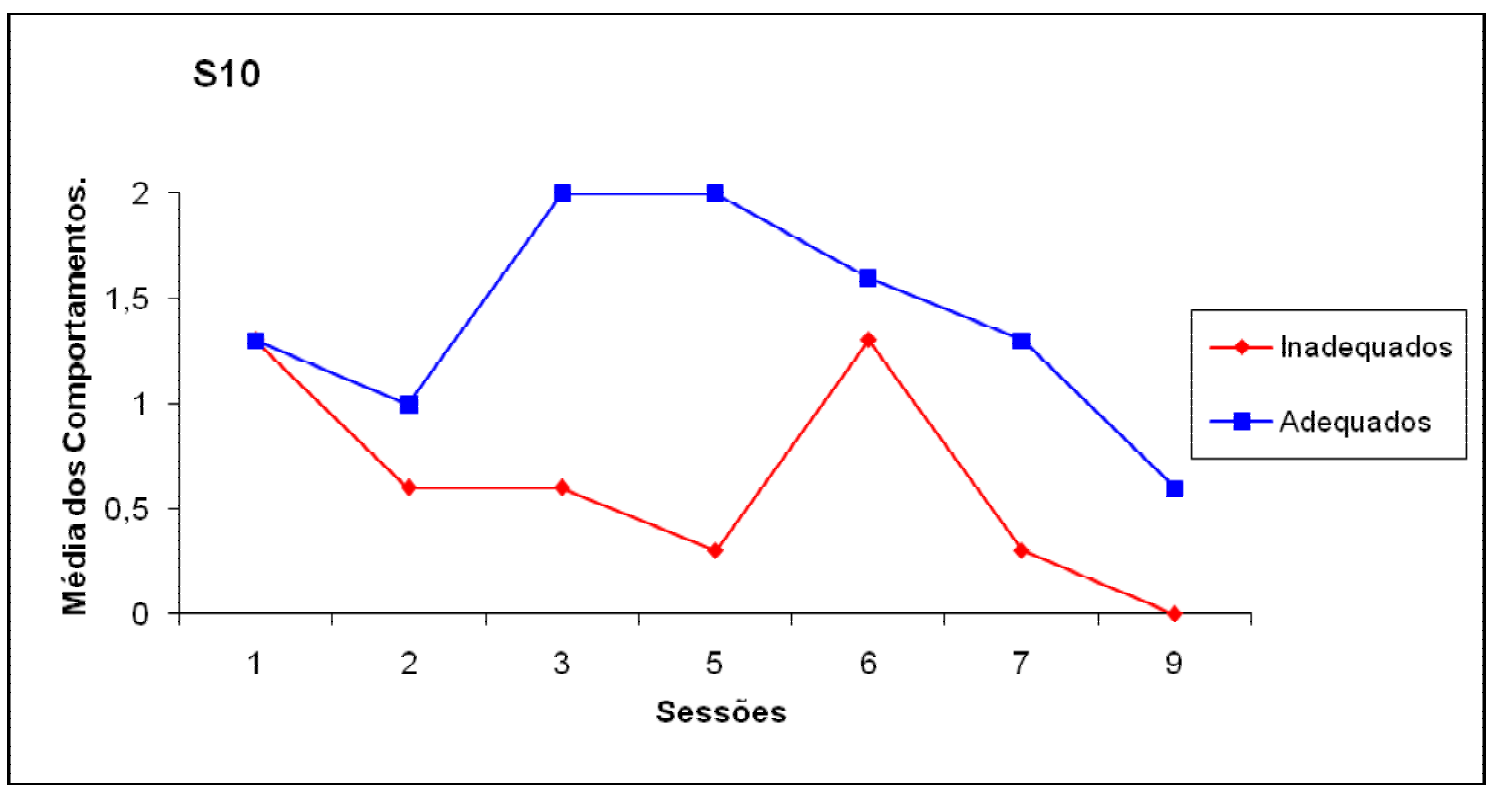

Figura 39. Média dos Comportamentos Inadequados e Adequados de S10 ao longo das sessões.

A média de comportamentos de Solicitação de Relato (SRE) (Figura 40) nas sessões de S10 é a mais baixa dentre todos os adolescentes, o que possibilita supor que isto se relaciona ao fato de que este adolescente falava muito e espontaneamente. Já a empatia apresenta a terceira maior média dentre todos os adolescentes, indicando provavelmente que devido ao fato de S10 relatar sentir-se pouco compreendido em vários momentos de sua história de vida, a terapeuta utilizava-se amplamente deste comportamento.

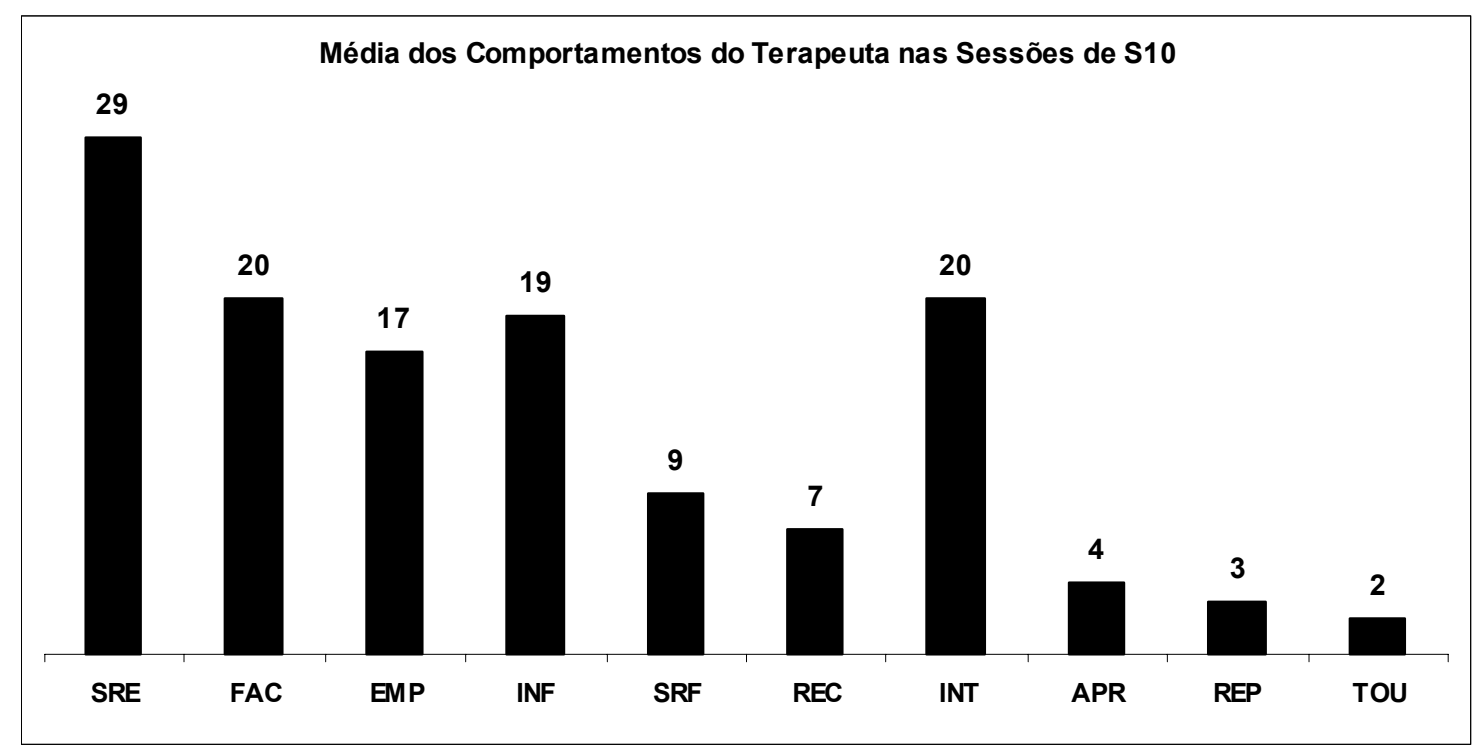

Figura 40. Média dos Comportamentos do Terapeuta nas Sessões de S10. 
Utilizando o teste não-paramétrico de Spearman foram encontradas correlações positivas entre alguns comportamentos do terapeuta e do cliente nas sessões de psicoterapia:

- Solicitação do relato do terapeuta e mentira do cliente $(\rho=.748)$

- Facilitação do terapeuta e mentira do cliente $(\rho=.809)$

- Empatia do terapeuta e mentira do cliente $(\rho=.802)$

- Solicitação de reflexão do terapeuta e mentira do cliente $(\rho=.757)$

- Aprovação do terapeuta e mentira do cliente $(\rho=.693)$

- Outras verbalizações do terapeuta e mentira do cliente $(\rho=.1)$

- Informação do terapeuta e arrependimento do cliente $(\rho=.926)$

- Reprovação do terapeuta e culpar do cliente $(\rho=.686)$

Vários comportamentos do terapeuta foram correlacionados positivamente com o comportamento de mentir do cliente, o que é curioso tendo em vista a baixa freqüência de ocorrência deste comportamento do cliente (ocorreu apenas duas vezes em todo o processo). A principal característica comportamental infratora de S10 não era a mentira, e sim o responsabilizar outras pessoas pelos próprios comportamentos impulsivos.

Já a correlação positiva entre reprovação do terapeuta e culpar do cliente, mais uma vez como em outros casos já discutidos, parece ter uma propriedade bidirecional, sendo antecedente ao comportamento de culpar os outros apresentado pelo cliente e também podendo ser um conseqüente a este mesmo comportamento de responsabilizar os outros.

Uma das estratégias utilizadas pela terapeuta especialmente com este cliente pode explicar a correlação positiva entre o comportamento do terapeuta de fornecer informação e o comportamento adequado do cliente de expressar 
arrependimento. S10 mostrava descontentamento e resistência para participar de intervenções nas quais seu comportamento era explicitamente exposto e avaliado. Portanto, as estratégias de Interpretação (descrição de contingências) e de Solicitação de Reflexão pareciam tornar as sessões aversivas para o cliente e proporcionavam antecedentes para a emissão de comportamentos do cliente de responsabilizar os demais ou então de calar-se impedindo a continuidade da sessão.

Desta forma, a terapeuta expunha análises semelhantes através da narrativa de fatos genéricos não relativos ao cliente, mas que visavam a compreensão de S10 acerca de relações entre contingências semelhantes àquelas que faziam parte de seus problemas e dificuldades. Assim S10 participava ativamente, dava opiniões e acabava por refletir acerca dos próprios comportamentos inadequados.

Como exemplo tem-se o diálogo abaixo:

S10: Os guarda entrarô aí e fizeram o maior estrago... Pilantrage isso...

T: O que é pilantragem? (SRE)

S10: Os educador chama os hómi pra resolve o que é poblema deles.

T: Mas se estava ficando uma situação muito séria, é tarefa deles chamar a polícia.(INT)

S10: Ara que é! Eles adora ver o circo pegando fogo, isso sim!

T: Você já assistiu filmes de guerra? (SRE) Então, no exército os soldados recebem um treinamento para aprender a controlar o medo, a ansiedade. Porque quando aprendem a controlar a ansiedade eles pensam melhor em situações de crise e de pressão. (INF)

S10: Eu tenho um primo que serviu exército. Ele tinha cabeça boa mesmo. 
T: A ansiedade faz ficar tudo confuso, difícil de raciocinar. O corpo todo muda, o coração bate mais rápido, a respiração fica ofegante... (INF)

S10: O que que é ofegante?

T: É quando o ritmo da respiração fica dificultado (INF), assim (...) sabe? Então, tem técnicas pra controlar a ansiedade, jeitos pra controlar nosso corpo em momentos difíceis, inesperados, e assim poder pensar direito. (INF)

S10: Ah! Eu sei o que é! Aquelas coisa de relaxamento.

T: Isso mesmo! (APR) E você já fez? (SRE)

S10: Não... Esqueci, sei lá... Fiquei com vergonha... Mas podia fazer isso né, quando a policia entra, daí eu podia ficar mais calmo sei lá... eles acaba o dia da gente quando entra aqui...

T: Eles acabam com o dia quando entram aqui... (Paráfrase crítica REP)

S10: É, mas eu podia ficar melhor quando eles sai, não adianta nada eu ficar com raiva... Só eu que saio perdendo... Que nem aquela vez que eu se dependurei lá no teto... Depois fiquei com vergonha da dona P. Não queria que ela visse aquilo. Se tivesse se acalmado não tinha feito.

T: O que você sente falando disso? (SRE)

S10: Vergonha... arrependido... não queria ter feito né... se o tempo voltasse eu não fazia...

Observando-se os escores das práticas educativas dos pais de S10 (Tabela 15) fica claro que eram os pais pareciam ter desempenhado bem a função educativa. De acordo com a pontuação total ambos encontravam-se na pontuação indicativa de "Estilo Parental Regular, porém abaixo da média"(Gomide, 2006). Por que então S10 apresentava algumas características semelhantes aos demais infratores? 
Tabela 15. Práticas educativas dos cuidadores de S10 avaliadas através do Inventário de Estilos Parentais.

\begin{tabular}{|c|c|c|c|c|c|c|c|c|}
\hline IEP S10 & 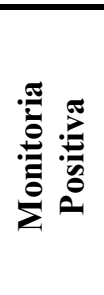 & 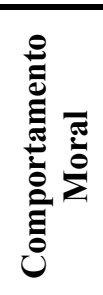 & 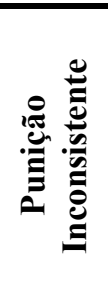 & 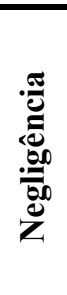 & 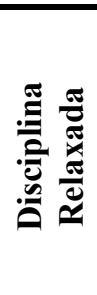 & 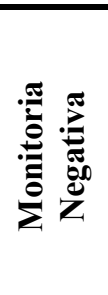 & 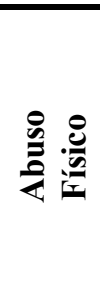 & $\overline{\text { IEP }}$ \\
\hline IEP Materno & 12 & 11 & 4 & 2 & 3 & 8 & 2 & 4 \\
\hline IEP Paterno & 7 & 10 & 1 & 1 & 2 & 8 & 1 & 4 \\
\hline
\end{tabular}

S10 não apresentava em sua história de vida os mesmos fatores de risco observados nos demais jovens, tais como: pais anti-sociais, alcoolismo e dependência química dos pais, avós inábeis e fatores ambientais estressores (Patterson et al., 1992). Mas possuía sim temperamento abrasivo (Ross, 1979). Analisando estas características de temperamento expressas através de comportamentos do adolescente é possível sistematizar a ocorrência dos seguintes comportamentos:

- Padrão recorrente de comportamento negativista, desafiador, desobediente e hostil para com figuras de autoridade

- Perda de paciência

- Discutir com adultos

- Desafiar ativamente ou recusar-se a obedecer a solicitações ou regras dos adultos Fazer propositalmente coisas que aborrecem outras pessoas

- Responsabilizar outras pessoas por seus próprios erros ou mau comportamento

- Ser suscetível ou facilmente aborrecido pelos outros

- Mostrar-se enraivecido e ressentido

- Ser rancoroso ou vingativo.

Todos os comportamentos citados acima fazem parte do critério A para diagnóstico do Transtorno Desafiador Opositivo - F91.3 (DSM IV - TR), e todos eles eram marcadamente presentes no repertório de S10. Quando estes comportamentos acarretam prejuízos significativos nos âmbitos social, acadêmico ou ocupacional e 
ocorrem com freqüência superior à típica para indivíduos na mesma faixa de desenvolvimento, tem-se atendido o critério B para o diagnóstico do mesmo quadro F91.3. O terceiro critério, C, enfatiza que este quadro deve excluir os padrões de comportamento encontrados nos transtornos de conduta (TC - F91.8) (DSM-IV-TR, 2002) e anti-social de personalidade (TPAS - F 60.2) (DSM-IV-TR, 2002). S10 não possuía alguns comportamentos necessários ao diagnóstico de $\mathrm{TC}$, assim como não apresentava os seguintes comportamentos: manipulação dos outros para obter satisfação, ausência de culpa e remorso, mentira patológica, promiscuidade sexual, dentre outros necessários para o diagnóstico de TPAS. S10 somente cometeu um ato infracional grave, no mais era considerado uma criança de temperamento difícil e adolescente rebelde, porém respeitava seus pais e irmãos mais velhos, trabalhava e não violava seriamente regras sociais ou familiares. Outro ponto importante é que este padrão comportamental descrito pelo diagnóstico de Dasafiador Opositivo é anterior aos 8 anos de idade, ou seja, raramente se apresenta na adolescência. S10 sempre foi considerado uma criança difícil e seu padrão comportamental "teimoso" é descrito pelos pais como existindo "desde sempre" (SIC).

"Os comportamentos negativistas ou desafiadores são expressados por teimosia persistente, resistência a ordens e relutância em comprometerse, ceder ou negociar com adultos ou seus pares. O desafio também pode incluir testagem deliberada ou persistente dos limites, geralmente ignorando ordens, discutindo (...) a hostilidade pode ser dirigida a adultos ou a seus pares, sendo demonstrada ao incomodar deliberadamente ou agredir verbalmente outras pessoas. (...) Em geral, os indivíduos com este transtorno não se consideram oposicionais ou desafiadores, mas justificam seu comportamento como uma resposta a exigências ou circunstâncias irracionais.”(DSM IV-TR, 2002, pág 388) 


\section{S11: O LÍDER}

O participante S11 teve seu caso discutido no projeto deste trabalho apresentado para a banca de qualificação, sendo o Caso Modelo deste trabalho. Seus dados foram computados para análise global compreendendo todos os atendimentos, porém a análise individual do caso será inserida integralmente como foi apresentada no projeto.

\section{Estudo de Caso Modelo}

\section{Dados de Identificação}

Nome: G.

Ano de nascimento: 1985

Idade: 21 anos, tinha 17 anos ao entrar no sistema.

Estado civil: solteiro

Residiu com os pais biológicos até os quatro anos, após morou com o pai e com a madrasta, com a avó paterna, com a avó materna, com a irmã, com a mãe biológica, novamente com a irmã e quando retornou para casa da mãe biológica ficou pouco em casa, alugou uma casa próxima e nesta época é que foi preso. Ou seja, pode-se dizer que G. "residiu" em nove locais diferentes.

\section{Histórico Familiar}

Filho mais novo de uma prole de cinco, os pais de G. separaram-se quando ele tinha quatro anos. O pai era caminhoneiro e a mãe começou a trabalhar como diarista quando se separou. A relação dos pais era complicada, o pai bebia e agredia fisicamente a esposa e os filhos. A separação foi precipitada pelo pai que trouxe outra mulher para morar em casa, exigindo que a mãe de G. saísse de casa. A madrasta 
era violenta e castigava fisicamente os enteados, principalmente G. e as irmãs mais novas. A mãe de G. teve outro companheiro, com quem G. mantinha uma relação afetiva, considerando o mesmo como pai, porém este senhor faleceu precocemente de câncer. Depois deste relacionamento a mãe de G. não teve nenhum outro relacionamento estável.

O pai biológico faleceu atropelado quando G. tinha aproximadamente seis anos de idade. A irmã relata que estavam com ele indo para Santa Catarina, de caminhão. Parados no acostamento enquanto o pai verificava freios e pneus, veio uma caminhonete no sentido contrário, perdeu a direção e atropelou o pai. O jovem refere ter sofrido mais a morte do padrasto, com quem se relacionava melhor e conviveu mais.

O irmão mais velho é do sexo masculino com $30 \operatorname{anos}^{17}$, sendo seguido de uma moça com 27 anos, outro rapaz de 26 anos e mais uma moça com 22 anos. Exceto a mais nova, todos são casados e têm filhos. O irmão mais moço já teve quatro companheiras e tem um filho de cada relacionamento, o mais velho possui companheira estável e tem três filhos e a irmã mais velha possui companheiro estável e um filho de 13 anos, com quem G. passou parte da infância. O irmão mais velho segundo relatos de G. e de sua mãe, também apresentou condutas infracionais, inclusive perdendo seu último emprego devido a um fato que não quiseram explicar, mas nunca foi preso.

Não há informações sobre a profissão dos avós paternos, apenas que a avó paterna era violenta e brigava fisicamente com o marido e com seus próprios irmãos, os tios-avôs de G., que por sua vez têm históricos infracionais graves, ligados à tentativa de homicídio. Moravam juntos, avó e tios-avôs, todos bebiam e quando G. morou com esta avó os tios privavam-no de alimento que a mãe de G. fornecia.

\footnotetext{
${ }^{17}$ As idades citadas referem-se à época do início da psicoterapia.
} 
A avó materna tinha uma vida sexual marcadamente promíscua, sendo que prostituía a mãe de G. na infância, esta não sabe quem foi seu pai biológico. A mãe de G. sofreu inúmeros episódios de abuso sexual e físico durante a infância, adolescência e também na vida adulta. Quando a avó materna de G. casou-se com um agricultor, os abusos continuaram dentro de casa, fazendo com que aos 15 anos a jovem saísse de casa. Apesar da história de abuso, a mãe de G. nunca cometeu atos infracionais.

Não há informações sobre os dados de escolaridade do pai; a mãe sabe escrever o nome e lê o suficiente para se locomover e fazer compras. Dos irmãos, apenas as mulheres concluíram o segundo grau.

$\mathrm{Na}$ ocasião de seu desinternamento a mãe trabalhava duas vezes por semana como diarista, o irmão mais velho estava desempregado, vivia de bicos e tinha problemas com bebida, a irmã mais velha trabalhava em uma academia de ginástica como recepcionista e professora substituta, o outro irmão trabalhava em uma fábrica e a irmã mais nova, estava desempregada há três anos. Ela procurava emprego na área industrial desde que tinha sido afastada devido a lesão por esforços repetitivos, mas era ela a responsável pela administração e cuidado da casa da irmã, com quem mora. Quando G. voltou para a casa da irmã, ele e a irmã mais nova arrumaram juntos empregos numa indústria local, na qual a irmã continua.O irmão mais velho, arrendou um caminhão e chamou G. para trabalhar com ele.

Como novas ameaças frequentemente surgiam (algumas inclusive se tornando reais, tais como invasão de domicilio, agressão física a membros da família) G. aceitou a proposta do irmão. Relatou ter ficado animado com a possibilidade de aprender a dirigir o caminhão e tirar carteira de motorista, podendo fazer deste seu ofício. Durante três meses de viagem tudo estava muito bem, mas quando chegaram em um estado do nordeste do país, o irmão disse que tinha que ir para São Paulo resolver 
uns problemas com o dono de uma carga e pediu os documentos de G. para dar início do procedimento de tirar a carteira de motorista. Mesmo achando estranho ele deu os documentos e não se surpreendeu quando o irmão disse que tinha tentado comprar uma carteira de motorista pra ele, disse que sabia que o irmão estava aprontando alguma. Porém, o envolvimento do irmão com alguma contravenção devia de fato ser maior, porque dias depois ele ligou de um hospital: tinha apanhado muito durante um "assalto" no qual levaram apenas os documentos de G. e dinheiro. Nesta época G. ligou pedindo ajuda e orientação para a terapeuta, pois estava sozinho e sem documentos em um estado desconhecido para ele.

\section{Histórico Acadêmico}

Ingressou na escola com aproximadamente oito anos, relata sempre ter tido dificuldades para entender as coisas e prestar atenção. Passou por três escolas até a quarta série, devido aos problemas familiares e constantes mudanças de moradia.

$\mathrm{Na}$ quinta série, já em outra escola (a quarta), com as dificuldades de comportamento e o atraso escolar, a irmã muda G. de escola para que ele pudesse realizar um curso supletivo, que não foi concluído. G. brigou com a irmã, com quem morava, voltou a residir com a mãe e evade-se da escola, retornando aos estudos no Educandário quando internado.

\section{Histórico Infracional}

G. relata ter cometido furtos e roubos para comprar drogas, roupas e bebida. Certa vez confundiram-no com um ladrão de automóveis e ele passou 24 horas na delegacia. Outra vez sua mãe chamou a polícia porque G. estava com uma arma em casa e traficantes rondavam a casa da mãe. G. foi encaminhado para o regime de semiliberdade, do qual fugiu após dois meses, retornou após um mês e cumpriu mais três meses de medida. 
A medida pela qual estava respondendo quando iniciou da psicoterapia devia-se a um assalto, no qual G. teria atirado durante a fuga, ferindo uma pessoa. A princípio, ele negava que isso fosse verdadeiro. Enquanto cumpria a medida em regime de internato do Educandário São Francisco, G. teve várias ocorrências disciplinares (brigas, uso de drogas, abuso sexual), todas as quais nega, dizendo que era perseguido pelos educadores. Na ocasião da rebelião que culminou com a transferência de G. para a uma Penitenciária de segurança máxima e depois para a Unidade de Alto-risco, onde ingressou no programa. G. foi acusado de ser um dos líderes da rebelião na qual sete adolescentes foram mortos.

\section{Análise das contingências de instalação e manutenção de comportamento infrator:}

G. teve uma infância marcada por abandonos, violência, perdas e fracasso escolar. No início da adolescência inicia o uso de drogas. Com a dependência química inicia-se o histórico infracional. G. passa a realizar assaltos e comprar drogas, cujo uso o faz sentirse bem e relaxado. G. abandona definitivamente a escola e se torna agressivo com os familiares. Desta forma consegue eliminar algumas perdas e o fracasso escolar. A moradia e roupa são então obtidas por dinheiro de assaltos. Passou a ser conhecido e respeitado no meio infrator e sentia que possuía um lugar de destaque naquele grupo, tanto que não lhe faltavam namoradas e amigos. Quando o dinheiro acabava ele cometia assaltos. Como conseqüência de um assalto, G. foi internado para cumprir medida socioeducativa em meio fechado. Já no educandário G. passa a ser solicitado a obedecer aos mandos de um outro adolescente, monitor de seu alojamento., Descontente com a forma como estava sendo tratado, G. agride fisicamente o rapaz; recebe uma detenção em isolamento e quando volta para o convívio com os demais passa a ser respeitado e em poucas semanas se torna o novo monitor de toda a ala o que lhe confere além de status a possibilidade de comercializar café e cigarro nos alojamentos. Até mesmo 
funcionários do local compravam café e cigarro dele, o que aumentava sua sensação de poder e segurança em um local considerado perigoso até mesmo pelos internos.

Início da psicoterapia: 16/03/2005

Número de sessões individuais: 28

Número de sessões com o grupo familiar: 06

Sessões individuais com membros da família: 07

Data de desinternamento: 07/ 06/ 2005 - juíza deu o parecer, G. ainda passou a noite na Unidade

08/06/2005 - G. saiu da Unidade e foi para a nova residência. Fazendo parte de um Programa de Egressos, ele recebeu acompanhamento da psicoterapeuta nas atividades deste dia, desde a confecção de documentos até a mudança para a nova casa. A mãe acompanhou parte das atividades.

Situação acadêmica ao final da psicoterapia: matriculado em curso supletivo para concluir o ensino fundamental. Tinha dificuldades para estudar e recebia reforço escolar de voluntários nas matérias de português, matemática, inglês e ciências. Por telefone, contou para psicoterapeuta que estava estudando novamente, concluindo de fato a última etapa do ensino fundamental, para no próximo semestre iniciar o ensino médio ou fazer um curso técnico na área de mecânica.

Situação profissional na época da qualificação do projeto de pesquisa desta tese: após duas entrevistas de emprego mal-sucedidas, G. passou por treino específico para entrevista em sua psicoterapia e no dia 19/07/2005 fez nova entrevista para uma 
indústria de seleção de alumínio para reciclagem e no dia 20/07/2005 recebeu o resultado positivo indicando que receberia treinamento e começou a trabalhar. Neste emprego, apesar de não ser em sua cidade de origem, deparou-se com indivíduos que conhecia na época em que fazia parte de gangues. Este fato causou-lhe preocupação e nervosismo, e mais tarde, de fato, trouxe-lhe problemas concretos através de ameaças e agressão física por parte de membros de gangues inimigas à qual havia feito parte. Saiu deste trabalho na época do ingresso no Programa de Proteção a Testemunhas, e quando deixou este programa foi trabalhar em uma outra empresa de porte industrial, na qual permaneceu por três meses trabalhando diariamente das 10:00 às 22:00.

No final de 2007, ainda morando em outro estado a fim de preservar sua vida, G. não tinha emprego fixo, fazia bicos como pedreiro, pintor, jardineiro.

\section{Resumo das sessões ${ }^{18}$ :}

$16 / 03$

$\mathrm{Na}$ primeira sessão a psicoterapeuta apresentou-se ao adolescente e explicou seus objetivos como voluntária e pesquisadora. Explicou as diferenças entre o trabalho que estava propondo, daquele realizado pelas psicólogas do Estado que o adolescente já conhecia.

Procedeu-se à coleta dos dados de identificação do adolescente, de seus familiares, situação escolar, laboral, dados referentes ao internamento atual e anteriores.

G. descreveu a rotina na Unidade e contou que terminou leitura do livro Gulliver.

Relata que foi lhe dado um grão de feijão em um copinho plástico com um algodão para que ele cuidasse e observasse a transformação do grão em planta. Contou que estava cuidando do feijão: "Tem que cuidar... tem que cuidar, né? Se deram pra mim tem que cuidar!"

Quando perguntado sobre amizades deixa clara a dificuldade que possui de confiar nos outros: "Não, amigo, amigo de verdade acho que é difícil o cara ter amigo de verdade".

\footnotetext{
${ }^{18}$ Há o registro de vinte e sete sessões, porém somente estão resumidas sessões relevantes para análise.
} 
Falou sobre seu papel de monitor no educandário e a possível ligação disso com o fato de ser sido acusado de liderar a rebelião. Quando indagado sobre o gosto por esportes, falou de sua habilidade no futebol.

Parte do próprio adolescente contar sobre seu histórico infracional e a relação que julga ter com o uso de drogas. Iniciou o uso de maconha e álcool por volta dos 9 anos de idade.

No final da sessão foi feito o contrato de sigilo e de psicoterapia, bem como explicou-se o termo de consentimento livre e esclarecido da pesquisa.

23/03

Iniciou-se a sessão com a aplicação do IEP materno. Devido ao comportamento hostil do adolescente expresso verbalmente para a psicoterapeuta, ela reassegurou a confidencialidade do processo e colocou-se à disposição para esclarecer as dúvidas que o jovem pudesse ter.

Histórico infracional.

Uso de drogas.

Rebelião no educandário.

Psicoterapeuta demonstra verbalmente aceitação.

$31 / 03$

Psicoterapeuta explica que não fará relatórios.

Explica novamente processo terapêutico.

G. estava mais calado que nas sessões anteriores.

Vida escolar.

Timidez.

Brigava muito na escola. "Não levava desaforo pra casa."

Continuação de levantamento de dados de história de vida e saúde.

Conta que tem tido dores de cabeça. O início coincide com o início da psicoterapia, quinze dias atrás.

Pai biológico era alcoolista.

Situação da primeira "prisão" e do assalto pelo qual está aqui.

Gangue e liderança.

Trabalho.

Mentira.

Combinado sobre a presença da psicoterapeuta na visita com a mãe de G.; ele acha que a mãe não virá. 


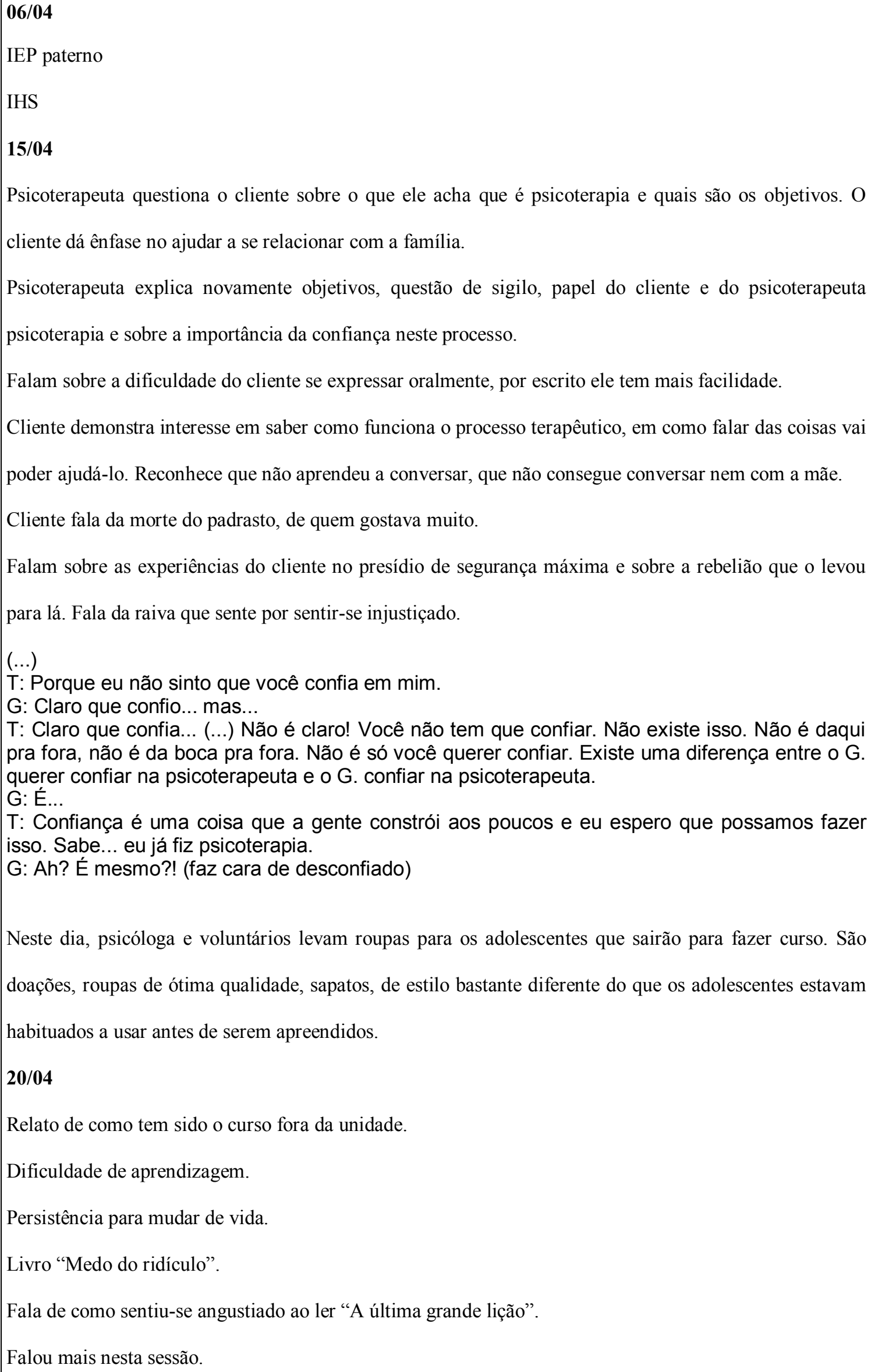


Discutimos a dificuldade de reconhecer e expressar sentimentos.

Situação da carta inadequada para Dra. Paula. Fica tenso, sai apenas despedindo-se verbalmente da psicoterapeuta (geralmente a despedida se dá com um aperto de mão).

$27 / 04$

Cliente vem com a expressão facial demonstrando desagrado. A psicoterapeuta o questiona e ele expõe como se sentiu sobre a situação da carta no final da sessão anterior. A psicoterapeuta demonstra aceitação e explora o que o cliente está sentindo. A sessão gira em torno de como lidar com a raiva, com a injustiça e com o conceito de amizade.

04/05 - Nesta sessão há indícios de que se forma o vínculo terapêutico. Acontece uma revelação importante do cliente, sugerindo que ele passa a confiar na psicoterapeuta.

Fala sobre o gosto pelo futebol e que queria ser jogador.

Psicoterapeuta fala sobre a situação da semana anterior quando a PM entrou na unidade e o cliente apanhou injustamente e expressa desacordo com o fato ocorrido, além de se colocar no lugar do cliente dizendo que a situação deve ter sido muito difícil.

Cliente conta a situação e como sua reação foi diferente das outras vezes. A psicoterapeuta questiona como é que desta vez ele se controlou. O cliente descreveu as contingências que controlaram seu comportamento: pensar que poderia perder tudo o que já havia conseguido, olhar para o guarda e pensar que ele é autoridade e que não adianta reagir naquele momento.

Falam sobre a relação do cliente com a mãe. $O$ assunto parece ser aversivo, e o cliente muda o tema.

Falam sobre os outros psicólogos com quem o cliente já teve contato, pois parece não ter feito vínculo com nenhum deles.

Falam sobre o desinternamento do cliente, que está próximo, e suas perspectivas de futuro (trabalho, moradia, etc.).

T - A sua pasta eu não posso pegar para você ler. Mas eu anotei algumas coisas. (...) Você me disse que nunca tinha feito psicoterapia, mas lá vi alguns dos relatórios, as observações da K. (técnica responsável), (...) ela dizia que você não aceitava ajuda. (...) Então não fez mesmo, não é? Porque ela queria fazer psicoterapia, você não fez.

C: Quem que ia fazer?

T - A K. Está escrito lá que aquilo era psicoterapia.

C: Ela não falo nada.

T - Lá estava escrito que era psicoterapia. (...)

C: Ela não falo nada pra mim.

T - É, tinha lá: "início da psicoterapia". Depois mudou, né? Ela foi embora. E o que aconteceu?

C: Ela foi embora. Daí ficou a T. Depois (...) daí foi o C.

$\mathrm{T}-($...) É um baixinho?

C: É.

$\mathrm{T}$ - Você gostava dele? 
C: Gostar porque?

T - Assim... achava o cara legal?

C: Fiquei poucos dias, ele me atendeu duas vezes só.

T - Você não chegou a conhecê-lo direito. E a K., ela te ajudava a conversar legal?

C: Eu não sabia conversar nada.

T - Não?

C: Eu pelo menos acho que não. Meu Deus! Entrei, nunca vi a mulher na minha vida, no primeiro dia ela chegou pra mim e disse: "Olhe só, você vai ficar três anos." Quer que eu olhe pra cara dela e dê risada?

T - Como é que é que foi? Ela disse que você ia ficar 3 anos aqui?

C: Hã-hã. Que é que eu vou fazer? Vou dar risada agora? Pfffff..... tá bom...

$\mathrm{T}-\mathrm{E}$ foi lá que encaminharam a tua mãe para fazer psicoterapia? Foram eles que falaram para sua mãe que era bom que ela fizesse, que ela tava muito deprimida. Ela sempre foi assim?

C: O que?

T - Deprimida?

C: Hã-hã.

T - Antes de ela se separar do teu pai, ela já era assim?

C: Não sei.

T - Ou você acha que foi depois da separação.

C: Não lembro.

T - Você era muito pequenininho, não é mesmo?

C: Hã-hã.

(...)

T - Minha proposta é te acompanhar mesmo quando você sair daqui, o que vai depender de você. Eu não ficaria satisfeita com meu trabalho se a tua avaliação fosse de que eu não sei te escutar, ou que a psicoterapia não serve pra nada. Acho até que a gente já conversou sobre isso um pouquinho, não é?

C: Não tenho certeza... mas, ela falou! (referindo-se à técnica que tentou fazer atendimento com ele.)

T - Mas então eu estou te perguntando: você acha que essa forma que eu te abordo é adequada? Você acha que eu pergunto demais ou pergunto coisas que não tem nada haver?

C: Não, eu não falei isso não. Só não consigo falar! Não sei, (...) sei lá.

$T$ - Sabe que eu acho que você, naquele dia da visita da tua mãe, falou legal! E a psicoterapia de família é bem daquele jeito... Sabe G., um dos objetivos é mostrar para todos da família que não existe um culpado, que ninguém desmonta uma família sozinho. Geralmente quando tem um comportamento inadequado de uma criança, de um adolescente, de um pré-adolescente, isto acontece porque a família já não está funcionando legal... Quer dizer, não é culpa dele, sua, Por exemplo, naqueles momentos que a tua mãe disse: "Não! Mas ele nunca parou em casa, não tinha como segurar!" E eu disse: "Quer dizer, ele nunca teve casa. Uma casa de verdade!" Não sei se você concorda comigo... Você nunca teve um vínculo forte, um lugarzinho teu, você ia muito de um lugar para o outro, casa do pai, casa da avó, cada da irmã. (...) E daí seria interessante ajudar a tua mãe a perceber que também não é culpa dela. Ela não soube lidar com algumas situações (...) Não tinha como ela te dar uma casa, um lar para morar quando ela se separou do teu pai. Não adianta ela se sentir culpada também. Não é fácil educar filhos.

(...)

T - Você tem vontade de ter filhos?

C: De ter filho?

$T-\dot{E}$.

C: Não.

T - Nunca teve (vontade)?

C: Ah! Pra falar a verdade acho que tenho um piá.

T - Você acha que tem um filho?

C: Eu acho. Pelo menos acho que é meu, né. Não tenho certeza.

$T-E$ filho de quem?

C: De uma guria.

T - Faz quanto tempo?

(...) 
O cliente acha que a sessão passou muito rápido.

06/05 - Visita da mãe do cliente na unidade de internamento e primeira entrevista da mãe com a psicoterapeuta.

Mãe conta brevemente de como teve uma vida difícil com o pai de G., de seus problemas com a depressão e de como sofreu com o comportamento anti-social do filho. Conta como o ex-marido e o último companheiro morreram. Fala da psicoterapia que fez em uma clínica escola, por causa da depressão na época em que o filho foi internado no educandário. A mãe aceita fazer parte do processo terapêutico.

\section{$18 / 05$}

Sessão com G. e sua mãe na unidade de internamento.

A mãe relata infância do filho e histórico infracional sob seu ponto de vista.

20/05 (Atividade de Filme (Redenção) em grupo)

31/05 - Sessão com a mãe no consultório (2 horas)

Mãe conta sobre a própria infância. Sofreu abuso físico, psicológico e sexual, muitas vezes pela própria mãe e padrasto. Já adulta foi espancada e abusada sexualmente pelo próprio marido.

$1 \%$

Neste dia o adolescente apresenta vários comportamentos de hostilidade, pois está descontente com o que considera ser "demora" para sair da unidade.

O adolescente mais uma vez culpa os outros pelas conseqüências dos próprios atos.

A terapeuta acolhe e descreve contingências relacionadas ao que ele chama "demora", exemplificando atividades que são realizadas, como são realizadas, quem as realiza, e que estão relacionadas com o desinternamento de uma instituição. Mostra ainda especialmente no caso dele quem são as pessoas envolvidas no processo, o que estão fazendo e como estão fazendo.

Grande parte da sessão a terapeuta fala sobre tentativas de encontrar uma nova residência para G. G. escuta de cabeça de baixa e fala pouquíssimo, prolongando vários momentos de silêncio.

Quando diz que não quer ajuda e que vai morar com um irmão, a terapeuta se interessa pela possibilidade e pede que ele lhe dê mais informações propondo-se a ajudar. A partir deste momento G. adota uma postura relaxada, sem hostilidade, fala de seus sentimentos em relação à saída e todos os assuntos aí envolvidos. Pela primeira vez fala que sente medo, revolta quando the pedem mais paciência, quando 
acha que estão mentindo pra ele. Diz que não agüenta mais esse lugar. Neste momento sua expressão de angústia é nítida.

São trabalhadas diversas situações de resolução de problemas relacionadas aos temas: onde morar, continuidade do curso, estudo, custo de vida, entre outros.

Revela que aceitou o curso apenas para não ficar na cela, que não gosta do curso e que se sente mal no curso com as pessoas. Sente-se diferente das pessoas de lá.

Fala-se de empatia. A terapeuta explica o que é e dá exemplos de situações em que ele se colocou no lugar dos outros. Novamente G. se cala, não olha para a terapeuta e não interage com ela (que continua falando sobre como as pessoas se sentem, incluindo exemplos de situações nas quais G. não falou o que estava sentindo, mas seus comportamentos podiam estar indicando o que estava acontecendo com ele).

Quando a terapeuta usa um exemplo do filme Redenção, G. volta a interagir dizendo que não prestou atenção no filme. Por vários minutos a terapeuta dá exemplos de como G. se comportou, relacionando-os com cenas do filme. G. permanece calado. Na hora de ir embora, sorri e aperta a mão da terapeuta três vezes, dá risada e diz que não queria que acabasse.

A psicoterapeuta recebe um pedido dos educadores e professores que atenda G. novamente nesta semana porque ele está muito ansioso com a data de sua liberação. Os profissionais se mostraram preocupados com reações que o jovem pudesse ter que prejudicassem a si mesmo. Também apreensiva com a situação a psicoterapeuta atende novamente o adolescente.

03/06

Sessão se realizou no gramado da instituição, o dia estava ensolarado e não havia sala disponível para o atendimento. Duração aproximada de 30 minutos.

Falam sobre o curso, sobre a dificuldade das pessoas aceitarem de onde ele veio (educandário) e do que pode ser dito para não se expor e nem mentir.

Cliente ansioso com sua saída, pois parece que as coisas não andam como ele gostaria e na velocidade que ele gostaria.

05/06 (Atividade Externa de grupo)

Almoço no restaurante Madalosso.

Visita ao Museu Oscar Niemeyer.

Ida ao teatro assistir à peça Gatos.

07/06 - Sessão com mãe no consultório (2 horas) 
Mãe continua contando sobre a própria infância e abusos sofridos. Se emociona muito, chora e diz que acha que isso a fez ser dura com os filhos.

\section{SAÍDA DA UNIDADE DE INTERNAMENTO}

08/06 - Saída de G. da unidade de internamento.

A psicóloga conseguiu uma vaga para o adolescente morar em uma casa de estudantes no centro da cidade, facilitando desta forma a continuidade do processo e a permanência no programa.

Foi realizado um breve atendimento para que o adolescente pudesse planejar

14/06 (Vaso quebrado)

O objetivo desta sessão era de fazer com que o cliente pudesse discriminar relações entre seus comportamentos atuais, inclusive suas dificuldades, e situações de sua história de vida. Foram discutidas possibilidades de reconstrução de experiências utilizando a metáfora do vaso que quebrou e que pode ser colado. O vaso foi colado e suas características foram discutidas.

14/06 - Sessão mãe e filho no consultório

Sessão na qual a psicoterapeuta mostra para a mãe e dá modelo de como é a prática educativa de monitoria positiva. A mãe duvida do filho, não consegue verbalizar apoio e esta situação que gera raiva no filho é trabalhada.

19/06 (Atividade Externa de grupo - Teatro e aniversário do Cristiano)

Esta foi a primeira atividade externa em grupo depois que G. saiu da unidade. Foi possível observar comportamentos diferentes de G. em relação aos meninos que ainda estão internados: ficou mais distante deles, falou menos e expressou afeto através de gestos, por exemplo, abraçando os demais.

Após o término da atividade contou para a psicoterapeuta que soube que no bairro da irmã diziam que sua prisão havia sido por estupro. Ele estava muito revoltado com isso. Foi explorado como ele estava se sentindo e quais as opções não-infratoras para resolver esta situação. Ele optou por não mexer com o assunto, dizendo que apenas esclarecia isto com seus familiares próximos.

\section{3/06}

A psicoterapeuta faz um combinado com o cliente sobre o número de ligações telefônicas que o mesmo tem feito. Fica estabelecido que é no horário de psicoterapia que as orientações serão feitas. O objetivo desta intervenção foi mostrar para o cliente que as faltas à psicoterapia interferem negativamente no processo e fazem com que ele ligue muito solicitando orientações que deveriam ser obtidas durante as sessões. 
O IHS é aplicado novamente.

02/07 Sessão com mãe, filho (cliente) e irmã mais velha

15/07 Nesta sessão foi realizado um ensaio comportamental de uma entrevista de emprego, pois G. relatou seu desconforto nestas situações e percebeu que tem se esquivado destas situações, reconhecendo a importância de que aprenda a enfrentar a situação para conseguir um emprego do qual goste e tenha uma boa remuneração.

A terapeuta retoma a sessão passada na qual G. trouxe a namorada. Ele concorda que este namoro tem feito bem para ele. Namoram escondidos, pois os pais ela não aceitam o passado dele, e ela ainda não quer que ele fale pessoalmente com os pais dela.

Mostrando como não se pode mudar o que passou, mas que podemos construir o futuro, a terapeuta insiste na continuidade dos estudos, perguntando se G. foi marcar a data da avaliação na escola. Ele responde que não e então fala sobre a dificuldade que tem em matemática. Perguntando sobre o aproveitamento que tem tido nas aulas de reforço com uma voluntária, ele diz que não gosta do jeito que ela ensina, que ela é muito rápida e que ele não está aproveitando nada, pois está sendo um momento no qual se irrita e não consegue pedir para ela falar diferente.

G. conta que foi passar o final de semana na casa da mãe e que estava ajudando no jardim quando foi visto por um rapaz que mora próximo e é da polícia, mas também é um conhecido transgressor no local, ele protege traficantes. G. teve problemas com ele no passado, pois não admitia ter que "pagar pedágio pra pilantra" e numa discussão o tal rapaz disse que G. tava marcado. Poucos minutos depois de ter visto G. o rapaz saiu de carro e voltou com mais três rapazes. Estacionaram, desceram e ficaram olhando na direção de G. por mais de uma hora. Conversando com a terapeuta G. concluiu que é melhor não ir na casa da mãe por uns tempos.

\section{7/07 - Sessão-extra NÃO FOI GRAVADA}

\section{Revelação sobre Rebelião}

G. telefona para a terapeuta, que estava de férias, e pede para falar com ela. Ao contrário das outras vezes não diz que é urgente ou importante, mas tem a voz embargada. A terapeuta então marca o atendimento para dali uma hora. G. parece cansado, está com os olhos inchados e assim que entra na sala começa a chorar violentamente dizendo que podia ter evitado as mortes da rebelião e que não o fez.

Senta-se no chão e com a cabeça baixa entre as pernas e coberta com os braços ele relata detalhadamente a rebelião. A terapeuta, que se sentou ao lado de G., colocou uma mão sobre o ombro de G. e chora 
também, mas seu choro parece não ser percebido pelo cliente durante o relato. $\mathrm{O}$ relato durou mais de uma hora, na qual ambos permaneceram sentados no chão, G. chorou ininterruptamente, gritou e algumas vezes tentou dar socos na própria cabeça (mas foi impedido pela terapeuta).

$\mathrm{Na}$ medida em que o relato foi se esgotando a terapeuta passou a interagir verbalmente, facilitando a verbalização dos sentimentos de arrependimento, vergonha, raiva e tristeza. G. pediu para que ela explicasse porque ele tinha sido daquele jeito um dia, porque ele não era mais a mesma pessoa, "aquele era um monstro, por que eu era um monstro?" Somando o tempo transcorrido na revelação e mais a intervenção propriamente dita, foram aproximadamente três horas e meia de sessão.

Nos dias que se seguiram foram realizados contatos telefônicos breves para acompanhar G., que arruma emprego. No dia 30 de julho ele solicita uma "sessão rapidinha", pois acha ruim falar no telefone. Como a terapeuta está no consultório para atender outros clientes, ela agenda trinta minutos para atender G.

30/07 - Sessão com duração aproximada de 20 minutos.

Cliente conta que há possibilidade de ir morar com a irmã, já que arrumou um emprego e que esta era uma condição imposta pela mesma.

Nesta sessão a psicoterapeuta conversa com o cliente sobre como ele e a mãe têm dificuldades para se expressar: ambos não reconhecem afeto um no outro. O cliente acha que deve ser pela pouca convivência. Escrevem carta de agradecimento para o "padrinho" que pagou estes meses de moradia e para o responsável da casa do estudante onde o cliente morou.

Cliente não trouxe tarefa solicitada: iniciar sua autobiografia. Diz que esqueceu de fazer.

03/08 - Nova aplicação do IHS

17/08 - Psicoterapeuta questiona sobre envolvimento com crime organizado, pois de acordo com informações obtidas na unidade de internamento, caso houvesse envolvimento a data limite para o retorno às atividades infratoras estaria se aproximando. A psicoterapeuta assegura apoio e garante haver solução apoiada pela lei para resolver este tipo de problema.

21/08 - G. saí da casa da irmã, pois está sendo ameaçado.

22 de Agosto - Procura psicoterapeuta. Está muito nervoso, conta que está sendo ameaçado e que terá que fugir. A psicoterapeuta entra em contato com a coordenadora do programa que sugere a inserção do adolescente em um Programa de Proteção. O cliente aceita. 
O participante 11 (S11) passou por 23 sessões de psicoterapia, das quais

9 foram analisadas.

A Figura 41 abaixo mostra na distribuição linear das sessões, quais as analisadas.

\begin{tabular}{|l|l|l|l|l|l|l|l|l|l|l|l|l|l|l|l|l|l|l|l|l|l|l|l|}
\hline Sessões & 1 & 2 & 3 & 4 & 5 & 6 & 7 & 8 & 9 & 10 & 11 & 12 & 13 & 14 & 15 & 16 & 17 & 18 & 19 & 20 & 21 & 22 & 23 \\
\hline Analisadas & & & & & & & & & & & & & & & & & & & & & & \\
\hline
\end{tabular}

Figura 41. Sessões de psicoterapia analisadas do participante S11.

Tabela 16. Práticas educativas dos cuidadores de S11 avaliadas através do Inventário de Estilos Parentais.

\begin{tabular}{|c|c|c|c|c|c|c|c|c|}
\hline IEP S11 & 苞 & 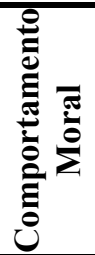 & 兽 & 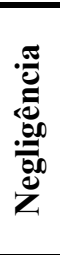 & 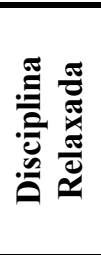 & 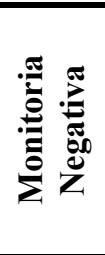 & 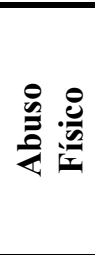 & IEP \\
\hline IEP Materno & 3 & 4 & 5 & 9 & 6 & 5 & 11 & -29 \\
\hline IEP Padrasto & 3 & 1 & 0 & 5 & 3 & 1 & 0 & -5 \\
\hline
\end{tabular}

As práticas educativas dos cuidadores de G. evidenciam o que é dito na literatura sobre infratores, ou seja, o comportamento criminoso acaba por fazer parte do repertório de crianças e adolescentes que não tiveram práticas educativas positivas em sua educação. Conforme se observa na Tabela 16 o IEP materno revela a grave situação: em um valor máximo de 12 pontos para cada prática negativa, a mãe de G. preenche 10 pontos em Negligência e 11 pontos em Abuso Físico. Nas práticas positivas, onde seria ideal aproximar-se dos 12 pontos, ela tem 3 pontos para Monitoria Positiva e 3 pontos para o Comportamento Moral.

G. relatava ter sentindo mais afeto pelo padrasto do que pelo pai (que abusou física e psicologicamente dele). Este afeto pelo padrasto explica-se devido ao fato de que embora o mesmo não apresentasse práticas positivas, também não apresentava as negativas, o que para o adolescente já era muito bom. Esperava-se obter através do IEP do padrasto níveis mais altos de práticas educativas positivas, o que não ocorreu (Monitoria Positiva $=3$ e Comportamento Moral $=1$ ). Porém, dentre as práticas 
negativas a pontuação é inferior se comparada à da mãe, indicando uma relação menos aversiva. O padrasto era menos Negligente (5 pontos) e não cometia nenhum tipo de abuso físico.

Na Figura 42 é possível notar que a concentração de práticas positiva (Monitoria Positiva e Comportamento Moral) é menor do que as negativas, que se encontram no lado direito do gráfico, referindo-se às práticas maternas e do padrasto.

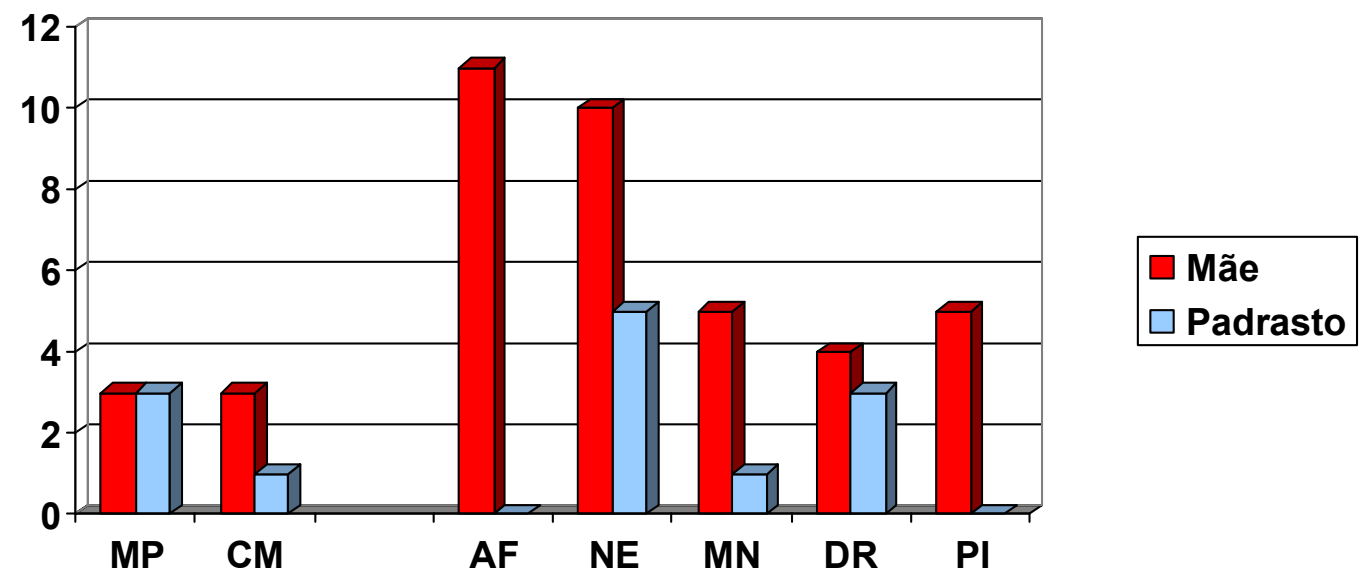

Figura 42. Práticas parentais da mãe e do padrasto.

A partir da Figura 42 é possível verificar também que o padrasto não fazia PI (punição inconsistente), diferentemente da mãe $(P I=5)$ e fazia pouca $M N$ (monitoria negativa), ou seja, era consistente em suas atitudes e não "pegava no pé” do adolescente. A disciplina relaxada não apresenta uma diferença relevante entre ambos os cuidadores. O padrasto não utilizava abuso físico.

Com estes resultados, que indicam o estilo parental de risco é possível compreender os dados obtidos na avaliação de habilidades interpessoais, que são indicativos claros da falta de repertório social, que neste caso pode ter como um dos fatores a falta de modelos adequados. De um total de 100 pontos possível no escore total do Inventário de Habilidades Sociais (IHS), o cliente atingiu apenas 10 pontos 
percentuais, ou seja, possui apenas dez por cento das habilidades necessárias para relacionar-se.

Após quatro meses de psicoterapia foi realizada uma nova aplicação do instrumento, que mostrou um aumento modesto de cinco pontos no escore total. Pequena alteração, justificável pela pouca ênfase do processo especificamente nas habilidades sociais. Este adolescente não participou de grupo de treinamento em habilidades sociais no programa da instituição, pois quando esta atividade foi implementada ele já havia sido desinternado.

$\mathrm{Na}$ experiência com adolescentes infratores de alto-risco no programa da Dra. Paula Gomide a sucessão destas reações parecia iniciar com a revelação ou confisssão, seguida da autocrítica verbalizada e então a reparação, quando possível.

$\mathrm{Na}$ prática da psicoterapia com adolescentes infratores de alto-risco foi possível observar o efeito imediato das práticas educativas positivas, principalmente da monitoria positiva, sobre os comportamentos do adolescente. Quando, por exemplo, o psicoterapeuta descrevia claramente regras e limites e agia coerentemente com o que dizia, era possível perceber menos incursões anti-sociais durante as sessões, ao passo que também ficava evidente a relação de confiança que o adolescente passava a manter com o psicoterapeuta.

\section{ANÁLISE DAS SESSÕES DE S11}

\section{Análise dos comportamentos do cliente S11}

Os comportamentos do cliente foram divididos em duas categorias para fins de análise dos dados. A categoria de comportamentos indesejáveis é composta por: hostilidade, mentira e externalização de culpa pelos atos aos outros. A categoria de comportamentos desejáveis compreende a auto-revelação, expressões de arrependimento e expressão de sentimentos positivos. 
Na Figura 43 é possível verificar que ao longo de vinte e oito sessões de psicoterapia diminuem os comportamentos indesejáveis e aumentam os comportamentos desejáveis, indicando uma modificação de comportamento satisfatória de acordo com os objetivos psicoterápicos.

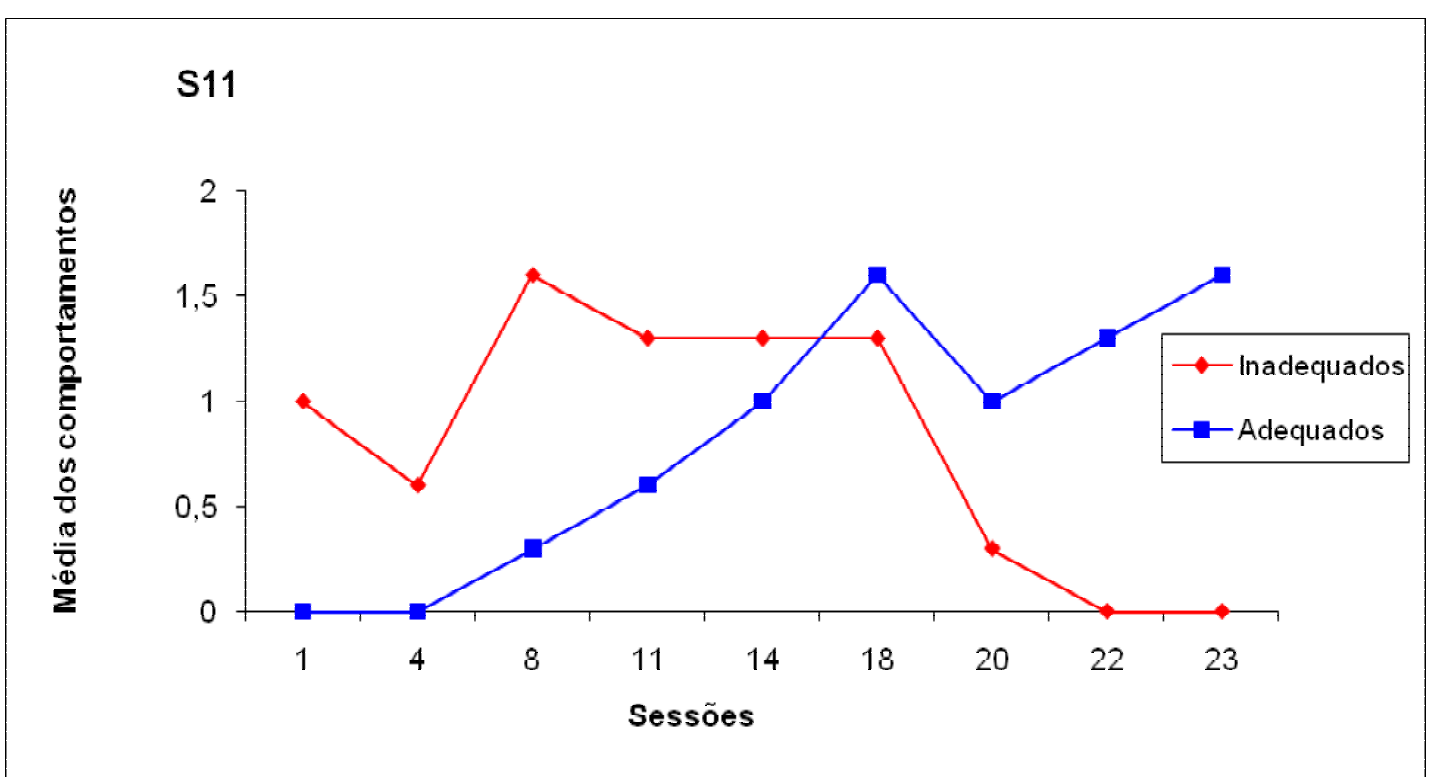

Figura 43. Médias dos comportamento indesejáveis e dos comportamentos desejáveis do cliente S11.

Em termos de análise individual dos comportamentos indesejados, a hostilidade apresentou maior ocorrência no decorrer das sessões, recebendo pontuação máxima em sete ocasiões. A mentira e a atribuição de culpa aparecem igualmente em quatro sessões cada uma. Testes não-paramétricos não apontam correlação significativa entre os comportamentos inadequados. A Figura 44 ilustra a ocorrência dos comportamentos indesejados por sessão, de forma que o valor 2 indica a ocorrência e o valor 0 indica a não ocorrência.

Quanto aos comportamentos desejáveis foram encontradas correlações significativas de ocorrência entre auto-revelação e expressão de sentimentos positivos (.926), e expressões de arrependimento e expressões de sentimento positivo (.780). A ocorrência dos comportamentos desejáveis ao longo das sessões de psicoterapia pode ser observada na Figura 45. 


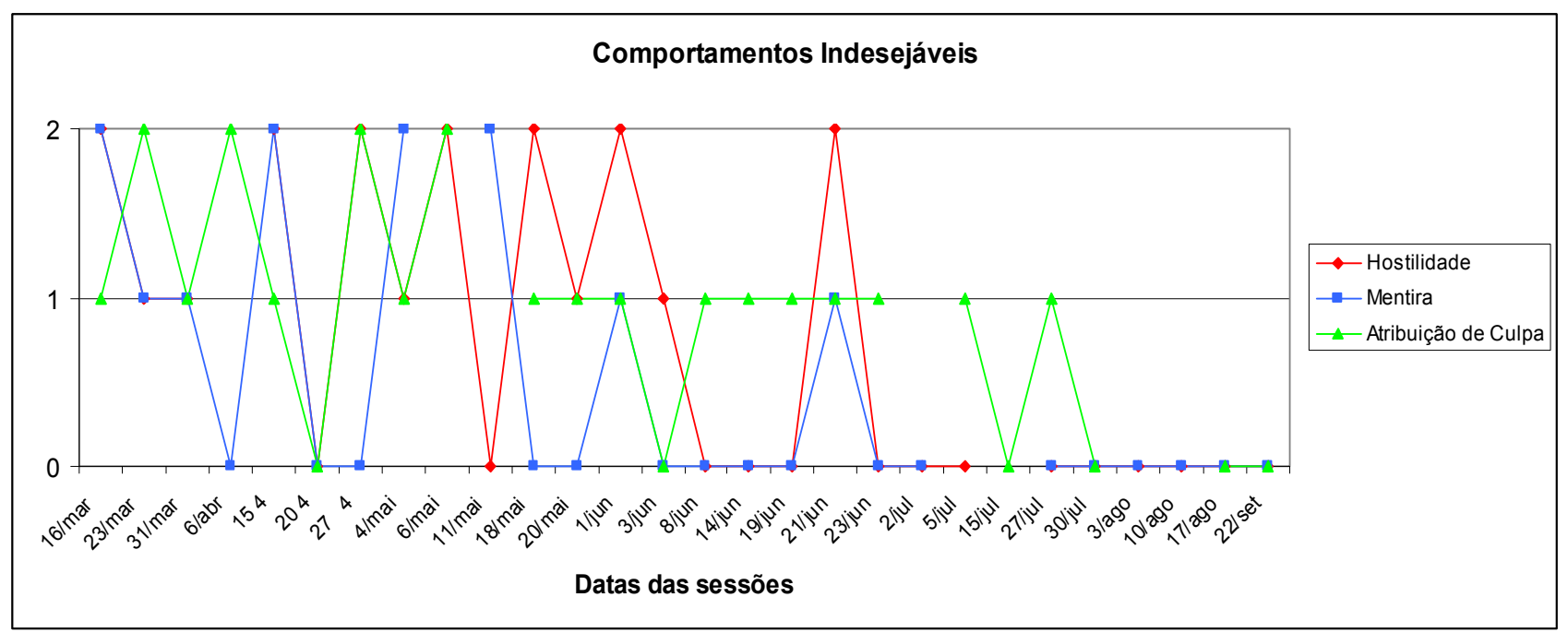

Figura 44. Comportamentos indesejáveis do cliente ao longo das sessões.

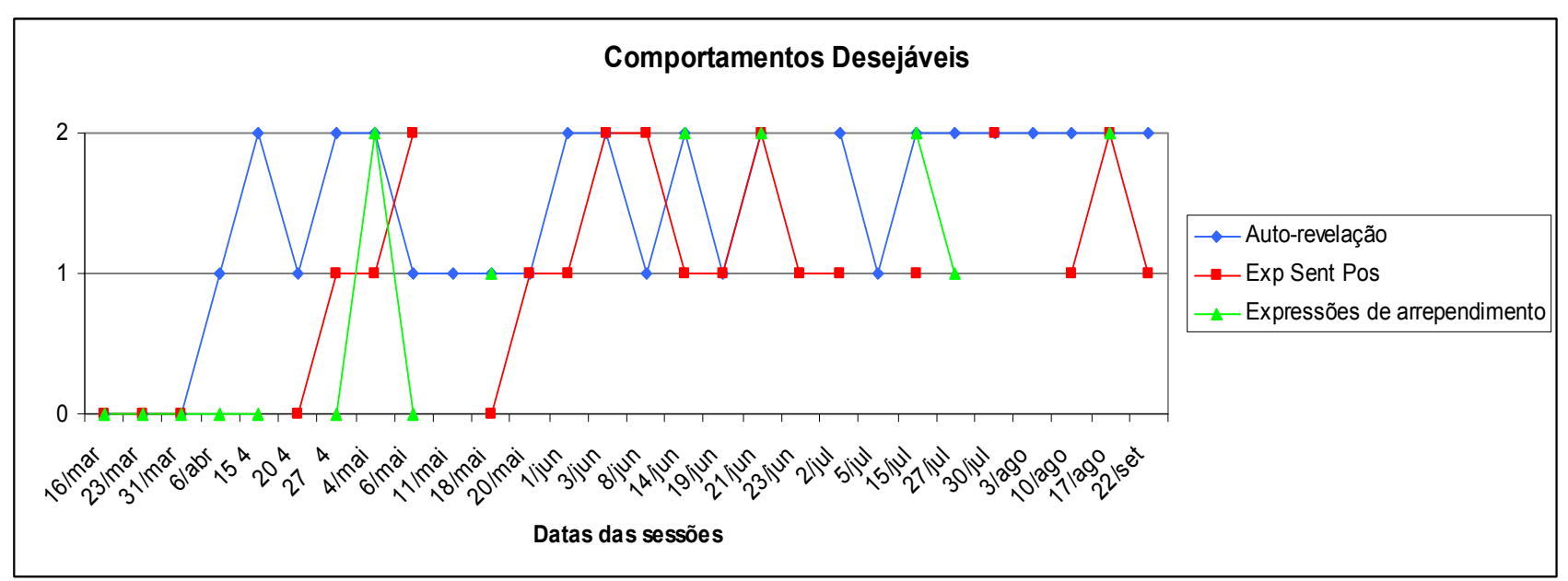

Figura 45. Comportamentos desejáveis do cliente ao longo das sessões.

\section{Análise dos comportamentos do terapeuta no Caso S11}

Os comportamentos do terapeuta foram analisados a partir do registro de onze sessões de psicoterapia. O comportamento com maior freqüência de ocorrência foi o de solicitar relatos $(32,8 \%)$, seguido por solicitar reflexão $(13,3 \%)$, interpretação $(11,9 \%)$ e fornecer informação $(11,6 \%)$. Os de ocorrência mais baixa foram: fazer recomendações $(2,9 \%)$, aprovação $(2 \%)$ e reprovação $(2,1 \%)$. A Figura 46 mostra a porcentagem (do total de todos comportamentos nas 11 sessões) de ocorrência de cada comportamento do terapeuta. 


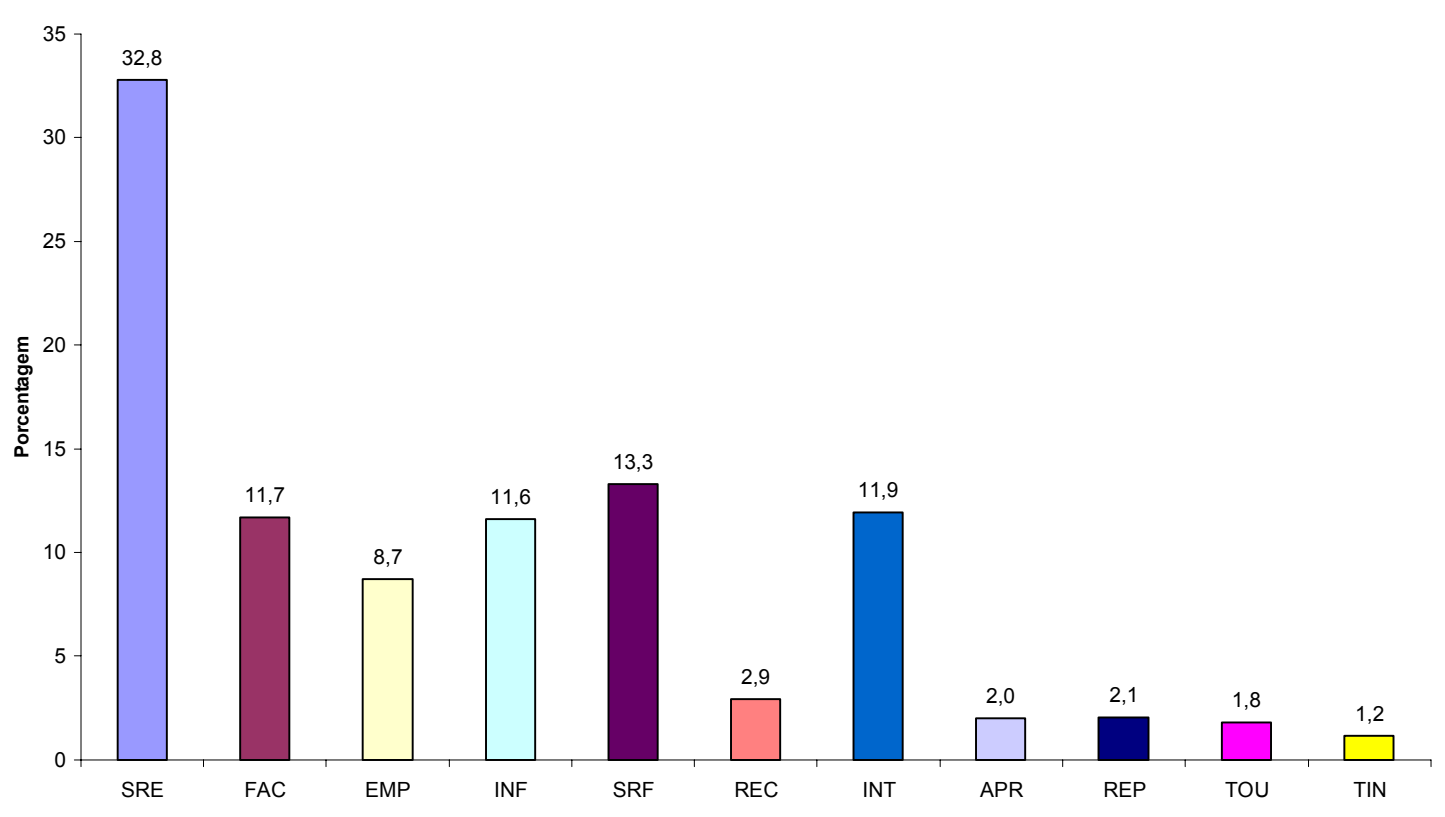

Figura 46. Porcentagem por categoria de comportamento do terapeuta.

Um dos fatores que poderia explicar a alta ocorrência da solicitação de relatos era o baixo repertório social do adolescente que não se comunicava espontaneamente e quando falava usava poucas palavras. Outra característica marcante é o número mais elevado de solicitação de reflexão sobre o número de recomendações, que poderiam vir em forma de orientações. Na psicoterapia com infratores deve-se levar em conta o caráter marcadamente opositor do comportamento, sendo então mais plausível o uso da solicitação de reflexões que levem a uma mudança de comportamento, ao invés de orientações diretas para a modificação.

Devido ao baixo repertório de comportamentos desejáveis ou pró-sociais dos infratores o psicoterapeuta acaba por fornecer muitas informações na tentativa de ampliar o repertório comportamental. Da mesma forma, quando o psicoterapeuta procede às interpretações, estabelecendo relações entre contingências, ele "ensina" ao cliente possíveis relações entre comportamentos. Este procedimento é bastante utilizado quando o profissional mostra quais conseqüências dos comportamentos indesejáveis. 
Dados relativos à categoria Empatia, Aprovação e Reprovação devem ser melhor estudados, pois a ocorrência, principalmente dos dois últimos é baixa, e não parece refletir o que de fato ocorre no processo psicoterápico.

\section{Comportamentos do cliente S11 X Comportamentos do Terapeuta}

Foi utilizado o teste estatístico não-paramétrico de correlação de Spearman a fim de se conhecer possíveis relações entre os comportamentos do terapeuta e do cliente.

O comportamento do terapeuta de solicitar relato correlaciona-se negativamente com o comportamento de auto-revelação do cliente (-.751). Este dado reflete fielmente o que acontece no contexto terapêutico, ou seja, não é o comportamento de perguntar que leva o cliente a falar dele mesmo. A auto-revelação apresentou correlações negativas também com os seguintes comportamentos do terapeuta: empatia (-.785), fornecer informação (-.777), interpretação (-.642) e aprovação (-.714), significando que quanto menos intervenções destes tipos, mais ocorrem auto-revelações.

A mentira correlacionou-se positivamente com os seguintes comportamentos do terapeuta: facilitação (.857), solicitar reflexão (.777), recomendação (.882), interpretação (.707) e aprovação (.687). Neste caso algumas hipóteses são possíveis. A relação entre mentira e solicitar reflexão poderia se dar quando o adolescente mentia, e ao invés de acusá-lo, o psicoterapeuta sugeria um exercício de reflexão que levasse o cliente a perceber o próprio comportamento. Da mesma forma, as recomendações e interpretações poderiam ocorrer em função do comportamento de mentir do cliente, fazendo então com que ocorrência destes comportamentos se desse proporcionalmente. O comportamento de aprovação pode estar relacionado ao de 
mentir, mais especificamente, ao falar da mentira cometida. Caso houvesse reprovação o comportamento de contar as mentiras que dizia para os outros poderia cessar, interrompendo o fluxo de aceitação do terapeuta e consequentemente prejudicando o vínculo entre eles. A mesma coisa pode ser dita sobre a facilitação.

Outra correlação que pode ser discutida é a que ocorre entre os comportamentos de atribuir culpa aos outros e fornecer informações. É possível que frente ao comportamento do terapeuta de explicar um fato, por exemplo, pela via prósocial, que o cliente justifique sua discordância ou atitudes contrárias ao esperado, atribuindo responsabilidades aos outros, eximindo-se da responsabilidade pelo próprio comportamento. E ainda, quando o cliente apresentava o comportamento de culpar os outros pelos próprios atos, pode ser que o terapeuta fornecesse informações a fim de confrontar o cliente, uma prática comum na psicoterapia com infratores.

Em termos das práticas educativas que o psicoterapeuta utiliza é importante levantar a hipótese de que quando reprova o comportamento do clienteinfrator, o efeito sobre o comportamento deste difere do que poderia ser para um cliente como os que vão aos consultórios e clínicas-escola. O efeito da reprovação, somada à informação e interpretação, parecem componentes da monitoria positiva, com a qual o infrator não está acostumado, mas que rapidamente aprende a respeitar, pois através desta prática os limites são colocados de forma que o jovem sente-se valorizado.

Também através da reprovação, quando esta estabelece limites, fornece novos repertórios e mostra os sentimentos genuínos do psicoterapeuta, percebe-se outra prática educativa em questão, o comportamento moral. Essencial para formal de vínculo com o adolescente infrator, a sinceridade, seja ela através de uma reprovação, estabelecimento de limites e até um elogio verdadeiro, é importante fator moral que deve ser ensinado no processo terapêutico. 


\section{Resultados dos Indicadores Gerais de Modificação de Padrão Anti-social}

Esta seção visa sistematizar os dados referentes a todos os adolescentes através do que se pode chamar de indicadores de modificação de comportamento antisocial. Estes indicadores referem-se a comportamentos complexos que promovem a manutenção de um repertório não-infrator.

Tabela 17. Indicadores de modificação do comportamento infrator.

\begin{tabular}{|c|c|c|c|c|c|c|c|c|}
\hline & 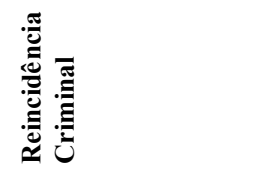 & 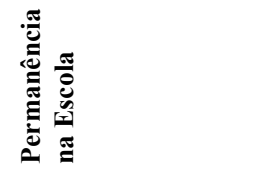 & 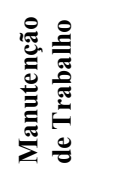 & 总 & 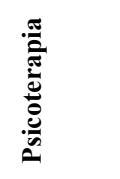 & 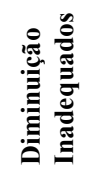 & 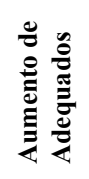 & 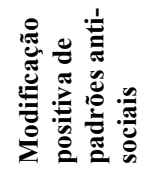 \\
\hline S1 & Parcial & Sim & Parcial & Parcial & Sim & Sim & Sim & Sim \\
\hline S2 & Sim & Parcial & Parcial & Parcial & Não & Não & Não & Não \\
\hline S3 & Sem Informação & Sem Informação & Parcial & Sim & Não & Sim & Sim & Sim \\
\hline S4 & Não & Sim & Parcial & Sim & Sim & Sim & Sim & Sim \\
\hline S5 & Sim & Não & Não & Não & Não & Sim & Sim & Não \\
\hline S6 & Não & Não & Parcial & Parcial & Não & Sim & Sim & Sim \\
\hline S7 & Parcial & Parcial & Não & Não & Parcial & Sim & Sim & Parcial \\
\hline S8 & Sem Informação & Sim & Sim & Parcial & Não & Não & Não & Não \\
\hline S9 & Não & Não & Parcial & Sim & Sim & Sim & Sim & Sim \\
\hline S10 & Não & Sim & Sim & Sim & Sim & Sim & Sim & Sim \\
\hline S11 & Não & Parcial & Sim & Sim & Sim & Sim & Sim & Sim \\
\hline
\end{tabular}

A Tabela 17 apresenta informações quanto a alguns critérios que foram citados nos objetivos desta pesquisa. Quanto à reincidência criminal, quando se classifica o item como parcial significa que foi cometida infração, porém não se atentou contra vida ou integridade física de outrem. Portanto quando se indica que o participante 1 reincidiu parcialmente quer dizer que a infração cometida é de baixa gravidade se comparada às cometidas antes do processo psicoterápico. O S7 fugiu em atividade externa e subsistiu traficando drogas até ser reaprendido, por isso considera-se infração 
parcial, pois é de menor gravidade do que as que ele cometia antes do processo psicoterápico. O adolescente S2 reincidiu cometendo crime da mesma gravidade, mesmo após o processo psicoterápico e o S5 cometeu crime de menor gravidade, porém por ser maior de idade foi condenado a cumprir pena no regime penitenciário.

No item Permanência na Escola, a classificação parcial indica que o indivíduo continuou estudando por um período de tempo e interrompeu (S11), ou para os encarcerados (S2, S7), parcial significa estar estudando na prisão.

Quanto à manutenção de trabalho observa-se que para os adolescentes S5 e S7 há indicação "NÃO", significando que nenhum deles obteve emprego fixo e nestes casos especificamente, ambos reincidiram criminalmente. Porém, o jovem S2, que também reincidiu, obteve classificação "PARCIAL" porque no breve período de tempo em que ficou em liberdade ele participou de um programa governamental de primeiro emprego para adolescentes e manteve-o por dois meses. Os demais jovens, que neste item receberam avaliação "PARCIAL" encontram-se em liberdade e não possuem emprego formal, mas fazem "bicos" ou trabalham no mercado informal, sem registro em carteira de trabalho.

Observa-se que relativo ao auto-sustento, este não pode ocorrer em decorrência de atividades ilícitas. Quando este item é classificado como "PARCIAL" diferentes situações podem ser encontradas. S1, S6 e S8 dependem em parte da renda financeira familiar, moram com familiares, ou seja, ainda não subsistem sem ajuda de terceiros. S2 obteve esta avaliação porque enquanto esteve em liberdade subsistiu parcialmente de seu trabalho, pois mais tarde soube-se que ele estava traficando pequenas quantias de droga enquanto trabalhava no mercado formal. S5 e S7 não alcançaram auto-sustento pois não tiveram nenhum tipo de atividade remunerada nãoilícita e ambos encontram-se encarcerados. 
Cinco adolescentes permaneceram em terapia após o desinternamento: S1, S4, S9, S10 e S11. Atualmente ${ }^{19} \mathrm{~S} 1, \mathrm{~S} 4$ e S10 moram em outros municípios e mantém contato telefônico esporádico com a terapeuta. S9 perdeu contato, mas sabe-se dele através de contatos telefônicos com a mãe. S11 residiu por mais de um ano fora do estado e encontra-se em terapia. O adolescente S7 é um exemplo de forte vínculo terapêutico desenvolvido, pois mesmo foragido solicitava atendimentos à terapeuta e já comunicou a um educador que vai procurar a terapeuta quando for desinternado, pois “sei que ela é firmeza e posso contar com ela pra ter uma vida melhor lá fora e ajudar minhas irmãs"(SIC). S5 fugiu e teve sua terapia interrompida pois fugiu, reincidiu e está preso novamente. S8 teve sua psicoterapia interrompida ainda durante o internamento. S3 e S6 se mudaram de cidade em decorrência do próprio desinternamento e não mantiveram contato com a terapeuta. S2 continuou a psicoterapia quando foi desinternado, mas mudou-se de cidade e interrompeu o processo. Quando foi internado novamente solicitou psicoterapia mas não houve tempo para retomar seu atendimento, pois ocorreu a saída da terapeuta da unidade.

As colunas "Diminuição de Inadequados" e "Aumento de Adequados" da Tabela 17 apenas resumem os dados dos gráficos apresentados em cada caso desta discussão.

A última coluna "Modificação Positiva do Padrão de Comportamento Anti-social" busca identificar a combinação dos fatores que poderia ser considerada o sucesso de uma intervenção junto a população infratora. Sendo assim, pode-se verificar que dos 11 casos atendidos, sete tiveram modificação positiva do padrão de comportamento anti-social e um (S7) teve modificação parcial, pois apesar de reincidir e estar preso, acredita-se que ainda dará continuidade ao processo terapêutico.

\footnotetext{
${ }^{19}$ Dados obtidos na ocasião de conclusão do trabalho escrito, em junho de 2008.
} 
Com os dados levantados recentemente pela pesquisadora (junho de 2008) tem-se que:

S1

Está em liberdade novamente, tem um filho, mora na casa da namorada, que é de classe média baixa, e trabalha com o pai dela, o avô de seu filho.

S2

Preso, diagnosticado como psicopata. Será posto em liberdade em até dezoito meses.

S3

Em liberdade, trabalha informalmente.

S4

Em liberdade, trabalha informalmente, mora e cuida dos avós.

S5

Meses depois de sua fuga, soube-se que por ser maior de idade estava preso na delegacia de furtos.

S6

Em liberdade, estava morando com a mãe alcoolista. Voltou a usar drogas e foi espancado pela polícia durante uma blitz. Ficou em coma por quase um mês e agora, segundo uma tia, ficou "abobado", não reconhece as pessoas e somente dá risadas. 
S7

Está preso e relata que voltará para terapia para ter uma vida melhor e ajudar as irmãs.

\section{S8}

Está em liberdade. Diagnosticado psicopata.

S9

Está em liberdade. Casado, pai de uma criança, cuida da irmã e mãe doentes.

S10

Está em liberdade, mora com os pais e ajuda-os financeiramente. Liga pelo menos uma vez por mês para a terapeuta.

\section{S11}

Está em liberdade, trabalha em um grande clube de futebol na área de manutenção e serviços gerais, está procurando um quarto para alugar e temporariamente mora com o irmão, ajudando nas despesas da casa. Acorda diariamente às cinco da manhã e trabalha de segunda a sábado. Vai quinzenalmente para a terapia e no dia 24 de junho de 2008 enviou a seguinte mensagem para a terapeuta: "Muito obrigada por você ter entrado na minha vida. Você é a única pessoa que eu sei que gosta de mim de verdade. Obrigada minha terapeuta!" 


\section{CONSIDERAÇÕES FINAIS}

"We could solve many of the problems of delinquency and crime if we could change the early environment of offenders.” (Skinner, 1948, p.11)

É maravilhoso e assustador que Skinner, na década de quarenta do século passado, já tivesse descrito as possibilidades que a análise do comportamento oferecia para que trabalhássemos com transgressores. Maravilhoso porque há mais de cinqüenta anos a análise do comportamento vem oferecendo instrumentos para lidarmos com os mais variados tipos de mazelas humanas. Assustador porque ainda hoje muitas pessoas desconhecem, ignoram ou rejeitam os conhecimentos acumulados por cientistas do comportamento nas mais variadas áreas onde se requer solução de problemas sociais, de saúde, família, escola, dentre quaisquer outros.

Ao longo dos meses nos quais realizei este trabalho estive trabalhando com técnicos concursados do estado, psicólogos, pedagogos e assistentes sociais, alguns com muitos anos de experiência com infratores e outros recém-contratados, na maioria jovens recém-saídos das universidades. Pouquíssimas destas pessoas, na verdade não conseguiria me recordar de uma exceção, possuíam formação específica para trabalhar com infratores tampouco possuíam uma sólida base teórica, qualquer que fosse ela, que subsidiasse o trabalho realizado. Dada a complexidade do trabalho aqui apresentado, é possível imaginar que o despreparo de grande parte dos profissionais que trabalham com estes adolescentes tenha consequências desastrosas para toda a sociedade.

Uma das lições desta experiência é que os analistas do comportamento que trabalham nesta área da psicologia forense no Brasil precisam sistematizar e divulgar seus trabalhos, mostrando as enormes possibilidades que advém dos princípios behavioristas. Tive apenas dois anos para desenvolver este trabalho e imagino o quanto 
os técnicos que permanecem por quinze, vinte ou trinta anos poderiam fazer. O que conduz à uma das limitações da presente pesquisa, o acompanhamento dos adolescentes após o desinternamento.

Apesar de conhecer a importância da continuidade do trabalho e acompanhamento dos casos para verificar a generalização da aprendizagem de comportamentos pró-sociais e a não-reincidência criminal, em vários casos tive dificuldade de fazê-lo. Alguns dos motivos que tornaram esta tarefa árdua foram a falta de acesso a dados que somente funcionários do estado poderiam ter para localizar os adolescentes, bem como os elevados custos de realizar esta localização e contato em outras cidades e estados sem apoio financeiro do estado. É sabida a necessidade de obter dados com freqüência determinada e a longo prazo para que a intervenção possa ser considerada bem-sucedida, e sugere-se que estudos futuros possam dar conta deste procedimento.

Além disso tive oportunidade de conhecer o sistema socioeducativo e penitenciário de alguns estados e percebi que o psicólogo na maioria das vezes tem nele função de proceder à avaliações e confeccionar relatórios e pareceres. Muitas vezes não possui instrumentos formais ou formação teórica para tal, e sendo assim acaba por exercer a função de um burocrata que repete procedimentos-padrão que pouco, ou nada, contribuem para a modificação dos padrões de comportamento anti-social com os quais lida. Desconheço a existência no país de um programa como aquele do qual fiz parte realizando a psicoterapia dos infratores e quando questionava meus colegas psicólogos sobre a possibilidade de realizar terapia com os internos obtive respostas fundamentadas na falta de tempo para realizá-la ou na perda de tempo que seria realizá-la. Infelizmente muitos profissionais do estado não acreditam que haja possibilidade de mudança para estes jovens e adultos presos. 
Espero que este trabalho, apesar de não ter obtido sucesso absoluto com todos os clientes e de não ter as condições ideais de acompanhamento para afirmação da generalização dos resultados a outros ambientes e ao longo do tempo, possa servir como disparador sobre a "utilidade" da psicoterapia dos transgressores, obviamente realizada por profissionais especificamente habilitados para tanto.

Considero de fato que apenas dois dos casos não tenham se beneficiado da psicoterapia, o caso S5 e o S8. Não foi ofertado o devido tratamento ao comportamento de uso e abuso de substâncias psicoativas para o adolescente 5. As unidades de internamento conhecem a necessidade de se ter estratégias eficazes para o tratamento da dependência química, mas parece não haver consenso sobre o assunto, tendo em vista que programas sabidamente eficazes (Alcoólicos Anônimos, Narcóticos Anônimos) não faziam parte das atividades das unidades de internamento de adolescentes no Paraná enquanto realizei este trabalho.

Já com o adolescente 8 considero que somente possuía o conhecimento das variáveis presentes no caso quando já não havia tempo de dar continuidade aos atendimentos devido à minha saída da unidade. A lição aprendida daqui: sim, psicopatas existem, estão entre nós e precisamos aprender a tratá-los ao invés de dizer que é impossível tratá-los. A literatura internacional mostra alguns tímidos, porém animadores avanços nesse sentido. Apenas é preciso que alguém queira experimentar, ou seja, que se disponha a tentar.

Para trabalhar com adolescentes infratores, transgressores graves, é preciso que se tenha disponibilidade. É uma tarefa capaz de consumir longas horas de nossas mais profundas reflexões, provoca reações e emoções ora desagradáveis, ora incomensuráveis, faz-nos questionar valores humanos e o que é importante de fato em nossas vidas. Após oito anos de formatura, quando iniciei a terapia do "meu" primeiro 
menino infrator, não imaginava o quanto aprenderia aplicando os princípios da análise do comportamento no manejo com o infrator grave.

Como os onze adolescentes atendidos por mim, e que passaram pelo Programa para Adolescentes Infratores de Alto-risco, não sou a mesma. E mais do que nunca entendo a seguinte passagem de Skinner (1989) com a qual encerro este texto, pois resume o que é preciso fazer.

"Quando se perguntou a Gandhi: "O que devemos fazer?",conta-se que ele replicou: "Pense no homem mais pobre que você jamais encontrou e pergunte se o que você está fazendo o beneficia de alguma forma". O sentido de "o beneficia" deve porém ter sido o de que "muita gente possa assemelhar-se a você, sem a sua ajuda". Alimentar os famintos e vestir os nus são atos curativos. Podemos perceber facilmente o que está errado e o que necessita ser feito. É muito mais difícil ver e fazer algo diante do fato que a agricultura mundial deve alimentar e vestir bilhões de pessoas, a maioria ainda nem nascidas. Não é suficiente aconselhar as pessoas sobre como comportar-se de modo que tornem possível o futuro da espécie; devem ser-lhes dadas razões efetivas para comportar-se, e isso significa contingências efetivas de reforçamento." (p.98) 


\section{Referências Bibliográficas}

American Psychiatric Association.(2002) Diagnóstico e Estatístico de Transtornos mentais - texto revisado. Porto Alegre: ArteMed

Albeniz, A.P. \& Paul, J. (2003) Dispositional empathy in high- and low-risk parents for child physical abuse. Child Abuse \& Neglect, 27, 769-780.

Allen, L. C., MacKenzie, D. L., \& Hickman, L. J. (2001). The effectiveness of cognitive behavioral treatment for adult offenders: A methodological, quality-based review. International Journal of Offender Therapy and Comparative Criminology, 45, 498-514.

Adams, R. e Vetter, H.J. (1981) Social structure and psychodrama outcome: A ten-year followup. Journal of Offender Counseling Services \& Rehabilitation, 6, 111-119.

Andrews, D. A., Zinger, I., Hoge, R. D., Bonta, J., Gendrau, P., \& Cullen, F. T. (1990). Does correctional treatment work? A clinically relevant and psychologically informed meta-analysis. Criminology, 28, 369-403.

Araújo, U. F. (1999) A vergonha como um regulador moral. Campinas: Editora da Unicamp.

Assis, S.G. (1999) Traçando caminhos em uma sociedade violenta. Rio de Janeiro: Editora Fiocruz.

Ballone, G. J. (2006). Sobre a Mentira. PsiqWeb [On-line]. Disponível: http://virtualpsy.locaweb.com.br/index.php?art=395\&sec=35. Recuperado em 20/08/2006.

Banaco, R. (1993) O impacto do atendimento sobre a pessoa do terapeuta. Temas em psicologia, v. 2, p. 71-79.

Barber, B.K. (1996) Parental Psychological Control: Revisiting a Neglected Construct.

Child Development, Vol. 67, No. 6, pp. 3296-3319

Barnow, S., Lucht, M. \& Freyberger, H.J. (2001) Influence of punisment, emotional rejection, child abuse, and broken home on aggression in adolescence: an examination of aggressive adolescents in Germany. Psychopathology, 34, 167-173.

Baum, W.M. (1999). Compreender o behaviorismo: ciência, comportamento e cultura. Porto Alegre, RS: editora - Artes Médicas Sul Ltda.

Beck, J. S. (2007) Terapia Cognitiva para desafios clínicos. Porto Alegre: Artmed.

Benda, B.B. e Whiteside, L. (1995). Religion and Delinquency: The Relationship after Considering Family and Peer Influences. Corwyn Journal for the Scientific Study of Religion, Vol. 36, No. 1, pp. 81-92.

Berri, G. (2004) Programa de Intervenção em Práticas Parentais para Mães de Adolescentes em Conflito com a Lei. Dissertação apresentada ao Programa de Pós-graduação em Psicologia da Infância e Adolescência. Curitiba: UFPR.

Bowlby, J. (1984). Apego e Perda. São Paulo: Martins Fontes. 
Bolsoni- Silva, A. T. \& Marturano, E.M. (2002). Práticas Educativas e Problemas de Comportamento: Uma Análise à Luz das Habilidades Sociais. Estudos de Psicologia, vol 07 (2), pp. 227-235.

Bolsoni- Silva, A.T. (2003) Habilidades Sociais Educativas, variáveis contextuais e problemas de comportamento: comparando pais e mães de pré-escolares. Tese de Doutorado.Universidade de São Paulo: Programa de Pós-graduação em Psicologia e Educação.

Brandão, M.Z.S. \& Rocha, M.M.; (2001). A importância do autoconhecimento dos pais na análise e modificação de suas interações com os filhos. In: M. Delitti (org). Sobre Comportamento e Cognição: A Prática da Análise do Comportamento e da Terapia CognitivoComportamental. Santo André: ESETec, vol 2, pp. 133- 141.

Brasil. (1989) Constituição da República Federativa do Brasil. Brasil. Brasília: Diário Oficial da União.

Brasil. (1990) Estatuto da Criança e do Adolescente: Lei Federal 8069, de 13 de Julho de 1990.

Brasil.(2006) Ministério da Justiça - Sistema nacional de Atendimento Socioeducativo - Sinase. Disponível em http://www.mj.gov.br/sedh/ct/spdca/sinase/sinase.pdf acesso em 15/06/2007

Brugman, D., Heymans, P.G., Boom, J., Podolskij, A.I., Karabanova, O. \& Idobaeva, O. (2003). Perception of moral atmosphere in school and norm transgressive behaviour in adolescents: an intervention study. International Journal of Behavioral Development, 27(4), 289-300.

Bzuneck, J.A. (1979) Julgamento moral de adolescentes delinquentes e não-delinquentes em relação com a ausência paterna. Tese de doutorado não-publicada, Curso de Pós-graduação em Psicologia Escolar, Universidade de São Paulo, São Paulo, SP.

Caballo, V.E. (1993) Manual de evaluación y entrenamiento de las habilidades sociales. Espanha: Siglo Veintiuno de España Editores.

Caballo, V. E. e Torrecillas, F. L. (2008) O transtorno da Personalidade anti-social. Em V.E. Caballo (Org.) Manual de Transtornos de Personalidade. São Paulo: Editora Santos.

Cahill, S.P., Carrigan, M.H., \& Evans, I.M. (1998). The future of the relationship between behavior theory and behavior therapy: Challenges and promises. In G. Eifert \& J. Plaud (Eds.), From behavior theory to behavior therapy. Boston: Allyn \& Bacon.

Cairns, R., Cadwallader, T., Estell, D. \& Neckerman, H. (1997) Groups of Gangs: developmental and criminological perspectives and relevance for prevention. In D. Stoff, J. Breiling \& J. Maser (Orgs.) Handbook of antisocial behavior. EUA: John Wiley \& Sons.

Caldwell, M. F., Mc Cormick, D.J., Umstead, D. e Van Rybroek, G.J. (2007) Evidence of Treatment Progress and Therapeutic Outcomes Among Adolescents With Psychopathic Features. Criminal Justice and Behavior 2007; 34; 573.

Capaldi, D., Chamberlain, P. \& Patterson, G. (1997) Innefective Discipline Conduct Problems in Males: association, late adolescents outcomes and prevention. Aggressive and violent behavior, 2, 343-353.

Capaldi, D., Chamberlain, P. \& Patterson, G. (1997) Innefective Discipline Conduct Problems in Males: association, late adolescents outcomes and prevention. Aggressive and violent behavior, 2, 343-353. 
Castonguay, L. G. \& Beutler, L. E. (2006). Principles of therapeutic change: What do we know and what do we need to know? Em L. E. Beutler \& L. G. Castonguay (Eds.), Principles of effective therapeutic change that work. New York: Oxford University Press.

Cavell, T. (2000). Working with Parents of Agressive Children: a practitioner's guide. Washington: American Psychological Association.

Cavell, T. (2001). Updating Our Approach to Parent Training I: The Case Against Targeting Noncompliance. Journal of Clinical Psychology, vol 8 (3), pp. 299-318.

Cavell, T.A., (2006). The anger-aggression relation. In T. A. Cavell \& K. Malcolm (Eds.), Anger, Aggression, and Interventions for Interpersonal Violence. Mahwah, NJ: Lawrence Erlbaum Associates, Inc.

Cernkovich, S.A. e Giordano, P.C. (1987) Family relationships and delinquency. Criminology, $\underline{25,}, 401-427$.

Chamberlain, P., Fisher, P. \& Moore, K. (2002) Multidimensional treatment foster care: applications of the OSLC Intervention Model to Highrisk youth and their families. In J.Reid, G. Patterson \& J. Snyder. Antisocial behavior in children and adolescents: a developmental and model for intervention. APA: Washington, D. C.

Chequer. M.A.A. \& Martinelli, J.C.M. (2004a) Análise do comportamento responsabilidade social e formação profissional na Univalle. Em A.C.Cruvinel et al.(Orgs) Ciência do Comportamento: conhecer e avançar. Santo André: ESETec

Chequer. M.A.A. \& Martinelli, J.C.M. (2004b) O contexto de prestar serviços na clínica comportamental e responsabilidade social. Em A.C.Cruvinel et al.(Orgs) Ciência do Comportamento: conhecer e avançar. Santo André: ESETec

Chies, L. A. B. (2004) Resenha: As prisões em São Paulo. Sociologias, 11, 328-342.

Christle, C.A., Nelson, C.M. \& Jolivette, K. (2002) Prevention of Antisocial and Violent Behavior in Youth: a review of the literature. Universitu of Kentucky.

Obtido em 16 de maio de 2007: http://www.edjj.org/focus/prevention/plr.pdf

Cirino, S.D. (2005) Educação, ensino e formação de propfessores: contribuições da análise do comportameto. In: H. Guilhardi \& N.C. Aguirre (org). Sobre Comportamento e Cognição: expondo a variabilidade. Santo André: ESETec, vol. 16, pp. 279- 286.

Conte, F.C.S. (1996) Pesquisa e Intervenção Clínica em Comportamento Delinqüente numa Comunidade Pobre. Tese de Doutorado, Universidade de São Paulo.

Conte, F.C.S. (2001) Promovendo a relação entre pais e filhos. In: M. Delitti (org). Sobre Comportamento e Cognição: A Prática da Análise do Comportamento e da Terapia CognitivoComportamental. Santo André: ESETec, vol. 2, pp. 161- 168.

Coohey, C. (2003) Making judgments about risk in substantiated cases of supervisory neglect. Child Abuse \& Neglect, 27, 821-840.

Cordova. J.V. e Kohlenberg, R.J. (1994) Acceptance and the therapeutic relationships. Em S.C. Hayes, N.S. Jacobson, V.M. Follette e M.J. Dougher (Eds.) Acceptance and change: content and context in psychotherapy. Reno, USA: Context Press. 
Costa, F.T.; Teixeira, M.A .;Gomes, W.B. (2000). Responsividade e Exigência: Duas Escalas para Avaliar Estilos Parentais. Psicologia, Reflexão e Crítica, vol 13 (3), pp. 465 - 473.

Cowles, C.A. \& Washburn, J.J. (2005) Psychological Consultation on Program Design of Intensive Management Units in Juvenile Correctional Facilities. Professional Psychology: Research and Practice. Volume 36(1).pp.44-50.

Crittenden, P.M. (1985). Maltreated infants: vulnerability and resilience. Journal of Child Psychology and Psichiatry and Allied Disciplines, vol 26, pp. 85-96.

DeFraine, C. A. S. (1997). Motivation And Belief In Personal Lying. Dissertação de Doutorado. Faculty of the Graduate School of Valderbilt University. Nashville, Tennessee.

DePaulo, B. M. \& Kashy, D. A. (1998). Everyday lies in close and casual relationships. Journal of Personality and Social Psychology. 74, 63-79.

De La Taille, Y.(1997) Para um estudo psicológico da honra. Em L. Banks-Leite (Org.). Percursos Piegetianos. São Paulo: Editora Cortez.

Del Prette \& Del Prette (2000) Inventários de Habilidades Sociais: manual e aplicação. São Paulo: Casa do Psicólogo.

Del Prette, A. \& Del Prette, Z.A P. (1999) Psicologia das Habilidades Sociais: terapia e educação. Petrópolis: Vozes.

Del Prette, A. \& Del Prette, Z. (2001) Psicologia das relações interpessoais: vivência para o trabalho de grupo. Petrópolis: Vozes

Dishion, T. \& Andrews, D.W. (1995). Preventing Escalation in Problem Behaviors with HighRisk Young Adolescents: Immediate and 1 Year Outcomes. Journal of Consulting and Clinical Psychology, vol 63 (4), pp.538-548.

Dishion, T. \& Kavanagh, K. (2002) The adolescent transitions program: a family-centered prevention strategy for schools. In J.Reid, G. Patterson \& J. Snyder. Antisocial behavior in children and adolescents: a developmental and model for intervention. APA: Washington, D. C.

Dodge, K.A., Pettit, G.S. \& Battes, J.E. (1994). Socializations mediators of the relation between socioeconomic status and child conduct problems. Journal of Child Development, vol 65, pp. 649-665.

Ducharme, J.M., Atkinson, L. \& Poulton, L. (2001) Errorless compliance training with physically abusive mothers: a single-case approach. Child Abuse \& Neglect, 6, 855-868.

Falcone, E. (1998) Programa de treinamento da habilidade empática. Tese de doutoramento. São Paulo: USP.

Feldman, M. P. (1979) Comportamento Criminoso: uma análise psicológica. Rio de Janeiro: Zahar Editores.

Feldman, M. P. (1993) The Psychology of Crime. New York, USA: Cambridge University Press. 
Fergusson, D.M., Horwood, L.J. e Lynskey, M.T. (1994) The childhoods of multiple problems adolescents: a 15 year longitudinal study. Journal of Child Psychology and Psychiatry, 35, 1123-1140.

Flight, J.I. e Forth, A.E. (2007) Instrumentally Violent Youths: The Roles of Psychopathic Traits, Empathy, and Attachment. Criminal Justice and Behavior; 34; 739.

Florsheim, P., Shotorbani, S., Guest-Warnick, G., Barrat, T. \& Hwang, W, (2000) Role of the working alliance in the treatment of delinquent boys in community-based programs. Journal of clinical child psychology, Vol. 29, 1, 94-107.

Florsheim, P., Behling, S., South, M., Fowles, T.R. \& DeWitt, J.(2004) Does the Youth Corrections System Work?: Tracking the Effectiveness of Intervention Efforts With Delinquent Boys in State Custody. Educational Publishing Foundation. Volume 1(2). pp. 126-139.

Follette, W.C., Naugle, A.E. e Callaghan, G.M. (1996) Useful constructions of the clienttherapist relationship. Psychotherapy, 33, 3, 381-390.

Forgatch, M. \& DeGarmo, D. (2002) Extending and testing the social interaction learning model with divorce samples. In J.Reid, G. Patterson \& J. Snyder. Antisocial behavior in children and adolescents: a developmental and model for intervention. APA: Washington, D. C.

Fox, R. \& Brenner, V. (1999) An empirically derived classification of parenting practices. Journal of Genetic Psychology, 160, 343-...

França, F. (2004) Psicologia Jurídica e seu panorama no Brasil. Psicologia: Teoria e Prática, 6 (1): $73-80$

Freitag, B. (1984). Sociedade e consciência: Um estudo piagetiano na favela e na escola. São Paulo, Cortez.

Garfield, S.L. (1995) Psychotherapy: an ecletic-integrative approach. New York: John Wiley \& Sons.

Gershoff, E.T. (2002). Corporal Punishment by Parents and Associated child behaviors and experiences. Psychological Bulletin, 128, pp.539-579.

Gibbs, J.C. (1991). Toward an integration of Kohlberg's and Hoffman's theories of morality. Em W.M. Kurtines \& J.L. Gewirtz (Eds.). Handbook of moral behavior and development (Vol. 3).

Hillsdale, NJ, USA: Lawrence Erlbaum Associates Inc.

Gomide, P. I. C.; Carvalho, M. C. N.; Ingberman, Y. K. (2004) Comportamento Infrator: Locus de causalidade. In: Maria Zilah da Silva Brandão; Fátima Cristina de Souza Conte et. al. (Org.). Sobre o Comportamento e Cognição. Santo André: ESETec. (p. 38-47).

Gomide, P. I. C. ; Rocha, G.V.M. e Watanabe, A. (2005) Avaliação de desempenho escolar em adolescentes infratores de alto risco. Apresentação de Trabalho/Comunicação em Congresso.

Gomide, P.I.C. (1998) Menor infrator: a caminho de um Novo Tempo. Curitiba: Juruá Editora.

Gomide, P.I.C. (2001). Efeitos das práticas educativas no desenvolvimento de comportamento anti-social. In: M. L. Marinho \& V. E. Caballo (orgs). Psicologia Clínica e da Saúde. Londrina: UEL; Granada: APICSA. 
Gomide, P.I.C. (2003) Estilos parentais e comportamento anti-social. Em A. Del Prette \& Z.A.P. Del Prette (Orgs.) Habilidades Sociais, Desenvolvimento e Aprendizagem: questões conceituais, avaliação e intervenção. Campinas: Alínea Editora.

Gomide, P.I.C. (2004) Pais presentes, Pais Ausentes. Petrópolis: Vozes.

Gomide (2006).Inventário de Estilos Parentais. Petrópolis: Editora Vozes.

Goyos, C. \& Rossit, R.A.S (2005) Contribuições da análise comportamental para o ensino de matemática para indivíduos com deficiência mental. Em: H. Guilhardi \& N.C. Aguirre (org). Sobre Comportamento e Cognição: expondo a variabilidade. Santo André: ESETec, vol. 16, pp.230-250.

Gottschalk, R., Davidson II, W.S., Mayer, J.P., and Gensheimer, L.K. (1987). Behavioral approaches with juvenile offenders: A meta-analysis of long-term treatment efficacy. Em E.K. Morris, and C.K. Braukmann (Eds.). Behavioral Approaches to Crime and Delinquency. New York: Plenum Press.

Guilhardi, H. (2002). Análise comportamental do sentimento de culpa. Em: A.M.S.Teixeira, M.R.Assunção, R. Starling e S.Castanheira (Orgs.) Ciência do Comportamento: conhecer e avançar. Volume 1. Santo André: ESETec. Pp.173-200.

Grant, J. (1997) Conference of the Standing Conference of Educators and Trainers in Counselling and Psychotherapy. Edith Cowan University.

Haase, V. G., Freitas, P. M., Natale, L. L. \& Pinheiro, M. I. S. (2002) Treinamento comportamental de pais: uma modalidade de intervenção em neuropsicologia do desenvolvimento. Em A. M. S. Teixeira, M. R. B. Assunção, R. R. Starling \& S. S. Castanheira (Orgs.) Ciência do comportamento: conhecer e avançar. Vol.1. Santo André: ESETec.

Haapasatoa, J. e Pokelaa, E. (1998) A child rearing and a child abuse: antecedents of criminality. Journal of Agression and Violent Behavior, 4, 107-127.

Hare, R.D.(1991) PCL-R: The Hare Psychopathy Checklist - Revised. Toronto: Multi Health Systems.

Hawkins, J., Arthur, M. \& Olson, J. (1997) Community interventions to reduce risks and enhance protection against antisocial behavior. In D. Stoff, J. Breiling \& J. Maser (Orgs.) Handbook of antisocial behavior. EUA: John Wiley \& Sons.

Henggeler, S. W., Melton, G. B., \& Smith, L. A. (1992). Family preservation using multisystemic therapy: An effective alternative to incarcerating serious juvenile offenders. Journal of Consulting and Clinical Psychology, 60, 953-961.

Houaiss, A. (2001) Dicionário Houaiss de Lingua Portuguesa. SãoPaulo: Editora Objetiva.

Hoglund, C.I. \& Nicholas, K.B. (1995)Shame, guilt, and anger in college students exposed to abusive family environments. Journal of Family Violence, 10 (2), 141-157.

Horvath, A. e Luborsky, L. (1993). The therapeutic alliance and its measures. Em N. Miller, L. Luborsky, J.P. Barber, \& J. Docherty (Eds.), Psychodynamic treatment research: A handbook for clinical practice. New York: Basic Books..

Huessmann, L. R. e Eron, L.D. (1984). Intervening variables in the TV violence-aggression relation: Evidence from two countries. Developmental Psychology, 20(5), 746-777. 
Hughes, C. \& Dunn, J. (2000). Violent fantasy, antisocial behaviour, friendship, and moral sensibility in young children. Child Development, 72, 491-505.

Hutz, C.S. (2002) Situações de risco e vulnerabilidade na infância e na adolescência: aspectos teóricos e estratégias de intervenção. São Paulo: Casa do Psicólogo.

Inderbitzin, M. (2007) A look from the inside: balancing custody and treatment in a juvenile maximum-security facility. International Journal of Offender Therapy and Comparative Criminology, 51, 348-362.

Ingberman, Y. K \& Machado, S.L. (2003). O Sentimento de culpa e suas implicações para o controle coercitivo do comportamento. Proposição de Analise. Em M.Z. Brandão; F.C.S. Conte; F.S. Brandão; Y.K. Ingberman; C.B. Moura; V.M. Silva e S.M. Oliane (Orgs) Sobre Comportamento e Cognição: A historia e os avanços, a seleção por conseqüências em ação. Santo André, SP: ESETec Editores Associados.

Irvine, A.B.; Biglan, A.; Smolkowski, K.; Metzler, C.W.\& Ary, D. (1999). The Effectiveness of a Parenting Skills 'Program for Parents of Middle School Students in Small Communities. Journal of Consulting and Clinical Psychology, vol 67 (6), pp 811-825.

Jolivette, K. (2002). Transition case study. Em M.M. Kerr, \& C.M. Nelson (Eds.), Strategies for addressing behavior problems in the classroom (6a ed.). Upper Saddle River, N.J. : Merrill Prentice Hall.

Kazdin. A;E.; Siegel, T.C. \& Bass, D. (1992). Cognitive Problem- Solving Skills Training and Parent Management Training in the Treatment of Antisocial Behavior in Children. Journal of Consulting and Clinical Psychology, vol 60 (5). pp. 733- 747.

Kazdin, A.E. (1993) Methodological Issues and Strategies in Clinical Research. Washington DC: American Psychological Association.

Kellerman, J. (2002). Filhos selvagens: Reflexões sobre crianças violentas. Rio de Janeiro: Rocco.

Kohlenberg, R.J. e Tsai, M. (2001) Psicoterapia Analítica Funcional. Santo André: ESETec Editores Associados.

Kumpfer, K. L.; Alvarado, R. (2003). Family Strengthening Approaches for the Prevention of Youth Problem Behaviors. American Psychologist, 58 (6-7), pp. 457 - 465.

Kupersmidt, J.B., Coie, J.D. \& Dodge, K.A. (1990) The role of peer relationships in the development of disorder. Nova Iorque: Cambridge University Press.

La Taille, Y. (2002). Vergonha, a ferida moral. Petrópolis, RJ: Editora Vozes.

Lemgruber, J. (2001) Verdades e mentiras sobre o sistema de justiça criminal. Revista CEJ, 15 , 12-19.

Lewis, M. (1993) Self-counscious emotion: embarrassment, pride, shame and guilt. Em: M. Lewis \& J. Haviland (Eds.). Handbook of emotions. Nova Iorque: Guilford Press. 
Lindsey, L., Yun, K. e Hill, J. (2007) Antecipated Guilt as motivation to help unknown others: an examination of empathy as a moderator. Communication Research, 34, 4, 468-480

Loos, H. ; Ferreira, S. P. A. ; Vasconcelos, F. C. (1999) Julgamento Moral: Estudo Comparativo entre Crianças Institucionalizadas e Crianças de Comunidade de Baixa Renda com relação à Emergência do Sentimento de Culpa. Psicologia Reflexão e Crítica, v. 12, n. 1, p. 47-69.

Macagnan da Silva, D.F. (1999) Estilo atribucional em adolescentes infratores e não-infratores. Dissertação de mestrado não publicada, Curso de Pós-graduação em Psicologia do Desenvolvimento, Universidade do Rio Grande do Sul. Porto Alegre, RS.

Maccoby, E. \& Martin, J. (1983) Socialization in the context of the family: Parent-child interaction. In E. M. Hetherington (Org), PH. Mussen(Org Série), Handbook of child psychology: Vol. 4. Socialization, personality, and social development. New York: Wiley.

Maccoby, E.E. (1994). The role of parents in the socialization of children: a historical overwiew. In: R.D.Parke; P.A.Ornstein; J.J.Rieser \& C. Zahn-Waylers (orgs). A Century of Developmental Psychology. Washington: American Psychological Association.

Marinho, M.L. (1999). Orientação de pais em grupo: intervenção sobre diferentes queixas comportamentais infantis. Tese apresentada ao Instituto de Psicologia da Universidade de São Paulo para obtenção do grau de Doutor em Ciências (Psicologia). Área de Concentração: Psicologia Clínica.

Marinho, M.L. (2001). Subsídios ao terapeuta para análise e tratamento de problemas de comportamento em crianças: quebrando mitos. In: M. L. Marinho; V. E. Caballo (Orgs), Psicologia Clínica e da Saúde. Londrina: UEL; Granada: APICSA.

Marshall, W.L. \& Serran, G.A. (2004) The role of the therapist in offender treatment. Psychology, Crime and Law, Vol. 10, 3, pp $309-321$.

McMahon, R.J. (1996). Treinamento de Pais. In: V.E.Caballo. Manual de Técnicas de Terapia e Modificação do Comportamento. São Paulo: Santos.

McNeill, F., Batchelor, S., Burnet, R. \& Knox, J. (2005) $21^{\text {st }}$ Century Social Work: Reducing Re-offending - key practice skills. United Kingdom: Scottish Executive, Social Work Inspection Agency.

Menezes, M.V.(2006) Contingências Identidicadas nos Relatos Verbais dos Educadores Sociais em Internação com Adolescentes em um Centro de Sócio-educação. Dissertação de mestrado, Universidade Estadual de Londrina, Paraná.

Menin, M.S.S. (1985) Autonomia e heteronomia às regras escolares: observação e entrevistas na escola. Dissertação de mestrado não-publicada. Pós-graduação em Psicologia Escolar e do Desenvolvimento

Universidade de São Paulo, São Paulo, $\quad$ SP, $\quad$ Brasil.

Meyer, S.B. (1995) Quais os requisitos para que uma terapia seja considerada comportamental? Programação do IV encontro Paranaense de Psicologia. Curitiba, Paraná.

Meyer, S.B. (2004) Processos Comportamentais na Psicoterapia. Em A.C. Cruvinel, A.L.F. Dias \& Cillo, E.N. (Orgs.) Ciência do Comportamento: conhecer e avançar. Volume 4. Santo André: ESETec. 
Meyer, S.B. \& Vermes, J.S. (2001) Relação Terapêutica. Em B. Range (Org.) Psicoterapias Cognitivo-comportamentais: um diálogo com a psiquiatria. Porto Alegre: Artmed Editora.

Miranda, M. S.; Lourenço, C. A .P.; Heleno, C. T.; Bonvicini, K. C.; Käpler, K. C.; Shaefer, S. A . (2001) Pais como co- terapeutas em famílias de baixa- renda. Caderno de Resumos do X Encontro de Psicoterapia e Medicina Comportamental. Campinas: Associação Brasileira de Psicoterapia e Medicina Comportamental.

Moran, P.B., Vuchinich, S. \& Hall, N. K. (2004) Associations between types of maltreatment and substance use during adolescence. Child Abuse \& Neglect, 28, 565-574.

Morana, H.C.P. (2003) Identificação do ponto de corte para Escala PCL-R em população forense brasileira. Tese de Doutorado apresentada à Faculdade de Medicina da Universidade de São Paulo. Disponível em http://www.abpbrasil.org.br/boletim/arquivos/bol13-20071119tesehildaMorana.pdf

Myers, W.C..; Burton, P.R.S.; Sanders, P.; Donat, K.M.; Cheney, J.O.T.; Fitzpatrick, T.; Monaco, L. (2000). Project Back-on-Track at 1 Year: A Delinquency Treatment Program for Early Career Juvenile Offenders. Journal of the American Academy of Child and Adolescent Psychiatry, vol 39 (9), pp.1127-1134.

Novak, G. (1996a) Prosocial Development. In: G. Novak. Developmental Psychology: Dynamical Systems and Behavior Analysis. Reno, Nevada: Context Press.

Novak, G. (1996b) Development of Antisocial Behaviors. Developmental Psychology: Dynamical Systems and Behavior Analysis. Reno, Nevada: Context Press.

Nurco, D. e Lerner, M. (1996). Vulnerability to narcotic addiction: Family structure and funcioning. Journal of Drug Issues, vol 26, pp. 1007-1095.

OAB e Conselho Federal de Psicologia (2006) Uma amostra das unidades de internação de adolescentes em conflito com a lei. Relatório da inspeção nacional às unidadesde internação.

O’Dell, S. (1974). Training Parents in Behavior Modification: A Review. Psychological Bulletin, vol 81 (7), pp. 418-433.

Offord, D. (1997) Bridging, development, prevention and policy. In D. Stoff, J. Breiling \& J. Maser (Orgs.) Handbook of antisocial behavior. EUA: John Wiley \& Sons.

ONU (1990) Princípios das Nações Unidas para a Prevenção da Delinqüência Juvenil - (Diretrizes de Riad) Doc. das Nações Unidas n. ${ }^{\circ}$ A/CONF. 157/24 (Parte I).

Otta E. \& Bussab, V.S.R. (1998). Vai Encarar? Lidando com a agressividade. São Paulo: Editora Moderna.

Patterson, G.R., DeBaryshe, B.D. \& Ramsey E. (1989) A developmental perspective on Antisocial Behavior. American Psychologist, Vol. 44, N.2, 329-335.

Patterson, G., Reid,J \& Dishion, T. (1992). Antisocial Boys. EUA: Castalia Publishing Company. 
Patterson, G. (2002) Future extensions of the models. In J.Reid, G. Patterson \& J. Snyder. Antisocial behavior in children and adolescents: a developmental and model for intervention. APA: Washington, D. C.

Patterson, G. R. \& Stouthamer-Loeber, M. (1984). The correlation of family management practices and delinquency. Child Development, 55: 1299-1307.

Patterson, G. R. (1986). Performance models for antisocial boys. American Psychologist, 41, 432-444.

Pergher, N.K. e Sadi, H.M. (2003) Verdade e Mentira sob o ponto de vista da análise do comportamento. Em: H.M. Sadi e N.M.S. de Castro (Orgs.) Ciência do Comportamento, conhecer e avançar, Vol. 3. Santo André, SP: ESETec Editores Associados.

Perkins, D. F. \& Jones, K. R. (2004) Risk behaviors and resiliency within physically abused adolescents. Child Abuse \& Neglect, 28, 547-563.

Pettit, G.S.; Laird, R.D.; Dodge, K.A.; Bates, J.E. \& Criss, M.M. (2001). Antecedents and Behavior -Problem Outcomes of Parental Monitoring and Psychological Control in Early Adolescence. Child Development, vol 72 (2), pp.583-598.

Rangé, B. (1995) Relação terapêutica. Em B. Rangé (Org.) Psicoterapia comportamental e cognitiva de transtornos psiquiátricos. Campinas: WorkshoPsy.

Reid, J. \& Eddy, J. (2002)Interventions for antisocial behavior: overview. In J.Reid, G. Patterson \& J. Snyder. Antisocial behavior in children and adolescents: a developmental and model for intervention. APA: Washington, D. C.

Reid, J. \& Eddy, J. (2002b) Preventive efforts during the elementary school years: the linking the interests of families and teachers project. In J.Reid, G. Patterson \& J. Snyder. Antisocial behavior in children and adolescents: a developmental and model for intervention. APA: Washington, D. C.

Reid, J. B. \& Patterson, G. R. (1989) The development of antisocial behavior patterns in childhood and adolescence: Personality and aggression (Special issue). European Journal of Personality, 3: 107-119.

Reid, J. B., Patterson, G.R. \& Snyder, J. (2002) Antisocial behavior in children and adolescents: a developmental and model for intervention. Washington, D. C.: APA

Reid, J. \& Eddy, J. (1997) The prevention of antisocial behavior: some considerations in the search for effective interventions. In D. Stoff, J. Breiling \& J. Maser (Orgs.) Handbook of antisocial behavior. EUA: John Wiley \& Sons.

Reppold, C.T.; Pacheco, J. ; Bardagi, M. \& Hutz, C. (2002). Prevenção de Problemas de Comportamento e Desenvolvimento de Competências Psicossociais em Crianças e Adolescentes: Uma Análise das Práticas Educativas e dos Estilos Parentais. In: C. Hutz (org). Situações de Risco e Vulnerabilidade na Infância e na Adolescência: Aspectos Teóricos e Estratégias de Intervenção. São Paulo: Casa do Psicólogo.

Reppold, C.T., Pacheco, J. \& Hutz, C. (2005) Comportamento Agressivo e Práticas Disciplinares Parentais. Em C. Hutz (Org.) Violência e Risco na Infância e Adolescência: pesquisa e intervenção. São Paulo: Casa do Psicólogo. 
Rodgers, C. S., Lang, A. J., Laffaye, C., Satz, L.E, Dresslhaus, T.R. \& Stein, M.B. (2004) The impact of individual forms of childhood maltreatment on health behavior. Child Abuse \& Neglect, 28, 575-586.

Rosenblatt, A. e Rosenblatt, J.A. (1998) Perpetrators of Physical Abuse. Em: N.N. Singh (Org.) Application in Diverse Populations. Oxford, UK: Pergamon Press.

Rosenfarb, I.S. (1992) A behavior analytic interpretation of the therapeutic relationship. The Psychological Record, 42, 341-354.

Ross, A. O. (1979) Distúrbios psicológicos na infância. São Paulo: Mcgraw-Hill do Brasil.

Rutter, M. (1997) Antisocial behavior: developmental psychopathology perspectives. In D. Stoff, J. Breiling \& J. Maser (Orgs.) Handbook of antisocial behavior. EUA: John Wiley \& Sons.

Salla, F.(1999) As prisões em São Paulo: 1822-1940. São Paulo: Annablume/Fapesp.

Sanders, M.R.; Markie-Dadds, C.; Tully, L.A.; Bor, W. (2000). The Triple P- Positive Parenting Program: a comparison of enhanced, standard an self- directed behavioral family intervention for parents of Children With Early Onset Conduct Problems. Journal of Consulting and Clinical Psychology, vol 68 (4), pp. 624-640.

Santos, G.E.S.(2001) Proposta de Intervenção com Pais Agressores: uma Perspectiva em Educação Especial. Dissertação defendida no Programa de Pós Graduação em Educação Especial. São Carlos: UFScar.

Schlinger, Jr. H. D. (1995) A behavior analytic view of child development. New York: Plenum Press.

Sénéchal-Machado, A. M. (2002) Sobre terapia comportamental: questões freqüentes da comunidade. Em: A. M. S. Teixeira; M. R. B. Assunção; R. R. Starling; S. S. Castanheira. (Orgs.). Ciência do comportamento: conhecer e avançar. 1a ed. Santo André/SP: ESETec Editores Associados.

Serafim, A. P. (2005) Correlação entre ansiedade e comportamento criminoso: padrões de respostas psicofisiológicas em homicidas. Tese apresentada ao Programa de Pós-graduação em Fisiopatologia Experimental da Faculdade de Medicina da Universidade de São Paulo para obtenção do título de Doutor em Ciências.

Serketich, W.J. \& Dumas, J.E. (1996). The Effectiveness of behavioral parent training to modify antisocial behavior in children: A Meta analysis. Behavior Therapy, 27, 171- 186.

Silvares, E. F. M. \& Baraldi, D. M. (2003) Treino de habilidades sociais em grupo com crianças agressivas, associado à orientação dos pais: análise empírica de uma proposta de atendimento. Em A. Del Prette \& Z.A.P. Del Prette (Orgs.) Habilidades Sociais, Desenvolvimento e Aprendizagem: questões conceituais, avaliação e intervenção. Campinas: Alínea Editora.

Simons, R.L., Wu, C., Lin,K., Gordon, L. \& Conger, R.D. (2000) A cross-cultural examination of the link between corporal punishment and adolescent antisocial behavior. Criminology, 38 (1), 47-79.

Sistema Nacional de Atendimento Socioeducativo (2006) Relatório Nacional. 
Skinner, B.F. (1953/ 1974) Ciência e Comportamento Humano. São Paulo: Martins Fontes.

Skinner, B.F. (1957/ 1978) O comportamento verbal. São Paulo: Editora Cultrix.

Smith, D. L. (1953/ 2006) Por que mentimos: os fundamentos biológicos e psicológicos da mentira. Tradução de Why we lie. Marcello Lino. - Rio de Janeiro: Elsevier.

Snyder, J. e Patterson, G.R. (1987) Family interactions and delinquent behavior. Em H.C. Quay (Ed.) Handbook of juvenile delinquency. USA: John Wiley and sons.

Snyder, J. \& Stoolmiller, M. (2002) Reinforcement and coercion mechanisms in the development of antisocial behavior: the family. In J.Reid, G. Patterson \& J. Snyder. Antisocial behavior in children and adolescents: a developmental and model for intervention. APA: Washington, D. C.

Sokol-Katz, J. S., Dunham, R. G., and R. S. Zimmerman. (1997) The relationships between parental attachment/family structure and adolescent deviant behavior. Journal of Adolescence.

Southam-Gerow, M. \& Kendall, P. (1997) Parent-focused and cognitive-behavioral treatments of antisocial youth. In D. Stoff, J. Breiling \& J. Maser (Orgs.) Handbook of antisocial behavior. EUA: John Wiley \& Sons.

Sposato, K. e Pereira, T.M. (2004) Foco desajustado: Visão da imprensa sobre menores infratores é distorcida. Revista Consultor Jurídico.

Stattin, H e Kerr, M. (2000). Parental Monitoring: A Reinterpretation. Child Development, vol $\underline{71}$ (4), p. 1072-1085.

Steinberg, L. (1990) Interdependence in the family: autonomy, conflict, an harmony in the parent-adolescent relationship. In: S.S. Feldmam e G.R.Elliot (orgs). At the threshold: the developing adolescent. Cambridge, MA: Harvard University Press.

Steinberg, L. \& Darling, N. (1993) Parental style as context: an integrative model. Psychological Bulletin, 113, 487-497.

Steinberg, L., Darling, N., Dornbush, S., Lamborn, S., Mounts, N. (1994) Over-time changes in adjustment and competence among adolescents from authoritative, authoritarian, indulgent and neglectful families. Child Development, 65, 754-770.

Steinberg, L., Darling, N., Fletcher, A., Dornbush, S. (1995) The company they keep: relation of adolescents adjustment and behavior to their friends perceptions of authoritative parenting in the social network. Developmental Psychology, Vol.31(2), 300-310.

Straus M.A.(1994) Beating the devil out of them: corporal punishment in American families. San Francisco, USA: Jossey-Bass-Lexington Books.

Stoff, D.M., Breiling, J. e Maser, J. (1997) Handbook of Antisocial Behavior. Canada: Wiley.

Teixeira, A.M.S. (2002) A individualização do ensino em uma pré-escola: uma intervenção comportamental na educação infantil. Em A.M.S. Teixeira et. al(Orgs) Ciência e Comportamento: conhecer e avançar. Santo André: ESETec.

Thompson, D.W. (1998) Street Gangs. Em: N.N. Singh (Org.) Application in Diverse Populations. Oxford, UK: Pergamon Press. 
Thornberry, T. \& Krohn, M. (1997) Peers, drug use and delinquency. In D. Stoff, J. Breiling \& J. Maser (Orgs.) Handbook of antisocial behavior. EUA: John Wiley \& Sons.

Timmerman, I.G.H. e Emmelkamp, P.M.G. (2005) The Effects of Cognitive-behavioral treatment for forensic inpatients. International Journal of Offender Therapy and Comparative Criminology, 49: 590-606.

Tolan, P. \& Gorman-Smith, P. (1997) Treatment of Juvenile delinquency: between punishment and therapy. In D. Stoff, J. Breiling \& J. Maser (Orgs.) Handbook of antisocial behavior. EUA: John Wiley \& Sons.

Tracy, J.L. \& Robins, R.W. (2006) Appraisal Antecedents of Shame and Guilt: Support for a Theoretical Model. Personality and Social Psychology Bulletin, Vol. 32, No. 10, 1339-1351.

Vien, A. e Beech, A.R. (2006) Psychopathy: theory, measurement, and treatment. Trauma, Violence, \& Abuse, Vol. 7, No. 3, 155-174.

Wacquant, L. (1999) Crime e castigo nos Estados Unidos: de Nixon a Clinton. Revista Sociologia Política, 13, p. 39-50.

Waxler, C. Z. e Yarrow, M. R., (1979). Dimensions and correlates of prosocial behavior in young children. Child Development, 47, 118-125.

Webster- Stratton, C. (1998). Preventing Conduct Problems in Head Start Children: Strengthening Parenting Competencies. Journal of Consulting and Clinical Psychology, vol 66 (5), pp. 715-730.

Webster- Stratton, C. ; Kolpacoff, M. \& Hollinsworth, T. (1988). Self- Administrated Videotape Therapy for Families with Conduct- Problem Children: Comparison with Two Cost- Effective Treatments and a Control Group. Journal of Consulting and Clinical Psychology, vol 56 (4), pp. 558- 566

Webster-Stratton, C. (1994). Advancing Videotape Parent Training: A comparison Study. Journal of Consulting and Clinical Psychology, pp. 583-593.

Widom, 1989.

Wiese, M.R.R. (1992). A Critical Review of Parent Training Research .Psychology in the Schools, vol 29, pp. 229- 236.

Wilson, J.P.; Drozdek, B. \& Turkovic, S. (2006). Posttraumatic Shame and Guilt. Trauma Violence Abuse; 7; 122.

Winsor, W.M.H., Catellier, D. \& Kotch, J.B. (1999) Maternal disciplinary practices in an at-risk population. Archives of Pediatrics \& Adolescent Medicine, 153 (9), 927-936.

Wolchick, S.A.; Sharlene, A.; West, S.G.; Sandler, I.N.; Tein, J.Y.; Coatsworth, D.; Lengua, L.; Weiss, L.; Anderson, E.R.; Greene, S.M.; Griffin, W.A.(2000). An Experimental Evaluation of Theory- Based Mother and Mother- Child Programs for Children of Divorce. Journal of Consulting and Clinical Psychology, vol 68 (5), pp. 843-856.

Wood, I.K. (1998) Violent and Chronic Offenders. Em N.N. Singh (Org.) Application in Diverse Populations. Oxford, UK: Pergamon Press. 
Wright, J.P. e Cullen, F.T. (2001) Parental Efficacy and Delinquent Behavior: Do Control and Support Matter? Criminology, V. 39(3), pp. 677-705.

Yano, Y e Meyer, S.B. (2003) Tratamento padronizado e individualizado. In: M. Z. S. Brandão; F.C.S. Conte; F.S.Brandão; Y.K. Ingberman; C.B.Moura; V.M. Silva; S. Oliane. (Org.). Sobre Comportamento e Cognição. A história e os avanços, a seleção por conseqüências em ação. 1 ed. Santo André: ESETec, 2003, v. 11, p. 126-129.

Yano, Y. (2003) Tratamento Padronizado e Individualizado no Transtorno do Pânico. Tese de Doutorado em Psicologia Clínica, Instituto de Psicologia da Universidade de São Paulo.

Yau-Fai Ho, D.; Fu, W. \& Ng, S.M. (2004). Guilt, Shame and Embarrassment: Revelations of Face and Self. Culture Psychology; 10; 64.

Zamignani, D.R. e Meyer, S.B. (2007) Sistema multidimensional de categorização de comportamentos da interação terapêutica. Universidade de São Paulo.

Zamignani, D. R. (2007). O desenvolvimento de um sistema multidimensional para a categorização de comportamentos na interação terapêutica. Tese de Doutorado. Universidade de São Paulo. 
ANEXOS 
ANEXO 1

ATIVIDADES DE ESCOLARIZAÇÃO

As atividades de escolarização se dão dentro da própria unidade (CEEBJA - Centro de Educação Básica para Jovens/ São Francisco; estabelecidos a partir do termo de Cooperação firmado entre a Secretaria de Estado da Educação e a Secretaria de Estado da Criança e Assuntos da Família), com corpo de professores contratados pelo estado. Os adolescentes fazem testes para avaliação do nível de desempenho escolar. Os documentos dos adolescentes referentes à escolarização são atualizados pelas professoras que devem entrar em contato com as escolas anteriores para organizar a documentação. Para o desinternamento as professoras deverão matricular o adolescente na escola mais próxima de sua futura moradia e levá-lo até a orientadora para apoiá-lo no reingresso escolar. O procedimento de escolarização divide-se em: alfabetização, ensino fundamental e médio. Também são ofertadas aulas de reforço com voluntários pré-selecionados.

Com o mínimo necessário de escolarização e de comportamentos adequados os adolescentes são encaminhados para cursos de profissionalização na unidade ou em instituições conveniadas que oferecem cursos de mecânica básica, eletroeletrônica, informática, cabeleireiro, eletricista e padeiro. O objetivo da qualificação profissional é possibilitar o encaminhamento para emprego na ocasião do desinternamento favorecendo um meio de sustento. 


\section{ANEXO 2}

Quadro 1. Atividades do programa para Adolescentes Infratores de Alto-risco.

\section{Leitura de Estória}

\section{Objetivos}

-Desenvolver a discriminação sobre a conseqüência negativa (interrupção da atividade e retorno imediato à cela) para comportamentos inadequados, tais como zombar, ironizar, xingar, interromper a atividade, reclamar.

-Desenvolver a discriminação sobre a conseqüência positiva (permanência do educador, elogios às atividades, obtenção de permissão para fazer um telefonema para família) para comportamentos adequados, tais como, realizar a tarefa com ou sem entusiasmo, prestar atenção às instruções, cuidar do material utilizado na tarefa.

-Desenvolver o gosto pela leitura, melhorar a compreensão e interpretação do texto, aumentar o vocabulário, fazer resumo do livro positivas e negativas dos personagens.

-Desenvolver a discriminação que existe um período de cinco minutos dedicados à reclamação durante a atividade.

-Avaliar se o adolescente apresenta emoções adequadas ao conteúdo do texto. lido, identificando as características

\section{Procedimento}

O educador convida o adolescente para ouvir um trecho de uma história que será lida em capítulos. Antes de iniciar a atividade é dito ao adolescente que terá um tempo para fazer suas reclamações. Ouve-se e anota-se. Após cinco minutos o educador diz que o tempo para reclamações acabou e que irão iniciar a atividade de leitura.

Caso o adolescente emita comportamentos agressivos (palavrões, desacate o educador, etc) ou irônicos (debochando da atividade) o educador interrompe a atividade dizendo: "percebo que você não está interessado nesta atividade, então você voltará para a cela e outro dia continuamos a atividade". Se houver qualquer tipo de tumulto o educador que faz a segurança é chamado e o adolescente é levado para a cela imediatamente. Esta atividade poderá também ser desenvolvida dentro da própria cela.

Nas sessões seguintes pede-se ao adolescente para que leia o trecho da estória e interprete o que for lido.

O educador deve anotar na ficha do adolescente: mostrou emoções adequadas ao conteúdo da estória (riu se era engraçado, expressou tristeza diante de um fato triste, ou se leu os acontecimentos sem alterar a emoção na face ou voz) se prestou atenção ou estava desatento, suas expressões faciais e corporais, se interrompeu a leitura e o que disse.

Ao final da estória será proposta uma sessão para contar uma síntese da estória, personagens "do bem" e do "mal", quais as características, e fazer um desenho representativo da estória.

\section{Jogo \\ Objetivos}

-Desenvolver habilidade para aceitar perder e ganhar em um jogo.

-Desenvolver o comportamento de seguir regras.

\section{Avaliação}

Avaliação Positiva:

-Solicitou outros livros para leitura;

-Utilizou o tempo da atividade para ler, sem interrupção;

-Leu com a emoção adequada ao texto;

-Interpretou corretamente o texto; -Fez o resumo do livro, identificando corretamente os personagens positivos e negativos; -Reduziu o período de reclamação;

\section{Procedimento}

-O educador propõe um jogo: trilhas, damas ou dominó. Se o adolescente aceitar, pede a ele que explique as regras do jogo. Se estiverem corretas iniciam o jogo, caso contrário, explica as regras e pede a ele para repetir e então iniciam o jogo. Caso não tenham completado a partida dentro do prazo do atendimento verifica-se

\section{Avaliação}

\section{Avaliação Positiva:}

Seguiu as regras do jogo;

Aceitou a derrota;

Vibrou com a vitória.

Sugeriu novas formas de jogar. 


\section{Escrever cartas para a família} Objetivos

-Desenvolver o relacionamento familiar.

-Despertar as emoções em relação à família, tais como, saudades, culpa, respeito, raiva, desprezo. quem estava ganhando até aquele momento e se for o adolescente o educador o parabeniza pelo resultado, se for o educador pede a ele que faça o mesmo e diz que terão outras chances para ele poder ganhar.

-Se o adolescente pegar uma das peças do jogo pede-se a ele que devolva, se insistir em não devolver chama-se o educador que faz a segurança para retirar a peça e leválo á cela. O educador deve ficar atento.

\section{Procedimento}

-O educador diz: "Hoje você pode escrever uma carta para alguém de sua família. Pode escolher a pessoa". -Pede ao adolescente para lembrar as regras da unidade sobre cartas (não pode usar códigos, gírias, fazer desenhos obscenos, de armas, etc). Depois de verificar que a resposta está correta entrega papel e caneta para ele. Coloca-se a disposição para auxiliá-lo com alguma palavra que ele tenha dificuldade em escrever. Ao final, lê a carta e se estiver dentro das normas a recebe para ser enviada à família.

-Se as emoções do adolescente em relação à família forem negativas pode-se sugerir a ele que escreva a carta, mesmo sem mandar, para que desabafe, descarregue a emoção, e possa começar a conviver melhor com ela. A carta pode ser queimada pelo adolescente, junto com o educador, na seqüência.

Redações: escola, bairro, amigos, infância, família, a maior alegria, a maior tristeza, e o futuro Objetivos

Recuperar lembranças da primeira infância, alternativas à vida infracional.

Melhorar a capacidade de comunicação escrita do adolescente. Desenvolver a capacidade de expressar emoções, tanto escrita ou verbal, como de forma não verbal (através do choro).

\footnotetext{
Argila

Objetivos

Descarregar a raiva e outras emoções;
}

\section{Procedimento}

O educador diz: "Hoje gostaria que você escrevesse uma redação sobre mostrar que entendeu a tarefa dando exemplos do que escreverá. Depois de verificar que a resposta está correta entrega papel e caneta para ele. Coloca-se a disposição para auxiliá-lo com alguma palavra que ele tenha dificuldade em escrever. Ao final, lê a redação, elogia o trabalho realizado e diz que irá guardar na pasta dele.

Estas redações serão analisadas de forma a informarem à equipe técnica a evolução do adolescente. Esperase que ao longo da escrita das redações o adolescente apresente melhor suas emoções, fale sobre elas com a equipe e também externe suas emoções (chorando, por exemplo).

\section{Procedimento}

$\mathrm{O}$ educador deve entregar uma porção de argila e dizer ao ....". Pede ao adolescente para

\section{Avaliação}

Avaliação Positiva:

-Conversou com a equipe sobre suas relações familiares;

-Demonstrou emoção em relação à família;

-Mostrou interesse pelas pessoas da família através das cartas (sem falar sobre atividades infratoras).

\section{Avaliação \\ Avaliação Positiva:}

-Conversou com a equipe sobre sua história de vida (não a infracional). -Expressou emoções referentes às suas lembranças.

\section{Avaliação}

Observar se ele relaxa durante a atividade; 
Relaxar

Expressar emoções;

Criar objetos ou pessoas e falar sobre eles.

\section{A Ilha}

Objetivos

Avaliar a rede de relações familiares e de amizade.

\section{Feijãozinho}

Objetivos

Demonstrar cuidado por algo.

Fábulas

Objetivos

Desenvolver comportamento moral adolescente que ele deve primeiramente amassar bem até que fique com boa textura, com a força que desejar. Em seguida sugerir que ele faça (construa) algo que lhe vier à cabeça, ele poderá construir o que quiser e souber. Deixá-lo a vontade para trabalhar, interferindo o mínimo possível. Elogiar o fato dele estar amassando a argila e qualquer tentativa de construção de objetos. Não importa se não sabe fazer, o educador deve incentivar o adolescente a fazer objetos fáceis no inicio, porém deve deixar que ele faça o que quiser e que fale durante o processo sem que o educador interfira, deve apenas ouvir.

$\mathrm{O}$ educador deve ouvir e registrar tudo que $\mathrm{o}$ adolescente falar $\mathrm{e}$ principalmente observar as faces e postura (relaxada ou tenso, no inicio e no fim da sessão).

O Educador deve estar atento sobre a quantidade de argila que der ao adolescente e quantidade que receberá no final do atendimento. Nesta fase ainda o adolescente não poderá levar o produto de seu trabalho para a cela.

\section{Procedimento}

O educador conta a seguinte estória" Faz de conta que você está numa ilha deserta com mais 10 pessoas. Nesta ilha não há o que comer nem beber. Portanto, se ficarem na ilha certamente irão morrer. Você encontra um barco que só cabe seis pessoas (você e mais cinco) e como é o líder do grupo tem direito de escolher cinco pessoas que irão embora com você e cinco que ficarão".

O educador entrega uma folha com lápis para $\mathrm{o}$ adolescente $\mathrm{e}$ diz "Desenhe o barco a ilha e coloque dentro do barco o nome das pessoas que irão se salvar e as que irão ficar".

\section{Procedimento}

Entrega-se ao adolescente um copo de plástico com algodão e um grão de feijão e pede-se a ele que cuide do feijãozinho para que ele cresça, molhando, levando para o sol, etc.

\section{Procedimento}

$\mathrm{O}$ educador irá ler ou pedir ao adolescente que leia uma fábula. Quando terminar a leitura deve-se pedir ao adolescente que interprete a fábula, dizendo qual o moral da história. $\mathrm{O}$ educador poderá ajudar o adolescente a compreender o
Observar se ele usa a argila para descarregar raiva;

Observar se ele constrói objetos ou pessoas e fala sobre eles;

Corpo e faces relaxadas no final da sessão indicam progresso na liberação das emoções;

$\mathrm{O}$ adolescente que conversa sobre suas emoções "estou com raiva, isto está me ajudando a me livrar dela", por exemplo, é um bom sinal do efeito positivo da atividade.

\section{Avaliação}

\section{Avaliação Positiva:}

-Expressou os motivos que levaram a deixar ou levar as pessoas;

-Referiu-se (lembrou) a pessoas da família (não apenas os companheiros de cela).

\section{Avaliação}

Avaliação Positiva:

Verificar se o feijão se desenvolveu. Verificar se ele molha, leva para tomar sol, se conversa com a planta.

\section{Avaliação}

Será registrado se o adolescente compreendeu totalmente, parcialmente ou não compreendeu o moral da história. 
Dia de Visita da Família

significado da história.

Serão feitas de forma descritiva, registrando-se o comportamento não verbal entre os membros da família: formas de abraço, de estar junto, de se olharem, de sorrirem um para o outro, de ficarem próximos ou distantes.

Entrevista com o membro da família

Investigar dois tópicos: a) a história de infração: quais os primeiros crimes cometidos pelo adolescente, com que idade, contra quem, descrição completa; b) Cuidados na primeira infância: quem cuidou desde bebê, as condições deste cuidado, feito pela mãe, por vizinhos, se apanhava, se ficava sozinho, se ficava com irmãos mais velhos, se viveu no orfanato.

As entrevistas podem ser feitas nos dias das visitas ou por telefone. Se possível, com vários membros da família. 
ANEXO 3

\section{Procedimento de Segurança e Medidas Disciplinares}

Os procedimentos de segurança são específicos a comportamentos inadequados dos adolescentes e devem ser aplicados sempre que as ocorrências forem observadas. Os comportamentos inadequados mais comuns e os respectivos procedimentos são:

a) Depredação da cela

Retirar o adolescente da cela no primeiro sinal de destruição de algo na cela e colocá-lo em outra cela algemado pelas mãos na porta. Esperá-lo parar de gritar, ameaçar, chutar, etc e dizer "se você ficar quieto nos próximos 15 minutos iremos tirar as algemas"; retirar as algemas e caso ele volte a perder o controle, algemá-lo novamente e repetir o procedimento até ele se acalmar. Se ocorrer próximo ao horário da refeição, não entregar a refeição e avisar que esta estará a disposição e será entregue meia hora depois dele ter se acalmado e pedido desculpas. No próximo, horário de refeição oferecer a comida normalmente.

b) Agressão física à equipe

Imobilizar e algemá-lo na porta da cela esperar ele se acalmar e dizer "se você ficar quieto nos próximos 15 minutos iremos tirar as algemas"; retirar as algemas e caso ele volte a perder o controle, algemá-lo novamente e repetir o procedimento até ele se acalmar. Anotar na ficha de avaliação e quando ele se acalmar mostrar que deve desculpas aos educadores. Se ocorrer próximo ao horário da refeição, não entregar a refeição e avisar que esta estará a disposição e será entregue meia hora depois dele ter se acalmado e pedido desculpas. No próximo,horário de refeição oferecer a comida normalmente.

c) Agressão verbal à equipe

Ignorar e anotar na ficha de avaliação. Quando ele se acalmar mostrar que deve desculpas aos educadores.

d) Greve de fome

Dizer que é seu direito não comer e que o médico será chamado para assisti-lo, porém que não fará nada, pois é preciso respeitar o direito de não comer. Oferecer a comida nos horários normais.

e) Destruição de colchão ou roupa de cama

Ao primeiro sinal de destruição, retirar todo o material da cela (colchão, travesseiro, roupa de cama e cobertor) e avisar que serão devolvidos assim que ele se acalmar e prometer não estragar nada e pedir desculpas aos educadores. Se ocorrer próximo ao horário da refeição, não entregar a refeição e avisar que esta 
estará a disposição e será entregue meia hora depois dele ter se acalmado e pedido desculpas. No próximo horário de refeição oferecer a comida normalmente.

f) Descontrole comportamental (gritos, chutes na porta, arremessar comida ou urina/fezes, etc).

Esperar passar cinco minutos sem batidas ou gritos e dizer para o adolescente "Fulano, gosto mais de você quando você esta calmo e bem comportado, parabéns, continue assim", se afastar. Se ele reiniciar o barulho, se afastar e não dar atenção até que ele fique novamente cinco minutos quieto e repetir a frase, com calma e carinho. Depois ir aumentando o período em que ele está quieto e a cada meia hora passar e dizer "oi Fulano, que bom que você está calmo, mais tarde passo aqui para conversarmos ou para fazermos a atividade, estou gostando de seu comportamento". Sempre que ele estiver fazendo barulho não deve receber atenção.

Se ocorrer próximo ao horário da refeição, não entregar a refeição e avisar que esta estará à disposição e será entregue meia hora depois dele ter se acalmado e pedido desculpas. No próximo, horário de refeição oferecer a comida normalmente.

Pedir aos adolescentes que estiverem calmos para interferirem junto aos outros pedindo que parem com o barulho.

\section{MEDIDAS DISCIPLINARES}

São medidas educativas adotadas pela unidade em decorrência de comportamentos inadequados apresentados pelo adolescente prejudiciais ao seu convívio na unidade. Estas medidas se caracterizam pela restrição do adolescente ao seu alojamento individual. Durante a execução da medida disciplinar o adolescente poderá sair somente para o atendimento psicológico e para atendimento médico ou odontológico emergenciais, se necessário. A necessidade de atendimento em caráter de emergência é primeiramente avaliada pelo educador. Se julgar necessário este chamará a enfermeira, que fará contato com o médico.

A medida disciplinar deve ser diferenciada da contenção, que é um procedimento físico que visa cessar, interromper um comportamento agressivo do adolescente.

\section{Níveis da Medida Disciplinar}

A MD será aplicada quanto o adolescente cometer atos nos seguintes níveis de gravidade:

1. Leve: Recusar-se a entrar no alojamento, recusar-se a fechar a portinhola, chutar a porta, xingar funcionários, gritar coisas inadequadas, não tomar banho, não cortar a unha ou o cabelo e não arrumar a cela. Importante: Quando o 
adolescente diz que não vai entrar no alojamento o educador informa que as demais atividades do dia já estão perdidas e dá 5 minutos para o adolescente entrar espontaneamente. Caso isto não aconteça o adolescente recebe a medida de permanência no alojamento por 24 horas.

Conseqüência: o adolescente fica 24 horas em seu alojamento, sem atividades. Depois de avisado da aplicação da MD se o adolescente permanecer com o comportamento inadequado será aplicada a MD de permanência de 3 dias no alojamento sem atividades.

2. Média: ameaçar verbalmente que vai agredir, jogar objetos ou líquidos na equipe; rasgar roupa de cama, colchão, travesseiro, quebrar objetos de uso pessoal ou material de consumo da unidade, não devolver roupa quando solicitado, estar com roupas diferentes do uniforme dentro da unidade.

Conseqüência: o adolescente permanecerá em seu alojamento por 7 dias e além disto é retirado o colchão das 8 às 19 horas. Caso no período noturno o adolescente estrague o colchão ficará sem colchão até o final da medida.

3. Grave: quebrar paredes ou depredar patrimônio da unidade, estar com estoque e tentar dar chute, soco, etc.

Conseqüência: o adolescente permanecerá em seu alojamento por 15 dias e além disto é retirado o colchão das 8 às 19 hs; nas primeiras 24 horas o adolescente ficará algemado em sua cela (algemas de mão e marca-passo ligados). Caso no período noturno o adolescente estrague o colchão ficará sem colchão até o final da medida. Nesta medida o boletim de ocorrência ${ }^{20}$ deverá ser feito tão logo quanto possível, e este procedimento é comunicado ao mesmo tempo em que se comunica a MD.

Quando houver buraco entre celas, ambos adolescentes receberão a medida.

4. Gravíssima: agredir fisicamente alguém provocando lesão.

Conseqüência: o adolescente permanecerá em seu alojamento por 21 dias e além disto é retirado o colchão das 8 às 19 horas; nas primeiras 24 horas o adolescente ficará algemado em sua cela (algemas de mão e marca-passo ligados). Caso no período noturno o adolescente estrague o colchão ficará sem colchão até o final da medida. Nesta medida o boletim de ocorrência também deverá ser feito tão logo quanto possível, e este procedimento é comunicado ao mesmo tempo em que se comunica a MD.

\footnotetext{
${ }^{20}$ Para fazer o B.O. a PM deverá ser chamada para fazer a escolta do adolescente, que segue até o distrito apropriado acompanhado também por um educador designado pelo coordenador de equipe.
} 
O algemamento de mãos e pés acontece sempre que haja algum tipo de reação física do adolescente contra a integridade física ou do ambiente (paredes, cama, vaso sanitário, etc.). Se durante a execução de uma MD leve ou média o adolescente reagir agressivamente ou depredar o patrimônio será imediatamente alterada a gravidade da $\mathrm{MD}$, passando a valer a de maior gravidade.

\section{Aplicação da Medida Disciplinar}

A relação dos adolescentes em MD deve ser apresentada à direção diariamente pelo coordenador da equipe de segurança para que os profissionais voluntários que atendem na Unidade sejam informados sobre a restrição à atividade naquele período.

Nos níveis de gravidade "leve e médio" a medida poderá ser aplicada pela equipe de educadores de plantão, ser registrada no livro de ocorrência com a especificação dos motivos que levaram a aplicação da medida e ser comunicada no quadro de avisos para que todos na unidade tomem ciência. É indispensável que haja a assinatura do coordenador da equipe de segurança na notificação da medida. Caso o procedimento seja tomado à noite os plantonistas devem informar o coordenador no plantão seguinte para que ele possa responder conjuntamente pelas MDs tomadas.

No nível de gravidade "Grave" o coordenador da equipe de educadores convocará a comissão disciplinar para tomada de decisão e um técnico da equipe informará ao adolescente o motivo e período de em que ele estará sob Medida Disciplinar.

No nível de gravidade "gravíssima" o coordenador da equipe convocará a comissão disciplinar e o Diretor da Unidade para tomada de decisão e o diretor da unidade informará ao adolescente o motivo, os procedimentos e período no qual ele estará sob Medida Disciplinar.

A comissão das medidas disciplinares é composta da seguinte maneira: Coordenador de educadores do plantão, Técnico (psicólogo, assistente social, terapeuta ocupacional ou enfermeiro), Educador (pedagogo ou professor) e a pessoa envolvida no incidente. 


\section{TERMO DE CONSENTIMENTO}

Eu, Paula Inez Cunha Gomide, coordenadora do Programa para Adolescentes Infratores de Alto-risco, assessora do governo do estado do Paraná para assuntos da infância e adolescência, autorizo o adolescente:

R.G.

que se encontra sob a tutela do estado internado cumprindo medida socioeducativa em uma unidade especializada para infratores de alto-risco, a participar da pesquisa clínica conduzida pela Psicóloga Giovana Veloso Munhoz da Rocha, psicoterapeuta voluntária no Programa.

É de meu conhecimento, assim como asseguro que será do conhecimento dos adolescentes, que os atendimentos psicoterápicos realizados pela psicóloga Giovana fazem parte de um estudo por ela realizado como parte de suas atividades de doutorado, que realiza no Instituto de Psicologia da Universidade de São Paulo, em Psicologia Clínica. Há ciência de que o estudo refere-se ao processo terapêutico especificamente com a população de infratores, tendo finalidade maior de descrição e compreensão do processo e avaliação dos resultados.

As sessões serão gravadas em áudio com objetivo de registros de dados para análise pela pesquisadora, com o conhecimento dos adolescentes, que poderão solicitar o desligamento do aparelho durante os atendimentos se assim desejarem. Os procedimentos de segurança da unidade de internamento devem ser de conhecimento da psicóloga, que deverá se comportar de acordo com eles durante toda sua estada na unidade. Há concordância quanto à confidencialidade e sigilo assegurados em qualquer processo de psicoterapia, de acordo com o Código de Ética do Psicólogo. Os dados coletados serão usados apenas para fins científicos, e jamais para fins jurídicos. 
Fica acordado que não há qualquer tipo de remuneração ou auxílio financeiro para ambas as partes. Também fica estabelecido que será possível interromper o processo caso questões relativas a segurança da unidade ou da própria profissional e do adolescente esteja em risco.

Curitiba, 24 de Fevereiro de 2005.

Paula Inês Cunha Gomide

Pesquisadora

Psicóloga Giovana Veloso Munhoz da Rocha CRP 08/6848-7

Endereço comercial: Av. Candido Hartmann 570 cj 221 - Bigorrilho

Telefones: 41 - 3022-2747

E-mail: gicarocha@hotmail.com 
Como a presente pesquisa tem foco também nas práticas educativas (Gomide, 2006) utilizadas pelo terapeuta, as categorias de análise empregadas para o comportamento do psicoterapeuta podem ser interpretadas e discutidas de acordo com as prováveis práticas educativas correspondentes. Desta forma buscou-se ilustrar através dos conhecidos comportamentos do terapeuta quais as práticas educativas correspondentes, dado que será relevante na análise das sessões e na discussão dos resultados.

No próximo quadro serão exemplificadas a partir do IEP (Gomide, 2006) possíveis comparações entre as práticas educativas e comportamento do terapeuta.

Categoria IEP

Quando saio conto a ela espontaneamente aonde eu vou.

Ela pergunta como foi meu dia na escola e me ouve atentamente.

Quando estou triste ou aborrecido (a), ela se interessa em me ajudar a resolver o problema.

Mesmo quando está ocupada ou viajando, me telefona para saber como estou.

Após uma festa ela quer saber se me diverti.

Ela estabelece regras (o que pode e o que não pode ser feito) e explica as suas razões sem brigar

Ela me ensina a devolver objetos ou dinheiro que não me pertencem.

Se eu colar na prova ela me explica que é melhor tirar nota baixa do que enganar a professora ou a mim mesmo (a).

Quando estrago alguma coisa de alguém, ela me ensina a contar o que fiz e pedir desculpas. programas de TV que mostrem os efeitos negativos do uso de drogas.

Ela conversa comigo sobre o que é certo ou errado no comportamento dos personagens dos filmes e dos programas de TV.

Ela conversa sobre meu futuro trabalho mostrando os pontos positivos ou negativos da minha escolha.

Comportamento do Terapeuta

A terapeuta reforça o comportamento do adolescente de fornecer informações sobre sua rotina espontaneamente.

Pergunta como foi a semana do adolescente e ouve atentamente.

Demonstra interesse em ajudar a resolver problemas quando o adolescente está triste ou aborrecido.

Quando o terapeuta viaja ou não pode atender $\mathrm{o}$ adolescente, telefona para a unidade para saber como ele está.

Após atividades de lazer o terapeuta quer saber se o adolescente se divertiu.

$\mathrm{O}$ terapeuta segue as normas gerais da unidade e estabelece regras (o que pode e o que não pode ser feito em psicoterapia) e explica as suas razões sem brigar.

O terapeuta orienta sobre a devolução de objetos ou dinheiro que não pertencem ao adolescente.

O terapeuta orienta sobre comportamentos adequados na escola, por exemplo quando o adolescente cola, explica que não é correto enganar o professor.

O terapeuta orienta a falar a verdade e pedir desculpas quando o adolescente faz alguma coisa inadequada.

O terapeuta orienta e promove a leitura de livros, revistas e programas de TV que mostrem os efeitos negativos do uso de drogas e de outros comportamentos inadequados, principalmente os comportamentos anti-sociais.

A terapeuta promove discussões sobre o que é certo e errado no comportamento dos personagens de filmes e programas de TV.

A terapeuta promove conversas sobre o futuro acadêmico e profissional, promovendo escolhas e mostrando os pontos positivos e negativos da escolha do adolescente. 
Quando faço algo errado, a punição de minha mãe é mais severa dependendo de seu humor.

Quando ela está alegre não se importa com as coisas erradas que eu faça.

Ela me castiga quando está nervosa; assim que passa a raiva, pede desculpas.

Quando ela está nervosa acaba descontando em mim.

Ela é mau-humorada.

\section{Omauhumor delaimpede que eu saia com os amigos.}

O trabalho de minha mãe atrapalha sua atenção para comigo.

Sinto dificuldades em contar meus problemas para ela, pois vive ocupada.

Sinto que ela não me dá atenção.

Ela ignora o que eu gosto.

Ela ignorameus problemas.
Quando o adolescente desrespeita ou não cumpre alguma regra o terapeuta age de forma consistente com o que foi combinado anteriormente, ou seja, as conseqüências do comportamento inadequado são contingentes ao comportamento e não ao humor do terapeuta.

Quando o adolescente desrespeita ou não cumpre alguma regra o terapeuta age de forma consistente com o que foi combinado anteriormente, ou seja, as conseqüências do comportamento inadequado são contingentes ao comportamento e não ao humor do terapeuta.

Quando o adolescente desrespeita ou não cumpre alguma regra o terapeuta age de forma consistente com o que foi combinado anteriormente, ou seja, as conseqüências do comportamento inadequado são contingentes ao comportamento e não ao humor do terapeuta.

As conseqüências do comportamento são contingentes ao comportamento e não ao humor do terapeuta.

As conseqüências do comportamento são contingentes ao comportamento e não ao humor do terapeuta.

O humor do terapeuta não deve interferir na tomada das decisões acerca dos procedimentos adotados nas intervenções.

A terapeuta dá atenção ao adolescente durante as sessões e fora delas desde que seja solicitada de forma adequada.

A terapeuta dá atenção ao adolescente durante as sessões e fora delas desde que seja solicitada de forma adequada.

A terapeuta dá atenção ao adolescente durante as sessões e fora delas desde que seja solicitada de forma adequada.

A terapeuta pergunta do que o adolescente gosta e procura falar e mostrar para ele que sabe de suas preferências, valorizando-as quandopossível.

A terapeuta reforça o comportamento do adolescente de contar seus problemas e quando possível orienta quantoà resoluçãodos mesmos. 
Ela ameaça que vai me bater ou castigar e A terapeuta não faz uso de ameaças; depois nada acontece. esclarece as regras e cumpre-as.

Quando ela me castiga, peço para sair do A terapeuta age de maneira consistente com castigo, e após um pouco de insistência, ela as regras.

deixa.

Durante uma briga eu xingo ou grito com ela e, então, ela me deixa em paz.

Quando ela me manda estudar, arrumar o quarto ou voltar para casa, e não obedeço, ela "deixa pra lá".

Ela avisa que não vai me dar um presente caso não estude, mas, na hora " $\mathrm{H}$ ", ela fica com pena e dá o presente.

Quando fico muito nervoso (a) em uma discussão ou briga, percebo que isto amedronta minha mãe.

A terapeuta interrompe o atendimento ou atividade, de forma firme e tranqüila, quando o adolescente briga ou xinga e descreve para o adolescente as contingências de acordo com as quais está se comportando.

A terapeuta faz observações contingentes a comportamentos clinicamente relevantes do adolescente no momento em que estes ocorrem.

A terapeuta verifica a realização de tarefas e o cumprimento de combinados feitos com o adolescente em psicoterapia.

A terapeuta age de maneira consistente com as regras.

A terapeuta interrompe o atendimento ou atividade, de forma firme e tranqüila, quando o adolescente briga ou xinga e descreve para o adolescente as contingências de acordo com as quais está se comportando.

A terapeuta faz observações contingentes a comportamentos clinicamente relevantes do adolescente no momento em que estes ocorrem. 
Ela critica qualquer coisa que eu faça, como o quarto estar desarrumado ou estar com os cabelos despenteados.

Quando saio, ela telefona atrás de mim muitas vezes.

Ela controla com quem falo ou saio.

Especialmente nas horas das refeições, ela fica dando as "broncas".

Se vou a uma festa ela somente quer saber se bebi, se fumei ou se estava com aquele grupo de maus - elementos.

Quando estou aborrecido (a) ela fica insistindo para eu contar o que aconteceu, mesmo que eu não queira contar.

Ela me bate com cinta ou outros objetos.

Tenho muito medo de apanhar dela.
A terapeuta enfatiza aspectos positivos do comportamento do adolescente e quando isto não é possível, a terapeuta faz a análise funcional da situação com o adolescente objetivando a aquisição de novos repertórios e a resolução de problemas.

A terapeuta reforça o comportamento do adolescente de fornecer informações sobre sua rotina espontaneamente.

Pergunta como foi a semana do adolescente e ouve atentamente.

A terapeuta enfatiza aspectos positivos do comportamento do adolescente e quando isto não é possível, a terapeuta faz a análise funcional da situação com o adolescente objetivando a aquisição de novos repertórios e a resolução de problemas.

A terapeuta faz observações contingentes a comportamentos clinicamente relevantes do adolescente no momento em que estes ocorrem.

Pergunta como foi a semana do adolescente e ouve atentamente.

A terapeuta enfatiza aspectos positivos do comportamento do adolescente e quando isto não é possível, a terapeuta faz a análise funcional da situação com o adolescente objetivando a aquisição de novos repertórios e a resolução de problemas.

Demonstra interesse em ajudar a resolver problemas quando o adolescente está triste ou aborrecido.

A terapeuta em hipótese alguma faz uso de punição física. 


$$
\begin{aligned}
& \text { m } \\
& \text { 요 } \\
& \text { ฟे } \\
& \stackrel{\sim}{\sim} \\
& \text { స } \\
& \text { i } \\
& \approx
\end{aligned}
$$

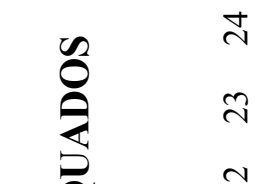

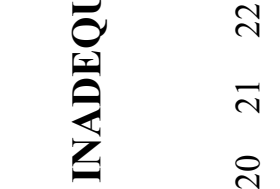

$$
\begin{aligned}
& \text { ช } \\
& \text { 长究 } \\
& \text { ñ } \\
& \text { 选哭 }
\end{aligned}
$$

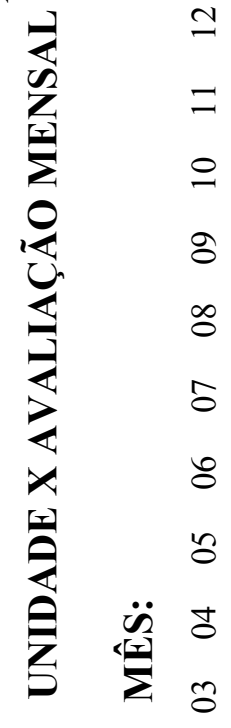

$$
\begin{aligned}
& \text { ชิ } \\
& \overline{0}
\end{aligned}
$$

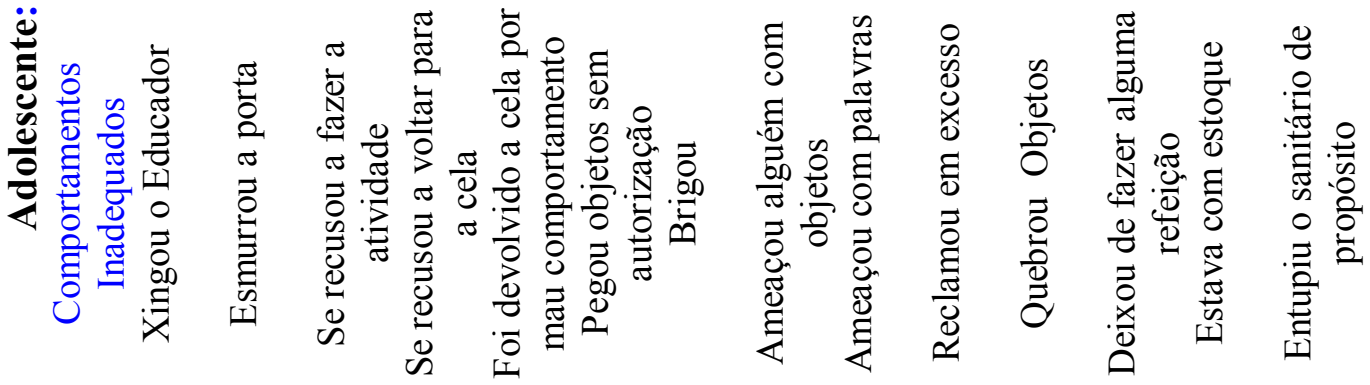




\section{ANEXO 6 \\ Instrumento para avaliação de comportamentos do terapeuta: sistema de categorias de registro das verbalizações do terapeuta adaptado do Sistema Multidimensional de categorização de comportamentos da relação terapêutica de Zamignani (2007) - ADAPTADO PARA O PRESENTE ESTUDO}

Esse sistema de categorias faz parte da tese de doutorado do primeiro autor "O desenvolvimento de um sistema multidimensional para a categorização e análise de comportamentos na interação terapeuta-cliente", ainda em fase de elaboração. É vedada sua reprodução total ou parcial e também o seu uso para qualquer fim sem a autorização expressa dos autores.

1.0. Critérios para categorização a partir do software The Observer:

Alguns critérios foram definidos de forma a normatizar o processo de categorização das sessões e assim evitar diferenças entre observadores devidas a escolhas divergentes relativas a esse processo.

\subsection{Unidade para categorização:}

1.3.1. Categorias de registro: A unidade de análise para a seleção de uma categoria de registro é um segmento de verbalização classificável em uma determinada categoria de registro. Uma mesma verbalização pode, portanto, conter mais de uma categoria e, para sua categorização, ela deve ser dividida em diferentes segmentos. Um segmento, por sua vez, pode ter mais de uma frase gramatical. Quando, dentro de uma mesma verbalização, ocorrer a mudança de categoria, o início desse novo evento deve ser marcado ao início da frase gramatical na qual ocorreu a mudança. O mesmo vale para a finalização de uma categoria, que deverá ser marcada ao final da frase. Nunca uma mesma frase é fragmentada em mais der uma categoria.

O momento de início da categorização no software The Observer deve coincidir imediatamente com o início da frase que dá início ao segmento selecionado, o mesmo vale para o final do período, que deve coincidir imediatamente com o final da frase. Deve ser tomado muito cuidado com relação a esse critério, pois para o cálculo de concordância entre diferentes observadores é permitido o máximo de 1.59 segundos de diferença entre categorizadores, caso contrário, considera-se que ocorreu discordância na categorização.

1.3.1.1. Quanto à inserção da categoria "silêncio". Esta categoria deve ser inserida apenas quando há uma pausa de mais de dois segundos em uma verbalização. Pequenas interrupções de menos de dois segundos ao longo de uma mesma verbalização (tais como pausas para formulação da frase ou respiração não deverão ser categorizadas como episódios de "silêncio".

\subsubsection{Qualificadores:}

1.3.2.2. Tom emocional: A categorização do qualificador TOM EMOCIONAL deve detectar unidades menores da interação. Portanto, estes qualificadores deverão ser categorizados pela sua presença ou não em determinada FRASE, quer ele ocorra em qualquer momento desta frase, mesmo que, durante a maioria dela, ele não esteja presente (por exemplo, uma simples ocorrência de sorriso fechado ou choro leve em qualquer ponto de uma frase implicará em sua categorização "+1" ou "-1" respectivamente como qualificadores "tom emocional"). Este critério pressupõe que, em um mesmo segmento, podem ocorrer diferentes tons emocionais (por exemplo, durante a ocorrência de um mesmo episódio de RELATO do cliente, o qualificador TOM EMOCIONAL pode variar entre diferentes tons, a depender das mudanças na propriedades da fala, desde que tal mudança seja delimitada pelo início e fim das frases nas quais cada mudança ocorreu").

Glossário:

Verbalização: Fala do participante compreendida entre a fala imediatamente precedente e a próxima fala do outro participante na interação ou, caso haja um período de silêncio de mais de dois segundos entre as verbalizações de diferentes participantes ou entre verbalizações do mesmo participante, o início ou final da verbalização será considerado após o silêncio anterior ou antes do silêncio posterior (exemplo: em uma interação na qual há (a) uma fala do terapeuta, seguida por (b) silêncio de mais de dois segundos, e depois disso, (c) uma fala do cliente, seguida imediatamente por (d) uma nova fala do terapeuta, será considerada uma verbalização do cliente tudo o que ele disser entre a b e d).

Segmento de Verbalização: É um trecho de verbalização de um participante, classificável em uma determinada categoria de registro. Uma mesma verbalização pode, portanto, conter mais de um segmento, e cada um dos segmentos que a compõem, serem classificados por meio de diferentes categorias. Um segmento, por sua vez, pode conter várias frases completas.

Frase: 
Categorias do Terapeuta

Terapeuta Solicita Relato - SRE (Solicitação de Relato)

Terapeuta facilita o relato do cliente - FAC (Facilitação)

Terapeuta demonstra empatia - EMP (Empatia)

Terapeuta Fornece Informações - INF (Informação) .....

Terapeuta Solicita Reflexão - SRF (Solicitação de Reflexão)

Terapeuta recomenda ou solicita a execução de ações, tarefas ou técnicas - REC (Recomendação)

Terapeuta interpreta - INT (Interpretação) ....

Terapeuta aprova ou concorda com ações ou avaliação do cliente - APR (Aprovação)

Terapeuta reprova ações ou avaliações do cliente - REP (Reprovação)

Outras verbalizações do Terapeuta - TOU (Outras Terapeuta).

Registro Insuficiente - TIN (Insuficiente Terapeuta)

\section{Terapeuta Solicita Relato - SRE (Solicitação de Relato)}

\section{Definição:}

Verbalizações nas quais o terapeuta solicita ao cliente descrições de eventos, sentimentos ou pensamentos ou ainda solicita ao cliente o registro de informações.

Tipo de evento sobre os quais o relato/registro do cliente pode ser solicitado: podem incluir ações do cliente e/ou de terceiros, sentimentos, pensamentos ou tendências à ação do cliente, aspectos da história de vida do cliente, eventos ambientais relacionados ou não ao comportamento do cliente.

Origem do evento na sessão: Os eventos sobre os quais o relato do cliente é solicitado podem ter sido relatados pelo cliente ou observados pelo terapeuta.

Tempo no qual o evento em questão foi observado/relatado: A solicitação de relato do terapeuta pode se referir a (a) eventos ocorridos/ relatados imediatamente antes, (b) eventos ocorridos/ relatados em outros momentos da mesma sessão (c) eventos ocorridos/ relatados em um passado recente ou remoto ou (d) eventos ocorridos/ relatados em sessões anteriores.

Estão inclusas nessa categoria:

(1) solicitação de informações sobre eventos: terapeuta solicita ao cliente que descreva fatos ocorridos, informações específicas, detalhes, ou esclarecimentos a respeito de eventos.

$>\mathrm{T}^{21}:$ Me conta... por que é que você está procurando terapia? [SRE]

$>\mathrm{T}$ : E quando é que isso começou? [SRE]

T: Você consegue lembrar de um exemplo específico no qual isso aconteceu? [SRE]

(2) solicitação de relatos de sentimentos ou relato de eventos relacionados a sentimentos: terapeuta solicita ao cliente que relate seu sentimento com relação a eventos.

$>\mathrm{T}$ : Como você se sentiu quando ele te falou isso? [SRE]

$>\mathrm{T}$ : Você se lembra de alguma situação na qual você se sentiu da mesma forma? [SRE]

$>\mathrm{T}$ : Em que momentos você tem se sentido assim? [SRE]

(3) solicitação de observação: solicitação do terapeuta para que o cliente observe e/ou registre a ocorrência de eventos, como parte de uma técnica terapêutica ou como estratégia para coleta de dados.

T: Eu gostaria que você registrasse as situações que te provocam ansiedade, para que possamos discutir na semana que vem. [SRE]

$>\mathrm{T}$ : Vamos fazer uma coisa... eu quero que você anote em um caderninho o que você comeu em cada refeição, a que horas você comeu, e se aconteceu algo relevante naquele dia ou logo antes de

${ }^{21} \mathrm{C}$ indica uma fala de cliente, $\mathrm{T}$ uma fala do terapeuta. Um novo diálogo é iniciado em cada marcador 
você comer. [SRE] Vamos ver se com isso a gente entende melhor em que momentos você tem maior dificuldade em controlar a comida. [INF]

$>$ T: Então... Eu quero que você anote pra mim as situações dentro da sua casa, nas quais você faz o ritual. Então, escreve assim " quando eu entro no quarto... eu penso em tal coisa e preciso fazer tal coisa...". Então você pode até anotar só as situações que te deixam ansiosa, tipo, no quarto, a torneirinha do gás que está lá fora... algumas das coisas fixas da sua casa, que ao ver, ou simplesmente saber que estão lá, você inicia o ritual. [SRE]

\section{Forma:}

Solicitações de relato apresentam tipicamente a forma interrogativa, constituindo-se em:

(A) perguntas fechadas - que solicitam respostas curtas, confirmações ou respostas do tipo "sim" ou "não".

Ex: $>\mathrm{T}$ : Ontem você foi à aula de capoeira? [SRE]

T: E você se sente bem com isso? [SRE]

T: Você tem se sentido assim todo o tempo ou só em algumas situações? [SRE]

(B) perguntas abertas - que solicitam que o cliente descreva, relate ou discorra sobre determinado assunto.

Ex: $>$ T: Sobre o que você gostaria de falar hoje? [SRE]

T: Você teria algum um exemplo de uma situação na qual você não conseguiu responder ao seu chefe? [SRE]

T: Como você se sente quando seu irmão faz essas coisas? [SRE]

T: Teve uma vez que você falou comigo que nunca tinha feito terapia com homem. Que, era uma experiência nova. Que era legal de experimentar, de ver como é que era... Agora que a gente já ta trabalhando junto há um tempinho, como você está se sentindo? [SRE]

(C) Podem também apresentar a forma imperativa, solicitando que o cliente descreva ou relate eventos.

$>\mathrm{T}$ : Fale-me um pouco mais sobre isso. [SRE]

T: Me conte o que aconteceu mais recentemente. [SRE]

T: Estive pensando sobre o que conversamos na semana passada e gostaria que você me falasse um pouco mais sobre aquele assunto. [SRE]

T: Agora eu preciso que você me fale um pouco sobre a convivência com sua família. [SRE]

T: Me diz o que você sente quando isso ocorre. [SRE]

(D) afirmações ou comentários de clarificação, que sugerem a continuidade da descrição do cliente.

$>\mathrm{T}$ : Eu ainda não entendi. [SRE]

T: Você me disse o que você pensa. Eu ainda não sei como você se sente com relação a isso. [SRE]

\section{Contexto:}

Precedente: Pode ser precedido por qualquer categoria de verbalizações do terapeuta ou cliente ou por períodos de silêncio.

Subseqüente: Tipicamente, esta categoria é seguida por relatos do cliente, confirmações, respostas curtas do tipo "sim", "não" ou verbalizações mínimas do tipo "hum hum", "sei".

\section{Critérios de inclusão ou exclusão:}

(a) Afirmações ou comentários serão considerados SOLICITAÇÃO DE RELATO apenas se não puderem ser classificados em nenhuma outra categoria, com exceção de OUTRAS. SOLICITAÇÃO DE RELATO tem precedência sobre OUTRAS.

(b) Se uma pergunta for feita como parte de uma explicação ou como pedido de confirmação de INTERPRETAÇÃO dada pelo terapeuta, não será considerada SOLICITAÇÃO DE RELATO e registrarse-á unicamente a ocorrências da categoria INTERPRETAÇÃO. 
(C) Quando uma SOLICITAÇÃO DE RELATO do tipo solicitação de observação é acompanhada de explicações do porquê o cliente deve fazer aquela observação, registrar a ocorrência de ambas as categorias - SOLICITAÇÃO DE RELATO e INFORMAÇÃO, cada uma no segmento apropriado da interação.

Ex: $>\mathrm{T}$ : Eu vou sugerir uma coisa. Que você faça um tipo de anotação pra mim, durante essa semana. Eu vou te dar certinho o que que você precisa anotar e você vai fazer toda vez que aparecer esse tipo de pensamento, esse tipo de coisa. [SRE] Porque talvez se você me escrever na hora o que que aconteceu, o que que... talvez eu tenha idéia de quantas vezes isso ocorreu pela semana. Vou ter idéia do tempo que você demorou pra fazer cada ritual, vou ter idéia do que está acontecendo. Com isso, a gente tem uma base boa pra estar trabalhando, se você fizer isso. Durante uma semana, a gente tem uma medida legal de como é que isso ocorre durante o dia ao longo de uma semana. [INF]

\section{Terapeuta facilita o relato do cliente - FAC (Facilitação)}

\section{Definição:}

Esta categoria é utilizada quando o terapeuta emite vocalizações que indicam que ele está atento ao relato do cliente e sugerem a sua continuidade. É constituída tipicamente por verbalizações mínimas:

(1) Verbalizações mínimas: Expressões vocais curtas que sugerem que ele está prestando atenção e que a outra pessoa deveria continuar falando.

\section{Forma:}

(A) Expressões paralinguísticas (do tipo "Hum hum”, “Ahã”), ou afirmações curtas (tais como "Sei”, "certo", "sim").

\section{Contexto:}

Precedente:.

Verbalizações de FACILITAÇÃO costumam ocorrer simultaneamente a verbalizações de RELATO do cliente ou imediatamente após estas, entre pequenas pausas (menores que três segundos).

\section{Subseqüente:}

Verbalizações de FACILITAÇÃO sugerem a continuidade do relato e, portanto, são tipicamente seguidas por RELATO do cliente.

\section{Critérios de inclusão ou exclusão:}

(a) Verbalizações curtas do terapeuta, tais como "certo", "sim", "isso", que ocorrerem durante a fala do cliente devem ser categorizadas como FACILITAÇÃO, e não APROVAÇÃO.

(b) FACILITAÇÃO só é categorizada se acontecer enquanto o cliente tiver a palavra. Não é codificado quando ocorrer durante pausas de três segundos ou mais na conversação. Verbalizações curtas do terapeuta, tais como "certo", "sim", “isso", ou "hum hum" que ocorrerem após solicitação de confirmação do cliente ou imediatamente após o cliente terminar uma fala serão categorizadas como APROVAÇÃO (quando após o relato de ações do cliente) ou EMPATIA (quando após a descrição de outros eventos).

(c) Nunca devem ocorrer duas falas seguidas categorizadas como FACILITAÇÃO. FACILITAÇÃO nunca é categorizada em dobro.

(d) A verbalização "certo", quando dita sarcasticamente, sugerindo discordância, deve ser categorizada como REPROVAÇÃO.

(e) APROVAÇÃO precede FACILITAÇÃO. Quando em dúvida entre aprovação e Facilitação, categorize APROVAÇÃO.

(f) EMPATIA precede FACILITAÇÃO. Quando em dúvida entre EMPATIA e FACILITAÇÃO, categorize EMPATIA.

(g) Verbalizações curtas ou expressões paralinguísticas, quando emitidas pelo terapeuta após um pedido de confirmação do cliente sobre seu entendimento do que ele está dizendo, serão categorizadas como INFORMAÇÃO. 


\section{Terapeuta demonstra empatia - EMP (Empatia)}

\section{Definição:}

Esta categoria é composta pelas seguintes ações do terapeuta, que sugerem expressão de afeto, compreensão e aceitação do cliente:

(1) Verbalizações nas quais o terapeuta demonstra compreender os estados internos e/ou a condição à qual o cliente está exposto, validando seus atos ou sentimentos, sem julgamento, avaliação ou crítica ${ }^{22}$.

(1a) nomeação de sentimentos: Terapeuta nomeia ou infere sentimentos, valores e/ou a importância de eventos experimentados pelo cliente a partir de seu comportamento não vocal, do contexto ou a partir de sua descrição de eventos.

$$
\begin{aligned}
\text { Ex: } & >\mathrm{T} \text { : Imagino que isso te deixa ansioso. [EMP] } \\
& >\mathrm{T} \text { : Isso que você descreve parece mais raiva que tristeza. [EMP] } \\
& >\mathrm{T} \text { : Você me parece muito irritado. [EMP] }
\end{aligned}
$$

(1b) exclamações empáticas: Comentários em forma de exclamação, apresentados após a descrição de eventos que não ações do cliente, consistentes com o assunto relatado e que indicam interesse nele.

$$
\begin{aligned}
\text { Ex: } & >\mathrm{T}: \text { é mesmo? [EMP] } \\
& >\mathrm{T} \text { : que coisa! [EMP] } \\
& >\mathrm{T} \text { : nossa! [EMP] }
\end{aligned}
$$

(1c) verbalizações de cuidado: verbalizações nas quais o terapeuta demonstra preocupação pessoal com o cliente, quando não acompanhada de crítica ou explicação.

Ex: $>\mathrm{T}$ : Como é que você está? Na semana passada você estava super resfriada. [EMP]

(1d) auto-revelações empáticas: verbalizações nas quais o terapeuta relata sua experiência em situações semelhantes àquela relatada pelo cliente, quando tal relato não sugerir a solução de algum problema em discussão ou da queixa sendo analisada.

Ex: $>\mathrm{T}$ : Você sabe... eu também já passei por isso... é muito chato quando a gente investe toda a energia em um negócio e ele não dá certo... posso imaginar o quanto você está frustrada... [EMP]

(1e) validação de discordâncias ou críticas do cliente: Verbalizações do terapeuta nas quais ele revê suas próprias ações durante o processo terapêutico, corrigindo sua intervenção, admitindo seus erros ou pedindo desculpas por alguma ação sua com relação ao cliente.

Ex: $>$ C: Estou frustrado. Eu fiz tudo o que você me pediu e você não foi capaz de me ajudar pra que meu filho largasse as drogas. [REL]

T: Eu gostaria muito de tê-lo ajudado para mudar essa situação. Eu me pergunto o que poderia ter sido diferente, mas o fato é que não foi possível e eu também me sinto frustrado por isso. [EMP]

(2) humor: Verbalizações que produzem humor ou extraem o lado cômico ou engraçado de determinada situação. Inclui verbalizações acompanhadas por risadas, que tenham sido humorísticas, mesmo que remotamente.

Ex: > C: É, mas eu não dei [o beijo que o namorado havia pedido], claro, falei "magina, tô dirigindo, olha o trânsito!",[REL] nessas alturas o trânsito ridículo, na Castelo, né? Mas eu nem senti passar... [REL]

T: Quanto mais trânsito melhor, que cê fica mais tempo com ele. (risos) [EMP]

(3) apoio: Verbalizações nas quais o terapeuta afirma sua disponibilidade para ajudar o cliente a superar determinada situação.

\footnotetext{
${ }^{22}$ Adaptado de Falcone (2000)
} 
Ex: $>$ T: Eu não sei qual será a sua decisão nesse caso, mas qualquer que ela seja, eu tô do seu lado. [EMP]

$>\mathrm{T}$ : Conte comigo. [EMP]

(4) comentários de entendimento: Comentários breves apresentados após uma descrição, que resumem em poucas palavras o essencial do que o cliente disse, ou inferem a continuidade da descrição, sugerindo interesse no assunto e demonstrando que está atento ao relato.

Ex: $>$ C: ...deixei bem agradável, a cozinha com toalha bonita, e a sala, tal, e no Sábado falei pra caseira: "cê lava a varanda, coloca essa toalha na mesa da varanda, nesse tripé de ferro fundido coloca um vasinho". Ela até nem colocou o meu, ela foi pegar um dela, de onze horas amarelas, assim. [REL]

T: Todo mundo ajudando. [EMP]

$>$ C: Daí, ficamos até de noite, fiquei lá, falei, vou dar uma ligada [REL]

T: E ele no plano de sedução... [EMP]

$>\mathrm{T}$ : Vejo que essa tem sido uma parte crucial da sua vida. [EMP]

(5) Paráfrases: Verbalizações nas quais o terapeuta apresenta de forma resumida o que foi dito em algum ponto anterior pelo cliente na mesma sessão, por meio de repetição literal ou reorganização das verbalizações do cliente, desde que essa reorganização não implique em uma INTERPRETAÇÃO diferente daquela descrita no relato do cliente ou não acrescente informações ou opiniões do terapeuta que não estavam na fala do cliente. A reformulação pode também ser uma paráfrase de qualquer verbalização imediatamente precedente, apenas quando ela não contiver descrição de sentimentos do cliente.

Ex: $>$ T: Então você perdeu seu emprego e está muito difícil encontrar um outro. (sintetizando descrição do cliente). [EMP]

\section{Forma:}

(A) EMPATIA pode apresentar a forma de verbalizações breves que resumem, comentam ou recuperam assunto em discussão.

(B) Verbalizações nas quais o terapeuta reformula, sintetiza ou parafraseia a fala do cliente tipicamente tem a forma afirmativa, e contém menos, mas semelhantes palavras que aquelas utilizadas pelo cliente e, normalmente são mais concreta e claras que a verbalização do cliente.

\section{Contexto:}

Precedente:

Verbalizações de EMPATIA tipicamente são precedidas por descrições do cliente, sendo comum serem precedidas por descrições de queixa por parte deste.

Subseqüente:

Qualquer verbalização do cliente ou do terapeuta.

\section{Critérios de inclusão ou exclusão:}

(a) Verbalizações que sugerem que aquilo que o cliente sente ou faz é normal ou esperado, quando ocorrerem de forma sarcástica ou invalidando a descrição do cliente, serão categorizadas como REPROVAÇÃO.

(b) verbalizações que afirmam que algum tipo de evento é normal ou esperado, quando não se referirem a ações ou sentimentos do cliente, serão categorizadas como INFORMAÇÃO.

(c) declarações que sugerem humor, mas que tenham um conteúdo abertamente hostil ao cliente, serão categorizadas como REPROVAÇÃO. Quando em dúvida, codifique EMPATIA.

(d) quando uma verbalização na qual o terapeuta demonstra preocupação pessoal com o cliente é acompanhada de crítica ou explicação, codifique apenas a categoria: REPROVAÇÃO ou INFORMAÇÃO.

Ex: $>$ T: não é possível que você continue bebendo essa quantidade. Fico preocupado com as consequências disso [REP]. 
T: o que me preocupa é a função que o álcool está exercendo em sua vida. O uso do álcool em situações sociais é tranqüilo, mas você o está usando para alívio da ansiedade, como se fosse um remédio. E essa função do álcool é perigosa porque favorece a dependência.[INF].

(e) Comentários em forma de exclamação ou risos, apresentados após a descrição de ações do cliente, serão categorizados como APROVAÇÃO.

(f) Comentários em forma de exclamação ou risos, quando apresentados em tom sarcástico, hostil ou irônico, categorizar REPROVAÇÃO. Ao contrário da categoria REPROVAÇÃO, na categoria EMPATIA, o terapeuta ri com o cliente e não do cliente.

(g) Verbalizações de auto-revelação, quando sugerem a solução de um problema ou queixa do cliente, serão categorizadas como RECOMENDAÇÃO.

(h) Relatos do terapeuta de algum evento de sua própria experiência, quando não sugerirem a solução de problema ou queixa ou a compreensão ou entendimento da experiência do cliente, serão categorizadas como OUTRAS.

(i) Quando um resumo mudar o sentido do que foi dito pelo cliente, classificar como INTERPRETAÇÃO.

(j) Em caso de paráfrase que explicita uma crítica ou aponta uma falta ou erro do cliente, codificar como REPROVAÇÃO. Na dúvida, categorize EMPATIA.

\section{Terapeuta Fornece Informações - INF (Informação)}

\section{Definição:}

Verbalizações nas quais o terapeuta relata eventos ou informa o cliente sobre eventos, que não o comportamento do cliente ou de terceiros, estabelecendo ou não relações causais ou explicativas entre eles.

O evento relatado pode consistir em:

(1) Informações factuais: dados ou fatos relacionados a determinado assunto em discussão.

Ex: $>$ C: Eu penso em fazer uma especialização em biologia. [REL]

T: Biologia requer vários cursos adicionais de laboratório. [INF]

$>\mathrm{T}$ : Eu não conheço um médico com esse nome. [INF]

Ex: $>$ C: Você já atendeu casos como esse? [SOL]

T: Sim, muitos. [INF]

(2) Explicações de eventos: descrição de relações explicativas ou causais entre eventos - relações do tipo "se... então", apenas quando não contém uma análise, descrição ou síntese do comportamento do cliente ou de terceiros.

Ex: $>\mathrm{T}$ : Eu acredito que você tenha tido uma crise de ansiedade isolada, um ataque de pânico. [INT]. Um ataque de pânico pode ocorrer independentemente de a pessoa ter síndrome do pânico. Por exemplo, quando a gente entra em contato com alguma coisa da qual a gente tem muito medo, isso pode provocar um ataque de pânico. [INF] * no segundo trecho da verbalização, embora diga respeito à queixa do cliente, a explicação dada pelo terapeuta não se refere a um comportamento em particular ou a algum padrão comportamental do cliente identificado, e sim a informações sobre fatos advindos da literatura da área, que complementam o diagnóstico apresentado anteriormente.

(3) Explicações de contigüidade entre eventos: Descrição na qual o terapeuta explica a ocorrência de eventos em termos de relações de contigüidade - relações temporais entre eventos - relações do tipo "o evento $\mathrm{X}$ ocorre quando Y ocorre...", apenas quando não dizem respeito ao comportamento do cliente ou de terceiros;

Ex: $>\mathrm{T}$ : É muito comum que a gente tenha um pouco de dor de cabeça ou enjôo logo que começa a tomar o medicamento antidepressivo. Mas depois de uns quinze dias tudo volta ao normal. [INF]

(4) descrição de padrões recorrentes de eventos: terapeuta explica a ocorrência de eventos em termos de padrões recorrentes apenas quando não dizem respeito ao comportamento do cliente ou de terceiros;

Ex: $>$ T: Pessoas que têm problemas com álcool, geralmente têm uma má qualidade de sono. [INF] 
(5) Explicações teóricas e experimentais de eventos: descrição de proposições teóricas ou achados experimentais relativos ao assunto em discussão.

Ex: > T: Não há a necessidade biológica de se dormir por oito horas. A quantidade de sono necessária para cada um é também aprendida. [INF]

Ex: $>\mathrm{T}$ : O desempenho em testes tende a ser melhor depois de uma noite bem dormida. [INF]

(6) Qualificação de eventos: Opiniões, avaliação ou julgamento a respeito de eventos, apenas quando essa não diz respeito a uma ação emitida pelo do cliente, ao cliente propriamente ou à sessão em curso;

Ex: $>$ C: Eu fiquei realmente chocado com aquela cena. [REL]

$>\mathrm{T}$ : Eu acho que a televisão não deveria mostrar esse tipo de coisa. Não acrescenta em nada a vida das pessoas. [INF]

$>$ Não-exemplo: T: Eu penso que você poderia, sim, ter comprado o livro. Afinal, o dinheiro é seu, não é? [REC] * não é uma INFORMAÇÃO do tipo qualificação de eventos, porque implica em uma forma de conselho: compre o livro, além de se referir ao comportamento do cliente.

(7) Justificativas de intervenções: intervenções que explicam, justificam ou desculpam as intervenções do terapeuta.

Ex: $>$ T: eu não gosto desse tipo de procedimento, mas é o único que vai te ajudar nesse momento [INF].

(8) Descrição do programa terapêutico: descrições ou regras sobre o funcionamento de determinadas técnicas, estratégias, jogos, exercícios ou programas terapêuticos ou sobre o andamento da própria sessão;

Ex: $>$ T: Durante a exposição nós vamos trazer para a sessão algo que você teme e você deverá permanecer em contato com ele sem que você faça o ritual. [INF]

$>\mathrm{T}$ : O exercício de relaxamento que eu vou te ensinar agora serve para você controlar a sua ansiedade nas situações mais difíceis... você deve respirar em quatro tempos, contando até quatro bem devagar em cada um deles... inspira em quatro... segura quatro... solta em quatro... e segura quatro... mas precisa ser treinado com freqüência para que você possa ter um melhor domínio sobre sua ansiedade. Se você deixar pra treinar na hora da crise de ansiedade não vai funcionar. [INF]

(9) contrato terapêutico: descrições do terapeuta sobre o funcionamento da terapia (contrato, regras, objetivos), acerto de horários e local para a realização da sessão, para o estabelecimento do contrato terapêutico (enquadre).

Ex: $>\mathrm{T}$ : Nós nos encontraremos duas vezes por semana. [INF]

T: vamos falar sobre a última semana primeiro, então nós vamos falar um pouco mais sobre sua situação em casa e vamos terminar com um exercício de relaxamento. [INF]

$>$ T: o valor da sessão é $\$$. [INF]

$>$ T: Não tem nada sistematizado, do tipo "eu vou ter que ir por aqui, depois por aqui, depois ali, tá?" Então, fica à vontade. A gente vai indo. Não se preocupe com essa coisa da, dessa resistência, desse receio. É natural. Então relaxa. Com o andamento das sessões você vai se sentindo mais à vontade [INF]

\section{Forma:}

INFORMAÇÃO apresenta tipicamente a forma afirmativa descritiva.

\section{Contexto:}

Precedente: Pode ser antecedido ou não por SOLICITAÇÃO do cliente.

Subseqüente: É comum que uma INFORMAÇÃO seja seguida por RECOMENDAÇÃO por parte do terapeuta ou por SOLICITAÇÃO por parte do cliente. Pode também ser seguida por qualquer verbalização do cliente ou do terapeuta.

\section{Critérios de inclusão ou exclusão:}


(a) Quando o terapeuta retomar assuntos ou diálogos discutidos anteriormente estabelecendo alguma relação explicativa sobre o comportamento do cliente ou de terceiros, não será registrada a categoria INFORMAÇÃO, e sim INTERPRETAÇÃO.

(b) Quando o terapeuta fornecer descrições de relações explicativas ou causais entre eventos - relações do tipo "se... então", a respeito do comportamento do cliente ou de terceiros, será categorizado INTERPRETAÇÃO.

(c) Quando uma opinião, avaliação ou julgamento for emitido a respeito de uma ação do cliente, do próprio cliente ou da sessão em curso, ela deve ser categorizada como APROVAÇÃO, REPROVAÇÃO OU EMPATIA, aquela que for mais apropriada.

(d) Verbalizações curtas ou expressões paralinguísticas, quando emitidas pelo terapeuta após um pedido de confirmação do cliente sobre seu entendimento do que ele está dizendo, serão categorizadas como INFORMAÇÃO.

(e) Verbalizações do terapeuta durante um exercício ou atividade, tal como role-playing ou viagem de fantasia serão categorizadas de acordo com suas categorias correspondentes, sendo categorizado INFORMAÇÃO as instruções do terapeuta e RECOMENDAÇÃO a solicitação para o cliente se engajar no exercício.

\section{Terapeuta Solicita Reflexão - SRF (Solicitação de Reflexão)}

\section{Definição:}

Verbalizações nas quais o terapeuta solicita ao cliente qualificações, explicações, interpretações, reflexões ou previsões a respeito de qualquer tipo de evento.

Tipo de evento sobre os quais a reflexão do cliente pode ser solicitada: podem incluir ações do cliente e/ou de terceiros, sentimentos, pensamentos ou tendências à ação do cliente, aspectos da história de vida do cliente, eventos ambientais relacionados ou não ao comportamento do cliente.

Origem do evento na sessão: Os eventos sobre os quais a reflexão do cliente é solicitada podem ter sido relatados pelo cliente ou observados pelo terapeuta.

Tempo no qual o evento em questão foi observado/relatado: A solicitação de reflexão do terapeuta pode se referir a (a) eventos ocorridos/ relatados imediatamente antes, (b) eventos ocorridos/ relatados em outros momentos da mesma sessão ou (c) eventos ocorridos/ relatados em sessões anteriores; (d) previsão sobre eventos futuros.

Estão inclusas nessa categoria:

(1) solicitação de reflexão: terapeuta solicita ao cliente que ele pense ou reflita - imediatamente na sessão ou após seu término - a respeito de determinados eventos.

T: Gostaria que você pensasse nessa semana sobre o que conversamos hoje... sobre os benefícios que você obtém quando se queixa dessa maneira com sua família. [SRF]

(2) solicitação de explicação ou interpretação: terapeuta solicita ao cliente que ele estabeleça ou relate relações entre eventos.

$>\mathrm{T}$ : E você tem alguma hipótese de por que isso aconteceu? [SRF].

T: Você já notou que todos os seus namorados agem com você de forma muito semelhante ao seu pai? [INT] Você acha que isso é apenas uma coincidência? [SRF].

(3) solicitação de avaliação: terapeuta solicita ao cliente que relate sua opinião, julgamento ou avaliação a respeito de eventos.

T: O que você achou da reação dele? [SRF].

T: Você acha correta a forma com que ele agiu? [SRF].

(4) solicitação de previsão: Solicitação do terapeuta para que o cliente faça previsões a respeito de seu comportamento ou do comportamento de outros.

T: Tendo em vista os últimos acontecimentos, você pode imaginar como será a próxima tentativa dele? [SRF]. 
T: E agora, o que você acha que vai acontecer? [SRF].

\section{Forma:}

Solicitações de Reflexão apresentam tipicamente a forma interrogativa, constituindo-se em:

(A) perguntas fechadas - que solicitam respostas curtas, confirmações ou respostas do tipo "sim" ou "não".

Ex: $>\mathrm{T}$ : E você se sente bem com isso? [SRF]

T: E para você isso é certo? [SRF]

(B) perguntas abertas - que solicitam que o cliente descreva, relate ou discorra sobre determinado assunto.

Ex: $>$ T: Você tem alguma explicação para tanta cobrança em seu trabalho? [SRF]

T: Há várias semanas você vem relatando problemas com seu chefe. Você vê alguma relação entre todos esses eventos? [SRF]

(C) Podem também apresentar a forma imperativa, solicitando que o cliente descreva ou relate eventos.

Ex: $\gg \mathrm{T}$ : Eu gostaria que você pensasse sobre isso na próxima semana. [SRF]

T: Veja se esses acontecimentos têm alguma relação. [SRF]

(D) afirmações, comentários ou "dicas", que sugerem como continuidade algum tipo de reflexão por parte do cliente.

Ex: $>$ T: Essas coisas não me parecem apenas coincidência. [SRF]

T: Isso me parece bastante importante, você não acha? [SRF]

\section{Contexto:}

Precedente: Tipicamente essa categoria é precedida por RELATO do cliente.

Subseqüente: Tipicamente, esta categoria é seguida por relatos qualificativos do cliente, explicações, confirmações, respostas curtas do tipo "sim", "não" ou verbalizações mínimas do tipo "hum hum", "sei".

\section{Critérios de inclusão ou exclusão:}

(a) Um pedido do terapeuta para que o cliente pense ou reflita sobre um determinado tema será considerado SOLICITAÇÃO DE REFLEXÃO quando tiver como foco evocar respostas de observação e de descrição de eventos, de modo a melhorar ou aprofundar a análise do tema em discussão. Quando tiver como objetivo modificar o desempenho final do cliente em uma atividade ou tarefa ou qualquer outra situação, deverá ser categorizado RECOMENDAÇÃO.

Exemplo: T: Quando você estiver em uma situação semelhante, antes de reagir atacando, pense nas possíveis razões pelas quais a pessoa pode ter feito aquilo que te desagradou. [REC] ${ }^{*}$ Nesse caso, o pedido do terapeuta para que o cliente pense/observe/reflita visa modificar o desempenho final do cliente em determinada condição e, portanto, caracteriza-se como uma recomendação.

\section{Terapeuta recomenda ou solicita a execução de ações, tarefas ou técnicas - REC (Recomendação)}

\section{Definição:}

Essa categoria contempla verbalizações do terapeuta nas quais ele sugere alternativas de ação ao cliente ou solicita o engajamento do cliente em ações ou tarefas, conforme descrito a seguir:

(1) conselhos: Verbalizações do terapeuta que especificam ações ou conjuntos de ações (de caráter aberto - respostas passíveis de serem observadas por outros que não o próprio cliente - ou encoberto - respostas passíveis de serem observadas apenas pelo próprio cliente - pensamentos ou sentimentos) a serem emitidas pelo cliente, dentro ou fora da sessão.

Ex: $>\mathrm{T}$ : Tente conversar com seu pai durante a semana e lhe falar sobre o que você sente nessas situações. [REC]

$>$ T: Faça a prova amanhã, antes que você esqueça a matéria. [REC] 
T: Você deveria cuidar de sua vida e deixar que seu irmão administre as suas próprias coisas. [REC]

$>\mathrm{T}$ : Agora me diga o mesmo que você acabou de dizer, só que sem mexer as pernas. [REC]

Ex: $>$ T: Você não deve se sentir culpado por uma coisa que não foi sua responsabilidade. Lembrese que nem tudo está sob seu controle. [REC]

Ex: > T: Quando você for enfrentar a situação, lembre-se de todas as vezes que você teve sucesso. [REC]

Não-exemplo: $>$ T: Quero que você reflita sobre o que estava ocorrendo todas as vezes que você obteve sucesso no enfrentamento. [SRF] * não se trata de RECOMENDAÇÃO, porque o que é solicitado pelo terapeuta não é o engajamento do cliente em uma resposta encoberta de topografia especificada.

(2) modelo: Também serão consideradas verbalizações de RECOMENDAÇÃO aquelas nas quais o terapeuta declaradamente comporta-se de forma a oferecer modelos de ação para o cliente.

Ex: $>\mathrm{T}$ : Agora tente fazer um pedido para mim da mesma forma com que acabei de falar. [REC]

Ex: $>\mathrm{T}$ : Tente repetir a seqüência do jogo assim como eu fiz. [REC]

Ex: $>\mathrm{T}$ : Eu vou falar como eu acredito que você deveria conversar com o seu chefe. [REC]

Ex: $>\mathrm{T}$ : Observe agora como eu estou fazendo para depois você fazer o mesmo. [REC]

(3) incentivo: Verbalizações nas quais o terapeuta sugere que o cliente pode ou é capaz de mudar determinado comportamento ou de agir em determinado sentido.

Ex: $>\mathrm{T}$ : Tenho certeza que você é capaz de fazer isso. [REC]

$>\mathrm{T}$ : Da forma com que você está fazendo, muito em breve você estará livre disso.[REC]

(4) Estruturação de atividade: solicitações de atividades, técnicas ou exercícios terapêticos a serem executadas com a participação ou não do terapeuta, durante a interação terapêutica no consultório ou extraconsultório.

T: Vamos experimentar praticar isso em uma representação? Dessa vez, tente dizer diretamente o que você sente. [REC]

$>\mathrm{T}$ : Agora vamos fazer um exercício de exposição: experimente pegar na maçaneta dessa porta e ficar por quinze minutos sem lavar as mãos. [REC]

$>\mathrm{T}$ : Esse assunto é bastante importante. Vamos voltar a falar sobre ele na próxima sessão. [REC]

$>$ T: Então fica combinado para essa semana, de você procurar enfrentar algumas daquelas situações que você classificou como de menor ansiedade. Não importa qual delas, nem se você vai ter sucesso ou não. O mais importante é que você tente enfrentar e fique atento ao que você sente e pensa quando você está enfrentando. [REC]

(5) Solicitação de parada: Ordens ou pedidos de parada ou mudança do comportamento do cliente dentro da sessão.

$>\mathrm{T}$ : Por favor, preste atenção enquanto eu estou falando. [REC]

$>\mathrm{T}$ : Eu gostaria que você não colocasse os pés no sofá. [REC]

$>\mathrm{T}$ : Sente-se em sua cadeira enquanto conversamos. Eu não consigo conversar com você andando pela sala. [REC]

\section{Forma:}

(A) Recomendações podem apresentar a forma imperativa, consistindo em instruções, sugestões, conselhos, avisos, comandos ou ordens.

Ex: $\gg$ T: Experimente fazer... faça... Quero que você vá...

(B) Podem ser apresentadas em forma interrogativa, como uma pergunta que sugere uma ação:

Ex: $>\mathrm{T}$ : Você não acha que seria melhor...? E se você fizesse...? Seria possível...?

(C) Podem também apresentar a forma afirmativa. 
Ex: $>$ T: Acredito que você deveria... Penso que a melhor alternativa seria...

(D) Podem apresentar a forma de permissão, proibição ou obrigação.

$\mathrm{Ex}:>\mathrm{C}$ : Eu posso anotar tudo à noite, antes de dormir ou tenho que fazer na hora em que acontece? [SOL]

T: Faça como você achar melhor. O importante é que você registre o máximo de situações que ocorrerem ao longo do dia. [REC]

(E) Confirmações em resposta a perguntas do cliente sobre como proceder, podem ter a forma de verbalizações mínimas ou respostas curtas do tipo sim ou não.

Ex: $>$ C: Então eu tenho que ficar na situação, mesmo com medo? [SOL]

T: Hum Hum [REC]

\section{Contexto:}

Precedente:

Em algumas interações, pode ser observada a ocorrência de seqüências de INFORMAÇÕES e/ou INTERPRETAÇÕES, seguidas por RECOMENDAÇÃO.

RECOMENDAÇÕES podem ser precedidas por verbalizações de RELATO do cliente.

Podem também ser precedidas por SOLICITAÇÃO por parte do cliente.

Subseqüente:

Tipicamente, RECOMENDAÇÕES são seguidas por CONCORDÂNCIA do cliente, OPOSIÇÃO ou períodos de silêncio.

Critérios de inclusão ou exclusão:

(a) Orientações para a emissão de respostas de caráter encoberto só serão consideradas RECOMENDAÇÃ̃O quando a verbalização do terapeuta especificar a resposta a ser emitida pelo cliente. Quando a orientação é no sentido de refletir ou pensar sobre determinada questão, sem que seja especificada a resposta encoberta, ela será categorizada como SOLICITAÇÃO DE REFLEXÃO.

D Exemplo: T: Quando você estiver em uma situação semelhante, antes de reagir atacando, pense nas possíveis razões pelas quais a pessoa pode ter feito aquilo que te desagradou. [REC] * Nesse caso, o pedido do terapeuta para que o cliente pense/observe/reflita visa modificar o desempenho final do cliente em determinada condição e, portanto, caracteriza-se como uma recomendação.

Não-exemplo: $>\mathrm{T}$ : Quero que você reflita sobre o que estava ocorrendo todas as vezes que você obteve sucesso no enfrentamento. [SRF] * não se trata de RECOMENDAÇÃO, porque o que é solicitado pelo terapeuta não é o engajamento do cliente em uma resposta encoberta de topografia especificada.

(b) Confirmações em resposta a perguntas do cliente sobre como proceder serão consideradas RECOMENDAÇÃO.

(c) quando sugestões forem apresentadas de modo sarcástico, categorize REPROVAÇÃO.

(d) qualquer permissão ou proibição do terapeuta a respeito de ações a serem executadas dentro ou fora da sessão será categorizada como RECOMENDAÇÃO.

(e) Quando uma verbalização do tipo "se... então" sugerir que o cliente poderá melhorar caso realize determinadas ações ou tarefas propostas pelo terapeuta, serão categorizadas ambas as categorias: RECOMENDAÇÃO e INFORMAÇÃO, ou RECOMENDAÇÃO e INTERPRETAÇÃO cada uma no respectivo segmento da verbalização, a depender dos critérios estabelecidos para cada categoria.

(f) Verbalizações nas quais o terapeuta revela sua própria experiência com relação a um evento sendo discutido, quando tal relato sugere a solução de algum problema em discussão ou da queixa sendo analisada, supõem a proposição do terapeuta como um modelo e, portanto, serão categorizadas como RECOMENDAÇÃO. Quando o terapeuta revela informações pessoais de forma a sugerir compreensão ou entendimento da experiência do cliente, será categorizado EMPATIA. Relatos do terapeuta de algum evento de sua própria experiência, quando não sugerirem a solução de problema ou queixa ou a compreensão ou entendimento da experiência do cliente, serão categorizadas como OUTRAS. 
(g) Quando o terapeuta oferece um modelo de ação e sugere que o cliente siga o modelo imediatamente na sessão, será categorizado RECOMENDAÇÃO.

(h) Quando uma RECOMENDAÇÃO é acompanhada de explicações do porquê o cliente deve seguir aquela RECOMENDAÇÃO, registrar a ocorrência de ambas as categorias - RECOMENDAÇÃO e INFORMAÇÃO , cada uma no segmento apropriado da interação.

Ex: $>\mathrm{T}$ : Eu vou sugerir uma coisa. Que você faça um tipo de anotação pra mim, durante essa semana. Eu vou te dar certinho o que que você precisa anotar e você vai fazer toda vez que aparecer esse tipo de pensamento, esse tipo de coisa. [REC] Porque talvez se você me escrever na hora o que que aconteceu, o que que... talvez eu tenha idéia de quantas vezes isso ocorreu pela semana. Vou ter idéia do tempo que você demorou pra fazer cada ritual, vou ter idéia do que está acontecendo. Com isso, a gente tem uma base boa pra estar trabalhando, se você fizer isso. Durante uma semana, a gente tem uma medida legal de como é que isso ocorre durante o dia ao longo de uma semana. [INF]

(i) solicitações que requererem uma ação dentro da sessão serão considerados RECOMENDAÇÃO, com exceção de solicitações ou perguntas que solicitam descrição ou confirmação de eventos, que serão categorizados como SOLICITAÇÃO DE RELATO.

(j) Verbalizações do terapeuta que ocorrerem durante uma atividade ou técnica desenvolvidas dentro da sessão terapêutica serão categorizadas de acordo com sua forma e função características, devendo apenas a solicitação para que o cliente se engaje na técnica/exercício ser categorizada como RECOMENDAÇÃO.

(k) Perguntas do terapeuta ou falas em forma imperativa que solicitem que o cliente descreva eventos, mesmo que sobre temas diferentes daquele em curso na sessão, ou que mudem a direção da conversação, não serão considerados RECOMENDAÇÃO, e sim SOLICITAÇÃO DE RELATO.

\section{Terapeuta interpreta - INT (Interpretação)}

\section{Definição:}

Verbalizações nas quais o terapeuta descreve, supõe ou infere relações causais e/ou explicativas (funcionais, correlacionais, ou de contiguidade) a respeito do comportamento do cliente ou de terceiros ou identifica padrões de interação do cliente e/ou de terceiros. (esse critério diferencia essa categoria da categoria INFORMAÇÃO que, por sua vez, compreende explicações a respeito de outros eventos que não o comportamento do cliente e/ou de terceiros).

Tipo de evento sobre os quais as relações são estabelecidas: As relações estabelecidas devem ter como foco o comportamento do cliente ou de terceiros e podem dizer respeito a respostas do cliente e/ou de terceiros, sentimentos, emoções e pensamentos do cliente e/ou de terceiros, aspectos da história de vida do cliente ou de terceiros, eventos ambientais relacionados ao comportamento do cliente ou de terceiros.

Origem do evento na sessão: Os eventos sobre os quais as relações são estabelecidas podem ter sido relatados pelo cliente ou observados pelo terapeuta.

Tempo no qual o evento em questão foi observado/relatado: As relações estabelecidas podem se referir a (a) eventos ocorridos/ relatados imediatamente antes, (b) eventos ocorridos/ relatados em outros momentos da mesma sessão ou (c) eventos ocorridos/ relatados em sessões anteriores (d) especulações sobre eventos futuros.

Essas verbalizações podem incluir:

(1) descrição explicativa de relações entre ações (do cliente e/ou de terceiros) e outros eventos ou ações:

relações explicativas ou causais entre eventos - relações do tipo "se... então", apenas quando dizem

respeito ao comportamento do cliente ou de terceiros;

Ex: $>$ T: Porque quando você faz isso, você fica mais em contato com você. Porque se você começa a negar... ... Você começa a perder contato com aquilo que você sente. Assim: como é que as coisas que acontecem no mundo me afetam? Entendeu? [INT] 
T: Talvez o problema não seja de motivação, mas que até agora as coisas ainda não deram certo. Muito do que a gente faz, pra que a gente se mantenha fazendo depende da conseqüência daquilo que a gente faz. Quando a gente faz uma coisa que tem um a conseqüência imediata, legal. A tendência é que a gente continue fazendo. Quando a conseqüência não é muito legal, a gente tende não fazer mais. (em situação na qual o cliente relata que não está conseguindo dar continuidade em seus projetos, pois não se sente motivado) [INT]

$>\mathrm{T}$ : Você se cobra em melhorar o desempenho sexual com seu marido, mas da maneira como você descreve a relação sexual, ela não é satisfatória para você. Portanto, não existe nada que te motive a continuar procurando. [INT]

(2) descrição de contigüidade entre ações (do cliente e/ou de terceiros) e outros eventos ou ações:

terapeuta explica a ocorrência de eventos em termos de relações de contigüidade - relações temporais

entre eventos - relações do tipo " o evento X ocorre quando $\mathrm{Y}$ ocorre...”, apenas quando dizem respeito ao comportamento do cliente ou de terceiros;

$>\mathrm{T}$ : A impressão que eu tenho é que sempre que ele te faz um elogio, ele é seguido por uma crítica, do tipo... "você foi ótimo na apresentação, mas..." [INT]

(3) descrição de regularidades ou padrões recorrentes de ações (do cliente e/ou de terceiros): terapeuta explica a ocorrência de eventos em termos de padrões recorrentes apenas quando dizem respeito ao comportamento do cliente ou de terceiros ou temas recorrentes na verbalização do cliente;

$>\mathrm{T}$ : Você já notou que, sempre que há alguma situação muito difícil pela frente, você fica doente? [INT]

$>\mathrm{T}$ : Essa é uma dúvida que te persegue, né? Se é por você ou pela gravidez que ele está mudando... [INT]

$>\mathrm{T}$ : Você se dá conta de que suas obsessões sempre são relacionadas a situações nas quais você age por impulso com outras pessoas e depois se arrepende? Aí você fica ruminando sobre o que poderia ter sido diferente... [INT]

(4) diagnóstico: apresentação de diagnóstico ou rótulo relativo a algum padrão de interação ou conjunto de sintomas descritos pelo cliente ou observados pelo terapeuta.

Ex: $>$ Você acha que eu estou deprimido? [SOL]

T: Você parece mais ansioso que deprimido [INT]

T: Isso que você acabou de descrever é conhecido pela psiquiatria como Transtorno ObsessivoCompulsivo. (após a descrição do cliente de sua queixa) [INT]

(5) devolutiva de avaliação padronizada: apresentação de conclusão relativa a algum teste, escala ou instrumento de avaliação psicológica.

Ex: $>\mathrm{T}$ : $\mathrm{O}$ teste indica que você tem maior interesse por profissões relacionadas ao cuidado e atendimento de pessoas. [INT]

(6) estabelecimento de síntese: sínteses ou conclusões formuladas sobre o comportamento do cliente ou de terceiros, a partir de eventos relatados pelo cliente ou observado pelo terapeuta, que apresentem uma INTERPRETAÇÃO diferente daquela descrita no relato do cliente ou acrescentam informações ou opiniões do terapeuta que não estavam na fala do cliente.

Ex: $>$ T: Então, você está dependente de álcool... já deve estar começando a beber de manhã, eu suponho. [INT]

(7) metáforas ou analogias explicativas: descrições por meio de metáforas ou analogias, que contém, de forma implícita ou direta, análises sobre padrões de interação do cliente ou sobre relações entre eventos.

Ex: $>$ T: Quando você falou que tinha dor de cabeça, eu lembrei daquelas mulheres que na hora de transar dizem "ah, eu não posso, estou com dor de cabeça". [INT]

(8) inferências: suposições sobre a ocorrência de relações ou eventos até então não relatados pelo cliente ou não descritos pelo terapeuta, apenas quando essa inferência não diz respeito a sentimentos e emoções do cliente. (esse critério diferencia essa sub-categoria de interpretação da categoria EMPATIA). 
Ex: $>\mathrm{T}$ : Imagino que ele tenha sido extremamente gentil nas primeiras semanas e depois... [INT]

(9) previsões: suposições sobre a ocorrência futuras de comportamentos do cliente ou de terceiros.

Ex: $>\mathrm{T}$ : Acredito que a próxima coisa que ele vai fazer é te convidar para sair... [INT]

(10) confrontação: Verbalizações nas quais o terapeuta aponta discrepâncias ou contradições no discurso do cliente (seja em tom confrontativo ou agradável).

Ex: $>$ T: Você estava dizendo há pouco que seu marido não lhe dá a menor atenção, mas agora você está me dizendo uma série de cuidados que ele tem com você. [INT] O que parece isso? [SRE]

(11) normalização: verbalizações que sugerem que aquilo que o cliente sente ou faz é normal, ou esperado.

Ex: $>\mathrm{T}:$ É normal que você se preocupe com isso. [EMP]

$>\mathrm{T}$ : Com tudo isso que está acontecendo, seria estranho que você ficasse tranqüilo, não é mesmo? [EMP]

\section{Forma:}

(1) Explicações ou Interpretações apresentam tipicamente a forma afirmativa.

(2) Podem, eventualmente, ser apresentadas em forma interrogativa ou ainda...

(3) como uma afirmação seguida de uma pergunta de confirmação.

\section{Contexto:}

Precedente: INTERPRETAÇÕES são tipicamente precedidas por RELATOS do cliente.

Outra situação característica é o uso desse tipo de verbalização ao final da sessão, como forma de encerramento.

Pode, entretanto, ocorrer após qualquer tipo de verbalização do terapeuta ou do cliente.

\section{Subseqüente:}

Interpretações podem ser seguidas por confirmações do cliente, por períodos de silêncio ou ainda por verbalizações de CONCORDÂNCIA ou OPOSIÇÃO por parte deste.

Em algumas interações pode ser observada a ocorrência de seqüências de INTERPRETAÇÃO, seguidas por RECOMENDAÇÃO do terapeuta.

\section{Critérios de inclusão ou exclusão:}

(a) Um segmento de verbalização do terapeuta será categorizado como INTERPRETAÇÃO apenas se a relação apresentada, de alguma forma, acrescenta informações novas ou muda o significado do relato apresentado pelo cliente. Uma mera repetição ou paráfrase do relato do cliente será categorizada como EMPATIA.

(b) A categorização de um trecho como INTERPRETAÇÃO independe da precisão ou correção da análise feita pelo terapeuta, ou de sua concordância por parte do cliente.

(c) Se uma pergunta for feita como parte de uma INTERPRETAÇÃO ou como pedido de confirmação de INTERPRETAÇÃO, registrar-se-á unicamente a ocorrências da categoria INTERPRETAÇÃO.

(d) Quando o terapeuta infere a ocorrência de sentimentos ou emoções do cliente, sua fala será categorizada como EMPATIA.

(e) Quando uma verbalização do tipo "se... então" sugerir que o cliente poderá melhorar caso realize determinadas ações ou tarefas propostas pelo terapeuta, será categorizada RECOMENDAÇÃO.

(f) A previsão de conseqüências negativas ou aversivas para uma ação (ou não ação) do cliente, será considerada REPROVAÇÃO quando sugerir uma ameaça, julgamento ou avaliação do terapeuta (implícito ou explícito) contrários à ação do cliente. Na dúvida, categorize REPROVAÇÃO, que tem precedência sobre INTERPRETAÇÃO.

(g) A mera descrição de conseqüências aversivas a uma ação do cliente por parte do terapeuta, quando não indica ameaça e/ou não sugere um julgamento ou avaliação por parte do terapeuta será categorizada como INTERPRETAÇÃO. Na dúvida, categorize REPROVAÇÃO, que tem precedência sobre INTERPRETAÇÃO. 


\section{Terapeuta aprova ou concorda com ações ou avaliação do cliente - APR (Aprovação)}

\section{Definição:}

Esta categoria é composta pelas seguintes classes de verbalização, todas elas sugerindo aprovação ou concordância a ações do cliente.

(1) avaliação positiva sobre o cliente: Verbalizações nas quais o terapeuta expressa julgamento favorável a ações ou características do cliente (sejam estas relatadas pelo cliente ou observadas pelo terapeuta).

Ex: > T: Você tomou a decisão certa, está lidando com isso muito bem. [APR]

(2) elogios: Verbalizações nas quais o terapeuta diz ao cliente que ele está indo bem ou elogia suas ações, características ou aparência.

Ex: $>$ Você está de parabéns! Sua condução foi perfeita! [APR]

Ex: $>\mathrm{T}$ : Que lindo esse teu colarzinho! [APR]

(3) descrição de ganhos terapêuticos: Verbalizações nas quais o terapeuta descreve os progressos ou sucessos do cliente.

Ex: $\gg$ Puxa, C., eu estava me lembrando da época em que a gente começou a trabalhar juntos. Como as coisas estão mudadas! Você lembra que era difícil pra você até mesmo vir sozinha para cá? E agora você está se virando sozinha, com o maior desprendimento... acho muito legal isso! [APR]

(4) verbalizações de concordância: Verbalizações nas quais o terapeuta confirma ou relata estar de acordo com afirmações verbalizadas pelo cliente.

Ex: $>$ Com certeza! Você tem toda a razão. [APR]

(5) pseudo-discordância: Verbalizações nas quais o terapeuta discorda do cliente, mas o faz de forma a ressaltar características do cliente que ele considera positivas.

Ex: $>\mathrm{C}$ : Eu só melhorei por causa da medicação. [REL]

T: De fato, a medicação pode te ajudar, mas se você não tivesse agido, tudo estaria igual. [APR]

(6) relato de sentimentos positivos: relato de sentimentos que o cliente desperta no terapeuta, que indicam

que gosta dele ou que sente-se bem em sua presença ou que está satisfeito com relação a alguma ação

realizada pelo cliente ou com o andamento da sessão.

Ex: $>$ T: Gostei muito da nossa sessão de hoje. Acho que falamos de assuntos bastante importantes. [APR]

$>\mathrm{T}$ : Você conversa super bem! É muito agradável conversar com você. [APR]

(7) exclamações de aprovação: Verbalizações exclamativas após o relato de alguma ação por parte do cliente, sugerindo que tal ação agradou ao terapeuta.

Ex: $>$ C: Consegui recuperar a minha nota de matemática. [REL]

T: Que máximo!!! [APR]

(8) sorrisos de aprovação: Risos ou comentários em forma de exclamação, apresentados após a descrição de ações do cliente.

Ex: $>$ C: Consegui caminhar todos os dias essa semana. [REL]

T: é mesmo? [APR]

C: Você não sabe! Consegui fechar o negócio com meu apartamento! [REL]

T: não acredito!, [APR]

$>$ C: Daí, fomos para a capela e me chamou a atenção o o cachorro do caseiro, porque desde pequeno ele me acompanha na capela... só que ele não entra. Então ele... põe o pezinho, ele só 
olha para mim ele tira o pé do piso e fica no cimento do lado de fora parado olhando, ele não entra ... é uma coisa bárbara você ver! [REL]

T: nossa, e você ensinou ele... [APR]

(9) agradecimentos: Verbalizações nas quais o terapeuta agradece o cliente por alguma ação deste ou após um elogio.

Ex: $>$ C: Não, você é uma das responsáveis, eu tinha que dizer, não, eu faço questão, eu sou muito franca, sabe, de extrema transparência, é, você, de uma forma assim, muito inteligente, tá sabendo me conduzir assim, entre aspas [CON], porque eu to tendo mais discernimento, sabendo o que é mais conveniente e o que não é e tô tentando encontrar o caminho, não é?, Sem tanto medo de ser feliz. [MEL]

T: Que bom, brigada, fico muito contente. [APR]

\section{Forma:}

Verbalizações de aprovação apresentam tipicamente a forma exclamativa ou afirmativa (do tipo descritiva).

Podem também ser acompanhadas por perguntas de confirmação por parte do terapeuta.

\section{Contexto:}

Precedente:.

Verbalizações de aprovação tipicamente são precedidas por verbalizações de descrição de eventos por parte do cliente.

Também é comum serem precedidas por verbalizações do terapeuta do tipo INFORMAÇÃO ou INTERPRETAÇÃO.

Subseqüente:

Tipicamente são seguidas por CONCORDÂNCIA do cliente, períodos de silêncio ou OPOSIÇÃO, mas podem ser seguidos por qualquer tipo de verbalização.

Critérios de inclusão ou exclusão:

(a) Quando aprovação for acompanhada de descrição do evento que foi alvo da aprovação, registre unicamente a ocorrência da categoria APROVAÇÃO

(b) Quando uma aprovação for acompanhada de explicações de porque aquela ação foi boa ou correta, registrar a ocorrência de ambas as categorias, APROVAÇÃO E INFORMAÇÃO cada uma no seu respectivo segmento.

(c) Verbalizações curtas do terapeuta, tais como "certo", "sim", "isso", ou "hum hum" que ocorrerem durante a fala do cliente serão categorizadas como FACILITAÇÃO, e não aprovação.

(d) Verbalizações curtas do terapeuta, tais como "certo" , "sim", "isso", ou "hum hum" que ocorrerem após solicitação de confirmação do cliente ou imediatamente após o cliente terminar uma fala serão categorizadas como APROVAÇÃO. Na dúvida, categorize FACILITAÇÃO.

(e) Na dúvida entre APROVAÇÃO e FACILITAÇÃO, categorize a primeira. APROVAÇÃO precede FACILITAÇÃO.

(f) Verbalizações exclamativas após o relato de alguma ação por parte do cliente, quando apresentadas em tom sarcástico ou hostil, categorizar como REPROVAÇÃ̃.

\section{Terapeuta reprova ações ou avaliações do cliente - REP (Reprovação)}

\section{Definição:}

Verbalizações do terapeuta que sugerem um julgamento desfavorável a diferentes tipos de ações ou verbalizações do cliente, tais como:

(1) discordância: Verbalizações nas quais o terapeuta discorda ou expressa julgamento desfavorável sobre ações, avaliações afirmações propostas ou características do cliente (sejam estas relatadas pelo cliente ou observadas pelo terapeuta). 
Ex: $>$ T: Eu não acho que seja assim. [REP]

$>\mathrm{T}$ : As coisas são muito mais simples do que você pinta. [REP]

(2) crítica: Verbalizações nas quais o terapeuta descreve falhas do cliente ou critica suas ações, características ou aparência.

Ex: $>\mathrm{T}$ : eu penso que você faz bem algumas coisas tais como supervisionar, monitorar

[APR], entretanto às vezes você entra em uma escalada de castigo, castigo, castigo. [REP]

(3) ironia: Comentários de qualquer natureza feitos em tom sarcástico ou hostil com relação ao cliente. Comentários do terapeuta que sugerem incredulidade a respeito de relatos do cliente sobre o que disse ou fez ou terapeuta ri de algo que o cliente disse ou fez.

Ex: $>\mathrm{T}$ : Você de fato pensa que sua mãe deveria deixá-lo vir para casa quando você quer? [REP]

$>\mathrm{T}$ : Eu vou pegar uma xícara de café. Eu estou perdido. [REP]

T: Você ta fumando com essa tosse? (sorrindo). [REP]

(4) ameaça: Verbalizações nas quais o terapeuta prevê conseqüências negativas ou aversivas para uma ação (ou pela não ação) do cliente em forma de ameaça.

Ex: $>\mathrm{T}$ : Você pode escolher fazer isto deste modo ou ser miserável o resto de sua vida. [REP]

$\mathrm{T}$ : Eu acho que a gente faz escolhas... você pode continuar fugindo de escolher uma profissão... há tantas pessoas que preferem, ser donas de casa e lavar as roupas do marido o resto da vida... [REP]

(5) paráfrase crítica: Paráfrase de verbalização anterior do cliente que explicita uma crítica ou aponta uma falta ou erro do cliente.

Ex: $>\mathrm{T}$ : Eles pegaram a recompensa mesmo quando eles não a tinham merecido? * pergunta apresentada em tom hostil após a cliente dizer que prometeu recompensa aos filhos após uma tarefa e que os filhos não cumpriram a tarefa e ela os recompensou. [REP]

$\mathrm{T}$ : Você quer dizer que você o deixa dormir em sua cama e ele a molha toda noite? (risada) [REP]

T: Você o deixou escolher seu próprio castigo? [REP]

(6) auto-revelações desafiadoras: Verbalizações nas quais o terapeuta relata sua experiência com relação a um evento do qual o cliente se queixa, sugerindo que sua atuação foi melhor que a do cliente ou que, se ele conseguiu solucionar o problema, o cliente também deveria conseguir.

Ex: $>\mathrm{T}$ : Quando eu resolvi sair da casa de meus pais eu tinha plena consciência de que eu deveria me sustentar, e não ficar esperando que meus pais me ajudassem. [REP]

(7) relato de sentimentos negativos: Relato de sentimentos que o cliente desperta no terapeuta que indicam que não gosta dele ou de algo que ele faça ou que não está sentindo-se bem com algum aspecto relativo ao comportamento do cliente.

Ex: $>\mathrm{T}$ : Eu vou continuar a atendê-lo por que para mim é um desafio, mas eu não gostei de você. [REP]

Ex: $>$ T: Eu fico muito irritado quando você fala comigo dessa forma. e quando isso acontece, a vontade que eu tenho é de te tratar da mesma forma. [REP]

(8) advertência: Verbalizações nas quais o terapeuta diz ao cliente que ele está impedindo o progresso terapêutico ou o andamento da sessão.

Ex: $>$ T: Eu quero ajudá-la, mas é impossível fazermos alguma coisa com tantos atrasos... hoje você chegou 40 minutos atrasada... o que nós podemos fazer em dez minutos? [REP]

Forma:

Verbalizações do tipo REPROVAÇÃO tipicamente apresentam a forma afirmativa (do tipo descritiva).

Podem assumir a forma de pergunta, com entonação sarcástica ou hostil. 
Podem também apresentar a forma imperativa quando implicam em um comando para mudança de comportamento dentro da sessão.

\section{Contexto:}

Precedente:.

Verbalizações de REPROVAÇÃO tipicamente são precedidas por verbalizações de descrição de eventos por parte do cliente.

Também é comum serem precedidas por verbalizações do terapeuta do tipo INFORMAÇÃO ou INTERPRETAÇÃO.

Subseqüente:

Podem ser seguidos por qualquer tipo de verbalização.

\section{Critérios de inclusão ou exclusão:}

(a) Quando uma reprovação foi acompanhada de descrição do evento que foi alvo da reprovação, será registrada unicamente a ocorrência da categoria REPROVAÇÃO. REPROVAÇÃO inclui todas as verbalizações que fornecem uma justificativa pela qual o terapeuta discorda ou de por que não funcionará determinada proposta do cliente.

(b) Quando uma análise do terapeuta apontar para conseqüências negativas ou aversivas da ação do cliente, sem nenhuma verbalização explícita de discordância ou reprovação, dê preferência à categoria INTERPRETAÇÃO.

(c) Diferentemente de aprovação que deve ser codificada apenas quando o relato do cliente não está em curso, um simples "não" proferido pelo terapeuta enquanto o cliente está falando é codificado REPROVAÇÃO se implicar em discordância do cliente.

(d) A correção de um engano do cliente, quando não realizada em tom hostil, não é categorizada como discordância, mas sim como INFORMAÇÃO.

(e) Verbalizações tais como "é mesmo?" ou "não acredito", quando não indicarem descrença, e sim interesse no relato do cliente, serão categorizadas como EMPATIA.

(f) Quando o terapeuta ri do relato de ações do cliente, não sugerindo ironia, mas sim interesse em seu relato (ele ri com o cliente, e não do cliente), categorizar EMPATIA.

(g) A previsão de conseqüências negativas ou aversivas para uma ação (ou não ação) do cliente só será considerada REPROVAÇÃO quando o terapeuta explicitar julgamento ou avaliação contrários à ação do cliente. A mera descrição de conseqüências aversivas a uma ação do cliente por parte do terapeuta, quando não indica ameaça e/ou não sugere um julgamento ou avaliação por parte do terapeuta será categorizada como INTERPRETAÇÃO. Na dúvida, categorize REPROVAÇÃO, que tem precedência sobre INTERPRETAÇÃO.

(h) Quando uma verbalização do tipo se... então for emitida em tom de ameaça, sugerindo que o cliente poderá sofrer conseqüências negativas ou aversivas caso realize (ou não) determinadas ações ou tarefas, será categorizada como REPROVAÇÃO.

\section{Outras verbalizações do Terapeuta - TOU (Outras Terapeuta)}

\section{Definição:}

Verbalizações do terapeuta não classificadas nas categorias anteriores.

Inclui também verbalizações do terapeuta relacionadas a acertos ocasionais de horários ou outras características do atendimento e também verbalizações do terapeuta ao cumprimentar o cliente em sua chegada ou partida, anúncios de interrupções ou comentários ocasionais alheios ao tema em discussão.

Ex: $>$ T: Quer uma balinha?

(1) Acertos ocasionais: Acertos ocasionais de horário e/ou local da sessão.

T: Então, a gente, na semana que vem faz a sessão na terça-feira, das três às quatro. [TOU] 
(2) Recuperação de assunto: descrição de diálogos ou assuntos anteriormente discutidos, somente em casos nos quais essa descrição foi solicitada pelo cliente devido a este ter perdido ou esquecido o rumo da discussão ou após alguma interrupção, para retomada do assunto.

C: Onde é que eu estava mesmo? [SOL]

T: Você estava falando sobre sua viagem de férias. [TOU].

T (após interrupção da sessão): Então, você estava me falando sobre o seu receio de prestar o vestibular. [TOU].

Forma:

(1) Qualquer formato.

\section{Contexto:}

Precedente:.

Indefinido

Subseqüente:

Indefinido.

Critérios de inclusão ou exclusão:

(a) Quando houver uma terceira pessoa envolvida na sessão, tal como em situações de orientação de pais, reuniões com cônjuge ou familiar, as falas do terapeuta dirigidas exclusivamente a esta terceira pessoa, ou nas quais havia dúvida sobre a quem a verbalização se dirigia (se apenas cliente, se apenas terceiro ou ambos) será categorizadas como OUTRAS. Já falas do terapeuta claramente dirigidas a ambos os participantes (cliente e terceiro) serão categorizadas na categoria correspondente.

\section{Registro Insuficiente -TIN (Insuficiente Terapeuta)}

\section{Definição:}

Verbalizações do terapeuta cujo conteúdo está ininteligível devido a problemas no áudio do filme, ou qualquer outro problema que impeça sua identificação e categorização.

\section{Forma:}

(1) Qualquer formato.

\section{Contexto:}

Precedente:

Indefinido

Subseqüente:

Indefinido.

Critérios de inclusão ou exclusão:

(a) Verbalizações serão categorizadas como ininteligíveis apenas quando não puderem ser identificadas mesmo depois de terem sido observadas por três vezes.

(b) Falas interrompidas do terapeuta cujo conteúdo identificável não é suficiente para a categorização em uma das categorias anteriores serão classificadas como INSUFICIENTE. 